UNIVERSIDADE DE SÃO PAULO

ESCOLA DE ENFERMAGEM

ENILDA MARIA DE SOUSA LARA

TRAJETÓRIA DE GESTANTES/PUÉRPERAS EM UMA UNIDADE DE CARDIOLOGIA FETAL DE UM HOSPITAL FILANTRÓPICO: UMA ABORDAGEM ETNOGRÁFICA

SÃO PAULO

2014 

ENILDA MARIA DE SOUSA LARA

\section{TRAJETÓRIA DE GESTANTES/PUÉRPERAS EM UMA UNIDADE DE CARDIOLOGIA FETAL DE UM HOSPITAL FILANTRÓPICO: UMA ABORDAGEM ETNOGRÁFICA}

Tese apresentada ao Programa de Pós-Graduação em Gerenciamento em Enfermagem da Escola de Enfermagem da Universidade de São Paulo para obtenção do título de Doutor em Ciências.

Área de concentração:

Fundamentos e Práticas de Gerenciamento em Enfermagem e em Saúde

Orientadora:

Prof $^{a}$. Dr ${ }^{a}$. Marta Maria Melleiro 
AUTORIZO A REPRODUÇÃO E DIVULGAÇÃO TOTAL OU PARCIAL DESTE TRABALHO, POR QUALQUER MEIO CONVENCIONAL OU ELETRÔNICO, PARA FINS DE ESTUDO E PESQUISA, DESDE QUE CITADAA FONTE.

Assinatura:

Data:

Catalogação na Publicação (CIP)

Biblioteca "Wanda de Aguiar Horta"

Escola de Enfermagem da Universidade de São Paulo

Lara, Enilda Maria de Sousa

Trajetória de gestantes/puérperas em uma unidade de cardiologia fetal de um hospital filantrópico: uma abordagem etnográfica / Enilda Maria de Sousa Lara. São Paulo, 2014. $244 \mathrm{p}$.

Tese (Doutorado) - Escola de Enfermagem da Universidade de São Paulo.

Orientadora: Prof. ${ }^{a}$ Dr. ${ }^{\text {a }}$ Marta Maria Melleiro

Área de concentração: Fundamentos e Práticas de Gerenciamento em Enfermagem e em Saúde.

1. Antropologia cultural e social 2. Gravidez de alto risco 3. Serviços de saúde - avaliação 4. Serviços de saúde - qualidade I. Título. 


\section{FOLHA DE APROVAÇÃO}

Nome: Enilda Maria de Sousa Lara

Titulo: Trajetória de gestantes/puérperas em uma Unidade de Cardiologia Fetal de um hospital filantrópico: uma abordagem etnográfica.

Tese apresentada ao Programa de Pós-Graduação em Gerenciamento em Enfermagem da Escola de Enfermagem da Universidade de São Paulo para obtenção do título de Doutor em Ciências.

Aprovado em:

\section{Banca Examinadora}

Prof. Dr.

Julgamento:

Prof. Dr.

Julgamento:

Prof. Dr.

Julgamento:

Prof. Dr.

Julgamento:

Prof. Dr.

Julgamento:
Instituição:

Assinatura:

Instituição:

Assinatura:

Instituição:

Assinatura:

Instituição:

Assinatura:

Instituição:

Assinatura: 

À minha mãe;

Aos meus fithos Gabriel, Bruno e Eduardo e ao meu neto Ramiro, por ser minha inspiração. 



\section{AGRADECIMENTOS}

À minha acolhedora orientadora Prof ${ }^{a}$ Dra. Marta Melleiro, por sua paciência e sabedoria;

Às professoras $\mathrm{Dr}^{\text {as }}$. Dulce Gualda e Daisy Tronchin pelas importantes contribuições durante o exame de qualificação;

À Associação do Sanatório Sírio Hospital do Coração que me proporcionou a realização deste trabalho;

Às gestantes/puérperas, participantes deste estudo com as quais vivenciei fortes emoções;

À equipe de Unidade de Cardiologia Fetal, em especial Dra Simone Pedra e a enfermeira Ana Lucia Abrahão;

Ao Diretor do Instituto de Ensino e Pesquisa do HCor, Dr. Otávio Berwanger, que me estimulou a aprender Pesquisa Qualitativa;

Aos meus queridos gestores do HCor - companheiros de muitos projetos para melhoria do SUS, Dr Armando De Negri Filho, Gestor do LIGRESS/HCor e a Superintendente de Qualidade e Responsabilidade Social Dra. Bernardete Weber;

Aos meus colegas do Núcleo de Pesquisa Qualitativa do LIGRESS/HCor por suas incansáveis contribuições;

As minhas amigas pessoais, Alessandra Akiko Kodama, Claudia Jesus de Oliveira, Cleusa Enck, Erica Suzumura, Glaucia Lara, Mabel Figueiró , Natália Figueiró e Patrícia Pandolfo, pelo apoio incondicional;

Às minhas generosas professoras de português Kassia Carvalho e Thais Weigert pela incansável atenção. 

Lara EMS. Trajetória de gestantes /puérperas em uma unidade de cardiologia fetal de um hospital filantrópico: uma abordagem etnográfica. [Tese] São Paulo (SP): Escola de Enfermagem da USP; 2014.

\section{RESUMO}

Introdução: A vivência e a lógica do usuário acerca do atendimento recebido nos serviços de saúde são imprescindíveis para reorganização e implementação das ações de saúde, representando, assim, uma das maneiras de se avaliar a qualidade e a segurança nessas instituições. Objetivo: Compreender a experiência de gestantes/puérperas acerca do atendimento recebido na Unidade de Cardiologia Fetal de um Hospital Filantrópico. Caminho metodológico: Trata-se de um estudo qualitativo, de cunho etnográfico, cujo cenário cultural foi a Unidade de Cardiologia Fetal do Hospital do Coração de São Paulo. As participantes foram oito gestantes/puérperas atendidas na referida instituição de saúde. A coleta de dados foi realizada, após anuência dos Comitês de Ética, por meio da observação participante e da entrevista, no período de agosto de 2012 a agosto de 2013. Os dados foram apresentados na forma de narrativa e analisados de acordo com Janesick. Achados: Das narrativas emergiram doze categorias culturais, a saber: A descoberta da gravidez não planejada; $O$ enfrentamento do diagnóstico de cardiopatia congênita; A esperança na sobrevivência do bebê - Mudança no estilo de vida; O apoio de familiares e de amigos; $O$ acesso à alta complexidade: para onde ir? A chegada a São Paulo: o medo do desconhecido; Os avanços tecnológicos versus gestação de alto risco; $O$ apego à religiosidade/espiritualidade; $\mathrm{O}$ apoio recebido do terceiro setor/rede social; $O$ fortalecimento do vínculo familiar frente às dificuldades advindas com a trajetória da doença; A luta, o luto e as conquistas e A avaliação da Unidade de Cardiologia Fetal. Para a análise interpretativa foi adotado o referencial da Trajetória da Doença Crônica, que tem por pressupostos a ruptura biográfica, o impacto do tratamento na vida diária e no cuidado à saúde e adaptação e o manejo da doença, proposto por Michael Bury. Considerações finais: Esta investigação permitiu ter uma visão compreensiva da percepção das gestantes/puérperas com relação à Unidade de Cardiologia Fetal, interpretar e incorporar suas vivências, de modo a qualificar o cuidado e, consequentemente, o cenário deste estudo.

Descritores: Antropologia cultural, Gestação de alto risco, Qualidade de serviços de saúde, Avaliação de serviços de saúde. 

Lara EMS. Trajectory of pregnant women /puerpera in a fetal cardiology unit of a philanthropic hospital: an ethnographic approach. [Thesis] são paulo (SP): nursing school of the university of São Paulo; 2014.

\section{ABSTRACT}

Introduction: The experience and logic of the health service user about the care received are essential for the reorganization and implementation of health actions, thus representing one way to assess the quality and safety in these services. Objective: To understand the experience of pregnant women/puerpera about the care received in a Fetal Cardiology Unit of a Philanthropic Hospital. Methods: This is a qualitative study using an ethnographic approach, focusing on the cultural scenario of the Fetal Cardiology Unit of the Hospital for the Heart of Sao Paulo. The participants were eight pregnant women/puerpera who received care in this Fetal Cardiology Unit. The data collection was carried out after the Ethics Committees had given their consent, through participant observation and interview, from August 2012 to August 2013. The data were presented in narratives and analyzed according to Janesick. Findings: The following twelve cultural categories emerged from the narratives: The discovery of an unexpected pregnancy; Facing the diagnosis of a congenital heart disease; Hope in the survival of the baby - Change in lifestyle; Support of family and friends; Access to high complexity care: Where to go? Arriving at Sao Paulo: fear of the unknown; Advances in technology versus high risk pregnancy; Attachment to religiosity/spirituality; Support of the third sector/social network; Strengthening family relationships to face difficulties arising from the disease trajectory; The fight, the grief and the achievements; and Assessing the Fetal Cardiology Unit. The Chronic IIIness Trajectory framework was used for the interpretative analysis, which is based on the assumptions of biographical disruption, the impact of treatment on everyday life and own health care, and adaptation and disease management, proposed by Michael Bury. Final considerations: This study provided a comprehensive view of the perception of the pregnant women/puerpera regarding the Fetal Cardiology Unit; the interpretation and incorporation of their experiences make it possible to qualify the health care, and thus the scenario of this study.

Descriptors: Cultural anthropology, High-risk pregnancy, Quality of health care, Assessment of health services 

Lara EMS. Trayectoria de gestantes /puérperas en una unidad de cardiología fetal de un hospital filantrópico: un abordaje etnográfico. [Tesis] São Paulo (SP): Escuela de Enfermería de la Universidad de São Paulo; 2014.

\section{RESUMEN}

Introducción: La vivencia y la lógica del usuario acerca de la atención recibida en los servicios de salud son imprescindibles para la reorganización e implementación de las acciones de salud, por lo que representan una de las maneras de evaluar la calidad y la seguridad en esas instituciones. Objetivo: Comprender la experiencia de gestantes/puérperas acerca de la atención recibida en la Unidad de Cardiología Fetal de un Hospital Filantrópico. Camino metodológico: Se trata de un estudio cualitativo, etnográfico, cuyo escenario cultural fue la Unidad de Cardiología Fetal del Hospital del Corazón de São Paulo. Las participantes fueron ocho gestantes/puérperas atendidas en la referida institución de salud. La recopilación de datos fue realizada después de la aprobación de los Comités de Ética, a través de la observación participante y la entrevista, en el período de agosto de 2012 a agosto de 2013. Los datos fueron presentados en forma de narrativa y analizados según Janesick. Resultados: $\mathrm{De}$ las narrativas emergieron las siguientes doce categorías culturales: $\mathrm{EI}$ descubrimiento del embarazo no planeado; El enfrentamiento del diagnóstico de cardiopatía congénita; La esperanza de la sobrevivencia del bebé - Cambio en el estilo de vida; El apoyo de parientes y amigos; El acceso a la alta complejidad: ¿adónde ir? La llegada a São Paulo: el miedo del desconocido; Los avances tecnológicos versus gestación de alto riesgo; El apego a la religiosidad/espiritualidad; El apoyo recibido del tercer sector/red social; El fortalecimiento del vínculo familiar frente a las dificultades derivadas de la trayectoria de la enfermedad; La lucha, el luto y los logros, y La evaluación de la Unidad de Cardiología Fetal. Para el análisis interpretativo fue adoptado el referencial de la Trayectoria de la Enfermedad Crónica, que se basa en los supuestos de la ruptura biográfica, el impacto del tratamiento en la vida diaria y en el cuidado de la salud, y adaptación y el manejo de la enfermedad, propuesto por Michael Bury. Consideraciones finales: Esta investigación permitió tener una visión comprensiva de la percepción de las gestantes/puérperas acerca de la Unidad de Cardiología Fetal, interpretar e incorporar sus vivencias, para cualificar el cuidado $y$, consecuentemente, el escenario de este estudio.

Descriptores: Antropología cultural, Embarazo de alto riesgo, Calidad de servicios de salud, Evaluación de servicios de salud. 



\section{LISTA DE ILUSTRAÇÕES}

Figura 1 - Esquema demonstrativo dos nove capítulos em quatro eixos. São Paulo, 2014. .

Figura 2 - Esquema demonstrativo da trajetória da doença crônica proposta por Michael Bury (1997).

Figura 3 - Esquema demonstrativo da trajetória de gestantes/puérperas de bebês cardiopatas segundo o referencial de Michael Bury. (São

Paulo, 2014). 



\section{LISTA DE SIGLAS}

AAS - Ácido acetilsalicílico

ACTC - Associação de Assistência à Criança Cardiopata

AME - Ambulatório Médico de Especialidades

CLT - Consolidação das Leis do Trabalho

CNRAC - Central Nacional de Regulação da Alta Complexidade

CPAP - Pressão positiva contínua na via aérea

DATASUS - Departamento de Informática do SUS

DERAC-DF - Departamento de Regulação, Avaliação e Controle do

Distrito Federal

DIU - Dispositivo Intra-Uterino

EEUSP - Escola de Enfermagem da Universidade de São Paulo

EMTN - Equipe Multiprofissional de Terapia Nutricional

GM - Gabinete do Ministro

HC - Hospital das Clínicas

HCor - Hospital do Coração

HVE - Hipertrofia ventricular esquerda

IBFAN - International Baby Food Action Network

IEP - Instituto de Ensino e Pesquisa

IML - Instituto Médico Legal

$\mathrm{JCl}$ - Joint Commission International

LIGRESS - Laboratório de Inovação em Planejamento, Gestão,

Avaliação e Regulação de Políticas, Sistemas, Redes e Serviços de Saúde 

MG - Minas Gerais

MS - Mato Grosso do Sul

MS - Ministério da Saúde

MT- Mato Grosso

NPQ - Núcleo de Pesquisa Qualitativa

OMS - Organização Mundial da Saúde

ONG - Organização não Governamental

ONU - Organização das Nações Unidas

PAE - Pressão do átrio esquerdo

PAP - Pressão da artéria pulmonar

PB - Paraíba

PPGEn - Programa de Pós-Graduação em Gerenciamento em

Enfermagem

PROADI-SUS - Projeto de Apoio ao Desenvolvimento Institucional do Sistema Único de Saúde

PVC - Pressão venosa central

RAS - Rede de Atenção à Saúde

RN - Recém Nascido

RS - Rio Grande do Sul

SHCE - Síndrome de Hipoplasia do Coração Esquerdo

SP - São Paulo

SUS - Sistema Único de Saúde

TCLE - Termo de Consentimento Livre e Esclarecido

UBS - Unidade Básica de Saúde

UNICEF - United Nations International Children's Emergency Fund UTI - Unidade de tratamento intensivo 



\section{SUMÁRIO}

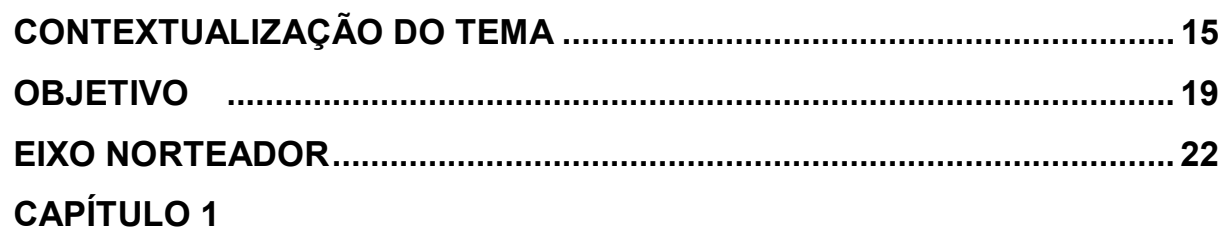

ASSISTÊNCIA MATERNO-INFANTIL NO BRASIL ...................................... 24

1.1 Políticas de saúde, qualidade e segurança ................................ 24

1.2 A assistência cardiofetal ............................................................... 28

CAPÍTULO 2

ACESSO À TECNOLOGIA E AOS SERVIÇOS DE SAÚDE DE ALTA COMPLEXIDADE NA ÁREA MATERNO-INFANTIL ..................32

CAPÍTULO 3

REFERENCIAIS TEÓRICO- METODOLÓGICOS......................................... 39

3.1 Opção pela pesquisa qualitativa ................................................ 39

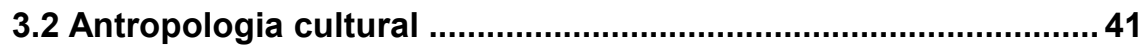

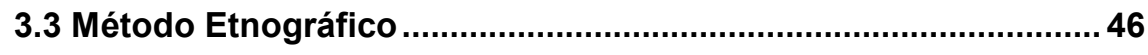

CAPÍTULO 4

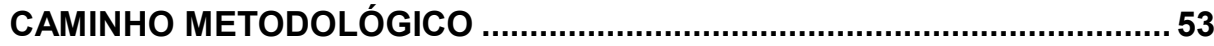

4.1 Contexto da investigação ............................................................53

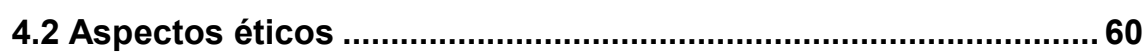

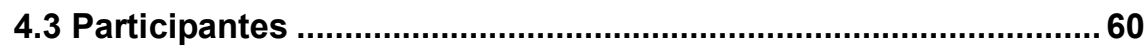

4.4 Coleta dos dados: a observação participante e a entrevista ...... 61

4.4.1 Observação participante ................................................... 61

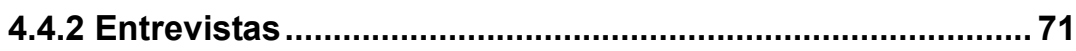

4.5 A organização e a análise dos dados ....................................... 73

CAPÍTULO 5

NARRATIVAS, VIVÊNCIAS E SENTIMENTOS DAS PARTICIPANTES .......75

CAPÍTULO 6

AS CATEGORIAS CULTURAIS ORIUNDAS DAS NARRATIVAS ...............166

6.1 A descoberta da gravidez não planejada .................................... 169

6.2 O enfrentamento do diagnóstico de cardiopatia congênita .... 170

6.3 A esperança na sobrevivência do bebê - Mudança no estilo de vida......................................................................................... 175

6.40 apoio de familiares e de amigos .......................................... 176

6.50 acesso à alta complexidade: para onde ir? ............................ 178

6.6 A chegada a São Paulo: medo do desconhecido ...................... 180 

6.7 Os avanços da tecnológicos versus gestação de alto risco ... 182

6.80 apego à religiosidade/espiritualidade .................................. 185

6.90 apoio recebido pelo terceiro setor/ rede Social .................... 187

6.100 fortalecimento do vínculo familiar frente as dificuldade advindas com a trajetória da doença .................................. 190

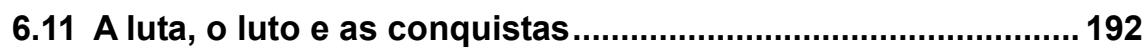

6.12 A avaliação da Unidade de Cardiologia Fetal por parte das

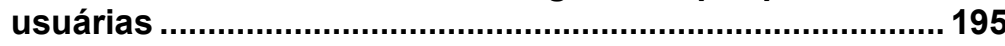

CAPÍTULO 7

ANÁLISE INTERPRETATIVA À LUZ REFERENCIAL TEÓRICO 201

CAPÍTULO 8

AS INTERVENÇÕES PROPOSTAS À UNIDADE DE CARDIOLOGIA FETAL

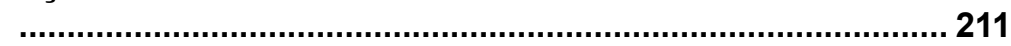

CAPÍTULO 9

AS PERSPECTIVAS E OS DESAFIOS FRENTE ÀS POLÍTICAS DE SAÚDE

218

REFERÊNCIAS

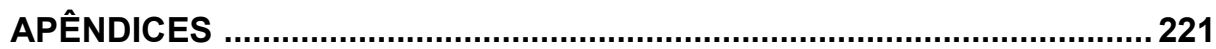

ANEXOS 

CONTEXTUALIZAÇÃO DO TEMA

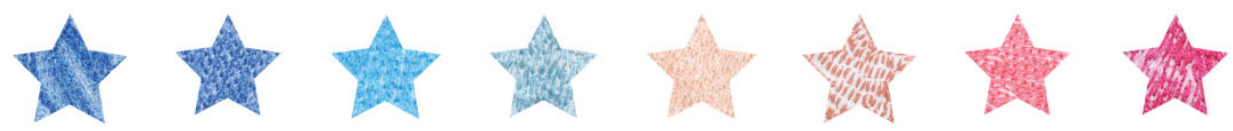



A formação no curso de graduação em nutrição, no Instituto Metodista de Educação e Cultura, em Porto Alegre (RS), concluída em 1988, proporcionou-me o envolvimento em diversos cenários da área de atuação do nutricionista, mas minha maior identificação e inserção ocorreram no contexto materno-infantil, provavelmente, devido ao nascimento de dois de meus filhos nesse período.

Assim, minha primeira atividade profissional como nutricionista foi em um serviço de pediatria, de um hospital público em ljuí (RS), onde tive a oportunidade de participar da Organização Não Governamental Rede Internacional em Defesa do Direito de Amamentar (IBFAN), na qual atuei por 20 anos. Nessa ocasião, organizei cursos e seminários com muitos profissionais que eram referência na área e trabalhei em projetos financiados pelo Fundo das Nações Unidas para a Infância (UNICEF).

Em 1990, como Coordenadora da Unidade de Nutrição de outro hospital público, em Camaquã (RS), participei da implementação de uma nova maternidade nesse hospital e, cada vez mais envolvida, com a saúde materno-infantil fui convidada a participar de programas de rádio, na referida cidade, sobre essa temática. Nasce meu terceiro filho.

Posteriormente, em 1993, fui contratada pela Maternidade do Hospital Moinhos de Vento, em Porto Alegre. Nessa instituição filantrópica, de caráter privado, atuava nas Unidades de Terapia Intensiva Neonatal e Pediátrica e na Clínica Obstétrica, onde ministrava cursos para gestantes sobre aleitamento materno, alimentação da gestante e nutriz e alimentação das crianças de 0 a 2 anos de vida.

Como membro da Rede IBFAN fui convidada a participar do projeto de pesquisa intitulado "Influência da técnica de amamentação nas frequências de aleitamento materno exclusivo e lesões mamilares no primeiro mês de lactação". Esse projeto tornouse minha dissertação de mestrado, que foi defendida, em 2005, no Programa de Pós-Graduação em Pediatria, na Universidade Federal 
do Rio Grande do Sul. A referida pesquisa proporcionou-me a possibilidade de entrar em contato com outros profissionais de saúde, que desenvolviam pesquisas na abordagem qualitativa, delineando-se, desse modo, meu interesse por esse tipo de investigação.

Na década de 2000, projetos de extensão à comunidade foram desenvolvidos no Hospital Moinhos de Vento, dentre eles a estruturação de duas equipes da Estratégia Saúde da Família, no Arquipélago das llhas de Porto Alegre, por meio de uma parceria com a Prefeitura Municipal. Nossa equipe trabalhava intensamente nas comunidades, realizando visitas domiciliares, muitas vezes de barcos, devido à falta de acesso das famílias às unidades de saúde. Era um trabalho articulado em rede com lideranças/ serviços oferecidos nas citadas llhas (educação, segurança pública, cooperativas de reciclagem e trabalho com o meio ambiente).

Nesse período, além de nutricionista social na área de filantropia, também atuei como professora substituta do Departamento de Medicina Social, da Universidade Federal do Rio Grande do Sul; acompanhava alunos do curso de nutrição para a realização de trabalhos em ambulatórios e para a avaliação nutricional das crianças que participavam de programas de transferência de renda. Também coordenei uma atividade com um grupo de gestantes/puérperas - encontros semanais para trabalhar o programa do Ministério da Saúde "Dez passos para uma alimentação saudável: guia alimentar para crianças menores de dois anos".

Dessa maneira, atuei nos dois extremos dos grupos sociais e: convivia com a vulnerabilidade das comunidades e ao mesmo tempo trabalhava com gestantes de classes econômicas mais favorecidas, como professora do curso de gestantes no espaço qualidade de vida do Hospital Moinhos de Vento. Em ambos os cenários, eu percebia que havia semelhantes inquietações e expectativas, por parte das 
gestantes, frente ao ciclo gravídico-puerperal e procurava atender essas necessidades.

No final da década de 2000, especificamente em 2008, um novo desafio apresentava-se: integrar a equipe da Filantropia do Hospital do Coração de São Paulo - HCor, hospital filantrópico acreditado pela Joint Commission International - $\mathrm{JCl}$, conforme legislação vigente participa do Programa de Apoio ao Desenvolvimento Institucional do Sistema Único de Saúde PROADI-SUS. O HCor é considerado pelo Ministério da Saúde um dos seis hospitais de excelência do país, assim como o Hospital Moinhos de Vento, com isenção fiscal e a obrigatoriedade de devolver esses recursos em ações de interesse do SUS.

Nesse cenário, passei a atuar como Coordenadora dos Projetos de Filantropia do HCor, desenvolvidos no âmbito do Instituto de Ensino e Pesquisa (IEP) e do Laboratório de Inovação em Planejamento, Gestão, Avaliação e Regulação de Políticas, Sistemas, Redes e Serviços de Saúde (LIGRESS).

Considerando a demanda do IEP para o desenvolvimento de investigações na abordagem qualitativa, o LIGRESS criou o Núcleo de Pesquisa Qualitativa (NPQ). Devido ao meu interesse em desenvolver estudos na referida metodologia, assumi a coordenação do NPQ, o que me levou ao encontro de professoras da Escola de Enfermagem, da Universidade de São Paulo (EEUSP), reconhecidas como referência na área. A partir desse contato e tendo em vista a minha trajetória profissional na área materno-infantil, surgiu a oportunidade de inserir-me no programa de Pós-Graduação da EEUSP.

Dessa forma, em 2010, fui aprovada no processo seletivo do Programa de Pós-Graduação em Gerenciamento em Enfermagem (PPGEn), para o curso de doutorado, optando por desenvolver um estudo pautado nos referenciais teórico-metodológicos da Antropologia e da Etnografia, articulando-o com um dos projetos da Filantropia desenvolvidos na Unidade de Cardiologia Fetal do HCor, 
com o propósito de conhecer a percepção das gestantes/puérperas usuárias desse serviço.

Minha inserção na equipe da Unidade Cardiofetal foi facilitada pelo relacionamento construído com a equipe multiprofissional, o qual foi fortalecido durante o desenvolvimento desta pesquisa, ao participar das reuniões de equipe e acompanhar os atendimentos das gestantes/puérperas e o desenvolvimento das atividades desse serviço.

Cabe salientar que uma das metas do referido serviço é a promoção da satisfação de seus usuários, a qual é mensurada por meio da qualidade do serviço prestado, considerando os parâmetros de acreditação propostos pela $\mathrm{JCl}$.

Por conseguinte, a proposta deste estudo foi compreender, por meio da escuta, da observação e da participação, em uma abordagem qualitativa, a percepção que as gestantes e puérperas de bebês com diagnóstico de cardiopatia congênita têm do serviço de cardiologia fetal da Associação do Sanatório Sírio - Hospital do Coração de São Paulo, com o intuito de interpretar os dados encontrados, visando contribuir para sua incorporação não somente no âmbito do HCor, mas no próprio SUS. 
OBJETIVO

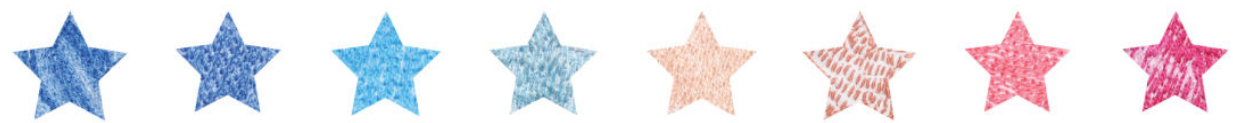



Compreender a experiência de gestantes/puérperas acerca do atendimento recebido na Unidade de Cardiologia Fetal de um Hospital Filantrópico. 

EIXO NORTEADOR

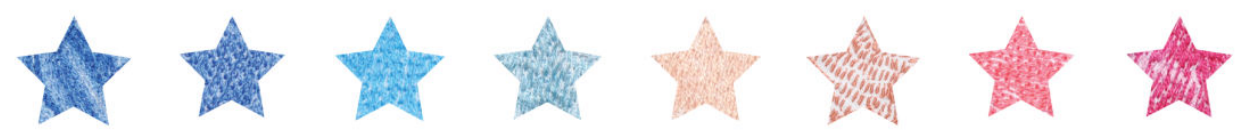



A figura 1 demonstra a inserção dos nove capítulos desta tese em quatro eixos: Políticas públicas, Qualidade e segurança e avaliação do serviço de saúde, Pesquisa qualitativa e Viabilidade.

Figura 1 - Esquema demonstrativo dos nove capítulos em quatro eixos. São Paulo, 2014.

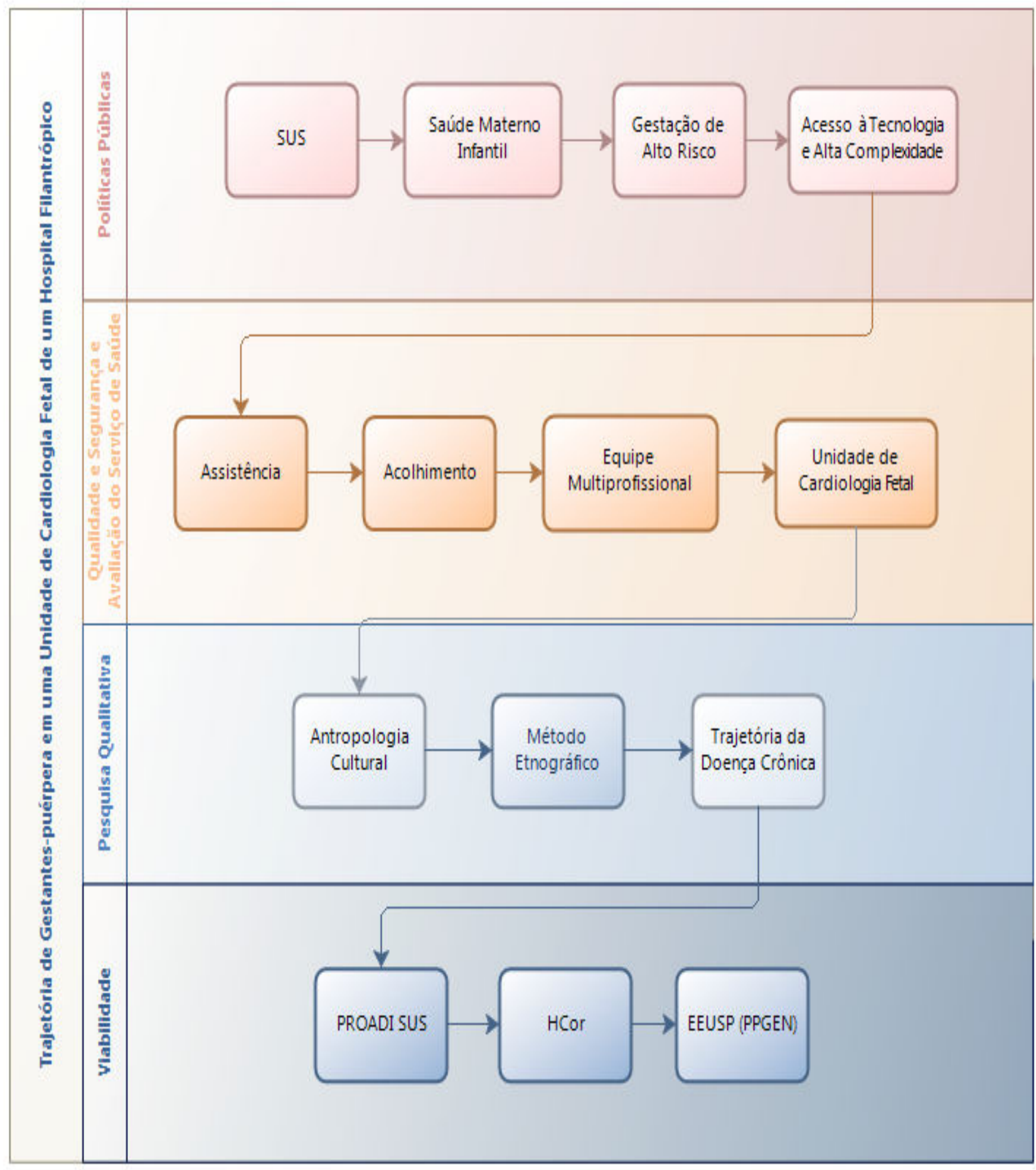





\section{CAPÍTULO 1}

ASSISTÊNCIA MATERNO-INFANTIL NO BRASIL

$\checkmark \quad$ Políticas de saúde, qualidade e segurança

$\checkmark \quad$ Assistência cardiofetal

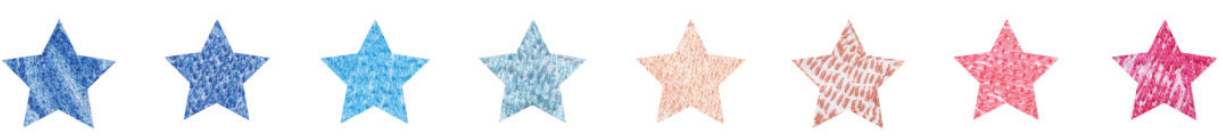





\subsection{Políticas de saúde, qualidade e segurança}

As mudanças econômicas ocorridas no Brasil, nos últimos 30 anos, acarretaram sucessivas transformações nos determinantes sociais das doenças e na organização dos serviços de saúde. Especificamente na área materno-infantil foram identificadas melhorias, reveladas por meio de indicadores de saúde.

A Organização das Nações Unidas (ONU), ao analisar os maiores problemas mundiais, estabeleceu Oito Objetivos do Milênio, que devem ser atingidos por todos os países até 2015, entre essas metas destacamos para este estudo: a Meta do Milênio número $4 \mathrm{e}$ a número 5 que são respectivamente: reduzir a mortalidade infantil e melhorar a saúde das gestantes ${ }^{1}$.

A taxa de mortalidade infantil no Brasil caiu $77 \%$ em 22 anos, portanto esta meta foi alcançada o país reduziu seu índice de 62 mortes a cada mil nascimentos, em 1990, para 14 mortes por mil nascidos vivos em 2012, cabe salientar, que esse índice, é considerado como erradicação pela ONU, entretanto, as mortes no primeiro ano de vida representam $90 \%$ da mortalidade no grupo etário de 0 a 4 anos e as mortes neonatais ( 0 a 28 dias) responsáveis por $68 \%$ das mortes infantis. As cardiopatias congênitas colaboram, sensivelmente com estes índices. Com relação aos indicadores maternos, observou-se que taxa total de fecundidade reduziu marcadamente de 6,3 filhos por mulher no inicio dos anos 1960 para 1,8 por mulher entre 2002 e $2006^{2}$.

A razão oficial de mortalidade materna mantém-se estável nos últimos 15 anos, ao redor de 64 mortes por 100.000 nascidos vivos ${ }^{3}$. O progresso na razão de mortalidade materna é difícil de ser avaliado, uma vez que a tendência temporal do indicador vem sendo afetado por melhorias nas estatísticas vitais, mas há evidências de diminuição nas razões de óbitos maternos nos últimos 30 anos. Entretanto, a Meta do Milênio número 5 (redução de três quartos da 
mortalidade materna entre 1990 e 2015) possivelmente não será alcançada. Apesar de muitos progressos, desafios importantes ainda persistem, incluindo a medicalização abusiva, altos índices de partos cesáreos, mortes maternas causados por abortos inseguros e alta frequência de nascimento pré-termo ${ }^{2}$.

Todavia, os indicadores de saúde mostram que há, ainda, disparidades entre as diferentes regiões do país. No entanto, as desigualdades regionais e socioeconômicas nas coberturas de intervenções, no estado nutricional e em outros indicadores de saúde vem diminuindo marcadamente. Os principais fatores que contribuíram para tais avanços incluem melhorias nos determinantes sociais (pobreza, educação, urbanização e fecundidade), intervenções fora do setor saúde (transferência condicional de renda, abastecimento de água e saneamento) e a criação de um sistema nacional de saúde unificado com territorialização da atenção primária, dirigido à melhoria do acesso à atenção de saúde da população mais necessitada, além de programas centrados em doenças específicas ${ }^{2}$.

No que tange aos serviços especializados em atendimento às gestantes de alto risco o Ministério da Saúde publicou a Portaria $n^{\circ}$ 1.020, que institui as diretrizes para a organização da Atenção à Saúde na Gestação de Alto Risco, e define os critérios para a implantação e habilitação dos serviços de referência à Atenção à Saúde na Gestação de Alto Risco ${ }^{4}$.

Cabe destacar que a Gestação de Alto Risco é "aquela na qual a vida ou a saúde da mãe,do feto ou do recém-nascido têm maiores chances de serem atingidas que as da média da população considerada"4.

A Portaria $n^{\circ} 1.020$, do Ministério da Saúde, define sobretudo a necessidade do acolhimento das gestantes como o "processo constitutivo das práticas que implicam a responsabilização da equipe de saúde pela mulher e pelo recém-nascido, desde a chegada ao estabelecimento de saúde até a sua alta, garantindo bem estar e 
inclusão". Discorre, ainda, que a Atenção à Saúde na Gestação de Alto Risco deverá observar, entre outros, os seguintes princípios e diretrizes: universalidade, equidade e integralidade; humanização da atenção, ofertando atenção adequada, em tempo oportuno, na gestação, de acordo com suas necessidades e condições clínicas; acolhimento com avaliação de risco e vulnerabilidade em todos os pontos de atenção; regionalização da atenção à saúde, com articulação entre os diversos pontos de atenção da Rede de Atenção à Saúde (RAS), conforme pactuação local; atenção multiprofissional e interdisciplinar, com práticas clínicas compartilhadas e baseadas em evidências; regulação de acesso;e controle social ${ }^{4}$.

No contexto da atenção obstétrica e neonatal, a temática segurança do paciente, também, tem sido objeto de atenção nos últimos anos, em especial no que se refere à segurança da mulher na sala de parto e no puerpério. Devido ao desenvolvimento científico e aos avanços tecnológicos temos assistido as mudanças que se fundamentam no direito à humanização da assistência obstétrica e neonatal, como primeira condição, para o atendimento seguro ao parto e puerpério ${ }^{5}$.

A Rede Cegonha é outra estratégia governamental criada com a intenção de concretizar um modelo de atenção ao parto e ao nascimento que vem sendo discutido e construído no País desde os anos 90 , com base no pioneirismo e na experiência de trabalhadores da saúde, parteiras, doulas, acadêmicos, antropólogos, sociólogos, gestores, formuladores de políticas públicas, mulheres ativistas e instituições de saúde, entre muitos outros. Essa estratégia procura avançar no sentido de garantir o acesso e a melhoria da qualidade do pré-natal, a vinculação da gestante à unidade de referência para o parto, incorporação das boas práticas na atenção ao parto e nascimento, o direito ao acompanhamento de livre escolha da mulher durante o trabalho de parto, parto e puerpério e garantia de seguimento da puérpera e da criança até o segundo ano de vida, propiciando a vivência dessas experiências com segurança, 
dignidade e o respeito pelos serviços de saúde às dimensões social, afetiva e sexual do parto e nascimento e às singularidades culturais, étnicas e raciais ${ }^{6}$.

Entretanto, a qualidade dos serviços de saúde ofertados às mulheres ainda não contempla os aspectos supracitados, sendo pauta constante nas agendas dos gestores desses serviços, visando a implementação de ações que consolide tal estratégia.

Nessa direção, a Organização Mundial da Saúde (OMS), desde a década de 90 vem preconizando que para o alcance da qualidade e segurança nos serviços de saúde é imperativo que haja: alto grau de competência profissional, a eficiência na utilização dos recursos, mínimos riscos e alto grau de satisfação dos pacientes e efeito favorável na saúde.

$\mathrm{Na}$ contemporaneidade, a qualidade e a segurança nos serviços de saúde, passaram a ser elementos norteadores dos pressupostos filosóficos e metodológicos que devem reger as organizações, de natureza pública ou privada. A qualidade e segurança dos pacientes devem atender as exigências de melhor assistência demandada por uma população de usuários com maior percepção crítica, diante do panorama mundial de transformações econômicas, sociais e culturais ${ }^{7}$.

Desse modo, o atendimento dessas exigências implica processo gradual e diferenciado, devendo ser constantemente avaliado, incluindo a reconfiguração das relações entre profissionais e pacientes e entre demanda e oferta, podendo ser afetado, também, pela variação dos níveis de desigualdade social em saúde.

No mundo, milhões de pessoas sofrem lesões desabilitantes e mortes decorrentes de práticas em saúde que são consideradas inseguras. A Health Foundation acredita que não será possível melhorar a qualidade dos serviços de saúde e a segurança do paciente até que compreendamos claramente, antes de mais nada, como determinar se o cuidado é seguro. 
Em The measurement and monitoring of safety, o professor Charles Vicent e seus colaboradores do Imperial College London sublinham cinco dimensões que devem ser incluídas em qualquer abordagem de monitoramento de segurança, a fim de obter um quadro abrangente e equilibrado da segurança numa organização de saúde, são eles: Danos passados: incluindo indicadores tanto psicológicos como físicos; Confiabilidade- definida como o funcionamento sem falhas ao longo do tempo e aplicada a indicadores do comportamento, dos processos e dos sistemas; Sensibilidade às operações: as informações e a capacidade de monitorar a segurança hora a hora ou dia a dia; Antecipação e preparação: a capacidade da organização de antecipar os problemas e de estar preparada para a sua ocorrência; Integração e aprendizado: a capacidade de reagir e melhorar a partir das informações de segurança ${ }^{8}$.

Salientamos que tais dimensões são extremamente demandadas na assistência à Gestação de Alto Risco, onde o binômio mãe e filho encontram-se em maior grau de vulnerabilidade, devido ao fato de estarem acometidos por graves patologias.

Portanto, a qualidade e a segurança nos serviços de saúde são enfocadas a luz da assistência de alta complexidade, necessária para o atendimento de crianças cardiopatas.

\subsection{A assistência cardiofetal}

As cardiopatias congênitas são as mais frequentes ao nascer, com uma incidência aproximada de oito por 1000 nascidos. Dentre os oito afetados, três apresentam anomalias de conexão, que representam as mais severas formas de cardiopatias congênitas ${ }^{9}$.

A cardiopatia congênita é considerada qualquer anormalidade na estrutura ou função do coração, que surge nas primeiras oito semanas de gestação quando se forma o coração do bebê. Ocorre por uma alteração no desenvolvimento embrionário da estrutura 
cardíaca, podendo ser descoberto no nascimento ou anos mais tarde. É o defeito congênito mais comum e uma das principais causas de óbitos relacionadas às malformações congênitas ${ }^{9}$.

Nesse cenário, o diagnóstico precoce é fundamental e na prática clínica, a ecocardiografia fetal tem trazido evidentes benefícios para o tratamento das cardiopatias congênitas no pré e no pós-natal.

A cardiologia pediátrica contemporânea transformou-se radicalmente a partir do advento da ecocardiografia, do cateterismo intervencionista e do avanço das técnicas cirúrgicas ${ }^{10}$.

Conduto, foi a possibilidade de identificar precocemente a presença de malformações cardíacas, ainda, durante o desenvolvimento in utero, por meio da ecocardiografia fetal, que constituiu a pedra angular da trajetória da ciência cardiológica em direção ao futuro. Essa técnica de concepção aparentemente simples, viabilizou o estabelecimento de condutas salvadoras para o concepto cardiopata, antes e logo após o nascimento ${ }^{10}$.

Nesse contexto, uma das cardiopatias mais severas é a denominada de Síndrome de Hipoplasia do Coração Esquerdo (SHCE). Essa síndrome caracteriza-se pelo hipodesenvolvimento das estruturas cardíacas esquerdas, sendo que a perfusão coronária é dependente do fluxo do canal arterial, e o fluxo pulmonar e sistêmico é dependente do ventrículo direito ${ }^{11}$.

As câmeras direitas apresentam-se bem aumentadas, sendo que o átrio direito é dilatado e hipertrófico. O ventrículo direito, também, é dilatado e difusamente hipertrofiado. O canal arterial está localizado à esquerda na maioria dos casos e geralmente está dilatado.

O átrio esquerdo é hipoplásico, e a valva mitral pode ser estenótica ou atrésica. O ventrículo esquerdo é hipoplásico e apresenta áreas de fibroelastose endocárdica.

A aorta ascendente apresenta-se menor e mais estreita no nível da junção do arco aórtico com artéria inominada. 
As anormalidades cromossômicas mais frequentes que possuem a SHCE são a Síndrome de Turner e as Trissomias 13,18 e 21. Outras anomalias extracardíacas podem estar presentes em torno de $10 \%$ dos casos e compreendem Hérnia diafragmática, Agnesia de corpo caloso, microcefalia, entre outras.

O quadro clínico característico da SHCE consiste em cianose discreta, desconforto respiratório e taquicardia. Rapidamente, aparecem sintomas e sinais de insuficiência cardíaca congestiva e sinais de baixo débito sistêmico ${ }^{12}$.

A SHCE corresponde a quarta cardiopatia mais frequente na idade neonatal, com incidência de 7\% a 9\% (1:4000 a 6000 nascidos vivos) e mortalidade de $25 \%$ na primeira semana de vida. Há evidências que suportam o conceito que fatores genéticos $e$ ambientais contribuem para o desenvolvimento de doenças do coração esquerdo ${ }^{11,13,14}$.

Em bebês com SHCE, o lado esquerdo do coração é subdesenvolvido e não pode bombear sangue suficiente para atender às necessidades do corpo ${ }^{13}$.

O ecocardiograma é fundamental na avaliação de pacientes com SHCE e continua após o primeiro estágio a ser a principal técnica de monitoramento dessa população de crianças cardiopatas $^{15}$.

A SHCE não só representa o defeito congênito mais comum, mas também contribui com o maior percentual da mortalidade infantil ao nascimento. $O$ tratamento dessa cardiopatia é o mais caro nos hospitais pediátricos em comparação com todos os outros defeitos congênitos, devido a sua gravidade e complexidade do tratamento.

O tratamento dessa síndrome é invasivo, sendo que o diagnostico precoce, se possível, intra-uterino, permite a introdução rápida de medidas de suporte, visando a estabilização do neonato e preparo pré-operatório.

As últimas décadas apresentam significativas melhorias na sobrevida de crianças com SHCE, que se submeteram ao um 
procedimento de Norwood, pensado para ser associado com técnicas cirúrgicas modificadas, alterações na duração da parada circulatória e do tipo de perfusão e mudanças na gestão de cuidados intensivos pré e pós-operatório. Apesar da melhoria dos resultados, após uma fase de reparação, cuidado compassivo e interrupção precoce da gravidez permanecem escolhas populares em toda a Europa, Ásia e Polynesia ${ }^{16-18}$.

Sem tratamento, 95\% dos bebês com SHCE morrem no primeiro mês de vida. Para o tratamento é necessário realizar três cirurgias cardíacas durante os primeiros dois anos de vida ou um transplante cardíaco. Devido aos grandes avanços na cirurgia e na medicina, muitas crianças que nascem com SHCE agora estão tendo bons resultados. No entanto, esses tratamentos envolvem muitas experiências estressantes e riscos. Os tratamentos não são uma "cura" e as crianças precisarão de atendimento especializado pelo resto de suas vidas ${ }^{19}$. 
CAPÍTULO 2

ACESSO À TECNOLOGIA E AOS SERVIÇOS DE SAÚDE DE ALTA COMPLEXIDADE NA ÁREA MATERNO-INFANTIL 

O desafio atual para os profissionais de saúde é o emprego das tecnologias com bom senso e de forma criteriosa, com a finalidade de oferecer uma qualidade de vida aos indivíduos que assistem. Embora indiscutivelmente necessário, o uso da tecnologia deve considerar os potenciais riscos e benefícios.

Torna-se imprescindível a reflexão ética sobre a dimensão da nossa responsabilidade, enquanto agentes e produtores da técnica, mas também enquanto profissionais da saúde, que, mediante utilização de tecnologias em associação com atitudes, gestos, palavras, experiências e intuições, tomam para si a tarefa de cuidar. Portanto, é necessária uma avaliação crítica e reflexiva, sob o ponto de vista ético, dos custos, da qualidade da assistência, dos benefícios, das limitações, dos riscos e da adequação da tecnologia no cuidado neonatal ${ }^{20}$.

A tecnologia, como fundamento do cuidado materno-infantil, em especial, requer um repensar de todas as formas de relacionamento entre bebês, profissionais e família, na adequação de sua utilização a diversos saberes, oferecendo cuidado individualizado, seguro, ético e humano ${ }^{20}$.

A forma mais comum do emprego da tecnologia na área materno infantil é a ultrassonografia obstétrica, surgiu em fins dos anos 1950, como uma ferramenta diagnóstica, e adquiriu gradualmente um papel chave como produtora, de novos saberes, no decorrer da gestação, e de uma nova "cultura visual" em torno da gravidez. A partir de fins da década de 1980, a ultrassonografia obstétrica tornou-se uma prática considerada indispensável na detecção de anormalidades durante o processo gestacional ${ }^{21}$.

As tecnologias visuais e as de imagem, em particular, ocupam uma posição de destaque como produtora, ao mesmo tempo, de "lazer" e de "verdades". É uma tecnologia que detém um caráter interativo, na medida em que o profissional que realiza o exame, ao mesmo tempo focaliza as imagens, decodifica-as e busca outras incidências à medida que prossegue em sua realização ${ }^{21}$. 
Contudo a ultrassonografia obstétrica, ainda, tem sido subutilizada no rastreamento pré-natal de cardiopatias congênitas. O treinamento dirigido dos ultrassonografistas e a conscientização do meio obstétrico e da própria população podem ser os instrumentos para aumentar a eficácia desse método ${ }^{22}$.

Por outro lado, conforme descrito no capítulo 1, a ecocardiografia fetal, é uma ferramenta que encontra-se bem consolidada no diagnóstico de cardiopatias congênitas. Se o diagnóstico de uma malformação cardíaca for estabelecido, a conduta terapêutica dependerá do local de atendimento, do comprometimento funcional atual, potencial ou previsível e da maturidade fetal. A par do tratamento clínico medicamentoso, o transporte intrauterino do feto, o planejamento do atendimento perinatal ou a intervenção intrauterina poderão ser equacionados ${ }^{10}$.

Os avanços diagnósticos e terapêuticos da cardiologia fetal contemporânea caminham lado a lado com o desenvolvimento de inúmeras correntes de pensamento, que buscam questões técnicas, científicas, éticas, morais, legais, religiosas e emocionais. Em última análise, os profissionais de saúde, que se relacionam com um paciente protegido pelo útero materno, precisam questionar, incessantemente, se suas atitudes e habilidades estão ou não trazendo perspectivas de maior bem-estar ao feto e sua família. Se a resposta, naquele instante, for positiva, a busca das fronteiras da vida pode transpor os limites do impossível ${ }^{10}$.

Entretanto, estas perspectivas de tratamento citadas acima, só poderão ser atendidas se as gestantes de alto risco tiverem acesso aos serviços de alta complexidade.

O acesso está relacionado à capacidade de um grupo para buscar e obter atenção, sendo considerado como a possibilidade de utilizar serviços de saúde quando necessário. O acesso expressa as características da oferta, que facilitam ou obstruem a capacidade de as pessoas usarem serviços de saúde quando deles necessitarem ${ }^{23}$. 
Desse modo, torna-se necessário compreender como se dá o acesso aos serviços de alta complexidade, sabemos que o acesso universal, igualitário e ordenado às ações e serviços de saúde iniciase pelas portas de entrada do SUS e que se completa na rede regionalizada e hierarquizada ${ }^{23}$.

Evidencia-se que é grande o desafio de adequar a oferta de saúde ao perfil das necessidades e prioridades da população, garantindo serviços de média e alta complexidade a todos os municípios brasileiros, pois essas demandas geralmente ultrapassam a esfera municipal ou microrregional, principalmente nos Municípios de pequeno e médio porte ${ }^{24}$.

Os determinantes do acesso à saúde estão relacionados às características que, de um lado, referem-se à oferta dos serviços e do outro à demanda da população por cuidados de saúde, além de haver uma inter-relação entre eles. Sendo assim, as necessidades de saúde das pessoas, suas características sociodemográficas e culturais são entendidas como fatores determinantes para utilização dos serviços, bem como os aspectos a eles relacionados, tais como: características dos profissionais, experiência profissional e tipo de prática exercida ${ }^{25}$.

Conforme descrito no capítulo anterior, embora o acesso ao pré-natal seja praticamente universal, a qualidade desse atendimento, ainda, não é considerado satisfatório, sendo necessário que o Governo Federal, por meio do MS, assim como os Estados e Municípios, desenvolva estratégias que possibilitem a organização dos sistemas de atenção com o estabelecimento de compromisso e responsabilização pelo cuidado em todos os níveis da atenção à mulher no ciclo gravídico puerperal. Em muitos lugares a mulher, ainda, peregrina por vários serviços para encontrar uma vaga no momento do parto. e o modelo de atenção nos serviços não utiliza toda a tecnologia apropriada e recomendada para a assistência segura e humanizada ao parto e nascimento. Torna-se imperativo garantir a continuidade do cuidado assegurando o 
seguimento da mulher e da criança no pós-parto, assim como no acompanhamento do desenvolvimento da criança para que ela alcance todo seu potencial intelectual, cognitivo e motor, principalmente nos seus primeiros vinte e quatro meses de vida ${ }^{26}$.

Durante a gravidez e o parto, as mulheres vivenciam várias alterações físicas e emocionais e nesse processo, seus valores e crenças, defrontam-se com a estrutura social e cultural dos profissionais dos serviços de saúde. Ao procurar as instituições para atendimento das necessidades durante a gravidez e parto, trazem consigo expectativas e preocupações que têm relação com as experiências de vida delas, o período que antecede o parto é caracterizado por incertezas, pelo enfrentamento de situações desconhecidas, como o acesso à instituição, o desconhecimento da sua dinâmica e de como será prestada a assistência, provocando sentimentos de insegurança e estresse $\mathrm{e}^{27}$.

Ressaltamos, portanto, que o acesso aos serviços de saúde envolve aspectos que extrapolam a racionalidade de previsão da assistência à saúde, principalmente, se relacionados à resolutividade das ações desenvolvidas. Fica claro que a questão do acesso aos serviços de saúde enfatiza a importância da relação estabelecida entre profissionais de saúde e usuários, assim como as estratégias utilizadas por ambos para conseguir atender suas necessidades.

Apesar das propostas de uma rede de atenção à saúde e complementar entre o público e privado; atendimento a uma demanda organizada, sem negligenciar necessidades individuais, prestado por uma equipe interdisciplinar, centrado nos usuários com a coparticipação dessas na busca de soluções para os problemas coletivos; a inclusão e o acesso à atenção, às práticas de integralidade não têm sido desenvolvidas de forma satisfatória no setor saúde, o que coloca em evidência a questão do acesso em saúde ${ }^{28}$.

Nesse sentido, uma das estratégias do governo foi a implementação de uma Central Nacional de Regulação da Alta 
Complexidade (CNRAC), que foi desenvolvida pelo Ministério da Saúde em parceria com o Departamento de Regulação, Avaliação e Controle-DF (DERAC) e o Departamento de Informática do SUS (DATASUS), sendo instituída pela Portaria GM/MS n² 2309, de 19 de dezembro de 2001, a fim de contribuir para a melhoria contínua dos procedimentos relacionados ao financiamento das ações de saúde e controle de pagamentos aos prestadores de serviços que em determinado período, realizaram procedimentos ambulatoriais $\mathrm{e}$ hospitalares de alta complexidade para os estados e municípios. O sistema CNRAC é uma ferramenta de gerenciamento direcionada as DERAC-DF, secretarias estaduais e municipais de saúde, e seus respectivos estabelecimentos de saúde e tem como objetivos principais: regular o fluxo da referência interestadual de pacientes que necessitam de assistência hospitalar de alta complexidade; registrar as demandas dos estados com ausência ou insuficiência de oferta em alta complexidade hospitalar; mapear a migração dos usuários do SUS a partir de seu local de residência e do registro de seu atendimento em outro estado, por especialidade e por procedimento e disponibilizar informações para respaldar outras ações em saúde que impeçam as diferenças regionais e as dificuldades de acesso de populações menos privilegiadas. As especialidades contempladas pelo CNRAC são: Cardiologia; Oncologia; Neurologia/Neurocirurgia; Gastroenterologia e Traumatoortopedia $^{29}$.

$\mathrm{O}$ acesso aos serviços de alta complexidade em especial ao tratamento da SHCE é ainda mais complexo o que causa um descompasso entre o aumento das necessidades proporcionado pelos avanços tecnológicos, e a oferta dos serviços de saúde, tendo em vista que estes serviços estão localizados na região Sudeste, confirmando as desigualdades regionais em saúde em nosso País. 

CAPÍTULO 3

REFERENCIAIS TEÓRICO- METODOLÓGICOS

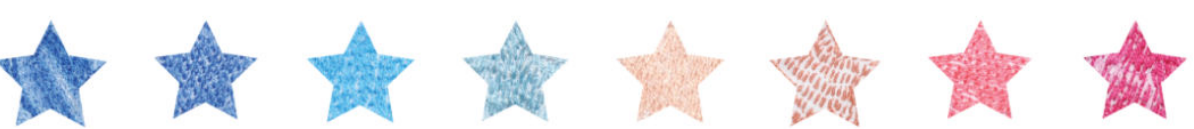





\subsection{Opção pela pesquisa qualitativa}

Optamos pela pesquisa qualitativa para este estudo, pois a mesma permite ao pesquisador apreender os modos como os participantes do estudo enfrentam o fenômeno focalizado, possibilitando a compreensão da dinâmica e a estrutura interna dos eventos, do ponto de vista de quem os vivencia.

A pesquisa qualitativa visa compreender a lógica interna de grupos, instituições e atores quanto aos valores culturais e representações sobre sua história e temas específicos; relações entre indivíduos, instituições e movimentos sociais; processos históricos, sociais e de implementação de políticas públicas e sociais $^{30}$.

A abordagem qualitativa responde a questões muito particulares, como o universo dos significados, dos motivos, das aspirações, das crenças, dos valores e das atitudes ${ }^{30}$.

Os pressupostos da pesquisa qualitativa são em primeiro lugar a parte do reconhecimento de que o mundo é real, embora se possa argumentar que exista independentemente de qualquer coisa ou pessoa, só existe de fato, na medida em que nós tomamos parte dele e ele faz sentido para nós. Em segundo lugar é que a sociedade é constituída de microprocessos que, em seu conjunto, configuram as estruturas maciças, ou seja, a realidade social não é um todo unitário, mas uma multiplicidade de processos sociais que atuam simultaneamente, em temporalidades diferenciadas, compondo, esses sim, uma totalidade ${ }^{31}$.

Crescem a consciência e o compromisso de que a pesquisa é uma prática válida e necessária na construção da vida social. Os pesquisadores que optam pela pesquisa qualitativa, ao decidir pela descoberta de novas vias investigativas, não pretendem furtar-se ao rigor e à objetividade, mas reconhecer que a experiência humana 
não pode ser confinada aos métodos nomotéticos de analisá-la e descrevê-la ${ }^{32}$.

Nessa perspectiva, o foco de atenção da pesquisa qualitativa está centrado na importância de se conhecer, entender e interpretar a natureza dos eventos, almejando sempre a compreensão e não a mera explicação do fenômeno estudado ${ }^{33}$.

A pesquisa qualitativa tem seu interesse voltado à experiência humana, com ênfase em seus processos e nos significados atribuídos pelas pessoas aos fenômenos vivenciados, permitindo a elucidação de seus modos de proceder frente a esses eventos ${ }^{33,34}$. Sua relevância baseia-se na possibilidade de compreensão de valores culturais e nas representações de um determinado grupo de temas específicos e, assim, ao buscar a compreensão e a explicação das relações humanas, ocupa-se do universo de significados, motivos, crenças, valores, atitudes e hábitos dos homens ${ }^{35}$.

A investigação qualitativa é, em si, um grande campo de investigação que interliga os campos da educação, trabalho social, comunicação, psicologia, saúde, história, estudos organizacionais, antropologia e sociologia, tecendo uma grande e complexa rede de conceitos, suposições e termos ${ }^{36}$.

$\mathrm{Na}$ área da saúde, um trabalho de pesquisa competente precisa dar conta da complexidade da área que envolve o corpo, a saúde e a doença, contemplando suas diversas dimensões epidemiológicas, religiosa social e cultural. Buscando compreender essa diversidade é que as Ciências Sociais, em especial, a Antropologia, tomam como objeto de estudo o corpo, a saúde e a doença ${ }^{31}$.

Ao estudar as diferentes vertentes teórico- metodológicas compreendi que a Antropologia e o Método Etnográfico, possibilitariam que eu percebesse e entendesse as experiências, e as vivências das participantes, e como em suas diferentes culturas lidaram com a realidade na trajetória da doença dos seus filhos 
cardiopatas. Essa forma de pesquisa exige que o pesquisador vivencie e conviva com os participantes do estudo e assim construa dessa experiência com o conhecimento acerca da validade em si mesmo, e não simplesmente "senso comum" e, portanto, fazendo necessário "estar lá" e "escrever aqui" como sugere a Etnografia ${ }^{37}$.

\subsection{Antropologia cultural}

A Antropologia vem sendo utilizada por profissionais de diferentes áreas envolvidos em estudos que se preocupam em problematizar e compreender como os indivíduos vivem seu mundo. Problematizar a ideia de experiência significa assumir que o modo como os indivíduos compreendem e se engajam ativamente nas situações em que se encontram, ao longo de suas vidas, não pode ser simplesmente, deduzido de um sistema coerente e ordenado de ideias, símbolos ou representações ${ }^{38}$.

O estudo da Antropologia da Saúde tem apresentado um alto índice de crescimento, não apenas tem despertado interesse por parte dos diversos tipos de profissionais da saúde como também tem sido reconhecido em diferentes instituições de ensino e pesquisa. Esse fato pode ser evidenciado pela vasta produção de livros e revistas publicados principalmente nos Estado Unidos, Inglaterra, Canadá e França ${ }^{39}$.

A Antropologia pode ser definida como a ciência que estuda o outro, esse outro definido das mais diversas formas ao longo da história da própria disciplina. A história da Antropologia pode ser vista, como "o modo pelo qual os homens perceberam suas diferenças ao longo de um dado período de tempo"31.

Cabe destacar, que a Antropologia não se reproduz como uma ciência normal de paradigmas estabelecidos, mas por uma determinada maneira de vincular teoria e pesquisa, de modo a favorecer novas descobertas. 
Um instrumento fundamental da Antropologia para estudar o outro é o conceito de cultura, que expressa a forma como a diferença é pensada e como é concebido o outro. Atualmente é consenso entre os antropólogos que a cultura deve ser entendida como um conjunto de regras que orienta e dá significado às práticas e à visão de mundo de um determinado grupo social ${ }^{40}$.

A cultura é tomada, assim, por seu caráter simbólico. Ela é a forma que determinado grupo social estabelece para classificar as coisas e atribuir-Ihes um significado. E, nessa concepção, a cultura é sempre arbitrária, pois cada grupo pode atribuir um significado diferente a um mesmo objeto ou fenômeno. É uma espécie de código que um determinado grupo compartilha, as diferentes dimensões da cultura se encontram logicamente entrelaçadas e compõem este código que é a própria cultura ${ }^{40}$.

"Culturas são sistemas, de padrões de comportamento socialmente transmitidos, que servem para adaptar as comunidades humanas aos seus embasamentos biológicos". Esse modo de vida das comunidades inclui tecnologias e modos de organização econômica, padrões de estabelecimento, de agrupamento social e organização política, crenças e práticas religiosas, e assim por diante $^{41}$.

Todos os homens são geneticamente aptos para receber um programa, e este programa é que chamamos de cultura. E esta formulação que consideramos uma nova maneira de encarar a unidade da espécie. "Um dos mais significativos fatos sobre nós pode ser finalmente a constatação de que todos nascemos com um equipamento para viver mil vidas, mas terminamos no fim vivendo uma só". Em outras palavras, a criança está apta ao nascer a ser socializada em qualquer cultura existente. Esta amplitude de possibilidades, entretanto, será limitada pelo contexto real e especifico onde de fato crescer $^{40}$. Destacam-se dois enfoques teóricos na conceituação de cultura: o primeiro comportamental, que se refere à observação do comportamento dos indivíduos em um 
determinado grupo social e o segundo, cognitivo, busca conhecer e compreender as crenças, os valores e os conhecimentos desses indivíduos na abordagem do tema escolhido ${ }^{42}$.

A cultura é um dos principais conceitos da Antropologia e tem um compromisso com o paradigma interpretativo, caracterizado pelo processo indutivo e pela metodologia qualitativa.

A Antropologia torna possível uma perspectiva crítica frente às nossas verdades mais fundamentais e favorece a construção de um novo paradigma para a abordagem do processo saúde-doença ${ }^{43}$.

A Antropologia busca entender, o significado específico que o corpo, saúde e doença assumem numa dada sociedade, visto que os registros de normalidade e anormalidade são, antes de tudo, determinados a partir de valores. A busca desse relativismo e da singularidade dos grupos sociais pressupõe que o real só pode ser apreendido a partir da ordem simbólica, ou seja, é o simbólico que por meio dos sistemas de classificação e de sentido define o real. A realidade é entendida assim como uma construção social na qual o fato concreto - a doença, por exemplo, só existe a partir da ordem simbólica ${ }^{31}$.

As propostas de compreensão da realidade, por parte da Antropologia, têm de estar integradas num projeto maior de transformação, penetrando em questões relativas à subjetividade, corporalidade e ação, aspectos fundamentais para o entendimento dos modos socialmente compartilhados por meio dos quais os indivíduos identificam, explicam e reagem à doença. Seu papel não é neutro e nem solitário; seja como ciência básica, seja no campo da contribuição com outras práticas sociais, ela está submetida às contingências do tempo histórico e insere-se nas correntes de pensamento de sua época ${ }^{35}$.

A Antropologia tem sido utilizada como uma perspectiva complementar e enriquecedora, na abordagem de temas relativos ao processo saúde e doença e aos universos sociais e culturais onde ocorrem ${ }^{44}$. 
A valorização dos fenômenos cognitivos, semiológicos e simbólicos é da maior relevância na Antropologia interpretativa, como paradigma surgido, nas últimas décadas, e difundido cada vez mais nos estudos realizados pelas ciências sociais.

Este estudo foi pensado como um processo de conjunção de fatos e experiências das participantes, que se aliam à construção da realidade. Para tanto, a opção pelo objeto do estudo direcionou-nos à corrente interpretativa da Antropologia, que tem Clifford Geertz como um dos mais originais e ativos pensadores sociais.

O objetivo da Antropologia é o alargamento do universo do discurso humano. Portanto, não é uma ciência experimental em busca de leis, mas uma ciência interpretativa, à procura de significados. A cultura modela os indivíduos como espécie única, mas também como indivíduos em separado, tornando-se individual. A cultura é definida como sendo o padrão dos significados, transmitido historicamente e incorporado em símbolos, é um sistema de concepções herdadas, expresso de forma simbólica por meio do qual os homens se comunicam, perpetuam e desenvolvem seu conhecimento e atitudes em relação à vida ${ }^{40}$.

Como sistemas entrelaçados de signos interpretáveis, a cultura não é um poder, algo ao qual podem ser atribuídos casualmente os acontecimentos sociais, os comportamentos, as instituições ou os processos; ela é um contexto, algo dentro do qual eles podem ser descritos de forma inteligível e com densidade. Os antropólogos não estudam as aldeias, eles estudam nas aldeias, baseando sua assertiva no fato de que diferentes temas podem ser pesquisados em diferentes lugares e isso não faz do local o que se está pesquisando ${ }^{40}$.

A vocação essencial da Antropologia interpretativa não é responder às indagações mais profundas dos pesquisadores e sim colocar à sua disposição as respostas dadas pelos indivíduos, de uma determinada cultura, com a finalidade de incluí-las no registro do corpo de conhecimento da teoria. Assim, o comportamento do 
homem é dirigido por padrões culturais que, caso inexistissem, a vivência humana não teria significado ou forma, uma vez que a totalidade acumulada de tais padrões, que constitui a cultura, é a principal base de sua especificidade ${ }^{40}$

$\mathrm{O}$ ato de pensar o indivíduo, incluindo a interpretação, tem características privada e pública, os símbolos públicos são observáveis e podem ser verificados, os sentimentos e as motivações são expressos pelas atitudes manifestadas publicamente, fato não observado nos símbolos privados, pois são manifestados por estados não observáveis. O comportamento dos indivíduos varia de acordo com o grau de importância que a experiência vivida acarretou para os mesmos. Assim, a motivação para agir dependerá das escalas de valor que diferenciam a reação de cada um frente a um dado evento ${ }^{45}$.

Nessa ótica, o universo de símbolos e significados permite aos indivíduos de um grupo, interpretar sua experiência e conduzir suas ações, enfatizando a importância da cultura na construção do fenômeno a ser estudado.

Sendo assim, neste estudo, foi possível constatar as percepções, os sentimentos, as interpretações que as participantes experimentaram na trajetória do parto e puerpério com seus bebês cardiopatas, bem como na avaliação do atendimento, do serviço e dos profissionais com os quais interagiram.

Fundamentada nessas premissas é que me propus a compreender, por meio do método etnográfico, a percepção de mulheres, cujos bebês cardiopatas nasceram no serviço em que atuo. 


\subsection{Método Etnográfico}

Longamente consagrada como um método, uma orientação teórica na Antropologia, a Etnografia vem sendo adotada como uma metodologia útil em estudos culturais, estudos de gênero, no campo da saúde, do planejamento, entre outros.

A Etnografia é a arte e a ciência de descrever um grupo humano - suas instituições, seus comportamentos interpessoais, suas produções materiais e suas crenças. Os etnógrafos ocupam-se basicamente, das vidas cotidianas das pessoas que estudam, coletando dados sobre as experiências humanas vividas, a fim de discernir padrões previsíveis e de descrever todas as instâncias imagináveis de interação ou produção ${ }^{40}$.

A Etnografia é feita in loco e o etnógrafo é, na medida do possível, alguém que participa subjetivamente nas vidas daqueles que estão sendo estudados, assim como um observador objetivo daquelas vidas.

O etnógrafo "inscreve-se" no discurso social: ele o anota. Ao fazê-lo, ele o transforma de acontecimento passado, que existe apenas em seu próprio momento de ocorrência, em um relato, que existe em sua inscrição e que pode ser consultado novamente. Portanto, o etnógrafo, observa, registra e analisa ${ }^{40}$.

Nas ciências sociais o pesquisador lida com seres humanos que, por razões culturais de classe, de faixa etária, ou por qualquer outro motivo, tem um substrato comum de identidade com o investigador, tornando-os solidariamente imbricados e comprometidos. "Numa ciência, onde o observador é da mesma natureza que o objeto, e o observador é, ele próprio, uma parte de sua observação ${ }^{30}$.

A Etnografia como método é diferente de outros modos de fazer pesquisa em ciência social. Esse método é baseado na pesquisa de campo, sendo conduzido no local onde as pessoas 
vivem e não em laboratórios onde o pesquisador controla os elementos do comportamento a ser medido ou observado. É personalizado, por ser desenvolvido por pesquisadores que, no dia a dia, estão face a face com as pessoas que estão estudando e que, assim, são tanto participantes como observadores das vidas em estudo; é multifatorial, pelo uso de duas ou mais técnicas de coleta de dados, para triangular uma conclusão, que pode ser considerada fortalecida pelas múltiplas vias com que foi alcançada para uma discussão desse tema, requer um compromisso de longo prazo, é investigado por pesquisadores que pretendem interagir com as pessoas que eles estão estudando durante um longo período de tempo, embora o tempo exato possa variar, de algumas semanas a um ano ou mais; é indutivo de modo a usar um acúmulo descritivo de detalhe para construir modelos gerais ou teorias explicativas, e não para testar hipóteses derivadas de teorias ou modelos existentes; é dialógico, realizado por pesquisadores cujas conclusões e interpretações podem ser discutidas pelos participantes na medida em que elas vão se formando; é holístico por revelar o retrato mais completo possível do grupo em estudo ${ }^{31}$.

Ao contrário da abordagem etnocêntrica, a abordagem etnográfica se constrói tomando como base a ideia de que o comportamento humano só pode ser devidamente compreendido e explicado se tomarmos como referência o contexto social ${ }^{31}$.

Logo, no método etnográfico, há a presença intensa do pesquisador no contexto pesquisado, além da observação participante, de entrevistas informais e semiestruturadas e de documentos escritos, resultando na apresentação de um texto interpretativo (fruto da análise dos dados recolhidos em campo acerca do fenômeno sociocultural que constitui o objeto do estudo).

O saber teórico vai sendo construído junto com a coleta de dados, em um processo conduzido com sensibilidade reflexiva, tomando em conta a própria experiência, no campo, junto às pessoas com as quais o pesquisador trabalha ${ }^{45}$. 
A Etnografia favorece a interpretação de fatos sociais, fortemente, entrelaçados e apoiados no papel da cultura, entendida na construção coletiva e individual. Tem, como uma das principais características, a busca pelo significado do evento, a partir do ponto de vista dos sujeitos. Ao utilizar a Etnografia como método de pesquisa, o pesquisador passa a procurar as respostas fornecidas pelos sujeitos da pesquisa, colocando-os à disposição do estudo que passa a participar efetivamente do evento como parte de sua cultura pessoal, em um trabalho de imersão. Esses comportamentos são explicados conforme o contexto social em que ocorrem ${ }^{42}$.

A Etnografia cria condições para que sejam contempladas as particularidades dos fatos em momentos únicos, por sua base estar centrada na cultura, demarca as diferenças e propicia contestações e questionamentos ${ }^{40}$. O trabalho etnográfico pressupõe a capacidade de o pesquisador realizar uma "descrição densa", no sentido de que os dados não são apenas apreendidos, mas devem ser interpretados para que seus vários significados possam ser revelados.

O que diferencia esse processo de construir o conhecimento antropológico de outras obras científicas é que, nesse caso, revelam-se experiências concretas. Portanto, a experiência humana é um pressuposto para que se produza conhecimento antropológico e encontra-se presente em todas as etapas da produção desse conhecimento $^{46}$.

As principais técnicas de coleta de dados preconizadas pelo método etnográfico são: observação participante, a entrevista e a análise documental.

A observação participante é considerada parte essencial do trabalho de campo na pesquisa qualitativa, sendo considerada como um método que permite a compreensão da realidade. É definida como um processo no qual o pesquisador se coloca como observador de uma situação social, com a finalidade de realizar uma investigação científica. O observador, no caso, fica em relação direta 
com seus interlocutores no espaço social da pesquisa, na medida do possível, participando da vida social deles, no seu cenário cultural, mas com a finalidade de coletar dados e compreender o contexto da pesquisa. Por isso, o observador faz parte do contexto sob sua observação e, sem dúvida, modifica esse contexto, pois interfere nele, assim como é modificado pessoalmente ${ }^{30}$.

O pressuposto que fundamenta a observação participante é a necessidade que todo o pesquisador social tem de relativizar o espaço social de onde provém, aprendendo a se colocar no lugar do outro. A proximidade com os interlocutores, longe de ser inconveniente, é uma virtude e uma necessidade ${ }^{30}$.

A observação participante é a forma consciente de o pesquisador participar e compartilhar das atividades do grupo ou instituição a ser estudada, de modo que ao interagir com esse grupo cultural ele possa interpretar o significado dos eventos vivenciados por ele ${ }^{30}$.

A observação participante permite examinar com todos os sentidos um evento, um grupo de pessoas, um indivíduo dentro de um contexto, com objetivo de descrevê-lo; não é uma observação comum $^{31}$.

$\mathrm{Na}$ pesquisa qualitativa realiza-se a observação participante, por que há muitos elementos que não podem ser apreendidos pela fala ou pela escrita: o ambiente, os comportamentos individuais e grupais, a linguagem não verbal, a sequência e a temporalidade dos eventos. A observação participante é uma técnica para a coleta de dados que complementa as entrevistas realizadas.

Outra técnica bastante empregada pela Etnografia é a entrevista, a qual é tomada no sentido amplo de comunicação verbal, e no sentido restrito de coleta de informações sobre determinado tema científico, é a estratégia mais usada no processo de trabalho de campo ${ }^{30,47}$. É um ato de colaboração e apenas justifica-se como tal em processos democráticos. 
A entrevista é considerada um processo de interação social entre duas pessoas no qual uma delas, o entrevistador, tem por objetivo a obtenção de informações por parte do outro, o entrevistado ${ }^{48}$.

A entrevista possui três degraus: a pré-entrevista, a entrevista e a pós-entrevista ${ }^{49}$.

A pré-entrevista corresponde à etapa de preparação do encontro que se dará a gravação. Há a necessidade que haja um entendimento preparatório para que as pessoas a serem entrevistadas tenham conhecimento do projeto e do âmbito de sua participação. A entrevista deve ser realizada segundo a conveniência do entrevistado e podem ser: únicas ou múltiplas, estimuladas ou não (com a presença de fotos e documentos), diretivas ou não (com perguntas ou questionários) e longas ou breves. A pós-entrevista é a etapa que segue a realização da entrevista, onde contatos devem ser mantidos, a fim de estabelecer a continuidade do processo.

Finalizadas as gravações das entrevistas, os pesquisadores partem para a etapa de transcrição, a qual é a passagem da gravação oral para o escrito e que envolve a textualização e a transcriação. Na fase de textualização são suprimidas as perguntas que, fundidas nas resposta, superam sua importância. A textualização realizada a partir da definição de palavras-chave que servem para mostrar a incidência das ênfases dadas em algumas situações e a transcriação compromete-se a ser um texto recriado em sua plenitude, correspondendo à finalização do mesmo.

No ato da gravação da entrevista, deve ficar registrado que a mesma terá uma conferência e que nada será publicado sem autorização prévia do participante do estudo.O principio da flexibilização do que entra e sai da entrevista é fundamental, devendo haver entre as partes um entendimento que permita diálogo sobre a importância ou não dos cortes ${ }^{49}$.

A entrevista etnográfica inclui os projetos na qual os pesquisadores têm que estabelecer um relacionamento próximo e de 
respeito com os entrevistados para que flua uma troca de visões. Tanto a frequência, como o tempo e a qualidade do relacionamento é que distingue uma entrevista etnográfica das demais ${ }^{50}$.

Com esses referenciais aprendidos, apresento no próximo capítulo o caminho metodológico percorrido para o alcance do objetivo deste estudo. 

CAPÍTULO 4

CAMINHO METODOLÓGICO

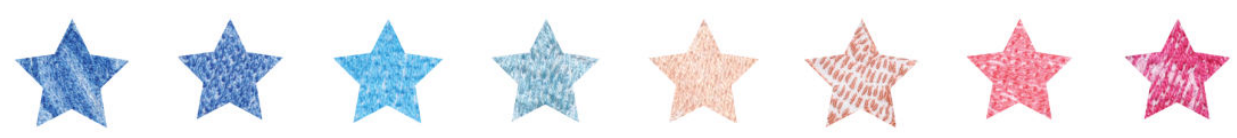





\subsection{Contexto da investigação}

Esta pesquisa teve como locus a Associação do Sanatório Sírio Hospital do Coração - Hcor / São Paulo.

A Associação do Sanatório Sírio foi a semente do HCor. Semente que só germinou porque as senhoras voluntárias da Associação entenderam a importância de estender a todos os doentes, economicamente vulneráveis uma assistência à saúde de excelência, em especial às crianças cardiopatas.

As atividades da referida instituição iniciaram-se em 1976, tendo como objetivos: promover a recuperação da saúde com excelência e ética, atuar com pioneirismo em cardiologia, compartilhar recursos tecnológicos e conhecimentos com outras especialidades e associar ensino e pesquisa, valorizando a participação multiprofissional e multidisciplinar na assistência humanizada, visando à prevenção e ao bem-estar com qualidade de vida.

Após décadas atendendo somente crianças com diagnóstico de cardiopatias congênitas, o HCor ampliou a sua atuação na filantropia, para além da assistência, apoiando projetos e estratégias do MS, fazendo parte do PROADI-SUS.

Conforme dito anteriormente, o HCor é uma instituição filantrópica, sem fins lucrativos, reconhecida como um dos principais centros de tratamento de doenças cardiovasculares da América Latina, acreditado pela $\mathrm{JCl}$, desde 2006, e reconhecido como Hospital de Excelência pelo MS, contribuindo para a melhoria da saúde pública, por meio de ações sociais.

Em todas as unidades do HCor os pacientes admitidos são atendidos por uma equipe multiprofissional composta por médicos, enfermeiros, fisioterapeutas, farmacêuticos, nutricionistas, psicólogos, fonoaudiólogos e assistentes sociais. Além disso, o 
hospital possui todos os serviços de apoio para alta complexidade, como laboratório clínico, serviço de imagem (tomografia, $\mathrm{RX}$, ressonância magnética, ecocardiografia, dentre outros), banco de sangue, bem como uma estrutura para pesquisa diagnóstica laboratorial e radiológica.

O HCor tem na cardiologia sua especialidade precursora e um dos principais pilares de sua reconhecida condição de excelência. $O$ mesmo compromisso da cardiologia para adultos norteia o trabalho da equipe, que se dedica às cardiopatias congênitas e à cardiologia pediátrica, uma área do HCor considerada referência nacional no atendimento às crianças e adolescentes e que, desde o final de 2008, compreende também a cardiologia fetal.

Há mais de trinta anos, o HCor disponibiliza toda a sua experiência à disposição de crianças com diagnósitco de cardiopatias complexas. Esse trabalho é oferecido tanto a pacientes particulares ou portadores de planos de saúde como a pacientes em vulnerabilidade social que façam parte do programa de filantropia do hospital. Uma equipe multidisciplinar, formada por cardiopediatras, cirurgiões cardíacos pediátricos, intervencionistas, enfermeiros, psicólogos, fisioterapeutas, nutricionistas e assistentes sociais atua em conjunto no atendimento humanizado e especializado nessa área.

Além da Cardiologia Clínica e Cirúrgica, destaca-se em Ortopedia, Oncologia, Neurocirurgia, Urologia, entre outras especialidades. Dispõe, ainda, do Instituto de Ensino e Pesquisa ${ }^{51}$.

A estrutura organizacional do hospital é assim constituída: Diretora Presidente, Diretor Geral, Diretor Clínico, Superintendente Corporativo CEO, Superintendente Médico, Superintendente de Qualidade e Responsabilidade Social, Superintendente Serviços Ambulatoriais, Superintendente Comercial, Superintendente de Operações e Superintendente Financeiro.

Atualmente, o HCor dispõe de 311 leitos, distribuídos nas Unidades de Internação, Unidade de Terapia Intensiva Adulto, 
Unidade de Terapia Intensiva Pediátrica e Neonatal, Unidade Coronária, Pediatria Filantrópica.

Para o atendimento da demanda assistencial o HCor conta com 2.272 colaboradores em regime de CLT (Consolidação das Leis do Trabalho) e 508 em regime de terceirização e com um corpo clínico aberto com, aproximadamente, 1110 médicos credenciados.

A Unidade de Cardiologia Fetal, cenário deste estudo, foi inaugurada em 2009 e tem como objetivos principais: diagnóstico pré-natal de malformações cardíacas, diagnóstico pré-natal de malformações associadas e cromossomopatias, terapêutica prénatal quando necessária (medicamentosa e intervencionista) e atendimento ao parto de fetos que necessitam atendimento neonatal imediato em Cardiologia. É constituída por seis leitos na Unidade de Terapia Intensiva Neonatal e oito na Pediátrica. Para tanto, conta com uma equipe multidisciplinar, constituída por: ecocardiografistas fetais, obstetras, especialistas em cirurgia e medicina fetal, neonatologistas, enfermeiras obstétricas, assistentes sociais, psicólogas, nutricionistas, fisioterapeutas.

A organização e as competências, bem como as atribuições dos recursos humanos dessa Unidade constam no Regimento Interno do Serviço (ANEXO 1).

A entrevista, a seguir, com a Coordenadora da Unidade de Cardiologia Fetal do HCor, Dra Simone Pedra, ocorrida em 11 de novembro de 2013, revela como ocorreu o início das atividades dessa unidade e como vem sendo consolidado os seus processos de trabalho. 
"Em 1996 participei do atendimento prestado ao nascimento de um bebê com cardiopatia congênita, no Instituto Dante Pazanezze de Cardiologia. Na ocasião, era uma recém-cardiologista pediátrica e acredito que esse atendimento tenha despertado meu interesse por essa especialidade.

Assim, há cerca de dez anos começamos a amadurecer a ideia de atender os recém-nascidos aqui no HCor. Lembro-me que tudo se concretizou em uma reunião que tivemos na cardiologia pediátrica com o Dr. Adib Jatene, na qual discutimos as inovações na área de cardiologia pediátrica e dentre elas a intervenção cardíaca fetal. Nessa reunião, o Dr Adib me perguntou se eu considerava ser o momento de implementarmos um serviço para que os nenês cardiopatas nascessem no HCor. Disse-Ihe que sim e que as muitas maternidades estavam se estruturando para o atendimento de cardiologia pediátrica. A partir daí virou uma realidade...

Nessa direção, era necessário que a equipe do HCor se capacitasse ainda mais para esse tipo de atendimento. Assim, uma equipe de médicos e enfermeiros foram para Columbus, Ohio, que é um dos maiores centros de referência de tratamento SHCE, para participar dos simpósios referentes aos de procedimentos híbridos. Fomos nos inteirando da técnica, e de todos os detalhes necessários para que esses pacientes pudessem ser abordados de uma maneira segura e com resultados positivos.

Desse modo, em janeiro de 2009, estávamos com a equipe capacitada e serviço estruturado e acredito que o bebê número 1 , filantrópico, nasceu em fevereiro de 2009. Fomos gradativamente nos estruturando e crescendo para desenvolver a Unidade Fetal e hoje já contamos com mais de cento e cinquenta partos realizados aqui, sendo que, aproximadamente, dois terços desses são filantrópicos.

O maior desafio foi passar a atender a gestante, que é uma paciente nova na instituição, com características muito próprias e a 
equipe estava muito habituada a ter só cardiologia no hospital. Mas acredito que o medo foi diminuindo e a certeza, a segurança e a convicção de que estávamos no caminho certo foi aumentando e hoje lidamos com naturalidade com essa questão.

Hoje temos vinte casos de tratamento cardíaco, realizados no HCor, todos intra-útero. Isso corresponde a uma das maiores experiências, talvez segunda ou terceira experiência, do mundo, em termos numéricos. E recentemente, agora, nesse mês de outubro de 2013, saiu a nossa primeira publicação com os dados das intervenções fetais das nossas primeiras vinte; estamos com vinte seis, das quais umas quatro ou cinco não foram realizadas aqui, as demais foram todas aqui, e estamos com vários bebês que já sofreram a intervenção, nasceram aqui e estão bem, graças a Deus, um resultado bastante maduro.

Com relação ao acesso ao nosso serviço, eu acho que o processo de regulação do sistema de saúde é essencial, mas ele não é fácil de acontecer. Ele requer todo um planejamento, requer toda uma maturidade do sistema para melhorar. Tentamos um processo de regulação local, em termos de Município, mas ainda eu digo que a minoria dos bebês nascidos aqui foram realmente encaminhados pela central de regulação do Programa Mãe Paulistana. A grande maioria é uma procura individual, própria, da família, da rede de amigos, representantes e a rede conexão de conhecimentos mesmo, residentes, colegas, colegas de outros Estados, também uma participação forte da ONG Pequenos Corações, que hoje é muito acessada pelas gestantes que recebem diagnóstico de cardiopatia fetal. Então, embora desejássemos estar no processo totalmente regulado, recebendo pelo Centro Nacional de Regulação da Alta Complexidade (CNRAC), as gestantes que vêm de outros Estados, nós ainda não conseguimos; é um país enorme, é um sistema de saúde complexo com uma série de outros problemas a resolver... De qualquer maneira, nós não podemos deixar de atender essa livre demanda, porque nós temos o recurso, 
nós queremos atender esses pacientes, cada paciente que vem com sua história para cá nos ensina muito, em todos os sentidos, na parte técnica, na parte pessoal e espiritual. Acho que a gente convive com um pouquinho de cada um e nós estamos tentando sempre nos adequar à rede, nos adequar ao fluxo, mas o fluxo requer uma integração muito grande dentro do SUS.

Eu diria que a alta complexidade é muito concentrada no Município de São Paulo, depois nós temos alguns serviços em Minas Gerais, que é basicamente o Biocor; o Instituto de Cardiologia do Rio Grande do Sul e o Rio de Janeiro, que faz alguma coisa de HVE, principalmente nos últimos tempos. Eu diria que existe uma carência muito grande no norte e nordeste, em relação a serviços para atender cardiopatias de alta complexidade.

Uma questão muito importante no nosso projeto de filantropia da Unidade Fetal foi contribuir com a capacitação de outros centros, cujo objetivo principal é o desmitificar o coração fetal; temos capacitado os profissionais que fazem o ultrassom morfológico a observar o coração com uma técnica bastante simples. Em nosso país, nós temos uma taxa de diagnóstico pré-natal de cardiopatias congênitas, extremamente, baixa. Esse diagnóstico tem um papel importante, porque nós sabemos que metade das mortes neonatais ocorre por más formações cardíacas. Uma vez eliminadas questões básicas que interferiam na mortalidade infantil, que eram muito mais socioeconômicas e ambientais, a cardiopatia passa a ser um problema importante de saúde pública.

Nossos partos são $100 \%$ cesariana, eu enxergo da seguinte maneira, eu acho que é uma questão absolutamente cultural e eu diria que só há indicação, do ponto de vista médico, de cesárea, em aproximadamente $10 \%$ dos casos das cardiopatias neonatais. Os demais poderiam passar por um parto normal sem nenhum problema. Agora nosso problema é absolutamente de estrutura, eu precisaria ter obstetras de plantão que pudessem passar doze, vinte 
quatro horas acompanhando o trabalho de parto. Isso é inviável economicamente, nós não temos recurso físico e humano para isso.

Agora nós, ainda, temos muito que caminhar, pois nossos pacientes são de alto custo, requerem cuidados extremos, grande expertise e um número grande de pessoal para o manejo desse paciente, principalmente, da enfermagem. Eu acho que esse é um diferencial chave. Qualquer coisa diferente pode realmente afetar a criança. Agora o próprio manejo médico, de toda a equipe multidisciplinar, tem de ser muito acertado. O neonato cardiopata não permite erros, essa é a questão desse paciente, ele é perverso nesse sentido, porque ele não admite erros, os erros repercutem de uma maneira tão forte na criança... Isso requer então um alinhamento muito grande de toda equipe. No ponto de vista de manejo, para bons resultados em cardiologia pediátrica precisamos de três estruturas chaves que fazem a diferença: Centro Cirúrgico, Unidade de terapia Intensiva e Sala Hemodinâmica bastante alinhados.

Eu vejo a equipe muito motivada, isso é muito bom, acho que há uma participação muito positiva da equipe de enfermagem, a equipe de psicologia, nutrição, toda a equipe multidisciplinar. Eu acho que tem tudo para continuar crescendo. Você vê o quanto é importante, hoje, a participação de todos; até a participação do comercial é realmente importante, sei que alguns pacientes que nós conseguimos atender foi graças ao esforço desse pessoal. E para nós, cada um dos pacientes é muito valioso. Em todos os sentidos." 


\subsection{Aspectos éticos}

Este estudo foi submetido e aprovado por dois Comitês de Ética em Pesquisa, a saber: Comitê de Ética da Escola de Enfermagem da USP (ANEXO 2) e Comitê de Ética do HCor (ANEXO 3), sendo cadastrado na Plataforma Brasil sob o Protocolo 01023812.5.0000.5392.

O Termo de Consentimento Livre e Esclarecido (TCLE) foi elaborado conforme a legislação vigente na época, mantendo a confidencialidade e os devidos esclarecimentos sobre o estudo ${ }^{52}$ (APÊNDICE A).

Após a explicação completa e pormenorizada sobre a natureza do estudo, as participantes que concordaram em participar da pesquisa receberam, leram e assinaram duas vias do TCLE, ficando uma das vias com o pesquisador e outra em posse das participantes, com os respectivos contatos para dirimir qualquer dúvida existente por ambos.

\subsection{Participantes}

As participantes deste estudo foram constituídas por oito gestantes, cujos bebês tinham diagnóstico de cardiopatia congênita e que, portanto, acessaram a Unidade de Cardiologia Fetal do HCor, para o tratamento. Tal participação foi realizada em caráter voluntário.

Todas as gestantes foram atendidas pelo projeto da filantropia, viabilizada pelo PROADI/SUS-HCor, eram provenientes de diferentes Estados da Federação e maiores de 18 anos.

As participantes foram identificadas com a letra E (E1 a E8), codinome alusivo a "Estrela". 


\subsection{Coleta dos dados: a observação participante e a entrevista}

A coleta dos dados iniciou-se após o aval dos Comitês de Ética, sendo realizada por meio da observação participante e da entrevista semi- estruturada, no período de agosto de 2012 a agosto de 2013. Entretanto, a minha inserção no grupo da Unidade de Cardiologia Fetal do HCor iniciou-se no ano de 2010.

\subsubsection{Observação participante}

Na pesquisa qualitativa, a interação entre o pesquisador e os sujeitos pesquisados é essencial ${ }^{30}$.

Assim, a observação participante, juntamente, com a técnica de entrevista, despontaram como instrumentos essenciais na coleta de dados deste estudo. Tanto a observação participante como as entrevistas, bem como outras estratégias de coleta de dados, tais como o diário de campo e recurso fotográfico possibilitaram a fidedigna coleta dos dados.

A metodologia da pesquisa qualitativa requer perceber os participantes em suas falas, compreendê-las em seus comportamentos e ações e desvendá-las em suas experiências e vivências significativas.

Desse modo, fui ao encontro de gestantes que estivessem vivenciando o fenômeno que havia me proposto investigar. Para tanto, algumas barreiras precisavam ser vencidas, a saber: meu desconhecimento sobre as cardiopatias congênitas, como abordar a doença e como enfrentar a dor dessas gestantes de bebês cardiopatas.

No trabalho de campo, durante o mestrado, quando convivi com mães e bebês saudáveis, as dificuldades eram tratadas com 
tranquilidade, sempre mostrei-me de forma positiva e comunicativa, e por vezes a religião foi consolo e uma esperança de cura.

Neste trabalho o auto-enfrentamento foi inevitável, a religião por si só, não dava mais conta de "terceirizar" o que viria pela frente na vida dessas mulheres e de seus bebês, com uma das cardiopatias mais graves, a SHCE. Fazia-se necessário enfrentar o campo, compreender a lógica dessas mulheres e, de acordo com a pesquisa qualitativa compreender, naquele momento significava ter a capacidade de me colocar no lugar do outro, respeitar suas crenças e valores e entender que para a operacionalização deste estudo precisava estar ao lado das gestantes e da equipe que as assistia.

Nessa direção, lembrei-me de três princípios inegociáveis que aprendi com a Professora Maria Cecilia Minayo e que seriam fundamentais para o alcance desse propósito: o princípio da intersubjetividade (somos feitos da mesma matéria e espírito das pessoas que atendemos); o princípio da compreensão; o princípio do respeito à racionalidade de qualquer ser humano.

E foi assim, durante as discussões com minha orientadora, com os pares nas reuniões do grupo de pesquisa, com a equipe multidisciplidinar do HCor e no próprio Exame de Qualificação, que avaliou este projeto de pesquisa, que as questões referentes à participação/convite das gestantes para este estudo foram delineando-se. Lembro-me do dia do Exame de Qualificação, quando a Professora Dulce Gualda disse-me a seguinte frase: "Você vai sofrer muito com este trabalho"... Naquele momento, pensei, imagina, vou encontrar as participantes e encarar os problemas com meu jeito otimista de ser. Mas o primeiro contato com o campo mostrou-me que a experiente professora tinha razão e que a coleta dos dados seria intensa e, por vezes, sofrida.

A equipe da Unidade Fetal acolheu-me muito bem, a coordenadora do serviço foi receptiva à realização deste trabalho, proporcionando-me a interação com a equipe, a participação nas 
reuniões e o conhecimento dos desafios enfrentados. Assim, tive a oportunidade de antes de convidar as gestantes a participar do estudo, de apresentar o projeto ao grupo da Unidade de Cardiologia Fetal.

Vivenciei de fato a gravidade da cardiopatia, quando algumas tentativas de entrevistas não se concretizavam, devido aos óbitos fetais que ocorriam durante a gestação.

As enfermeiras da Unidade de Cardiologia Fetal avisavam-me e compartilhavam as informações quando da chegada das gestantes da filantropia, pelo e-mail do grupo ou até mesmo com ligações telefônicas, a fim de que pudesse iniciar o acompanhamento.

Nessas ocasiões, era apresentada às gestantes e fazia questão de estar com elas, desde a apresentação da Unidade de Cardiologia Fetal até as demais instalações do HCor, para que estivessem cientes por onde deveriam transitar, quando chegassem ao HCor para as consultas, exames ou mesmo por ocasião do nascimento dos seus bebês.

Acompanhava, também, as orientações realizadas pelas enfermeiras coordenadoras/supervisoras da pediatria, as consultas obstétricas e as que conseguiram ter seus filhos no HCor, conforme o combinado, eu as visitava e, sempre que possível, ia até a UTI para trazer notícias dos bebês.

Aprendi muito com a equipe, aprendi como lidar com a gravidade das cardiopatias e a perder o medo de enfrentar a trajetória e os desfechos enfrentados pelos binômios mães-filhos, que fariam parte da minha pesquisa, da minha vida, dos meus pensamentos e sentimentos. Enfrentar o campo foi o meu maior desafio.

Durante o período que antecedia o nascimento dos bebês, algumas das participantes deste estudo ficaram hospedadas em casas mantidas por ONG. Há duas importantes instituições, na cidade de São Paulo, que dão o citado suporte às famílias oriundas de outros Municípios ou Estados, com a finalidade de tratamento de 
crianças com diagnóstico de cardiopatias são elas: Associação de Assistência à Criança Cardiopata (ACTC) e a ONG Pequenos Corações.

A ONG Pequenos Corações é uma entidade sem fins lucrativos, com sede em São Paulo e atuante em todo o território nacional, a qual presta assistência às crianças acometidas de cardiopatia congênita e as suas famílias. Seu principal objetivo é orientar e auxiliar as famílias com crianças cardiopatas, no Brasil, para que as mesmas tenham acesso a tratamento adequado.

A ONG Pequenos Corações foi constituída, formalmente, em fevereiro de 2010, no entanto as ações em prol das famílias dos cardiopatas existem desde 2006 e se iniciou por meio da união das famílias, que se ajudavam mutuamente. Dentre as atividades desenvolvidas por essa ONG destaca-se o esclarecimento e a sensibilização da comunidade e autoridades políticas ligadas à saúde sobre a importância da Cardiopatia Congênita, do diagnóstico precoce e do tratamento adequado, no tempo certo, para a redução da mortalidade. Tem como missão prestar atendimento às crianças portadoras de cardiopatia congênita e suas famílias, informando e proporcionando hospedagem, alimentação e encaminhamento para assistência jurídica, médica e/ou assistencial, bem como desenvolver ações, que visam minimizar o impacto social, financeiro e psicológico que as famílias dessas crianças sofrem durante o tratamento da cardiopatia.

Por ser um grupo de mães de crianças cardiopatas, entendem o quanto a situação das pessoas atendidas é delicada, não apenas com relação ao estado de saúde dos pequenos cardiopatas, mas também no que se refere ao sofrimento emocional a que estão submetidas essas famílias. Procuram em todos os meios de comunicações possíveis organizarem grupos de apoio, onde compartilham experiências e apoiam-se mutuamente, uma vez que o choque da notícia e o sentimento de solidão é a primeira dificuldade que a família com um filho cardiopata enfrenta. Saber que não estão 
sozinhos é de suma importância para enfrentar os desafios que virão: dia-a-dia cheio de imprevistos, cirurgias, dias de UTI e hospitais, entre outros.

A sede da ONG Pequenos Corações conta com o trabalho voluntário de uma psicóloga que atende, individualmente, mães que estão passando por momentos mais delicados, proporcionando seções de grupo semanais e ajudando-as a compreender e reagir de forma mais positiva aos inúmeros acontecimentos difíceis que permeiam a vida das crianças cardiopatas em tratamento.

A ACTC está localizada no bairro Pinheiros, é uma organização da sociedade civil, sem fins lucrativos, fundada em 1994, com a finalidade de prestar atendimento multidisciplinar às crianças e aos adolescentes com diagnóstico de doenças cardíacas. Proporciona hospedagem, alimentação, apoio social, psicológico, desenvolvendo ações que tem como meta transformar a situação-problema em crescimento e aprendizado.

A ACTC considera o apoio extra-hospitalar fundamental para possibilitar o acesso, a continuidade e o sucesso do tratamento às populações em situação de risco social atendidas pelo SUS.

Desse modo, a casa é permanentemente ocupada, recebe anualmente em torno de 500 pacientes. $O$ papel da mãe/acompanhante é a de parceira na organização diária da ACTC $^{53}$.

Na ACTC tive a oportunidade de visitar, juntamente com minha orientadora, o trabalho realizado. Conhecemos a Oficina Maria Maria, onde bordados são realizados pelas mães hospedadas na casa. A coordenadora da oficina, Cristina Maria Macedo Tomaz, apresentou-nos sua dissertação de mestrado intitulada "Memória de Mulheres: lembranças e identidades de mulheres brasileiras da ACTC", cujo objetivo foi o de compreender essas mulheres por meio de suas memórias, identidades, maternidade e trajetórias de vida discutidas nas oficinas de bordados, quando teciam suas histórias vividas nas histórias de seus filhos cardiopatas. 
Os bordados são produzidos e comercializados, não apenas como fonte geradora de renda, mas como contribuição para a construção da ACTC, proporcionando, por meio da arte do bordado, um tempo de transformação pessoal, social e estético para as mães, enquanto esperam os desfechos dos tratamentos de seus filhos ${ }^{53}$.

Como havia decidido que o codinome das participantes deste estudo seriam Estrelas, solicitei à coordenadora Cristina que indicasse uma das mães para que eu solicitasse a realização de um trabalho com oito duplas de estrelas bordadas, representando as mães e bebês, do meu trabalho.

Fui, então, apresentada a senhora Olímpia, avó de uma menina de 12 anos, que foi tratada aos dois meses de uma cardiopatia congênita e que, atualmente,é voluntárias na ACTC. Assim, cheguei à identificação das participantes com o bordado dessa senhora, que encantada com a minha proposta escolheu diferentes pontos, que nominam as participantes/bebês.

O codinome Estrela originou de conversas com as gestantes, nas quais alguns temas eram recorrentes - o medo da perda, o futuro dos bebês e eu procurava além de respeitar suas escolhas religiosas/espirituais, refletir com elas o "para quê" (significado) e não o "porquê" (culpa) delas serem mães dessas crianças. Talvez, na tentativa de mitigar o sofrimento dessas mulheres, comecei a pensar e a me referir a elas e aos bebês como "Estrelas".

Essa ideia de que as participantes teriam "Estrela", por codinome, concretizou-se quando fui apresentada à autora do livro "Mãe de UTI Amor Incondicional", Maria Julia Miele. Nessa ocasião, conversamos muito sobre sua filha, chamada Sofia, que já havia morrido há 11 anos, devido a uma cardiopatia grave. Contei-Ihe sobre o meu trabalho, ela contou-me sobre sua história, e de como, atualmente, ajuda mães de bebês cardiopatas. Discorri sobre minha vontade de colocar nome de Estrelas para identificar as participantes do meu estudo; nesse momento ela pegou uma folha de papel sulfite em branco e começou a fazer dobraduras, dizendo que estas eram 
marcas de sofrimento que uma mãe passa, quando tem uma longa trajetória com seus filhos em hospitais e UTIs e por fim ainda os perdem. Com uma tesoura cortou a dobradura que havia acabado de fazer, transformando-a em uma Estrela e me entregou; para mim isso foi emocionante, tive certeza de que as participantes seriam mesmo Estrelas.

Percebi, também, como as mães tornam-se solidárias umas com as outras, principalmente, as que não eram da cidade de São Paulo. Certa vez, ao visitar a Estrela 2, que estava internada por causa do nascimento de seu bebê, encontrei a Estrela 1, como acompanhante da Estrela 2; fiquei muito feliz de vê-las juntas. Nesse dia, solicitaram que eu fosse à UTI Neonatal para ver o bebê; de E2 que havia nascido. Ele era muito lindo, chorava alto e pesava mais de três quilos. Como os médicos estavam fazendo um eletrocardiograma; eu não me senti à vontade para tirar fotografias, mas voltei para dar notícias.

A partir daí vínculos foram estreitando-se e eu passei a ser uma pessoa de referência para elas, e isso se manteve até hoje. Os meus colegas compartilham momentos das histórias dos bebês, quando eles voltam para o retorno ao ambulatório, eu os acompanho pela rede social e, também, mantenho contato com as que perderam os bebês. Houve uma mãe que me pediu para procurar outra mãe (que não fazia parte do meu estudo) para conseguir as fotos do seu bebezinho que já havia falecido. Assim que as consegui, enviei a ela.

Esse fato me fez lembrar de uma aula que assisti do Professor Adib Jatene, aos residentes do HCor, intitulada "A cirurgia que eu vivi', por ter sido uma fala intensa, durante a qual jovens médicos tiveram a oportunidade de refletirem sobre o que é ser médico, e ao término o citado professor discorreu sobre os avanços tecnológicos na cirurgia cardíaca, mas deixou como mensagem que todos os médicos ali presentes tinham que lembrar que o diferencial estava no atendimento humanizado, que eles tinham que ser tão 
competentes que mesmo que se seus pacientes fossem a óbito, que a família tivesse a certeza de que o atendimento recebido havia sido o melhor e seria grata por isso. No meu contato com as mães que perderam os bebês este era o sentimento.de gratidão.

Cada uma das participantes com suas características: as adolescentes mais otimistas demoravam mais para apreender a gravidade do que estava por vir; as mais maduras, mais atentas a todos os movimentos da equipe de saúde, mais questionadoras e mais vigilantes.

Minha experiência prévia em UTI Pediátrica e Neonatal, vivenciada em outros hospitais, não minimizava o impacto do encontro ao visualizar o estado dos bebês. Eu não procurava ficar vendo prontuários, eu apenas observava o movimento da equipe das mães e era por meio das mães que eu tinha informações dos boletins médicos; muitas vezes temia o desfecho, enganei-me várias vezes; aqueles casos que eu considerava complicados foram os com melhores desfechos, e outros que não me impressionavam tanto, que eu ficava mais otimista, foram aqueles de quem eu recebi a notícia da morte; notícias essas que chegavam de maneiras distintas, por outras mães ou pela equipe.

A minha torcida pela vida dos bebês era grande, por eles e pelos pais, por mim, pela equipe dedicada; a cada bebê que perdíamos era uma grande "derrota" para a equipe. Muitas vezes, nas reuniões da equipe, eu levava algum relato das minhas entrevistas, como uma forma de motivação, para melhorar cada vez mais. Se essas crianças chegaram até nós é para a evolução do nosso serviço.

Conheci os companheiros das participantes e alguns as acompanhavam até a Casa 4, onde aconteciam as entrevistas. Muitas vezes, nas idas à UTI para visitar os bebês, encontrava os pais e conversava sobre a evolução dos bebês.

Outra ocasião que me lembro em que fui visitar, uma das participantes na Unidade de Internação, o pai, que acompanhou o 
parto, relatou a felicidade de ver seu filho, o amor que sentiu, me senti privilegiada por compartilhar esses momentos especiais da vida deles e observava o quanto essas falas fortaleciam o vínculo entre o casal, essas crianças com certeza uniam essas famílias.

Observava, também, como elas se comportavam com as questões da religiosidade e da fé, às vezes chegava até o leito da UTI e encontrava o bebê dormindo e elas agarradas à bíblia. Cada uma delas com sua crença e com a esperança de total recuperação de seus filhos.

Em geral os companheiros ficavam sempre muito contentes quando me encontravam, houve um que perdeu sua mãe enquanto sua filha estava na UTI, e eles (o casal) disseram-me que ela havia trocado sua vida pela da neta. Por ocasião da internação para o segundo estágio da cirurgia, da bebê encontrei os dois com a camiseta da ONG Pequenos Corações, a bebê bem cuidada, eles muito felizes e ele com uma tatuagem enorme no braço com o nome da sua falecida mãe; conversamos sobre a morte de uma maneira tranquila. Queriam saber da pesquisa, pediram para ler, novamente, a narrativa.

Nesse processo todo, com as adversidades, nunca os tratei como vítimas; convivi e percebi que essas mulheres e seus companheiros gostavam de ser escutados por mim e pela equipe; sempre ressaltavam a importância da consulta com a psicóloga. $\mathrm{Na}$ verdade eles sentiam-se muito acolhidos quando alguém os escutava.

Era muito interessante como elas gostavam de suas histórias, quando realizava a conferência das narrativas com elas, o quanto elas refletiam e consideravam-se importantes, afinal eram suas histórias escritas ali. Uma das mães adolescentes ficou tão feliz que falou "Nossa, é a minha história...Isso me dá vontade de voltar a estudar"; isso me motivou a levar-Ihe um livro de presente, que ela leu e me disse que fora a primeira vez que conseguira ler um livro inteiro. Seu bebê estava na pediatria e nos retornos ao ambulatório 
contou-me que toda a família já havia lido o livro. Essa participante , também, me informava de alguns atendimentos nossos não tão bem encaminhados; eu comunicava estas questões para a Coordenadora do Projeto, que tomava as medidas pertinentes; isso se dava em geral após a alta do hospital, no acompanhamento ambulatorial.

Quando os bebês recebiam alta, as mães me avisavam e sempre levava uma lembrancinha e as fotos que havia tirado.

Algumas vezes, tivemos a oportunidade de conversar com os casais sobre os bebês que não sobreviveram e, quando entrávamos na seara da espiritualidade, alguns falavam em outras vidas, que "estava escrito que seria assim". Mas isso não diminuía a minha responsabilidade com as melhorias do nosso serviço; poderíamos até perder nossos bebês, mas não por falha nos nossos processos e fluxos de retorno ao serviço. Esses assuntos eram sempre compartilhados nas reuniões de equipe com muita sinceridade, tranquilidade e transparência.

A convivência com esses casais e algumas vezes, com as perdas dos seus filhos levou-me, inevitavelmente, à reflexões sobre o meu papel no grupo, sobre a forma de encarar a morte não só as dos bebês, mas a nossa própria, levando-me a pensar se temos uma programação existencial, ou seja, se ao nascermos temos algo específico a realizar durante o período em que vivemos, e se de fato temos, qual seria essa programação? Se este trabalho faz parte do meu aprendizado pessoal, como me fortalecer para realizá-lo e não esmorecer perante as dificuldades que se apresentavam.

Dessa forma, matriculei-me em um curso de Assistenciologia, intitulado "Qualifique sua competência interassistencial," no qual minha intenção foi capacitar-me para enfrentar a possibilidade dos bebês não sobreviverem e ainda assim encontrar um sentido da vinda deles por tão pouco tempo nessas famílias. Encontrei no paradigma consciencial os conceitos de multiexistencialidade e de que no ciclo evolutivo de cada consciência, ou de cada um de nós, as situações e circunstâncias que nos ocorrem têm uma razão de 
ser, contribuindo para nosso amadurecimento e crescimento pessoal. Percebi, nesse momento, que a religião não me proporcionaria explicações suficientes para lidar com a essas famílias, embora mantivesse sempre o respeito por suas crenças e valores.

\subsubsection{Entrevistas}

A fim de produzir melhores condições para as entrevistas, o local escolhido é fundamental, devendo-se sempre procurar um ambiente calmo, privativo e acolhedor.

Nessa perspectiva, a maioria das entrevistas foi realizada em uma sala da Casa 4, local da filantropia, onde está sediado o Núcleo de Pesquisa Qualitativa do HCor e outras foram realizadas na unidade de internação do $6^{\circ}$ andar.

As entrevistas foram semiestruturadas (APÊNDICE B), as quais ocorreram em dois momentos: primeiro momento enquanto gestantes, com as seguintes questões norteadoras:

$\checkmark$ Como foi para você ter recebido o diagnóstico de cardiopatia de seu filho?

$\checkmark$ Como foi a sua vinda ao HCor?

O segundo momento ocorreu após o nascimento dos bebês respeitando a disponibilidade das puérperas e a permanência dos bebês no HCor. Nessa oportunidade, as questões de entrevistas foram:

$\checkmark$ Como você foi recebida pela equipe de saúde do HCor?

$\checkmark$ Como foi sua experiência no HCor?

Para a operacionalização das entrevistas, segui as três etapas preconizadas por Meihy ${ }^{49}$ : durante a pré-entrevista foi possível 
estabelecer o entendimento preparatório para que as gestantes/puérperas tivessem a exata noção do âmbito da sua participação; nessa ocasião solicitava a autorização para utilização do gravador e realizava o agendamento das entrevistas conforme a disponibilidade das participantes.

Dessa maneira, conforme relatado, as 16 entrevistas foram realizadas no HCor e tiveram duração de 30 a 60 minutos, seguindo o roteiro das questões norteadoras.

As entrevistas foram gravadas e transcritas na íntegra pela pesquisadora, sendo necessário ouvir, reiteradamente, o material gravado, para que pudesse transformar a linguagem oral em escrita e ser fiel às narrativas. Foram retirados os excessos e os vícios de linguagem, para que houvesse a fluência do texto. As dúvidas e os períodos de silêncio foram assinalados no texto por reticências e algumas observações colocadas em colchetes.

A etapa seguinte foi a da textualização, onde as perguntas foram retiradas do texto e incorporadas às repostas, nesse momento o texto passa a ser de domínio do entrevistado, assumindo a primeira pessoa da narrativa. Assim, palavras-chaves e ideias centrais começaram a emergir. E, finalmente, a transcriação, onde o texto foi recriado em sua plenitude ${ }^{49}$.

A conferência das entrevistas com as participantes foi um momento de extrema importância tanto para as participantes como para mim, visto que elas demonstravam encantamento e o reconhecimento de suas histórias, validando-as quase sempre na íntegra.

O diário de campo foi, também, uma estratégia empregada na coleta dos dados, estando sempre presente, por meio de minuciosos registros em um caderno que me acompanhava, quando as gestantes visitavam o cenário do estudo, durante as entrevista, anotando suas impressões e expectativas. Anotava, ainda, quando as visitava na Unidade de Internação, como estavam os bebês na UTI, depois na pediatria e nos retornos ambulatoriais. 


\subsection{A organização e a análise dos dados}

A organização dos dados etnográficos envolve a observação participante ou imersão no cenário, entrevistas e interpretações de padrões culturais pelos pesquisadores ${ }^{54}$.

Os dados deste estudo foram coletados e analisados simultaneamente, buscando os eventos significativos extraídos das narrativas.

A pesquisa qualitativa depende da apresentação sólida e descritiva dos dados. Assim o pesquisador tem a possibilidade de conduzir o leitor a uma compreensão do significado da experiência estudada. Essas etapas encontram-se detalhadas nos capítulos $5 \mathrm{e}$ 6.

A análise interpretativa dos dados foi desenvolvida em níveis crescentes de complexidade, possibilitando a sistematização das categorias culturais.

Durante a análise dos dados considerou-se a relevância de se verificar o significado e as perspectivas das participantes do estudo, as relações de estrutura, ocorrências e distribuição dos eventos e pontos de tensão da narrativa. 

CAPÍTULO 5

NARRATIVAS, VIVÊNCIAS E SENTIMENTOS DAS

PARTICIPANTES

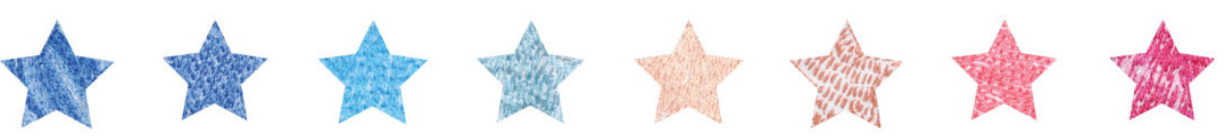





\begin{abstract}
"Ouvir aqueles que sofrem é uma tarefa árdua para o ser humano, particularmente quando o ouvinte é uma pessoa sadia. Suas vozes remetem às condições do corpo que revelam a nossa própria vulnerabilidade. Suas palavras são fáceis de serem ignoradas, pois, frequentemente são articuladas fora da cadência e trazem mensagens conflitantes. No entanto, ouvir é um ato fundamentalmente moral e demanda uma atitude ética de ouvir por parte de outro ser humano. Ao escutar o outro escuta-se a si mesmo e cristaliza-se o compartilhar de necessidades de cada um pelo outro". [Arthur Frank]
\end{abstract}

Neste capítulo são apresentadas as narrativas - das oito participantes deste estudo.

A opção pela narrativa ocorreu em virtude da possibilidade de se compreender a vida no tempo, de se obter o significado dos eventos e do quanto às ações das pessoas auxiliam no processo de formação de sua própria história. Tentamos entender quem essas mães estão se tornando em decorrência do que elas viveram ${ }^{55}$.

As histórias das gestantes/puérperas registradas nesta investigação, cujas narrativas obedecera à sequência temporal e causal dos eventos, constituíram a tentativa de entendê-las em sua concretude, clareando e interpretando ações e acontecimentos do seu mundo interior e exterior e, desse modo, tornando-se tão significativas para elas como para seus interlocutores ${ }^{56,57}$.

As etnografias tradicionais incorporam relatos na primeira pessoa e são entendidas como descrições realísticas, mas diferem somente no formato das outras descrições científicas. Mesmo que a maneira de escrever varie, a história escrita é o evento, e não a história que os informantes criam sobre ele $^{58}$.

Nesta pesquisa, a partir de histórias gravadas, as falas foram recortadas privilegiando o que se encaixava no tema pretendido. Há decisões sobre a forma, ordem e estilo de apresentação: são fragmentos da vida que se obtém nas entrevistas que serão descritas. A resposta antecipada ao trabalho, inevitavelmente, molda o que é incluído ou excluído. No final, o pesquisador elabora uma 
pós-história, apontando o significado das narrativas, editando e reconstruindo o que foi dito ${ }^{59}$.

Os gêneros da narrativa com seus estilos e estruturas distintos são modos de representação que o narrador escolhe baseado nas suas intenções. As histórias descritas em conversações dividem parâmetros comuns, embora elas devam ser colocadas juntas, em formas contrastantes e, como resultado, apontar diferentes interpretações. Os eventos tornam-se significativos devido a sua colocação dentro de uma narrativa $^{59}$.

Cabe salientar que as histórias modelam as ações, porque incorporam os motivos que as desencadeiam, nos quais se incluem os motivos intensos, as aspirações vagas, as intenções claras e as metas definidas ${ }^{60}$.

A narrativa é considerada uma forma de organizar episódios e fatos das ações. É uma conquista que congrega os fatos do cotidiano, do tempo e do lugar. A narrativa permite a inclusão das razões dos atores para os seus atos, bem como as causas do acontecimento. As interpretações analíticas são parciais, verdades alternativas que têm por objeto a crença e não a certeza para o aumento do entendimento muito mais que o controle. Os analistas da narrativa, na prática, alcançam essa questão da verdade de maneira diferente. Alguns assumem que a linguagem representa a realidade. As narrativas requerem interpretação; elas não falam por si só, ou fornecem um acesso direto ao tempo, a lugares ou a culturas ${ }^{61}$.

As narrativas das oito Estrelas, participantes deste estudo, remete-nos ao imponderável da vida. Salvar a vida de seus bebês eis o que importa, eis o que é determinante para suas existências, desde o momento em que ficam cientes da doença de seus filhos. Nada se torna mais imprescindível do que a sobrevivência dessas crianças. Essas mulheres alimentam-se de esperança, apostam na cura, aceitam com altivez sua cota de infortúnio. Movem-se no fio da 
navalha, no tênue limite entre a esperança de criar seu filho e sua perda irremediável.

Os nove meses de angústia e esperança são apenas o início de uma longa trajetória de incertezas e lágrimas, de dores e alegrias. O pêndulo ora lhes dá o sonho de vê-los crescer, ora lhes tira a âncora. E essas mães deixam a casa, deixam os outros filhos, viajam milhares de quilômetros para uma cidade imensa e desconhecida, com o temor latente do inusitado que as aguarda. Feliz o dia em que saem do HCor com seus filhos nos braços, imensa a dor de quem ao fim da batalha entrega resignada seu tesouro a Deus.

Eis aqui as narrativas dessas oito corajosas guerreiras, que lutaram durante meses e continuarão lutando para ver o crescimento de seus filhos, embora com as dificuldades inerentes à doença. 



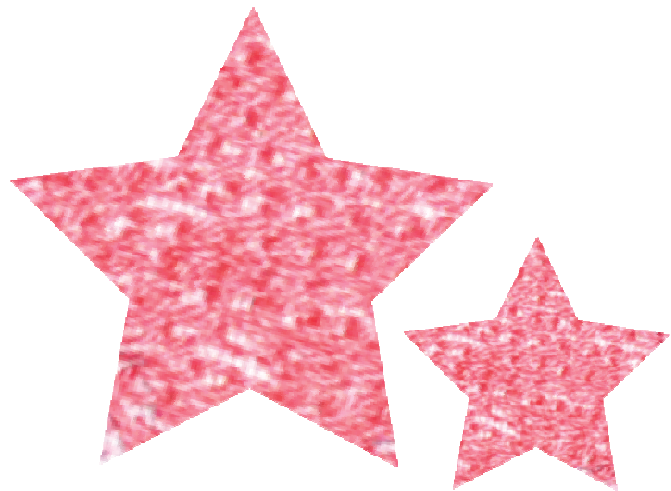

E1 tem 29 anos, ensino superior incompleto, natural de Costa Rica (MS), é casada e é evangélica. Sempre teve vontade de ser mãe, como não conseguia, adotou seu primeiro filho, um menino, e sete anos após descobre estar grávida de uma menina. 



\section{Data: $15 / 8 / 2012$}

\section{Horário: 16 horas}

"Esta gravidez, na verdade, não era esperada. Fiquei grávida de gêmeos há 11 anos, mas perdi os bebês e não consegui mais engravidar. Fiz tratamento para engravidar, mas não era o que Deus havia preparado para mim. Ele preparou um menininho que eu adotei e que hoje tem sete anos. Mas agora aconteceu e estou esperando uma menina.

Eu casei muito nova, tinha 16 anos, meu marido também era bem novo, mas a gente está junto até hoje. Como não conseguimos ter um filho nosso, a gente resolveu adotar.

Meu marido é caminhoneiro e, em 2005, fiquei três meses viajando com ele, quando minha sogra nos ligou avisando que havia um bebezinho para adoção na minha cidade, um menino, mas a gente queria uma menina.

Resolvi voltar para minha cidade para conhecer o bebê, pensando que iria, apenas, para conhecê-lo. Entretanto, quando cheguei, todo mundo me falou que o bebezinho havia sido muito maltratado pela mãe.

Então, fui conhecer o meu menino, que estava em um abrigo da Prefeitura. Ele tinha três meses, era bem pequenininho, pesava uns quatro quilos, bem moreninho, encardido de carvão, de olho azul. Ele estava em um bercinho todo sujo, porque lá não era um abrigo só para crianças, era uma casa improvisada, onde a Prefeitura colocava as crianças abandonadas. Ele estava com a roupinha bem surrada, bem velha. Ele era uma criança quieta, não sorria para ninguém, parecia que tinha medo de tudo. Aí, quando eu olhei para ele, eu falei que era ele que Deus havia preparado para mim, que estava me esperando. Na hora em que o coloquei no colo, ele veio assim se agasalhando, olhou para mim e abriu um sorriso.

Naquele momento eu disse que ele iria para casa comigo, assim que fosse possível. Foi quando começou toda a batalha para 
a adoção. Eu falo que o menino nasceu mesmo a partir daquele instante, porque lutei nove meses para levar ele para casa. Fui atrás de advogado para saber o que devia fazer para adotar e ele me encaminhou para a promotora, para entrar na fila de adoção. Pode ser que dê certo, pode ser que não, disse ele. Mas desde o comecinho eu tinha convicção de que tudo ia dar certo.

Quando fui conversar com a promotora, ela foi muito rígida comigo, perguntou minha idade, eu tinha 22 anos, aí ela me falou que eu não tinha muita chance de levar ele para casa e me disse: é menos de $1 \%$ a chance que você tem de adotá-lo, então ele ainda não é seu.

Nesse mesmo dia, liguei para o meu marido, que ainda estava viajando e disse que havia conhecido o menininho. No começo ele ficou meio em dúvida, porque a gente queria uma menina. Eu falei para ele continuar a viagem normalmente e, quando ele voltasse, que a gente ia conhecer o menino; e se ele achasse que não havia tocado seu coração, eu abriria mão dele. Ele demorou uns vinte dias para chegar e então a gente foi visitar o nenê. Quando a gente chegou ele estava dormindo. Meu marido olhou para ele e pediu para a moça para pegá-lo e, quando pegou o menino no colo, ele falou: deixa a menina, depois a gente corre atrás de ter uma. Agora é a vez do menino.

Aí começou a batalha. Como ele foi uma criança muito maltratada, demorou a andar e a sentar. Eu ficava muito preocupada, porque com sete meses as perninhas dele eram bem fininhas e não tinham movimentos. Era uma criança que do jeito que você colocava ele ficava. Então pedi para levar ao pediatra, que o encaminhou para fisioterapia, e me disse que se não resolvesse ela daria outro encaminhamento. Aí eu tinha horário para tirar e devolver para o abrigo; a fisioterapeuta me ensinava o que precisava fazer com ele. Na sétima sessão, ele já estava sentando, mas todo dia eu ficava com ele, para que ele melhorasse logo. 
A gente foi tratando e aí ficou aquela criança linda, perdeu aquele encardido, aquela sarna, nasceu o cabelinho, ele era careca. E finalmente o menino pôde ir para nossa casa.

Por isso tudo é que eu não esperava ficar grávida. Ainda nessa época houve um surto de virose na nossa cidade e até o menino ficou doente. Ele foi para o hospital, ficou uma semana, e eu cuidando dele. Depois que ele melhorou, eu comecei a passar mal.

Eu sentia muita fraqueza e, no hospital, o médico nem pediu exame de gravidez porque conhecia meu histórico, ele achava que fosse virose. Fiquei internada e tomei um monte de remédio para a virose e não melhorava. Ele me mandou para casa e eu não melhorava, aí falei para meu marido comprar um teste de gravidez e pensei: quem sabe é alguma coisa. Fiz o teste e deu positivo. Ao mesmo tempo deu susto e deu medo, porque eu havia tomado muito remédio. Então voltei ao médico e ele pediu um exame de sangue, para confirmar; fiz o exame de sangue e o ultrassom, deu mesmo positivo. Comecei o pré-natal e ele pediu para eu ficar de repouso por causa do diabetes.

Sou diabética desde os 14 anos, tomo insulina duas vezes por dia. Daí eu fui fazendo o pré-natal, ficando em repouso. Quando chegou a hora de fazer o ultrassom morfológico, o médico achou que havia uma alteraçãozinha no coração do nenê, ele achou que o coração estava muito grande. Fui para o ginecologista e ele me encaminhou para um médico em Campo Grande.

Em Campo Grande fiz eco e ele achou que era um caso que preocupava e que precisava de mais cuidado. Pediu quatro semanas para conseguir um encaminhamento para algum lugar onde houvesse recurso, porque era um tratamento muito caro, era um tratamento de risco. Ele falou que havia duas equipes no Brasil que podiam cuidar do meu nenê, uma em Curitiba e outra em São Paulo. Ele ficou de ver qual equipe aceitava pegar meu caso pelo SUS. Aí Deus foi tão maravilhoso que no outro dia, de manhã, a secretária 
dele ligou avisando que havia conseguido em São Paulo, com uma doutora do HCor, que era para eu me ajeitar para viagem.

O médico lá de Campo Grande não chegou a falar certo o que estava acontecendo com o nenê, acho que é porque ele não era especialista, só falou para mim que havia uma alteração no coração. Eu já estava preocupada pelo ultrassom, aí ele falou que era para eu ficar tranquila, que os médicos iam fazer tudo o que fosse possível.

Assim mesmo fiquei bastante preocupada, porque eu havia levado a gestação normal até aquele dia e ele falou que podia ser que não fosse mais para frente, podia ser que o bebê falecesse dentro da minha barriga, antes de conseguir o socorro. Mas, no outro dia, já veio a resposta do tratamento aqui em São Paulo, aí já fiquei mais aliviada e pensei que Deus estava sendo tão maravilhoso, que fez descobrir a tempo e havia me encaminhado para o lugar certo.

A gente não conhecia nada aqui em São Paulo, não tinha família, não sabia de nada, daí fiquei preocupada. Como vou fazer lá, não conheço nada, vou chegar lá e vou ficar perdida, eu pensava. $E$ todo mundo me falava que São Paulo era uma cidade perigosa, que ninguém ia me ajudar, que ninguém me conhecia. Então, a minha mãe, que trabalha na Prefeitura, comentou com o chefe dela que Ihe disse que tinha parentes em São Paulo e que ia ligar pedindo ajuda.

Então a gente ficou conhecendo essa família quando chegou aqui. Eles nos ajudaram. Minha mãe não pôde vir comigo. Ela ficou cuidando do nosso filho, de um irmãozinho meu de seis anos, que também é adotado, e de mais dois sobrinhos. Minha sogra veio comigo, conseguimos uma ambulância para vir e viajamos 1.000 km até chegar a São Paulo.

Como eu disse tudo começou em Campo Grande. O médico de lá ligou para a equipe daqui e, quando a gente chegou, liguei para a médica do HCor, que pediu que na sexta-feira de manhã eu já fosse 
com a sacola para o Dante Pazzanese. Fui até lá e ela passou tudo que tinha que fazer e me encaminhou para o HCor.

A doutora fez um exame bem detalhado e confirmou que havia problema mesmo no coração da bebê e que era grave. Ela falou que a veinha do coração da bebê que vai para o pulmão saía normal, mas a que ia para o corpo estava forçando, por isso a nenê já estava sofrendo, criando muito líquido na sua barriga e já entrando um pouquinho de líquido no pulmãozinho dela.

Então ela falou que precisava fazer o procedimento o mais rápido possível, senão o risco ia ser cada dia maior. Ela falou que não podia dar $100 \%$ de certeza. Explicou que eles estavam com um projeto novo para cuidar dessas crianças e que da quantidade de crianças que já haviam vindo para cá, ela havia perdido um bebê só. Mas pelo estado da minha bebê, ela estava muito confiante. Nesse dia, ela fez todas as medidas das veinhas do bebê e disse que eram perfeitas e que por isso ela acreditava que não haveria complicação.

Nossa, foi um alívio muito grande, muito bom, porque consegui ficar bem tranquila. Ela falou que quanto mais tranquila eu ficasse, mais sossegada a nenê ia ficar e isso ia ajudar no procedimento.

A gente pediu bastante oração para o pessoal lá da cidade, todas as igrejas fizeram corrente de orações. As pessoas ligavam perguntando que dia seria o procedimento para rezar. Claro que isso me passou uma segurança maior, porque confio muito em Deus, e tinha certeza de que Ele estava do meu lado, estava comigo e pedi muito: Senhor, coloca tuas mãos em cada pessoa que está me atendendo, cada pessoa que está cuidando da bebê, guia a vida de cada um, as mãos, a inteligência, a mente de cada pessoa, para que corra tudo bem.

Os médicos iam colocar uma válvula que precisava passar pelo furinho da barriga. Essa válvula ia passar pelo cordão umbilical e ia até a veinha da nenê, que estava entupida e ia encher um balãozinho. Quando o balãozinho enchesse, a veia ia desentupir e eles iam tirar o balãozinho para que o coração voltasse a bater 
normal, porque um lado, como estava muito forçado, estava grande, mas ele já tinha musculatura para voltar ao tamanho normal. Era isso que os médicos iam fazer, só que na hora do procedimento eles tiveram que tirar a água do pulmãozinho dela também, porque estava com muita água e aí foi preciso tirar na mesma hora, porque ela não aguentaria esperar outro dia.

Quem fez o procedimento foi a médica e a equipe do HCor, havia mais de dez pessoas na sala de cirurgia. Eu entrei às $8 h 45$ e saí 1 h30 da manhã do outro dia, porque na hora que aconteceu o procedimento a medida que a doutora havia feito, havia mudado, parece que não havia a agulhinha aqui no hospital e precisaram ir buscar em outro hospital, então precisaram aumentar a anestesia, por isso que demorou.

Quando acabou o procedimento a doutora me disse que estava tudo bem, que a bebê estava bem, que era para aguardar amanhã, para ver como ela ia reagir, como ela ia se recuperar. E quando eu vim para o quarto, acho que às 5 horas da manhã, ela já se mexeu dentro da minha barriga e eu fiquei bem mais tranquila, porque eu estava ainda sob efeito da anestesia e não sentia nada, daí ela mexeu logo e isso me mostrou que ela estava se recuperando bem.

Agora é só esperar a alta. Acho que vou ter alta na sexta-feira, aí vou fazer o acompanhamento de pré-natal de risco em Campo Grande e volto para os retornos aqui. A médica do HCor vai marcar a data do parto, que tem de ser feito aqui, deve ser em novembro.

Quando a data for marcada, vou chegar uns dez dias antes, para ver se está tudo bem. O parto vai ser feito aqui em São Paulo, porque quando ela nascer vai ser preciso fazer outro procedimento e eu devo ficar mais um tempo aqui, mas acho que já vai ser mais fácil.

Sabe a gente não pode desistir, tem que entregar na mão de Deus, porque se Ele preparou tudo... é para a gente." 


\section{Data: 15/10/2012}

\section{Horário: 14 horas}

“Em Campo Grande continuei o pré-natal e não passei mal e nem precisei ficar internada. No dia 19 de setembro, eu voltei aqui para São Paulo, porque tinha retorno e o obstetra disse que ia marcar o parto para o dia 8 de outubro e que era para eu voltar para Campo Grande e ir passando uma vez por semana no médico até a hora de voltar para São Paulo.

No dia $1^{\circ}$ de outubro, no retorno da semana com o obstetra lá de Campo Grande, ele achou melhor que eu fosse para São Paulo. Ele falou que achava melhor adiantar a viagem porque já estava começando a ter dilatação e que eu já estava tendo algumas contrações... Como eu estava muito longe, entrei em contato com a equipe do HCor e eles acharam melhor que eu viesse.

Saí de lá no mesmo dia e foram 12 horas de viagem, vim de ambulância com a minha mãe e com uma enfermeira. O médico pediu para a enfermeira me acompanhar por causa da dilatação que eu estava apresentando e pediu que se eu entrasse em trabalho de parto para entrar na primeira cidade do caminho. Mas graças a Deus vim tranquila, não senti dor.

A médica do HCor estava me esperando. Eu cheguei por volta das 5 horas da manhã e já fiquei direto no hospital. Às 9h30, ela fez o eco e estava tudo bem com a nenê, só que a minha glicose deu uma descompensada por causa da viagem. Então ela conversou com o obstetra e achou melhor eu ficar internada para controlar a glicose.

A bebê nasceu no dia 5 de outubro de 2012. Nesse dia, eu ia ter alta, porque o diabetes já estava controlado, mas ela resolveu que queria nascer. Foi cesariana. Na verdade, não estava sentindo dor, nem estava com muita contração. Só que naquela noite eu tive um pouco de desconforto para dormir e pela manhã tive tontura, minha vista escureceu. Chamei a enfermeira, que entrou em contato 
com o obstetra; ele pediu para eu ficar em jejum e em repouso. Às $12 h 12$ minha filha nasceu.

Os obstetras me acompanharam do quarto para o centro cirúrgico... A psicóloga, também, estava lá. Ela nasceu com uma volta bem forte do cordão no pescoço, faltou um pouco de ar para ela, eles não queriam que ela sofresse para nascer, mas acho que isso fez ela sofrer um pouco. Estava todo mundo lá, a equipe da UTI já estava no centro cirúrgico e foi graças a isso que ela conseguiu sobreviver. Às $16 h 30$ a nenê voltou para o centro cirúrgico, porque eles precisaram fazer um novo procedimento nela. Depois disso, a recuperação dela vem sendo devagarinho, é um passinho por dia. Graças a Deus ela está bem, ainda não houve nem um dia em que tendo chegado aqui no HCor me falaram que o quadro piorou ou que houve alguma intercorrência. Há dias que a gente chega e eles falam que está do mesmo jeito de ontem, mas já é uma vitória, porque não piorou.

Então há dias que eu não consigo chegar cedinho, chego mais ou menos na hora do almoço e fico até depois da visita das 20h30, mas a equipe que está cuidando dela é bem dedicada, fica ali o tempo todo, eu posso ter acesso, só quando há um procedimento é que eles não deixam entrar. Eles são muito dedicados e muito cuidadosos.

Eu sempre pego o boletim das $17 \mathrm{~h} 30$, porque de manhã nunca consigo chegar na hora, o médico vem e conversa, explica os resultados dos exames. Eu não pego muita coisa porque é muita informação, às vezes a cabeça parece que vai dar um branco. Houve um dia em que o médico estava explicando o que estava acontecendo e fiquei olhando, me deu um branco na cabeça. Aí ele perguntou se eu havia entendido e eu disse que não. Então ele me explicou tudo de novo.

Mas graças a Deus ela está caminhando, ela estava bem inchada e de ontem para hoje o rim dela começou a funcionar melhor, ela começou a fazer mais xixi, desinchou bem, a cabecinha 
dela estava muito inchada. Hoje ela já teve uma melhora muito grande e agora ela já está sem sedação desde ontem, está totalmente sem sedação, ela é preguiçosa para acordar.

Ela está reagindo bem ao tratamento, ela não gosta quando apertam o peitinho, que ainda está com o curativo do dreno. O corte da cirurgia está cicatrizado, já tiraram os pontos e agora só falta tirar o dreno.

A médica do HCor me explicou que ela tem SHCE, que ela já fez a valvuloplastia, ela fez outro procedimento chamado cateterismo e outro que eu não lembro o nome. E na semana passada ela colocou um stent. A doutora falou que o lado esquerdo dela, quando fez o procedimento híbrido, já estava voltando a funcionar porque não parou totalmente, ficou cansado só e que ele estava voltando a ajudar, só que não podia esperar voltar totalmente sozinho, tem que ajudar porque ela chegou a um ponto que estabilizou e parou, e ela falou que não pode deixar parar do jeito que está, porque ela não vai ganhar peso, não vai crescer, não vai desenvolver. Então disse que ia fazer outro procedimento híbrido e fez e deu tudo certo, o coraçãozinho dela está se mantendo sem droga e o lado esquerdo está funcionado mais, então pode ser que talvez agora só precise fazer a correção do stent com 6 a 9 meses. É só trocar o stent, mas cada criança tem o seu tempo, o pediatra disse que o dela é devagarinho.

Agora é esperar. A equipe atende a gente muito bem, não há diferença entre ela, que é da filantropia, e o particular ou pelo plano, todo mundo é igual, passou aquela portinha ali (aponta a porta da UTI) é todo mundo igual. A gente vê criança que ficou na UTI muito tempo e que depois volta para visitar a equipe e a gente vê a felicidade dos médicos e dos enfermeiros, e sai todo mundo lá da UTI para ir à recepção para ver as crianças que eles cuidaram. Elas vêm com uma vidinha normal, brincam, correm. Eu tenho essa preocupação, se ela vai conseguir ter uma vidinha normal depois, se ela não vai se sentir excluída das outras crianças. Tem uma mãe 
que ficou um ano aqui, quase um ano com a criança e agora veio fazer a última cirurgia e ela contou que o menininho dela começa a correr, começa a brincar e quando ele mesmo percebe que ele está cansado, ele para de falar, senta e descansa um pouquinho e logo começa a correr de novo, a brincar. É isso que a gente espera para a minha menina também, que ela consiga levar essa vidinha de brincar, de correr, de fazer bagunça."

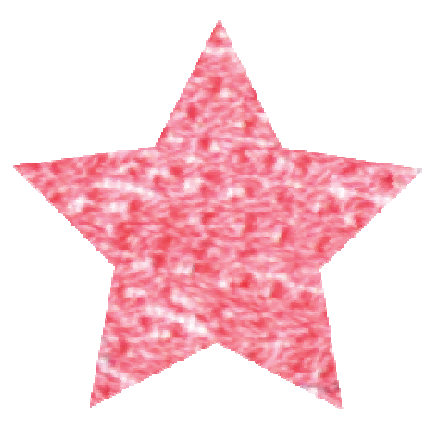

Bebê da E1 recebeu alta no dia 29 de janeiro de 2013, com três meses e 24 dias de vida, pesando $3.585 \mathrm{~kg}$ (peso do nascimento: $2745 \mathrm{~g}$ ), com boa evolução das cirurgias cardíacas realizadas e com reabilitação física adequada para sua idade.Com retornos ambulatoriais agendados no HCor. E1 estava radiante em ir para casa com sua bebê, após tantos dias de internação. 


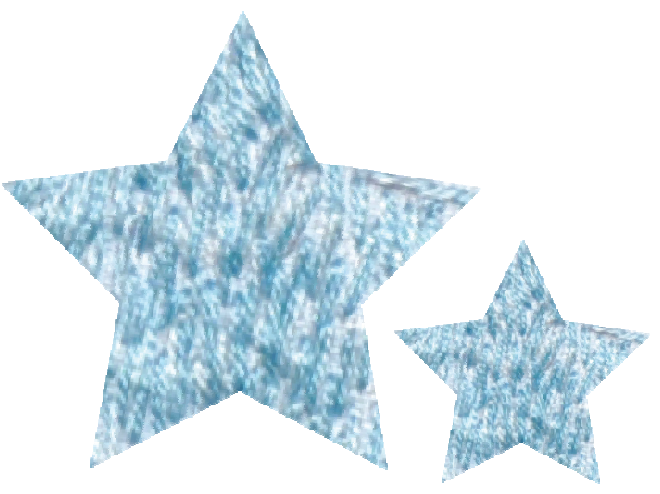

E2 tem 28 anos, estudou até a $5^{a}$ série do ensino fundamental, é natural de Rio Tinto (PB), é casada e é católica. É mãe de cinco filhos, quatro meninas e um menino. Acredita que esta gravidez tenha sido "um presente de Deus". 



\section{Data: $7 / 12 / 2012$}

\section{Horário: 12 horas}

"Minha vida toda foi dedicada a cuidar de crianças, desde os 12 anos, eu tomo conta dos filhos das vizinhas, é cuidar, é dar banho, é arrumar. Sempre falava que tinha a maior vontade de ser mãe, que nem me importava se pegasse uma gravidez de homem solteiro ou casado, eu não queria saber, queria saber que era meu filho, tanto que quando fiquei grávida tinha 15 anos e com 16 já era mãe, mas não quis casar de jeito nenhum. Depois juntei, veio a segunda gravidez e perdi o nenê com três meses, foi um desespero muito grande. Chorei, sofri e no resguardo já engravidei de novo. Aí veio a outra menina e assim fui tendo, mas mesmo assim não quis saber de laqueadura. Sempre falam para eu fazer, mas de coração não tenho vontade. Este dom lindo que Deus me deu! Tantas mulheres neste Brasil com vontade de ter filho e não podem e eu com este dom maravilhoso, nunca que vou me desfazer. Tenho quatro meninas e um menino, e agora estou esperando este menino.

Sou católica, só há duas igrejas onde moro na Vila Regina em Rio Tinto, no interior da Paraíba, a cento e poucos quilômetros de João Pessoa, cidade de 12 mil habitantes.

Com três meses e duas semanas de gestação, descobri que o meu bebê tinha um problema no coração. Foi uma notícia muito ruim. Minhas criancinhas são sadias, quando descobri esta gravidez sofri muito no início, foi uma surpresa muito grande, principalmente para o pai. Os médicos falaram que era uma doença muito grave e que o nenê não teria chance de sobreviver; falaram até que se eu já tinha cinco filhos porque iria correr atrás desse? Eles disseram que havia tratamento apenas em São Paulo. Então eu pensei "vou deixar meus filhos pequenininhos todos para trás e o que tiver que fazer para a vidinha deste bebê vou fazer".

Depois da gravidez deste bebê é que pude ter um pouco de liberdade, porque o meu marido não deixava andar na rua sozinha, realmente ele era muito ignorante, mas ele vivia andando por aí. Eu 
sofria muito de viver presa dentro de casa. No meu primeiro casamento, com o pai das meninas, eu tinha liberdade, ia para o rio, ia para praia, para a casa da minha mãe, em outra cidade. Tive quatro meninas do primeiro casamento e um menino, deste casamento, e o bebê que vai chegar. Mudou tudo agora! Quem era e quem é ele agora! Quando ficou sabendo do problema do bebê, se entregou à igreja, agora só vai da igreja para casa e da casa para a igreja. Há muitas barreiras que vou enfrentando com cuidado: sogra, contas e uma criança cheia de problemas de saúde. Abandonei a casa, hoje estou aqui em São Paulo e só volto quando meu filho estiver pronto para viajar.

Comecei meu pré-natal em Rio Tinto, mas a médica teve um problema na família e abandonou tudo, quem atendia era a enfermeira chefe. Passei três meses sem ser atendida, sofrendo muito. No início da gravidez tinha sangramento e não tinha ninguém por mim, só Deus. Sem companhia, saía sozinha de casa de madrugada para pegar um carro, sem ter ninguém, só Deus. De Rio Tinto, fui encaminhada para Mamanguabe, e o primeiro exame de ultrassom não acusou nada. Depois de 15 dias fui a João Pessoa, fiz outro ultrassom e descobri o probleminha dele, aí pronto, tudo mudou, porque a minha dedicação maior agora é para ele, e tem que ser assim, só pensar nele agora. Foi duro, muito duro, quando descobri, ah, meu pai do céu!

Eu não sabia se realmente viria para cá ou se me ficariam “cozinhando". Será verdade que vão me mandar para São Paulo? E aí o tempo foi passando e, quando tive certeza de que viria para cá, chorei muito de felicidade. Fiquei com saudades dos filhos e do marido, mas em primeiro lugar estava este bebê. Foi uma emoção muito grande, mas também foi desespero deixar o lugar onde moro para vir para um lugar desse, sem ter ninguém; não vejo a hora de voltar para minha cidade.

A primeira vez que fiquei sabendo do problema do bebê foi desespero, a segunda também. Na primeira foi falado que a doença 
que ele tinha era muito séria, e que poderia a qualquer momento morrer na minha barriga, um desespero muito grande. Na segunda, a médica falou para mim: "Mãe, você tem cinco filhos, vai abandonar os seus filhos por causa desse? Fica calminha, tenha o seu filho aqui na Maternidade Cândida Vargas, fica com ele um pouquinho, deixa ele no bercinho até a hora que Deus chamar!" Aí é que a minha ficha foi caindo aos poucos, fui tendo noção, fui tendo noção do tempo, saí da sala, peguei o carro para ir embora, entrei em pânico e cheguei em casa desesperada. Então decidi, não volto mais para essa médica não. Fui até a Secretaria de Saúde na cidade onde moro informar que não voltaria nessa médica. Todos ficaram contra porque ninguém pode tomar uma atitude dessa, querendo que eu tenha o bebê para morrer, para mim é a mesma coisa que interromper a gravidez, como se não tivesse como levar adiante esta gravidez.

Fui para João Pessoa e me colocaram para fazer o pré-natal na Maternidade Cândida Vargas. Fui à primeira consulta e a médica me explicou tudo. No outro dia fiz a ultrassonografia e ela falou que não tinha condições de fazer o pré-natal na minha cidade, que eu tinha que fazer em João Pessoa. Eu fiquei fazendo o pré-natal em João Pessoa, ficava melhor para mim, ela pegou meu telefone e ficou em contato comigo. Então, o médico entrou em contato comigo. Eles me chamaram para eu participar de uma reunião sobre os Pequenos Corações, atendimento com os cardiologistas de João Pessoa e a cardiologista do Recife dos Pequenos Corações da Paraíba. A cardiologista falou que não tinha condições de fazer o pré-natal onde moro, ela faz cardiofetal e acompanha pré-natal, então fiquei sendo acompanhada por ela.

Fiquei indo e vindo da minha cidade Rio Tinto até João Pessoa, vim três vezes no pré-natal com essa médica, quando ela viu meus exames de diabetes falou que estavam muito alterados. Então, precisei ser internada, passei 30 dias internada, sem nem ir para casa porque eles não me liberavam, tinham que cuidar de mim 
por causa do bebê. Quando passou esse tempo eles me liberaram dois dias para ir em casa me organizar e voltar já sabendo da viagem para São Paulo, não haviam marcado ainda, mas já estava perto.

Quando marquei a eco, estavam os cardiologistas de João Pessoa e a médica do Recife. Eles conversavam e tiravam as dúvidas, falavam bem baixinho para eu não ouvir, mas a cardiologista do Recife falava alto e eu entendia. Na última eco que fiz, ela falou: "Olhe, esse probleminha, ela não tem condições de ter o filho em João Pessoa, tem que ser no HCor em São Paulo, se essa criança nascer em João Pessoa, ela não resiste se for transferida para São Paulo, tem de nascer lá", e eu escutando tudo (referindo-se à teleconferência). A dúvida deles era se poderia ser parto normal, porque queriam que fosse cesariana e eu não, falei que queria parto normal. A médica do Recife me explicou que precisava ser cesariana porque ao nascer ele iria dar um "espirro muito grande de sangue" e o aparelho para puxar o sanguezinho dele precisava estar ali, porque uma hemorragia interna levaria o meu bebê. Então por causa disso tudo quando sentia uma dorzinha ficava "aperreada", não pela dor, mas sim pelo medo de perdê-lo. Não via a hora de vir para cá, pensava primeiramente em Deus e na equipe que iria tomar conta dele.

Eles me mandaram falar com a minha família sobre a ida para São Paulo. Desde o momento que falaram que o bebê só iria sobreviver em São Paulo e começaram a fazer contato com a equipe do HCor, eu queria qualquer brechinha, para ter essa oportunidade por causa do bebê. Então, chegou um dia que e a equipe me falou para me organizar até as 23 horas para eu vir para cá. A notícia realmente me pegou de surpresa. Entrei em desespero, chorei, mas chorei de alegria porque havia conseguido. Eles me falaram que o voo para São Paulo seria naquela noite, às 2 horas da madrugada, eu precisaria ir para o aeroporto às 23 horas. 
Respirei, peguei o celular e falei com meu marido e ele entendendo que eu iria só no outro dia. Falou que iria pegar um carro e levar o dinheiro para mim no dia seguinte e, eu falei: "Você não está entendendo, vou embora hoje mesmo, hoje à noite, pronto". Aí entrei em pânico, fiquei nervosa, sou uma "manheira" que só, para chorar sou uma manteiga, entrei em desespero, no banheiro, chorei, chorei, chorei. Meu marido falava: calma, não chore não, é por uma boa causa. Pedi para o meu marido me deixar chorar pelo menos uma vez, aí chorei tanto e ele mudo, eu de um lado e ele do outro. Perguntei "tu vens"? Ele respondeu que sim.

Quando chegou, trouxe só um filho, porque eu já tinha visto a pequenininha, então ele trouxe o pequenininho, porque não dava para trazer todo mundo. Meu marido me acompanhava nos exames de eco e ultrassonografias, ele ouvia a obstetra dizer "mãe, não chore, porque cada vez que você chora, está irritando o bebê", e realmente era, quando eu chorava em desespero assim que ele mexia muito e eu tinha muita, muita dor e depois passava. Mas sei que quando meu marido ficava só, ele também desabava, quando estava comigo ficava uma maravilha, eu via pelo jeito dele e o meu e aí a gente não chorava um na frente do outro. Mas houve um dia em que não aguentei, porque quando a gente vai e volta a saudade é maior da família, aí chorei mais em casa, chegava aquela horinha, pronto, entrava em desespero, porque tinha que deixar todos os meus filhos para trás. Caso fosse um ano ou dois, mas só vou voltar quando escutar da boca dos médicos "vá, você tem condições de ir". Ficava desesperada porque tinha de ir embora, pensava que não podia ficar com meu marido. Então os médicos falaram "não, mãe, você vai poder ficar com ele, só as crianças não podem ir, mas o pai tem de ir, tem de registrar". E aquilo foi me acalmando. Então ele chegou com meu cunhado e minha cunhada.

Foi assim, ele que nunca teve responsabilidade, vivia à toa, eu era pai e mãe, e de repente uma coisa dessas, ele fica em casa tomando conta das minhas filhas, tomando conta do menino, da 
casa. Este bebê deu uma virada em nossas vidas. Casamos, antes ele sempre dizia que não queria casar, agora está uma maravilha, saí do hospital e fomos para o cartório e casamos. Este menino nos deu muita coisa, virou a vida de cabeça para baixo, não tanto para mim, mas para o pai dele. O que era ele antes e o que é ele agora, mudou muito, foi uma experiência muito grande, está sendo. Eles querem que o pai chegue antes do parto para assistir e ir acompanhando o menino para ver que não é brincadeira, que é muito grave; no primeiro momento eles resolveram que a minha cunhada viria comigo.

O importante era vir, sabia que viria porque o importante era nascer por aqui. Falavam que a cidade de São Paulo era uma cidade muito grande, até hoje todo mundo fala assim. Eu realmente sou calada, sou calada que só. Perguntavam se havia alguma dúvida eu falava que não. Depois que cheguei aqui, conversei com poucas pessoas, o importante é que estou sabendo o que pode acontecer. Então, essa semana chorando de alegria e de tristeza, e agora está na vontade de Deus, eles dizem fé em Deus. Eu quero o melhor, Maria do Céu, voltar com o meu filho para Paraíba não vejo a hora.

Cheguei aqui sem noção de nada, o pessoal falava, "mãe, tu não imagina como é São Paulo, é muita gente, é muita gente que não é brincadeira, olhe você conseguiu uma vaga, gente com dinheiro quer uma vaga neste hospital e não tem, agarre, agarre essa oportunidade, agarre com todas as suas forças. Primeiramente, Deus vai Ihe soltar nas mãos dos melhores médicos para cuidar do seu bebezinho lá no HCor".

Eu achava mais força nos profissionais de saúde do que na minha família, uns da minha família mesmo diziam "se fosse mulher minha não ia", diziam "o Deus fiel unge aqui, tu vai ficar com a consciência pesada", e eu respondia que consciência pesada ficaria se tivesse o meu filho na Paraíba e visse o meu filho morrer à míngua, e saber que ele morreu e eu podia ter corrido atrás, Deus 
permitiu este caminho. Depois viram que realmente não iria voltar atrás, eu disse eu vou, eu vou!

Meu tio foi uma benção na minha vida, todo dia ali comigo, perguntando como eu estava. Este tio é por parte de pai, o meu pai faleceu e foi ele quem me criou, sempre me dando atenção, querendo saber como eu estava, acompanhava, perguntava do bebê, dos exames. Já da parte do pai do meu marido não posso dizer o mesmo, porque só tenho essa cunhada que veio comigo, mas sei lá!"

Data: 6/9/2013

Horário: $14 \mathrm{~h} 40$

"O meu bebê nasceu no HCor no dia 12 de dezembro de 2012, com peso de $3.475 \mathrm{~g}$ após seu nascimento ele foi encaminhado para a UTI neonatal.

No hospital, a equipe tomava conta do meu bebê enquanto ele estava na UTI; era muito difícil ver o sofrimento do nosso filho, mas a gente sabia que ele estava sendo bem cuidado. Quando recebeu alta da UTI e foi para o quarto, tive uma experiência muito linda de poder dar de mamar, pegar no colo, dar banho, até ele receber alta do hospital.

O nosso bebê recebeu alta, no dia 30 dezembro de 2012 foi outro desespero porque era só comigo, eu tinha que dar conta de cuidar. Fomos para casa de um conhecido do meu tio em Carapicuíba, e ele estava bem. Quando faltavam quatro dias para ele completar um mês notei que começou a mudar de cor, a ficar muito branquinho. O retorno no HCor seria no dia 8 de janeiro de 2013, mas ligaram e remarcaram primeiro para o dia 15 de janeiro, e depois mudaram de novo para o dia 22. Fazia 12 dias que a gente estava em Carapicuíba. E eu estava esperando este retorno no HCor para eu saber quando poderia voltar para Paraíba.

No dia 10 de janeiro ele passou mal e a gente correu para o Pronto Socorro de Carapicuíba; a médica falou que ele estava bem. 
Voltamos para casa, ele passou bem, estava fraquinho, mas mamou, mamava no peito. No dia seguinte ele acordou, dei banho e mamou normal, só que quando fui dar o "AS" e a polivitamina, os únicos remédios que ele tomava, ele vomitou. Tentei ligar para o HCor, mas não consegui, isso foi no sábado, ele dormiu muito, quando fui ver ele estava muito molinho, dei banho e arrumei, e ele de novo dormiu até as 17 horas, acordei para dar os remedinhos e ele vomitou. Ofereci o peito, ele mamou, mas não conseguiu engolir.

O dono da casa não estava e eu sozinha, quando chegou pedi para ir de novo ao Pronto Socorro, mas de repente ele começou a chorar sem parar, fiquei muito "aperreada", ele começou a ficar roxo, vi que não era normal e comecei a chorar. Fomos para o Pronto Socorro, ele olhando para mim do jeito que seria o "último suspiro", todo mundo ficou muito nervoso.

Quando chegamos no Pronto Socorro de Carapicuíba e a médica perguntou se ele havia engasgado, expliquei que ele havia operado o coração, então a enfermeira e a médica levaram para uma sala de atendimento e disseram que iam transferir para o Hospital Infantil de Carapicuíba.

No Hospital Infantil, o médico pediu os documentos dele e perguntou em qual hospital havia sido realizada a cirurgia do coração. Contei que havia sido no HCor, que ele recebeu alta e não tive como ficar em São Paulo, então vim para Carapicuíba onde tenho parentes. O médico ligou para o HCor, olharam a ficha dele e perguntaram se haviam dado remédio, eu disse que não, foi reanimado só com massagem, esperaram que ele ficasse melhor para transferi-lo para o HCor.

Teve duas paradas cardíacas no Pronto Socorro e três no Hospital Infantil, na última não resistiu. Os médicos me chamaram e explicaram que haviam feito de tudo para salvar meu filho, mas era muito grave o problema, poderia ser até que levasse adiante, mas provavelmente seria uma criança que a qualquer momento podia falecer. A médica chorava muito, eu num desespero. 
Parecia que o mundo havia desabado na minha cabeça. Quis ficar junto com ele, ele estava tão lindo, falei "lindo da mamãe", mamava no peito e estava tão gordinho, tão lindo. Meu marido estava na Paraíba, liguei para dar a notícia. Antes já havia ligado várias vezes avisando, mas ele já tinha escutado tanta coisa que achou que era alguma coisa da minha cabeça também. Então, foi uma correria do hospital para a delegacia, para o setor de óbito, para o cartório tirar o atestado de óbito dele, depois fomos para o IML, tudo tinha que pagar e quem estava me ajudando era o senhor da casa onde eu estava hospedada.

A funerária queria enterrar meu bebê em São Paulo, porque era muito gasto, e eu disse que NÃO, só voltaria para Paraíba com ele. Liguei muito para a assistente social do HCor, porque estava tudo complicado para a liberação, queriam dinheiro, falaram que não podiam se responsabilizar e havia quatro dias que ele estava no IML. O pessoal da ONG Pequenos Corações ligou para mim perguntando como eu estava, contei que estava arrasada, queria levar meu bebê comigo e a funerária não arcaria com as despesas e não sabia o que fazer, se em cinco dias não fosse ao IML retirar meu filho ele seria enterrado como indigente. Falei que se eu chegasse naquele IML e o meu filho tivesse sido enterrado como indigente botaria o IML abaixo, não ficaria nada em pé. O senhor da casa onde eu estava hospedada tentou ajudar, mas não conseguiu porque não tinha dinheiro, pois custava quase três mil. Então a moça da ONG Pequenos Corações ligou para outra funerária de Carapicuíba e com menos de cinco minutos me ligou e disse para não me preocupar que eu voltaria com meu filho para a Paraíba. Foi um alívio muito grande.

Então consegui levar meu filho para ser enterrado com dignidade perto da família. Quando cheguei à Paraíba com ele, não tinha noção de nada, só queria chegar em casa e ser acolhida pela minha família e pelo meu povo. Quando cheguei fomos direto para o cemitério, abri o caixão para a família ver o nenê, já estava dopada, 
cansada porque não dormi nada, mas a família estava ali e consegui levar meu filho para ser enterrado na Paraíba. Queria muito que ele tivesse vindo para cá vivo, mas foi a vontade de Deus e foi feita a Sua vontade, mas agradeço ter ficado esses trinta dias com meu filho, aproveitei muito, esse tempo valeu por uma eternidade.

Só posso dizer que eu, meu marido e minha família ficamos mais unidos. Meu marido já havia mudado para melhor, estava diferente, não tenho do que me queixar, valeu a pena. No começo chegaram a me aconselhar a não vir para São Paulo, e eu falei que ia sim, ia lutar se Deus quisesse levar meu menino levaria, mas antes eu ia lutar muito pelo meu filho. Passar esses 30 dias com ele vivo foi um presente, valeu a pena mesmo, faria tudo de novo. Quando cheguei, sofri muito, chorava pelos cantos quando via as coisinhas dele, as fotos, as roupinhas... Mas o tempo foi passando, foi diminuindo, porque passar não passa nunca, mas estou indo...

Mandei fazer uma mensagem para ele, um obituário que mandei colocar no seu túmulo (neste momento ela pede para uma das filhas ir buscar a mensagem que havia escrito para o filho). Muitos da família diziam que isso era besteira, para que fazer se ele já havia morrido, e eu explicava "olhe, o meu filho é meu filho e quero fazer esta homenagem, não me importo em gastar". Só tinha uma foto dele na carteira, a coisa mais lindinha, e foi com essa que eu fiz a homenagem. Essa criança na minha vida teve um propósito, tudo mudou, ele veio perfeito, mas com uma cardiopatia, sofri muito, e então ele foi embora, mas não tenho do que me queixar, foi muito bom ficar com ele, só conheci gente boa.

Da equipe do HCor não tenho nada para me queixar, meu marido tem a mesma opinião, ele passou quinze dias no HCor, o atendimento foi muito bom, a equipe é excelente!

Agora quero ler a mensagem que mandei fazer para ele: "Deus enganou-se ao enviar um dos seus anjos para terra, ao sentir sua falta veio buscá-lo, nosso conforto é saber que nosso anjo está com Ele"." 
Bebê da E2, em 14 de dezembro havia sido submetido ao tratamento híbrido com bandagem das artérias pulmonares direita e esquerda e colocação de stent em canal arterial, sem relato de qualquer intercorrência, ficou em ventilação espontânea, foi transferido para a enfermaria em 24 de dezembro por encontrar-se clinicamente estável. Recebeu alta no dia 30 de dezembro de 2012 em boas condições, em aleitamento materno e retorno ambulatorial agendado. Era considerado, pela equipe multidisciplinar, como um dos bebês com melhor evolução. 



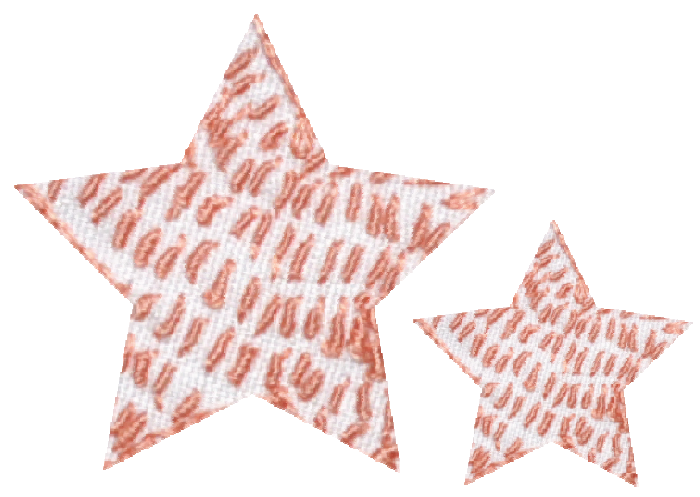

E3 tem 19 anos, ensino médio completo, é natural de São Paulo (SP), é católica e é solteira. Saindo da adolescência, até a pouco tempo desejava que sua mãe engravidasse e agora descobre-se grávida. 



\section{Data: 28/1/2013}

\section{Horário: 11 horas}

"Quando descobri que estava grávida, fiquei nervosa só pela gravidez em si, imagine quando fiquei sabendo da doença da nenê. Mas estou me acostumando. Tenho dois irmãos, uma irmã de 21 anos e um irmão de 15. Os meus pais são vivos, meu pai tem 53 anos e minha mãe 50. Nasci em São Paulo, moro em Carapicuíba e tenho o segundo grau completo. Trabalho como atendente de telemarketing há 11 meses em Barueri/SP, perto de casa, levo meia hora até o serviço, mas estou em licença. Sempre fui uma criança muito alegre e divertida, brincava muito; na adolescência não me imaginava grávida, eu e a minha irmã queríamos que a nossa mãe tivesse outro bebê para a gente cuidar, mas ela fez laqueadura. Então, quem ficou grávida fui eu; quando ela soube que eu estava grávida aceitou tranquilamente.

Fiz meu pré-natal em Carapicuíba. O primeiro ultrassom morfológico fiz pelo convênio no Hospital da Luz, na Vila Mariana, quando detectaram a cardiopatia na nenê. Fui encaminhada direto para o Hospital São Paulo, no Ibirapuera, perto da estação de metrô Santa Cruz, porque há estrutura para receber uma criança com este quadro. Fiz novamente o exame para ter certeza, outro exame de ecocardiograma, e confirmaram o diagnóstico. Comecei a ser atendida lá e fiquei sabendo da ONG Pequenos Corações por uma amiga da minha irmã. Então, a ONG me encaminhou para o HCor. Passei pelo Serviço Social do HCor, trouxe os documentos para avaliação social, fui bem atendida e me explicaram tudo, no mesmo dia me ligaram marcando consulta. Fui atendida pela cardiologista, pela enfermeira, pelo obstetra e agora é só esperar, já está tudo encaminhado, graças a Deus.

A nenê tem uma cardiopatia chamada SHCE, que foi confirmada quando consultei com a cardiologista do HCor no Instituto Dante Pazzanese, antes de vir para o HCor. A médica me 
explicou que seriam necessárias três cirurgias, teria que trazer a nenê ao médico de 15 em 15 dias, o procedimento seria longo, tudo deveria ser feito direitinho para não ter complicações. Ela me explicou tudo e não fiquei com nenhuma dúvida.

É muito bom ter essa oportunidade de chegar aqui no HCor, ter essa chance. Quando fui ao Hospital São Paulo para consultar o médico falou que seria muito bom ir para o HCor, porque no Hospital São Paulo a UTI está em reforma. Aqui no HCor há a psicóloga, que conversa comigo e fico mais calma, ela esclarece dúvidas, é muito bom mesmo.

A minha filha vai nascer no dia 13 de fevereiro, queria ter uma menina, mas se viesse menino, tudo bem. No primeiro ultrassom a nenê estava muito pequena, mas nos demais pude ver que era uma menina mesmo, então não tive mais dúvida, quando é o que a gente quer, melhor ainda.

Eu não procurava saber detalhes da cardiopatia, as pessoas falavam muito, e eu ficava muito preocupada, mas cada caso é um caso. No caso da minha nenê, o coração não se desenvolveu e quando nascer vai precisar fazer a cirurgia, porque ela iria tentar respirar e não iria conseguir. Fiquei sabendo o básico, não ficava correndo atrás, porque podia não ser verdade; como o médico disse pode ser o mesmo caso, mas cada criança é diferente, então eu não queria saber muita coisa. Só que os médicos já chegavam falando que havia o risco de ela não suportar a cirurgia, mas eu fico tranquila, confio em Deus. Quando cheguei ao HCor, a médica cardiologista ficou mais ou menos uma hora fazendo a ecofetal, explicou tudo, como seria daqui para frente e isso me deixou tranquila. Sei que há outras crianças com o mesmo caso aqui no hospital, mas não tive contato ainda com outras mães.

O tempo da minha casa até o hospital é de uma hora e meia. Ela vai nascer na quarta-feira de cinzas e vou internar na terça-feira de carnaval ou na quarta-feira às 5 horas da manhã, vai depender do resultado de uns exames para ver se estou com alguma infecção, 
se precisar tratar vai ser com antibiótico, se não o parto será na quarta-feira mesmo.

Acredito que no começo não vou ter medo de aprender a cuidar da nenê, vou contar com a minha tia e com a minha sogra. Meu namorado tem dois sobrinhos pequenos, então ele já sabe cuidar de criança. Eu é que faz tempo que não cuido de criança, mas estou aprendendo, está tudo pronto, o quarto dela está arrumado, agora é só esperar. No início, saber da cardiopatia foi difícil para mim e para o meu namorado, mas ele já se acostumou e está muito feliz por ser uma menina. Nós entendemos que o HCor é um lugar muito bom e vai ser feito o melhor para ela, então é só ficar tranquilo e esperar. Depois que a nenê nascer, eu e o meu namorado temos planos de morar juntos, mas temos que ir com calma, eu moro em Carapicuíba e ele em São Paulo.

Sou católica e acredito que a minha religião é a base de tudo. Lógico que não vou deixar de estar aqui no hospital, mas a religião ajuda muito, para mim pelo menos, me dá apoio. Agora procuro não pensar muito no assunto para não me abalar, não ficar nervosa, porque tudo passa para ela, acho que ela entende tudo. Converso sobre o assunto, mas não me abalo tanto como antes, no começo foi mais difícil, até para entender o que os médicos falavam, porque eles falam de um jeito... Mas agora me preparei psicologicamente. Estou me alimentando bem, acho até que demais, por estar em casa como mais.

Sabe, nunca havia escutado falar sobre cardiopatia congênita, foi a primeira vez; como eu não fazia ideia, fiquei muito abalada, depois fui entendendo; a minha vinda para o HCor aconteceu naturalmente, não foi difícil chegar até aqui, graças a Deus.

É a primeira neta da minha mãe e ela está feliz. Ela está preocupada e sempre me liga, apesar de a gente morar perto, uns 15 minutos uma casa da outra. Moro com uma amiga minha, a cunhada da minha irmã, mas minha mãe me dá toda a atenção todo dia. Ela mora com meus irmãos, a minha irmã está no último ano da 
faculdade de contabilidade e o meu irmão está no segundo ano do ensino médio. Para o meu pai foi mais difícil aceitar a minha gravidez, no começo aceitou, depois foi mais difícil, mas acredito que quando ela nascer tudo muda.

O meu namorado vai assistir ao parto e ficar como meu acompanhante nos cinco dias de licença-paternidade, e eu ficarei como acompanhante dela; mas no dia do nascimento vem todo mundo, minha mãe, meu pai, meus irmãos e também a família dele e depois vamos nos revezando. O meu namorado também trabalha com telemarketing; a mãe dele é para mim outra mãe, graças a Deus, somos muito amigas. A minha filha será o terceiro neto dela, mas é a primeira menina, ela queria muito uma menina, está boba."

\section{Data: $12 / 3 / 2013$}

\section{Horário: 15 horas}

"No dia do nascimento, fiquei nervosa quando cheguei ao HCor, entretanto todos foram muito prestativos e não me deixaram ter medo. Tinha medo da anestesia e nem doeu. Quando ela nasceu, foi direto para a UTI. Foi todo um tratamento para mim no parto, acho que foi muito importante, o fisioterapeuta, a enfermeira, o médico, tudo certo. Remédio que não acabava mais para eu não sentir dor, tudo muito bom. À noite fui conhecer a minha filha, não via a hora, o parto foi de manhã e só fui vê-la à noite por causa da cesariana. Ela nasceu na quarta-feira e na manhã seguinte já fez a cirurgia.

Ela fez uma cirurgia chamada processo híbrido com os médicos do HCor, um faz a cirurgia e outro coloca o stent no coração. A cirurgia levou umas três horas, foi tudo bem. Ela ficou na UTI de quinta-feira até domingo, na segunda-feira iria para o quarto, mas como pegou uma infecção, recebeu alta somente na terça-feira. Ela ficou bem, mas na sexta-feira começou a ficar "roxinha", a saturação dela caiu para 20 , ficou ruim de novo e voltou para a UTI, 
o pulmão dela estava fechando. Eu pensava que era só o coração, mas depois da cirurgia no coração aparecem outros problemas que eu nem imaginava.

O pulmão começou a fechar, mas com a fisioterapia começou a abrir no dia 22 de fevereiro, e ela ficou melhor. Ela estava no CPAP direto, então intercalavam, colocavam no cateter; se ela ficasse direto no cateter voltava para o quarto. Fez um monte de exame.

Nessa semana infeccionou o local da cirurgia, o osso, foi preciso abrir, limpar, cicatrizar e fechar de novo, e tomar antiinflamatório. Então, fez cateterismo para ver se melhora e hoje vai fazer broncoscopia. Vamos ver, se der tudo certo no exame hoje ela começa a ser extubada, quem sabe vai para o quarto; ela está bem melhor do que quando voltou para a UTI. Todos muito atentos, de parabéns, não tem nem como explicar, não tem nem do que reclamar.

Em Carapicuiba senti mais dor por causa da cesariana, porque não fiz resguardo, estava todo o dia no ônibus, tendo de vir para o HCor. Não ia deixar de vê-la, todo dia de ônibus, e depois todo o dia em pé, sentava pouco; de noite eu chorava de dor. Agora estou bem melhor, a cirurgia cicatrizou e está tudo bem, apesar de tudo isso. O obstetra viu que está tudo bem cicatrizado.

Há dias em que fico no hotel da ONG Pequenos Corações, que é perto do HCor. Posso ficar bastante tempo com a nenê, só não posso ficar na troca dos plantões. Normalmente chego às 9 horas e vou embora por volta das 19 horas, só saio das $12 \mathrm{~h} 30$ às 14 horas por causa da visita médica e da troca de plantão. Há o horário de visita, mas não há problema em ficar direto, prefiro ficar perto. Quero ir logo para casa, apesar de ser bom para ela estar no HCor, eu queria pegá-la no colo, amamentar, cuidar dela e aqui eu não posso...

Estava estimulando a amamentação, só que começou a secar e a ter bem pouquinho leite, porque de noite eu não fico aqui e não 
tiro tanto como deveria, então aos pouquinhos vai secando. Se ela pegar para incentivar acho que ainda consigo amamentar, mas há o banco de leite, e tenho tirado o leite.

Eu e o meu namorado estamos bem, ele está vendo a nossa casa, vamos morar juntos. Ele está trabalhando, trabalha de manhã e vem à tarde para cá, chega por volta das 17 horas, fica com ela. No começo foi mais difícil, ele voltou a trabalhar, ainda não se acostumou com tudo que está acontecendo, mas se adaptou com a rotina de trabalhar e ter de vir para cá, porque não tem como se acostumar com um filho doente. Quando ela faz cirurgia, ele não vai trabalhar, pega atestado. A situação foi melhor do que eu esperava, porque todo mundo apoiou muito, desde o serviço da faxineira até o do médico, até o chefe da UTI, não tenho nada a reclamar de ninguém, todo mundo sempre disposto, o que eu queria eles davam um jeito. Foi muito mais do que eu esperava, até fisioterapeuta no quarto, muito bom mesmo, não tenho como agradecer.

Converso bastante com as mães. Cada uma tem uma trajetória diferente, pode ser a mesma doença, mas depois as complicações são diferentes, cada criança é uma, parece que é a mesma coisa, mas são reações diferentes.

Agora ela fez o cateterismo, a saturação dela melhorou bastante. Hoje vai fazer exame e se der tudo certo vão extubar. Se ela conseguir ficar no cateter vai para o quarto na próxima semana, se não der certom, vão ver o que fazer. Se não conseguirem tirá-la de jeito nenhum do CPAP ou do cateter, ela vai fazer a metade da segunda cirurgia. Fazem a segunda cirurgia de quatro para seis meses. Se não for possível em função do peso, pois ela está com três quilos e não aguentaria fazer toda a cirurgia, só daqui a um mês e meio ou dois. Então vão fazer a metade da cirurgia; os médicos não explicaram como vai ser, só vão explicar se ela precisar fazer, só disseram que existe a possibilidade de fazer metade da cirurgia agora e a outra metade de quatro para seis meses. Isso pode acontecer somente depois de testar tudo, é a última tentativa. Como 
ela está melhorando bastante, acredito que não vai ser preciso e logo ela vai para casa. A expectativa é muito grande, uma vontade de pegá-la, sair correndo e levá-la para casa.

O apoio da família é grande, todos preocupados, vêm ao hospital para vê-la; sempre que preciso de algo, sou ajudada em tudo. Estão todos torcendo para ela ir para casa logo.

A alimentação dela é por sonda. Nos três primeiros dias ela chegou a pegar mamadeira na UTI, mas começou a ficar cansada, então colocaram a sonda e agora está na sonda direto. No quarto, ela começou a pegar o peito, mas voltou para a UTI e está na sonda com $40 \mathrm{ml}$, só quando vai fazer exame fica em jejum, mas mantém os $40 \mathrm{ml}$. No início não sabia que iria ser por sonda, pensei que ia poder amamentar, quando explicaram entendi, embora quisesse muito dar-Ihe o peito, ou a mamadeira, mas o importante é ela receber leite de algum jeito.

Está sendo assim, já estou melhor, tive muitas surpresas, pois acreditava que era só fazer a cirurgia e ir para casa, não sabia de toda essa recuperação, todo este procedimento, mas está muito bom. Ela já abre os olhos, entende tudo, eu a deito ali e ela entende, mas dá dó, o olho dela enche de lágrima, parece que quer chorar, mas é muito bom ficar ao lado dela, nem tem como explicar.

A psicóloga me ajuda bastante. Antes era outra, mas como no dia do parto era carnaval e ela estava viajando fiquei com esta psicóloga, que é muito legal, ela é uma amiga, conversamos, ela me explica, eu entendo. É muito bom esse procedimento, pensei que somente a criança recebia o tratamento, mas nós também somos tratados.

Acho que não tenho nada de negativo para falar do serviço, não tenho mesmo, agora meu desejo é levá-la para casa." 
Bebê da E3 foi a óbito no dia 3 de julho de 2013. Houve muitas complicações nos procedimentos realizados. Seus pais estiveram sempre presentes, acompanhando o tratamento e lutando por sua recuperação. 


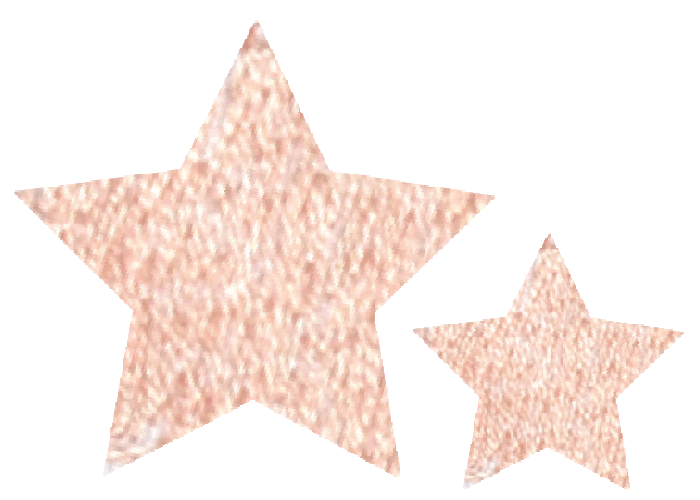

E4 tem 34 anos, ensino superior incompleto, mora na cidade de Sinope (MT), é casada e é evangélica. É mãe de um menino de cinco anos, planejou sua segunda gravidez com o intuito de dar um irmão ao seu $1^{\circ}$ filho e queria muito que fosse uma menina. 



\section{Data: 20/2/2013}

\section{Horário: 15 horas}

"Tenho minha família toda perto, graças a Deus! Sou casada há seis anos. Meu marido tem 34 anos, quando o conheci já havia sido casado quatro vezes e não teve nenhum filho, pensei que ele não podia ter filhos e não me cuidei, então com dois meses de casada estava grávida. Foi uma surpresa, eu tinha 18 para 19 anos e um filho, ainda, não fazia parte de meus planos.

Meu filho tem cinco anos, não foi uma gravidez planejada, mas hoje é a minha vida. Ele é totalmente saudável, muito carinhoso, está o tempo inteiro beijando, abraçando, falando eu te amo. A parte mais difícil de estar aqui é não escutar "boa noite mãe, eu te amo", todo o tempo perto de meu filho é só carinho, se estou lavando roupa ele me faz parar para abraçar, beijar, é muito carinhoso. O lado bom é que ele entende o que estou fazendo aqui (referindo se ao fato de estar fazendo o tratamento em São Paulo).

Agora estou no nono mês da minha segunda gestação, que foi planejada. Quando tive o meu primeiro filho, foi parto normal e senti muita dor, não queria mais de jeito nenhum outro filho. Mas o meu filho com três para quatro anos começou a pedir uma irmã, queria uma irmãzinha, e foi quando me apaixonei pela ideia. Então, tirei o DIU, não posso tomar anticoncepcional, e logo engravidei desta menina, mas descobri que ela tem um probleminha. Acho que vai ser pequeno perto do que Deus vai fazer na minha vida com a vinda dela. Estou muito feliz com a gestação, vou ficar mais feliz ainda quando estiver com ela nos braços, estou contente, apesar dos problemas.

A gestação do meu menino foi tranquila. Passei 14 horas de sofrimento no parto, perdi a força e quebrou a clavícula dele na hora de tirar, mas em 15 dias estava bem. Mamou até um ano, mas complementava com mamadeira. Meu filho é muito tranquilo, carinhoso, não dá trabalho, não tenho preocupação. Planejei a 
minha menina em função dele, porque ele queria muito. Quando ele falava de ter irmã, eu brincava "mas você vai ajudar a mamãe a limpar o cocô dela?" Ele falava "não vou não!" Uma vez meu marido estava viajando e o meu filho sentiu muito. Estávamos deitados na cama e ele falou "mãe, faz uma irmãzinha para mim, eu jogo a fralda dela no lixo" (risos). Quando meu marido voltou conversamos e, por ele, desde os dois anos do nosso filho, já teríamos outro nenê, mas havia o trauma do parto. Resolvi superar isso e tentar.

Nos 11 meses em que fiquei tentando engravidar fiz cinco testes de gravidez, atrasava dois dias e fazia o teste. Um dia na casa da minha mãe, eu estava gripada e vomitando muito, o meu irmão comentou "mãe, a minha irmã está grávida". Então chegou um amigo professor, que é vereador e a esposa demorou 11 anos para engravidar, tudo sobre gravidez ele sabia, e passou a mão nas minhas costas e falou "você está grávida, pode fazer o exame", disse que a textura da pele da mulher na gravidez fica diferente. Na manhã seguinte fiz o teste, quando comecei a urinar, foi automático aparecer a segunda faixa que indica gravidez. Dois dias depois fui à minha ginecologista e ela pediu o exame de sangue que confirmou.

A obstetra é a mesma que tive o meu filho, há seis anos consulto com ela. Comecei a fazer o pré-natal, com cinco meses fiz o ultrassom morfológico e descobri que era uma menina. A médica falou que havia uma alteração no coração, mas fiquei tão feliz por ser uma menina que não prestei atenção. Na realidade somente entendi quando a médica falou que talvez o parto não pudesse ser lá. Na minha família não há cardíacos, então desconhecemos totalmente esse assunto.

O susto veio quando passei no cardiologista fetal e com o ecocardiograma fetal foi diagnosticada a cardiopatia SHCE. Ele explicou a gravidade da doença e do tratamento: um lado do coração da menina não havia se desenvolvido. Em Mato Grosso não há tratamento, o parto seria em outro hospital, o risco não era baixo, seriam três cirurgias, a primeira mais simples e as outras duas mais 
complicadas. Primeiro tentou o atendimento onde tínhamos parentes, porque sabia que seria demorado, mas somente temos parente em São José do Rio Preto e lá não há tratamento. Então me encaminhou para o HCor em São Paulo e explicou o básico para eu vir sabendo o que me esperava.

No início não tínhamos noção de nada, não conhecíamos a cidade, tão grande, e ficávamos assustados com algumas coisas que acontecem aqui e que passam na televisão. Não tínhamos nenhuma referência, mas a dona de um supermercado onde moro falou que eu poderia ficar na casa da filha dela, que também tinha um bebê com problema, nasceu de seis meses e ficou 78 dias na UTI. Isso foi um alívio porque o custo de vida é muito alto. Estou na casa dela há 20 dias, quis ir para a ACTC, mas não deixaram, graças a Deus são pessoas boas. Nos primeiros dias me deram todo o apoio, ainda mais quando deu problema com a filantropia, porque fui encaminhada pelo plano de saúde, que não cobre o tratamento. Cheguei a São Paulo em um dia e no outro dia tive consulta com a médica do HCor no Dante Pazzanese. Ela fez o ecocardiograma fetal e confirmou o diagnóstico, explicou novamente a gravidade da doença e me encaminhou para o HCor.

Cheguei aqui e fiquei encantada, pois me acolheram muito bem. Tenho um plano de saúde que aqui em São Paulo não é bom, sei que este plano é só por Deus. Não vou dizer que tenho uma religião porque estaria mentindo, frequento a igreja evangélica, não sou muito de igreja católica, mas não sou assídua. Meu pai é pastor da Igreja Tradicional da Graça, então eu vou. Mas a fé é muita. Quando o plano não quis bancar o tratamento, a assistente social de Sinope falou que eu teria de voltar para vir encaminhada de lá, só que já estava com 33 semanas e nenhum médico queria me liberar para viajar e se responsabilizar. Fiquei tão desesperada que cheguei a falar que Deus havia virado as costas para mim. Depois me arrependi e pedi que me mostrasse um caminho. No outro dia tudo se resolveu. 
É obvio que os conveniados são bem acolhidos, só que aqui não estou pagando nada, estou pelo Estado, e fui tão bem acolhida. As pessoas me receberam com tanto carinho, conversaram e me explicaram como será, e agora não estou tão ansiosa e nervosa como quando cheguei. Achei maravilhoso, porque geralmente as pessoas tratam bem quando pagamos, tenho consciência disso, e aqui é como se eu estivesse pagando muito porque sou muito bem tratada. Todos são muito bons, não posso falar de ninguém, todos me receberam com a mesma conversa, sorrindo, brincando, o tempo inteiro. Ainda não conheço outras mães além da mãe que está me hospedando em sua casa. O bebê dela tem o mesmo problema que a minha, ele tem um ano e três meses e já fez duas cirurgias. Quando cheguei ela falou "tomara que você vá para o HCor, lá somos bem atendidas, todo mundo recebe bem, é muito bom o tratamento do Hospital". Hoje passei na consulta do obstetra do HCor, um amor de pessoa, me deixou à vontade na consulta, explicou tudo e informou que, como o HCor não é uma maternidade, se eu entrar em trabalho de parto antes da data marcada devo ir para o Hospital Cachoeirinha, que é o mais perto de onde estou.

Na nossa família é tudo muito novo, não há cardiopatas na família, então todo mundo ficou sem saber o que ia acontecer. Queria muito ter trazido a minha mãe, mas ela é muito emotiva, e também está cuidando do meu filho. Ele sabe do problema da irmã, no dia do diagnóstico do cardiologista sobre a SHCE, quando vi a minha mãe a primeira reação foi "desmontar" e ele presenciou, só que ficou quietinho. Quando entramos em casa ele falou "mãe, vamos conversar, o que o médico falou que fez você chorar?" Expliquei para ele "a mamãe foi ver a sua irmã, ela está "dodói", a mamãe não vai poder ficar aqui com você, quando a mamãe ganhar vai para outra cidade, você vai ficar com a vovó". Ele falou "tudo bem, mãe, você vai, mas vai voltar. Quando você voltar já vou estar grande?" Ele é muito compreensivo, uma criança muito legal, meu amigo, sou uma mãe coruja. Falo com ele todos os dias e a 
preocupação dele é se já estou no hospital, porque sabe que quando eu vier para o hospital ele virá. Meu marido é mecânico da Volkswagen, vai ficar aqui comigo, os patrões são ótimos, ele foi liberado 15 dias. Virão os meus dois homens (risos). A minha sensação é a de que a vinda deles levará embora metade dos meus problemas, vou ficar mais tranquila.

O meu parto foi marcado para o dia 4 de março, estou nervosa, agora faltam 15 dias, tomara que passem rápido porque nos meus primeiros dias aqui o tempo não passava nunca. Já fazem 20 dias que cheguei, parece que fazem meses... Hoje penso que se aconteceu comigo é porque tenho de passar por isso, independente do que acontecer é algo que vai me engrandecer lá na frente, ou Deus não teria permitido. No início pensava "meu Deus, se o pecado foi meu porque a minha filha vai pagar", dizem que os filhos sofrem por causa dos pais e eu pensava dessa forma. Depois fui pensando, tanta mulher grávida que entrega o filho para os outros, porque isso aconteceu com a minha filha? Sou uma mãe ruim? Será que não iria cuidar bem? Eu pensava assim, hoje não, hoje penso que, se é para eu passar, vou passar independente do que aconteça."

\section{Data: $8 / 4 / 2013$}

\section{Horário: 13 horas}

"O meu parto ocorreu no HCor, no dia 4 de março, conforme o planejado. O enfermeiro que foi me buscar é uma pessoa excelente, ficou o tempo inteiro conversando comigo para me distrair. Fui tão bem atendida na hora do parto, a psicóloga ao lado, os médicos e o anestesista o tempo inteiro dizendo que estava tudo bem, pois de uma forma ou de outra é muito aflitivo, pensava que havia o risco de perdê-la ali, na hora em que ela se desligasse de mim. O meu marido assistiu ao parto e me deixou mais tranquila, ficou o tempo todo segurando a minha mão, conversando comigo, pois é meio 
traumático porque nunca se sabe sobre o parto, minha mãe sempre diz "quando a gente engravida é um pé no chão e o outro na cova".

O obstetra, que pessoa maravilhosa, até brincou depois da cirurgia "nossa, eu sou muito bom mesmo", porque foi uma coisa bem feita. Ele e a outra médica conversavam comigo enquanto me cortavam para me manter calma. $O$ anestesista também foi muito gentil, o tempo inteiro ao meu lado, os enfermeiros, sem comentários, todos maravilhosos. Depois, durante os três dias de internação fui muito bem tratada, o modo como as meninas cuidaram de mim foi excelente, fisioterapia excelente, me ajudaram bastante, tanto que nem parecia que havia feito cirurgia, já estava caminhando pelo hospital. Mas tive medo, tem a alegria de ver ali que chegou a hora do nascimento, mas o medo toma conta, por saber que o bebê vai direto para a UTI e que pode haver alguma intercorrência no tempo de espera para cirurgia.

Ela nasceu às 9 h30 e fui conhecê-la por volta das 21 horas, porque precisava esperar a anestesia passar e ter uma pessoa me acompanhando. Na hora que nasceu me deixaram dar um cheirinho, mas olhar mesmo, tocar, só à noite depois que passou a anestesia e que conseguia ficar em pé. É complicado explicar os sentimentos, a alegria de ver que está ali, que chegou, mas o medo em pensar no dia seguinte quando faria a cirurgia, então tocava o bebê com medo de ser a última vez. É alegria e tristeza ao mesmo tempo.

Tive muito medo de perdê-la no parto, mas no segundo dia foi muito traumático - como as mães dizem uma para a outra "não desejo isso nem para um cachorro" - ter de levar a filha até uma sala de cirurgia e esperar quase três horas, por mais que se tenha informação o tempo inteiro. Difícil escutar que a cirurgia deu certo, mas houve intercorrências e foi preciso fazer transfusão de sangue, pois a pressão dela baixou muito. Houve essas dificuldades, a despedida, eu me despedi antes da nenê entrar na sala de cirurgia, a angústia dessas três horas e depois esperar mais duas horas para 
vê-la, e então encontrá-la intubada, sedada, toda molinha, dá uma sensação ruim, mas está aí, está lutando!

Ela está com 34 dias e são 34 dias de UTI e três de expectativa de ir para o quarto, mas é só falar que vai para o quarto que ela faz uma "arte", nada que me desespere e me faça pensar que vou perder a minha filha. São coisas pequenas que a seguram na UTI, a traqueia inchou então foi intubada, fizeram a dilatação, mas há o tempo de cicatrização, então começou tudo de novo. Prefiro que seja assim a ir para o quarto ou para casa e depois ter de voltar, posso ficar bastante tempo com ela fazendo "arte", mas quero levála bem, sem preocupação.

O meu filho veio junto com o pai quando ela nasceu, ficaram dez dias, me ajudaram muito. Quando foram embora, o meu leite até secou, por mais que estivesse com a minha sogra, me senti só. Agora à distância conversamos todos os dias, mas não é a mesma coisa. E ainda complicou, porque meu filho teve dengue, eu com ela aqui e o meu marido com ele lá internado, então minha cabeça não estava nada bem. Quando soube da dengue chorei muito, pensava "o que eu fiz para estar passando por tudo isso?" Foi uma semana muito conturbada, porque coisa ruim vem tudo junto, a minha filha que não ia para o quarto, a minha irmã operando, meu filho e a minha mãe com dengue, o que é isso?

Eu fazia uma refeição por dia, só o almoço que inchava na barriga, conversava com meu marido e ele dizia "amor, você tem que ser forte, estou cuidando dele aqui internado, ele está bem, não teve todos os sintomas, está fazendo o terror aqui no hospital". Meu filho ficou internado cinco dias. Por mais que soubesse que ele estava bem, eu não estava lá vendo, e se eu fosse quem ficaria no hospital com ela? Pensei até em desistir de tão traumático, não dá para ser forte sempre. A minha sogra estava comigo, há três dias foi embora. Amo minha sogra, mas ela estava mais desesperada que eu. Às vezes tinha vontade de chorar e me segurava para não afetála. Ela sempre se mostrou uma mulher muito forte, então quando 
veio pensei que não teria pessoa melhor para estar comigo, mas no final eu tive de ajudá-la. Complicado! Ela sempre queria saber "por que a bebê está assim? Os médicos estão escondendo alguma coisa da gente? Ela não está bem?" Eu dizia “a senhora não está me ajudando".

Recebo o boletim médico todos os dias, até comentei com a minha mãe esses dias ao telefone que vou sair daqui formada em cardiopatia (risos). Quanto a isso não posso reclamar, sempre falam de uma forma que eu entenda o que está acontecendo com a minha filha e me deram liberdade para perguntar o que não entendo. $A$ médica cardiologista é esplêndida, todos são muito bons, mas ela tem um jeito maravilhoso de explicar, é muito séria, mas não deixa nenhuma dúvida. Os outros cardiologistas também são pessoas que não escondem, explicam o que acontece e qual atitude vão tomar, e assim consigo entender o que acontece com ela. Nunca me deixaram com dúvidas, até porque pergunto muito, não fico guardando para mim alguma coisa que vi e não achei certo, eles estão sempre à disposição para me responder e explicar o que está acontecendo. A psicóloga também está sempre por lá, quando passa e não estou deixa recado que voltará no dia seguinte, sempre me ajudando.

Ainda estou na casa dos meus amigos no bairro do Limão, saio todos os dias cedo e passo o dia inteiro no HCor, vou embora antes de escurecer porque tenho medo de andar aqui. No início me assustei muito, porque sou de uma cidade pequena onde o trânsito é calmo e as pessoas conversam. Aqui não, ninguém conversa com ninguém. É tudo muito louco, o trânsito, gente o tempo inteiro, não se vê essa cidade num final de semana com poucas pessoas, ônibus lotado, metrô lotado, muito diferente de onde moro. Então os primeiros dias me impactaram, tinha medo de sair, de andar, até quando vinha às 6 horas da manhã (em meia hora estava aqui), vinha andando segurando a bolsa, a mão até doía de tanto que segurava por medo, porque a gente mora fora e ouve muito coisa de 
São Paulo. Hoje ando mais tranquila, ainda cuido da bolsa, mas não vejo a hora de ir embora. Como a minha sogra foi embora, vou tentar vir para a ONG Pequenos Corações, perto do hospital, porque é um gasto muito alto vir todos os dias de ônibus e metrô. Também vou ficar mais tempo com a minha filha por não precisar sair mais cedo.

Na ONG fica tudo mais fácil e também estão outras mães, vou conviver mais com elas. Não posso dizer que sou privilegiada, mas sei de mães em situação bem mais difícil e são essas mães que vêm passar a mão na cabeça e falar que vai dar tudo certo. Muitos membros do hospital não gostam das conversas entre as mães, não concordam muito com essa troca de experiência, porque temem que algumas mães possam ficar deprimidas. Mas isso é bom, umas ajudam as outras ao contar a experiência dos filhos. Por exemplo, eu tinha medo do tal do cateterismo, mas todas as mães falaram que foi a melhor coisa que fizeram quando o filho não estava bem. Outra vez estava com medo de a minha filha fazer a broncoscopia, porque é muito invasiva, mas as mães diziam que era bom para identificar e retirar algo obstruindo. Então é bom conversar com as mães. Esses dias conheci uma mãe que o bebê já foi para a terceira cirurgia e em 15 dias saiu como se nada houvesse acontecido. Outro dia veio uma senhora só para mostrar a filha de um ano e seis meses, ela falou "acredita em Deus porque a minha filha não tinha expectativa de vida", teve de colocar um marca-passo, hoje é uma menina esperta, brincalhona, linda, a gente vibra com isso.

A minha filha está na UTI, apesar de o coração estar ótimo. Toda vez que ela saía do CPAP (pressão positiva contínua nas vias aéreas) e ia para o oxigênio por uma semana ficava muito cansada, e não conseguiam entender a causa do cansaço, pois o pulmão estava limpo, faziam todos os tipos de exame e estava tudo bem. Com a broncoscopia conseguiram ver que o tubo machucou a traqueia, inchou e cicatrizou inchada, estava aberta, mas apertada. Fizeram a dilatação e a saturação dela está bem, entraram com corticóide, ela vai ficar intubada até a cicatrização, depois volta todo 
o processo de novo, CPAP, oxigênio, pensar em mandar para o quarto. Assim fico mais aliviada, porque até então não sabíamos o que estava acontecendo. Agora é só tratar e se Deus quiser vamos embora, porque o coração que é o motivo de estarmos aqui está bom.

Agora não posso pegá-la, e é tão bom ela no meu colo; pegueia com 13 dias a primeira vez. Quando podia pegar o braço dava até cãibra e ficava firme para não soltar, e quando soltava ela fazia escândalo. Ela está mais esperta, antes teve um coágulo na cabeça que a deixou aérea, não tinha percepção das coisas, conversava com ela e demorava a me olhar, sempre muito durinha. O coágulo diminuiu, tem dois milímetros, então ela está percebendo melhor o ambiente, converso e ela fica me olhando, vou sentar e ela fica me procurando, também o cheiro ela já sente, a voz já reconhece.

Estou sendo bem tratada aqui, as enfermeiras são excelentes, não têm aquele padrão frio. Elas têm uma preocupação com a mãe também, procuram nos tranquilizar. Por exemplo, quando minha filha intubou de novo, recebi muito apoio, explicaram que o tubo é a melhor opção para abrir o pulmão e deixá-la mais forte. A fisioterapeuta explicou que é comum intubar e extubar. São pessoas que estão sempre me ajudando, me tranquilizando. Às vezes vejo algo diferente na máquina e elas me explicam, gostam de conversar com a mãe. Não há uma enfermeira que possa falar que não gostei. Se reclamo de alguma coisa, logo agradeço, é uma situação complicada e o tratamento que a minha filha está recebendo é muito bom. As mães estão sempre observando e se há alguma alteração as enfermeiras correm para verificar, há um interesse de todas de realmente cuidar e de fazer o melhor." 
Bebê da E4 foi à óbito com 88 dias de vida, no dia 31 de maio de 2013, devido às inúmeras complicações decorrentes dos procedimentos a que foi submetida. Conversei com sua mãe por telefone que relatou estar aliviada, pois não aguentava mais vê-la sofrer. 



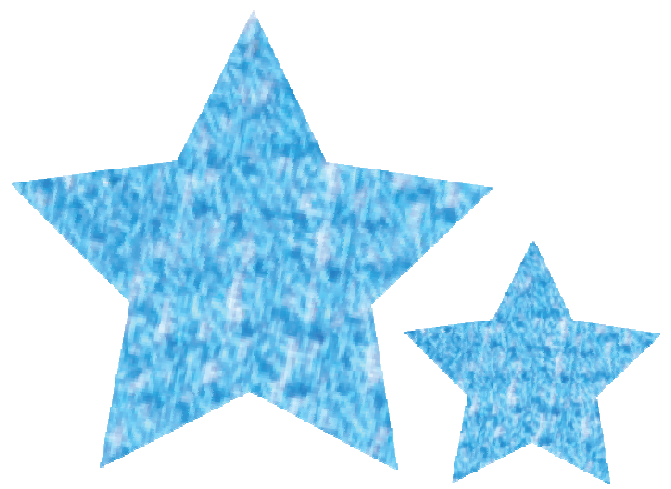

E5 tem 19 anos, ensino fundamental incompleto, é natural de São Gonçalo (MG), é evangélica e é casada. Descobre a atual gravidez quando seu primeiro filho tem apenas três meses de vida. 



\section{Data: $4 / 2 / 2013$}

\section{Horário: 16 horas}

"Nasci em uma cidade pequena de Minas Gerais, somos quatro irmãs e um irmão, tive uma infância boa, muitos amigos, adorava brincar de Barbie e me lembro dos meus aniversários que a minha mãe organizava. Na adolescência gostava muito de sair com as amigas. Assim minha infância e adolescência foram muito tranquilas. Convivi pouco com meu pai, ele se separou da minha mãe e hoje mora aqui em São Paulo com outra família, e não tive mais contato. A minha mãe casou-se de novo e meu padrasto foi um pai para mim, ele é um amor de pessoa. Passou um tempo e me mudei para Pouso Alegre, uma cidade maior, também, em Minas, foi onde conheci o meu marido.

Estudei até a quinta série, depois desanimei, mas tenho vontade de voltar a estudar, vou pegar firme no estudo, quero um trabalho melhor. Trabalhava com a minha mãe em uma fábrica de pizza e pastel quando descobri que estava grávida do meu primeiro filho, e parei de trabalhar. Não era casada e quando a gravidez se confirmou conversei com a minha mãe e com meu namorado e decidimos morar juntos. Agora estamos arrumando a casa e falei para ele que quero casar.

Quando descobri que estava grávida do meu primeiro filho, pulei de alegria, ganhei tanta coisa do meu marido, é o primeiro neto dos meus sogros e o terceiro da minha mãe. Quando ele nasceu, foi maravilhoso! Fiz o pré-natal em Pouso Alegre, tinha consulta com a nutricionista e com a psicóloga, quando fiz o primeiro ultrassom, adorei que era um menino, meu marido queria uma menina, mas quando soube que era menino adorou, só tinha coisa de menino. Foi muito bom quando vi o rostinho dele, vi que era menino, vi o coraçãozinho bater. Ele nasceu em uma sexta-feira 13 em janeiro de 2012, foi cesariana porque ele estava sentado. Ele nasceu e nem vi o rostinho dele, levaram ele para limpar e só fui ver no quarto, dei 
mama para ele, as enfermeiras deram banho nele no quarto mesmo, foi quando minha mãe e meu marido chegaram. Meu marido foi quem ficou mais emocionado, encheu o olho de água, a minha cunhada também estava lá.

Depois de três meses do nascimento do meu filho engravidei novamente, foi no resguardo, quando meu marido ficou sabendo que estava grávida não queria aceitar. Por isso com esse filho passei mais necessidade, quando fui fazer o ultrassom foi a minha mãe que pagou, porque do primeiro filho o meu marido pagava tudo, comprava presente, porque era o primeiro filho. Deste filho ele não queria saber, se fosse uma menina talvez ele quisesse, quando falei que sentia que era um menino, ele já ficou meio "enfezado", não quis pagar o ultrassom, não queria aceitar esta gravidez de jeito nenhum.

Além disso, o resultado da ultrassonografia deu que o neném tinha um probleminha no coração. O médico não me explicou direito o que era, ou pode ser que tenha explicado e eu é que não entendi muito bem, lembro que fiquei muito nervosa e preocupada, não dei muito ouvido na hora para o que ele falou, eu sai sem entender qual era o problema, qual era o caso, se era isso mesmo. No outro dia a minha mãe foi lá e o médico explicou tudo para ela: "o nenê está com esse probleminha, vai ter que ir para São Paulo ou para Campinas para tratar e fazer um ultrassom do coraçãozinho para ver se é isso mesmo". Então a minha mãe pegou o ultrassom e a gente viu tudo certinho e foi assim que aconteceu.

O médico de Pouso Alegre me encaminhou para a cardiologista do HCor aqui em São Paulo, primeiro, passei no Dante Pazzanese e depois fui encaminhada para o HCor. Aqui a cardiologista do HCor explicou melhor, falou como era o nome da doença, acho que é Síndrome de Hipoplasia do Coração Esquerdo, sinceramente não entendo muito destas coisas, aí a minha sogra até veio comigo. A cardiologista do HCor falou: "vou ser sincera com você, o que o nenê tem é grave. No segundo dia depois que ele nascer no HCor, vai ser feita a primeira cirurgia". Já fiquei com 
medo, operar um bebê novinho, pequenininho, dependendo do jeito que nasce aquela coisinha delicada, fiquei com medo, o maior medo meu é o nenê não aguentar... (choro, muito choro).

Visitei o HCor e a moça (referindo-se a colaboradora da hospitalidade) mostrou onde eu e ele vamos ficar, como que vai ser. Conheci outra mãe que também tem um caso como o meu, esqueci o nome dela, estava lá e também vi o menininho dela, fez a cirurgia, nossa, vi como ele se recuperou bem, fiquei até mais aliviada porque se o dela pôde se recuperar porque o meu não. Ela falou que é a segunda cirurgia dele em seis meses, acho que ela está ainda aqui no HCor agora para esperar.

Estou na ACTC aqui em São Paulo, um lugar que dá apoio às mães que vêm de fora com problemas de saúde, cada pessoa tem um problema de saúde, chega um atrás do outro, chega pessoas que a gente nunca viu na vida. Tem uma menina que também esta grávida e o bebê também tem problema do coração, ela é lá de perto da Bahia, boazinha, a gente fica sempre conversando. Estou estranhando os horários das refeições, não sou muito chegada a frutas, sou mais de legumes, verdura gosto de comer. Gosto de comer toda hora, na minha casa estava sempre comendo, aqui não, tem horário e o jantar é muito cedo, seis horas da tarde.

Não conhecia São Paulo, é a primeira vez que vim para cá, nossa, é grandão, nunca imaginei que iria ver assim de perto, gostei, só via pela TV. Aqui na ACTC têm pessoas com sotaques diferentes, cada uma veio de uma cidade, falam engraçado, gosto de falar com elas, fico rindo dos sotaques.

E todas nós sabemos que agora está na mão de Deus, é o que a minha mãe conversa sempre comigo "entrega nas mãos de Deus", porque a gente não pode fazer nada. Sou evangélica, a única solução é orar, pedir para Deus que ele tenha cura. Que venha saudável e forte." 


\section{Data: $13 / 3 / 2013$}

\section{Horário: 16 horas}

"Depois da nossa última entrevista voltei para a ACTC, onde sempre havia alguma atividade para fazer e é onde fico com outras mães que têm os filhos com outros problemas de cardiopatia congênita. Lá é legal, a gente tem amizade, sempre saindo e chegando gente. Quando voltei várias mães já tinham ido embora, depois de eu ter feito muitas amizades.

A minha sogra ficou comigo quando a minha mãe foi embora. $A$ minha mãe queria ver o bebê nascer, queria participar do parto, mas não deu, porque a data marcada no HCor era no dia 13 de fevereiro, quarta-feira de cinzas. O pré-natal estava marcado para o dia 11 de fevereiro, e eu estava meio em dúvida, sabia que não ia chegar até a data marcada. Quando a minha mãe tinha acabado de ir embora no sábado, no domingo já comecei a sentir dor. Para mim não era a dor de parto porque nunca senti dor do meu primeiro menino. Então senti umas contrações, achei que era cólica, mas foi aumentando, aumentando... Quando falei para a minha sogra que estava sentido dor, ela ficou preocupada, falou para as meninas da ACTC, elas ligaram para o táxi, então fui para o Hospital das Clínicas, onde ganhei o bebê.

Chegando lá fui sentindo mais dor ainda. Meu esposo ligando, chorando, preocupado, falando que não era para os médicos fazerem o parto normal. A minha sogra não pôde ficar comigo, no Hospital das Clínicas não deixam acompanhante. Podia ficar até na hora que vai para a sala do parto, mas na ACTC só pode entrar até às dez horas da noite, então ela não pôde ficar comigo.

Como as médicas falaram, se eu entrasse em trabalho de parto antes da data marcada no HCor era para ir para o Hospital das Clínicas. Era final de semana de carnaval, foi de domingo para segunda. Falei para as médicas que o nenê tinha um problema no coração e que não podia ser parto normal, que era difícil o caso 
dele. Falaram que não tinha problema, que eu que tinha que fazer força. Como ele não queria descer de jeito nenhum acabou fazendo cesariana. Mas foi difícil, a médica que chegou falou que não tinha problema nenhum, que era ele que tinha probleminha, que não ia prejudicar ele, podia ser parto normal, iriam anestesiar. Que dependendo da anestesia, eu que ia ficar fazendo força. Falei: "é, nunca vi isso, eu fazer força e o nenê não. De qualquer jeito o nenê tem que fazer força para sair, né?" Ele só nasceu de cesariana porque trocaram de médico. Mas depois que nasceu, achei estranho, ele chorou baixinho, não teve força, não saia som nenhum quando chorou. Ele não chora alto. Depois desci para o quarto e fiquei três dias nesse quarto, sem vê-lo. Ele nasceu na segunda-feira e foi transferido para o HCor, só na quarta-feira fui vê-lo já na UTI.

Foi ruim, porque queria ter ganhado ele aqui, mas ele não esperou. Estava tudo combinado, na quarta-feira era para vir cedo, já tinha vindo conhecer o hospital, até a psicóloga iria me acompanhar, ela falou que ficou triste. Achei que lá ela poderia ir, meu irmão ia ligar para ela para ver se iria ficar comigo, mas falei "deixa quieto", apesar de que seria bom ter uma companhia ali comigo, ficar um pouco despreocupada. Estava com medo de ele nascer, de acontecer alguma coisa, por isso queria ganhar ele aqui, estava tudo certo, planejado para quando nascesse, sabia onde ele iria ficar, o quarto que eu iria ficar... Quando recebi alta, meu marido foi me buscar e me trouxe direto para cá para vê-lo, foi emocionante! Quando o vi, chorei e me veio na cabeça que devia estar com dor, porque estava com dreno, intubado, com medicamentos, curativos, chorei ali na hora... Mas as enfermeiras chegaram para me acalmar, disseram que ele não estava sentindo dor, que estava tudo bem com ele e fiquei bem mais calma, tranquila sabendo que ele estava bem cuidado, estava bem melhor.

Na segunda-feira o meu marido precisou vir para assinar os exames e autorizar os procedimentos que nem sei o que era. Quando me reencontrei com meu marido foi bom, porque ele, 
tadinho, desesperado de um lado, eu chorando de dor do outro... Ele chorando de medo de poder acontecer alguma coisa ainda mais com o bebê, a mesma coisa eu, estava demais preocupada. Foi uma luta porque não sabia se ficava preocupada comigo ali na hora do parto ou ficava preocupada com ele, chorando de medo, mas deu tudo certo, graças a Deus, agora o bebê está aí firme e forte.

Após essa cirurgia ele ficou na UTI sete dias, depois subiu para o quarto, teve uma recaída e voltou para UTI de novo. Foi aí que passei a ter medo de voltar para o quarto com ele, falei para a minha mãe e para a minha sogra que não ia voltar de medo de acontecer alguma coisa de novo. Os médicos falaram que, dessa vez que ele voltou, estava tudo certo, ele passou a noite bem, mas na manhã seguinte não estava indo ar para o pulmão e teve que voltar para a UTI. Também houve uns problemas a mais que não entendi. Ele ficou acho que uma semana e meia lá e falei para a minha mãe que não ia subir com ele com medo de acontecer alguma coisa de novo, aí a minha sogra veio. Ela ficou uma semana com ele e gostou de mais de ficar aqui.

Voltei para a minha cidade, Pouso Alegre, fiquei lá um tempo com meu menino, meu outro filho, que estava com anemia, anemia não, pneumonia. Ele tem um ano e sete meses. Agora está bem, passei um tempo com ele e matei a saudade. Mas estando aqui sente saudade de lá, estando lá sente saudade daqui... Sentia falta demais do bebê, aquele medo de ter deixado ele sozinho, preocupada... A minha mãe acabou vindo, porque eu ainda estava com medo e fiquei mais uma semana com meu menino.

Então meu bebê teve pneumonia, pneumonia não, anemia, teve que receber sangue pela veia. Depois estava meio ruinzinho e voltou para a UTI de novo. Os médicos falaram que estava cicatrizando por dentro e apertando o pulmão, não estava mandando ar, achavam que era por isso que ele estava tendo essa recaída. Aí a gente voltou rapidamente para cá para ver o que tinha acontecido, o médico explicou que tinha que fazer um exame que era 
cateterismo, explicou como era, cortar a veia dele pela perna para chegar até o problema do coração. Depois falou que era isso mesmo, que estava apertando e tendo dificuldade para passar o sangue para o corpo, aí voltou para a UTI de novo. Então os médicos falaram que está bem melhor, não deu mais nenhuma recaída, e fiquei bem melhor vendo isso. A gente que é mãe sente quando a criança está bem, e eu vi que ele estava bem melhor e conversei com a minha mãe, com a minha sogra, com o meu marido, dessa vez quis subir para o quarto com ele, me enchi de coragem porque vi que estava bem melhor, agora eu vou.

Saia da ACTC às oito horas da manhã, o nosso motorista trazia a gente em uma kombi. Quando chegava aqui tinha o boletim das $10 h 30$ e depois das 17h30. No horário de visita podem entrar duas pessoas, eu via os médicos que falavam que estava tudo bem com ele, graças a Deus, então não tinha aquele momento de tristeza. Tive esse momento de tristeza na reunião dos pais onde você faz perguntas e eles respondem. Teve uma reunião que conversei com a cardiologista do HCor, ela me incentivou a participar da reunião e tirar dúvidas: "mesmo que você ache que é uma pergunta boba é melhor perguntar do que guardar para você, pode perguntar". Fui numa quarta-feira que o meu esposo estava aqui e perguntei se o coração dele tinha cura e ela falou que não, só não chorei porque senti muita vergonha, mas bateu uma tristeza, fiquei angustiada. Falaram que não tinha cura, mas tinha tratamento para mantê-lo vivo, então fiquei mais tranquila. Graças a Deus, pelo menos ele está firme e forte e os boletins médicos sempre falam que está tudo bem com os procedimentos e exames que ele faz.

Quando ele estava na UTI, às vezes eu passeava nas horas que não podia ficar com ele e estava achando até gostoso São Paulo. Cheguei a pensar "e se eu morasse aqui", mas depois pensei melhor e vi que o melhor era ficar perto da minha familia, dos meus parentes. Ainda mais em hospital, não é bom ficar, é ruim, ninguém deseja ficar em hospital. Sempre pensava em vir conhecer São 
Paulo, mas nunca pensei que seria por conta de hospital, nunca desejei, mas aconteceu. Mas está bom porque estou sendo muito bem atendida, aqui está acontecendo tudo do jeito que vocês falaram mesmo.

Eu falo direto com o meu menino que está lá em Pouso Alegre ao telefone, apesar de ele não falar eu escuto os gritinhos e os berros dele, ele responde "mã" toda hora, aí mato a saudade.

O meu bebê vai fazer outra cirurgia daqui a cinco ou seis meses e outra com três anos, então penso que está na mão de Deus."

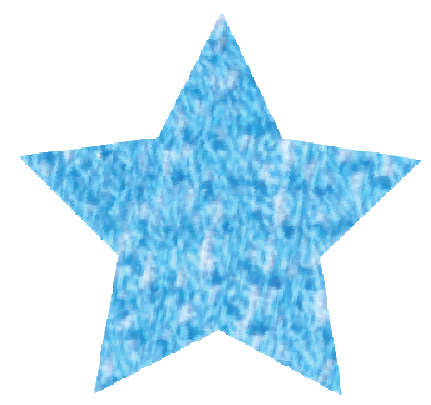

Bebê da E5 recebeu alta no dia 26 de agosto de 2013, com seis meses e 14 dias de vida, em boas condições clínicas, após ter vencido todas as complicações advindas do tratamento proposto. A princípio, com agendamento semanal ao ambulatório do HCor. 


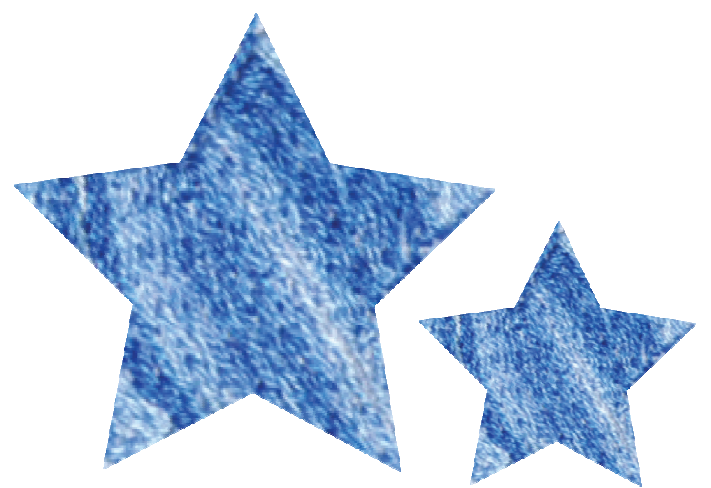

E6 tem 24 anos, ensino médio incompleto, é natural de São Paulo $(\mathrm{SP})$, reside na Baixada Santista, é casada e é espírita. Tinha planejado a gravidez para daqui a um ano, mas ela e seu marido ficaram felizes quando souberam que teriam um menino. 



\section{Data: $24 / 4 / 2013$}

Horário: 12 horas

"Ter sido encaminhada para cá foi um "achado" (referindo-se ao HCor). Sou da Baixada Santista e fazia meu acompanhamento pré-natal lá. Com 21 semanas de gestação, fiz um ultrassom morfológico e a minha médica me deu um diagnóstico não muito agradável, ela me deu um laudo de que ele poderia ter alguma doença cardíaca muito grave. Então, sugeriu que fosse feito um ecocardiograma, fiquei muito tensa, porque ela deixou nas entrelinhas, e fiquei na expectativa do que poderia ser. A minha médica teve que esperar o ecocardiograma ser feito com 30 semanas, entre 26 e 30 semanas (nesse período estava com 21 semanas, passou muito tempo até as 30 semanas), para que não houvesse nenhuma margem de erro. Então, fiz com 30 semanas e foi constatada uma SHCE.

Fui encaminhada para um hospital de referência na Baixada Santista, onde havia UTI Neonatal, mas que não havia cardiopediatria, só que isso não foi informado na primeira consulta para que eu pudesse tomar alguma providência, não foi informado que eu não teria nenhum amparo lá. Falaram que eu teria toda a assistência, que poderia ficar tranquila, mas que não podia entrar em trabalho de parto. Apesar de os protocolos não terem nenhuma confirmação de que os bebês com Hipoplasias não podem nascer de parto normal, é conveniente que nasçam de cesariana, para não forçar o bebê, mas que o parto seria lá, eles têm UTI e o meu bebê teria todos os cuidados. Disso você entende o quê? Que eu podia ficar tranquila, apesar do risco e da gravidade do assunto, o bebê teria os primeiros cuidados.

Estava com 35 semanas e passei no pronto-socorro por acaso. Encontrei o médico chefe do hospital que perguntou o que eu estava fazendo ali com um laudo daqueles, que tinha que correr para São Paulo. Do dia para noite ele marcou retorno para mim com a equipe, 
chamou o chefe da obstetrícia do hospital, que foi bem categórico e falou com todas as letras: "Seu bebê não tem metade do coração, seu bebê vai morrer. Agradeça a Deus que já tem uma filha, porque este bebê vai morrer. Tenho 15 anos de cardiopatia, tenho 50 casos, com o seu 51, só um sobreviveu. Antes de 2005 eles morriam na primeira cirurgia, ou dois ou três dias após, depois de 2005 eles passavam a morrer na segunda cirurgia ou, então, no meio do caminho entre o primeiro e o sexto mês de vida. Está bem?" Simples assim!

Fizeram um exame que tira sangue do cordão umbilical e um ecocardiograma. Por coincidência, a médica que me deu o primeiro diagnóstico, que fez o ultrassom com 21 semanas, é residente no hospital, estava de plantão naquele dia e estava na sala com a equipe. Ela lembrou do meu caso, estava com o ultrassom na mão, e chamou o chefe da obstetrícia (isso quem me disse foi o médico chefe do hospital, que estava bem próximo a mim, a sala era pequena e tinha bastante estagiários e residentes). Ela disse ao chefe da obstetrícia: "Fui eu quem deu este diagnóstico com 21 semanas, apesar de ser uma Hipoplasia, não é tudo isso". Eu estava prestando atenção em tudo o que estavam falando. O médico chefe do hospital estava falando, mas comecei a focar no que ela dizia, que "não era tudo isso", então o chefe da obstetrícia pediu para ela se calar e que depois explicaria o que estava acontecendo. Foi tudo bem claro, meu marido estava na sala comigo, ele viu, tinha uma estagiária que ficou indignada, estava na cara dela que estava vendo aquilo. Como é que você fala para uma pessoa "seu bebê vai morrer, agradeça a Deus que já tem uma filha", isso não existe...

Foi uma sequência de erros, porque com 21 semanas já poderiam ter começado a tomar alguma providência. Eu fazia o prénatal na UBS, fui transferida para o Ambulatório Médico de Especialidades - AME, que quando viram o diagnóstico me transferiram para o hospital de referência. Em todos os momentos escutei que a Hipoplasia é das doenças cardíacas, a mais grave, de 
quatro em cada 10.000 bebês nascem com essa doença. Então, como é que eles não têm uma referência, não sabem o que fazer. Há meninas da Paraíba que tiveram mais amparo do que eu, que estou em Santos ao lado de São Paulo.

O hospital para onde fui encaminhada é uma referência, é um hospital universitário, até então a UTI Neonatal deles é a melhor, são especializados em alto risco, isso é fato! Disseram isso para mim e começaram a "passar a bola". Estava com 35 semanas e o obstetra falou que faria o favor de me dar uma carta de referência para eu conseguir um hospital em São Paulo. Mas, se eu quisesse tentar alguma coisa, que pegasse meu carro e viesse com meu marido procurar um hospital, porque não é obrigação do Estado dar uma referência, ele não tinha obrigação, ele iria lembrar o nome da médica que conhecia para ver se conseguia fazer uma carta para mim e que eu voltasse na semana seguinte para fazer acompanhamento do bebê. Também falou para tirar o sangue do bebê, me explicou como funcionava: "Fica pronto em quatro semanas, provavelmente o bebê já vai ter nascido, mas pelo menos já está feito, porque depois vai precisar mesmo" - como se tivesse plena certeza que o meu bebê iria a óbito, em todos os momentos disse isso.

Fui para casa e não tive reação alguma, achei aquilo um absurdo, mas não tive reação de chorar, de xingar, de brigar... Achei ele um lixo, porque tudo o que ele me disse foi extremamente absurdo. A minha mente começou a trabalhar como faria mais para frente, porque eu vou processar! Vou processar ele, vou processar a equipe dele, vou processar o AME, vou processar a Prefeitura. Porque lá atrás fui com um diagnóstico e foram passando um para o outro. Meu médico foi bem claro e marcou a minha consulta para 20 dias depois com o obstetra chefe do postinho. O obstetra veio só para me ver e falar que não precisava ter esperado 20 dias, pois, se era questão de alto risco, todo mundo sabe que o postinho não faz pré-natal de alto risco e que tem que encaminhar para o ambulatório 
de especialidades, o AME. Meu médico já estava errado ali. Esperei mais 15 dias para conseguir uma consulta no AME, o AME tinha que esperar diante dos protocolos 30 semanas para não dar margem de erro, mas minha médica encerrou meu pré-natal.

O médico chefe do hospital disse que o pré-natal do bebê é uma coisa e o da mãe é outra. Em caso de alto risco passa-se a fazer o acompanhamento do bebê e não da mãe, apesar de que foi tudo a mesma coisa, continuei fazendo meu pré-natal, medindo a pressão, peso, isso e aquilo foi feito lá. Ele disse que o AME não deveria ter me mandado embora, apenas ter dado o encaminhamento para o local, e que ele não tinha obrigação nenhuma de me dar referência, não tinha obrigação de nada. Não sou da cidade de São Paulo, não estou inscrita em nenhum programa da cidade. Se o meu bebê resolver nascer hoje vou para o HC (Hospital das Clínicas), vou ficar na fila, não têm prontuário, então é de praxe que tentem fazer parto normal, se eu não tiver uma assistência, tem toda aquela situação que pode ser que aconteça é o normal, procedimento do hospital, tem todo um risco aí que corri por falta de estrutura deles, e então cheguei ao HCor, porque saí de lá e fiquei pensando o que fazer.

Como é que vou para São Paulo, se não estou inscrita em nenhum programa de lá, teria que ir só na hora do parto. Pensei em mandar um e-mail para me informar. Então, fiz uma seleção na internet e mandei um e-mail para todos os hospitais: Hospital das Clínicas, Alberto Einstein, HCor, não lembro o que escrevi, lembro que perguntei o que deveria fazer. No outro dia, a equipe do HCor entrou em contato, ligou e perguntou se tinha os exames e poderia escaneá-los, pois tinha falado com o cardiologista e estava aguardando os exames para ver uma melhor data para minha consulta, porque já estava com 36 para 37 semanas de gestação e queriam agir bem rápido. Enviei todos os exames no mesmo dia (isso foi na quinta-feira), ela ligou e marcou uma consulta para segunda-feira e pediu uma documentação. 
O atendimento foi excelente, explicaram como funciona a Filantropia e pediram meus exames. O médico chefe do hospital da Baixada Santista acrescentou no exame que o bebê, além da Hipoplasia, tinha um defeito no septo e foi bem claro, fez cariotipagem porque provavelmente o bebê teria outra anomalia. Tenho o laudo feito por ele dizendo isso. Porém, no HCor deu que o meu bebê só tem SHCE. Apesar da gravidade do assunto não é para tudo isso, porque as veias dele têm boas passagens, então não dá para afirmar, mas provavelmente o bebê tem tudo para se recuperar bem, tem bom peso, bom tamanho, meu bebê está com $49 \mathrm{~cm}$ e $2,900 \mathrm{~kg}$, ele é um menino. Na semana passada estava com esse peso, então por isso a obstetra achou interessante esperar até segunda-feira, dia 29 de abril, porque ele ainda vai ganhar mais peso e crescer um pouquinho, e estar com todos os tecidos realmente bem maduros, e assim terá tudo para ter uma recuperação melhor. Também não tem defeito nenhum no septo, a cardiologista teve algumas dificuldades para encontrar algumas veias no exame da ecofetal, mas é normal neste caso e está tudo dentro dos conformes, tudo para que o bebê tenha uma boa recuperação.

A minha saúde é boa. Porém, nesta última semana tive um pico de pressão, acredito que tenha sido por ansiedade, pois minha pressão sempre foi estável - $10 \times 8$ ou $11 \times 9$, nunca mais do que isso. Durante toda a gestação não tive nenhum tipo de problema com a pressão, mas nesta última semana fiquei muito tensa, ansiosa, porque o parto está marcado. A médica sugeriu que viesse ficar uma semana antes aqui na ACTC, porque lá não teria estrutura para ter o meu bebê. Mas tenho uma filhinha e não queria deixá-la. Tem toda uma situação por trás disso, não é só vir para cá. Meu marido tem que trabalhar para poder me manter aqui, e quem poderia me ajudar é a minha sogra, mas esta semana está com alguns problemas e vai ter que se ausentar, então está preocupada. Os planos eram outros, a gente tinha se programado para o bebê 
nascer mais para frente e iria nascer na Baixada, apesar de todo mundo estar ciente da gravidade do assunto eles tinham programado meu parto para maio.

Mas nem a transferência para São Paulo eles garantiram se o bebê nascesse na Baixada Santista, era um risco muito grande que estaria correndo. Particularmente me sentiria muito mais à vontade se tivesse ficado em casa com minha filha e família. Está tudo muito conturbado, minha filha vai para casa da avó pela manhã, para a casa da tia, todo mundo ajuda, todo mundo se divide, mas não é a rotina dela, ela é pequenininha, ela está passando de um lado para outro. Para ela é legal, não entende o que está acontecendo, mas para mim não é legal, foge completamente dos meus padrões.

Nasci em São Paulo, minha infância foi muito tranquila, estudei aqui até a oitava série, até meu pai falecer. Minha mãe faleceu eu era muito nova, tive um irmão gerente de um banco que foi assassinado e meu pai faleceu um ano depois. Eu tinha de 13 para 14 anos, fui morar na Baixada Santista com a minha tia, mas foi tudo muito tranquilo. Na realidade essa tia não tem vínculo sanguíneo, mas a gente sempre conviveu muito, ela sempre quis que eu fosse morar com ela, achava que São Paulo não era lugar de criar uma criança, e que seu quisesse vir para cá era só depois para estudar, porque criança aqui vive em prédio trancada, isso não é infância. Então, tive uma infância legal, uma adolescência legal, com boa estrutura. O tempo foi passando e conheci meu marido em Santos. Logo que nos conhecemos eu tive a minha filha, meses depois estava grávida, nós já estávamos planejando, mas pegou de surpresa, foi um momento legal. A minha menina está com dois anos, nasceu em São Vicente, é um amor de criança, muito inteligente e esperta, ela nasceu de parto normal, nasceu um pouco antes, porque tive um acidente de carro e a minha bolsa estourou, mas foi tranquilo, minha gestação e parto foram tranquilos.

A minha filha foi muito desejada porque meu marido é um pouco mais velho que eu, tem 35 anos, e queria muito ter filhos e 
nunca tinha conseguido. Ela foi muito esperada e foi um momento bem legal. Tínhamos planejado outra gestação para daqui um ano, mas nesse meio tempo teve a troca do anticoncepcional, estava parando a amamentação dela e engravidei. Logo ficamos sabendo que era um menino, ficamos muito felizes, pois agora vamos ter um casalzinho. A minha filha não entendeu no começo, mudou o comportamento quando viu que chegavam coisas de bebezinho iguais as dela. A criança muda de comportamento, foi ficando mais ciumenta, regredindo um pouco, não usava mais fralda então para chamar atenção começou a fazer xixi na roupa, nada muito absurdo, uma mudança de comportamento normal.

$\mathrm{O}$ meu marido sempre me acompanhou nas consultas. $\mathrm{Na}$ época trabalhava como mestre de obras, mas mesmo que se atrasasse, chegava a tempo para me acompanhar, estava presente em todos os momentos. Ele tenta não mostrar nenhum tipo de reação, porque me desestruturei um pouco, esperava uma coisa e foi outra. Sou espírita, então foi mais fácil levar a situação, mas a gente nunca quer passar por nada disso. Não podia desmoronar porque tenho uma filha pequenininha, mas me desestruturei quando o médico disse que não podia ter o meu bebê lá, não sabia para onde correr. O médico ia me prestar um favor, mas até agora não me deu referência de nada, isso realmente me incomodou bastante.

Quando cheguei ao HCor o primeiro atendimento foi da assistente social. É um contato muito próximo, diferente, normalmente a gente tem algum contato com os médicos muito técnico e aqui em todos os momentos a equipe da assistência social, a equipe da enfermagem, tudo é um contato muito próximo, então foi mais fácil. As pessoas contam histórias, contam situações, algumas são muito agradáveis, mas sempre tive muito os pés no chão. Tudo caminha para que o meu bebê tenha uma boa recuperação, mas aqui tive uma noção da realidade, que realmente é grave, mas vou estar bem acolhida. A equipe recebeu a gente muito bem, toda a equipe da obstetra teve um contato muito próximo. Tive uma 
consulta com ela, mas foi muito próximo, ela não foi técnica em momento algum, me explicou como as coisas iriam funcionar de uma forma bem objetiva e bem próxima, falou comigo de uma forma bem normal, não usou termos técnicos em momento algum. Isso me deixou bem confortável, foi muito legal, justamente por isso até que não queria correr o risco de entrar em trabalho de parto e ganhar o meu bebê em outro lugar.

A chegada de um bebê é um presente seja ela como for. Muitas mulheres tentam, tentam e não conseguem. Cada um tem uma missão, cada um tem uma carga. Mas com a chegada do bebê não tenho opinião formada sobre o meu lado espírita, não consegui me centrar para ver o que sinto em relação a isso. Hoje a minha cabeça está muito confusa, penso várias coisas, mas não é uma coisa que me assusta. Daqui para frente vou ter uma luta constante, viver em médicos, mas não acredito nisso, particularmente não acredito nisso.

Cresci aprendendo Espiritismo de Kardec, depois virei espírita de Candomblé, é onde me sinto bem. Se tiver que passar, tenho plena consciência que a gente vai passar por alguns momentos difíceis, mas acredito que as coisas vão se estabilizar bem rápido, esta é a única certeza que tenho, não é um desejo, como se quisesse me apegar a uma ilusão, não, é o que realmente sinto."

\section{Data: $10 / 9 / 2013$}

\section{Horário: 9 horas}

"O nascimento do meu pequeno, tão esperado por todos, graças a Deus, foi bem tranquilo. Ele nasceu como previsto no dia 29 de abril de 2013, em boas condições, apesar da gravidade da cardiopatia, não precisou ser intubado, clinicamente falando foi tudo mais tranquilo, até mesmo os médicos se "espantaram". Seus três primeiros dias de UTI foram ótimos, fomos muito bem atendidos, meu contato com ele nesse primeiro momento não foi bom porque 
eu estava recém-operada, para vê-lo precisava do acompanhamento de uma enfermeira, o que dificultava um pouco algumas vezes pela demora. Tive alta médica no dia $1^{\circ}$ de maio, fui aconselhada pela equipe médica a ir para minha casa antes da cirurgia do bebê, que estava sem data marcada, com o coração na mão assim fiz, ele estava cercado de cuidados e eu já estava me preparando para os próximos dias que seriam intensos e constantes dentro da UTI. Fui ver minha filha, já estava há sete dias longe dela, nunca tínhamos ficado tanto tempo longe uma da outra, mas era por um motivo justo.

Na quinta feira à noite, bem tarde, fui avisada que a cirurgia do meu bebê seria na sexta-feira, dia 3, pela manhã. Achei um pouco falho isso, pois o contato com a equipe foi muito próximo, todos sabiam que eu estava na Baixada Santista e já voltaria na sextafeira, mas como a operação seria muito cedo qualquer imprevisto poderia atrapalhar, porque a enfermeira disse que se eu não chegasse a tempo seria remarcada. Ficamos todos apreensivos, mas graças a Deus correu tudo bem e antes do horário eu já estava no HCor. Meu marido não pode ir porque estava trabalhando, minha sogra estava cumprindo com suas obrigações espirituais, então eu estava "sozinha", com medo, mas muito confiante, tinha certeza que daria tudo certo como deu, meu anjinho desceu por volta das 7 h40 para o centro cirúrgico, estava lindo...

O médico que o operou veio falar comigo antes e depois da cirurgia. O tempo estimado de operação era de até oito horas, mas com quatro horas e meia, aproximadamente, já havia saído do centro cirúrgico. Muito atencioso, o médico me disse que meu filho havia sido um guerreiro, que tudo correu muito bem, foi uma cirurgia enorme, acabou bem antes do tempo previsto, mas isso não diminuía os riscos, pelo contrário, ele sairia da sala com o esterno aberto, segundo ele o procedimento mais adequado nesses casos.

A cada boletim médico meu coração saltava pela boca, mas me mantive muito calma, estava falando com meu marido e minha família o tempo todo pelo telefone, apesar da proximidade de todos, 
os conhecimentos mais detalhados da cardiopatia quem teve fui eu, então nem tudo que os médicos diziam eles compreendiam, o que fazia com que tudo parecesse mais assustador do que era, foi feita uma corrente de orações muito grande pelo meu pequeno. Por volta das $12 h 30$ os procedimentos haviam acabado e ele foi preparado para voltar para a UTI. Estava ansiosa para revê-lo, os segundos pareciam eternos, só pude entrar às $14 \mathrm{~h} 30$, quando me deparei com ele todo esbranquiçado, intubado, cheio de aparelhos invasivos pelo corpo, desmoronei, me acabei em lágrimas, achei que tudo estava perdido, meu coração sangrou. Não esperava ver meu filho daquele jeito, criei uma fantasia na minha cabeça, o cirurgião foi tão confiante e positivo, ele ficou tão bem antes da cirurgia, coisa de mãe, me deu choque, uma sensação terrível e a partir daquele momento meu alarme de mãe começou a falar mais alto.

Fiquei algumas horas com ele, recebi o boletim médico e fui para a ACTC, onde fiquei hospedada o tempo em que ele ficou internado. Fui muito bem acolhida pelas mães, estava recémoperada, todas foram muito prestativas.

Conheci uma senhora que foi muito especial naquele momento, que estava lá acompanhando sua filha, como ela disse estávamos todas no mesmo barco, todas acompanhando nossos filhos cardiopatas. Tinha sempre que me manter firme, meu marido estava cuidando da nossa filha e trabalhando, não podia passar o tempo todo em São Paulo comigo, por vários motivos eu não podia contar para ele o que sentia naquele momento, o tempo todo parecia que eu sabia que apesar da boa evolução do nosso bebê, a missão dele seria curta conosco. Graças a Deus, ele reagiu bem nas longas $72 h$ de pós-operatório, dali os médicos já começaram a pensar no fechamento do esterno que ficou marcado para o sétimo dia.

Minha espiritualidade me ajudou muito, fui muito preparada, estava muito tranquila. Ele estava bem, reativo a sedação, mas sabia que não seria naquele dia, coloquei muito na minha cabeça que tudo deveria ser no tempo dele, como foi... No centro cirúrgico 
ele teve uma parada respiratória e teve que ser aberto o tórax dele, confesso que recebi "bem a notícia", havia rezado muito, conversado muito com os médicos e com as outras mães da ACTC, sabia que era uma coisa grave, mas comum não dar certo na primeira tentativa, na realidade estava cercada de uma boa equipe, médica e espiritual. Ele retornou para UTI, foi um dia muito marcante porque ele estava muito reativo a sedação, correspondia as minhas conversas com ele, saí de lá radiante, preferi ir embora mais cedo naquele dia por que ele não podia se agitar. As meninas da assistência social do hospital estavam tentando um transporte na minha cidade para que, ao invés de ficar na ACTC, eu pudesse ir e vir todos os dias para a Baixada, o que não foi possível. Nas minhas vindas para casa fui atrás disso aqui na Praia Grande, mas é muito precária a Saúde por aqui, sempre que podia meu marido ia nos ver, mas o município não nos amparou em nada...

No décimo dia na UTI, foi feita uma nova tentativa de fechamento do tórax, dessa vez realizada com sucesso! Desse dia em diante passei a viver em conflito comigo mesma, pois só fazia aumentar minha angústia, meu coração sangrava cada vez que olhava meu príncipe e não o sentia por completo ali, a cada boletim médico que a cardiologista vinha radiante me falar que ele estava cada vez mais reativo a cirurgia... Mas Deus já me preparava para o pior, eu é quem não queria acreditar! Os dias foram passando, ele sempre respondendo muito bem, cada dia melhor, um dia de cada vez, passos pequenos de acordo com seu tempo, por volta do $15^{\circ}$ dia começaram a diminuir a DPI e já se falava em extubá-lo e, apesar de sedado, ele sempre muito reativo, ele era a sensação da UTI com aqueles cabelinhos arrepiados! Ele passou por cateterismo, que não apresentou nada de novo, mas que me deixou um pouco sem esperanças, suas vias eram tão finas e pequenas por conta da Hipoplasia que foi preciso interromper o procedimento, ou seja, a reconstrução apesar de bem feita não mudou muito o quadro clínico dele... Ele respondeu bem a retirado do tubo, fiquei muito feliz, todos 
ficamos! No primeiro dia nem precisou do CPAP, foi um alívio. Ele respondeu muito bem, já aguardávamos a alta da UTI, foram retirados todos os aparelhos dele, voltou a tomar sua dieta, estava prestes a mamar no peito.

Lembro-me como se fosse hoje: no dia em que ele completou um mês de vida, o médico chefe da pediatria deixou que eu participasse da reunião de boletim médico, brincou comigo perguntando se eu estava preparada para ouvir qualquer coisa e entre eles disse: "espero que o Pretinho não apronte nada, quero dar alta para ele na segunda-feira, quero ele no quarto, já está ótimo, chega de UTI". Eu e as técnicas ficamos radiantes, tiramos fotos, muitas fotos para comemorar o mensário dele e como de costume no início do plantão noturno fui para ACTC, como todos os dias, passei tudo que havia acontecido para o meu marido e, apesar de não demonstrar, fui dormir com um enorme aperto no coração.

Na quinta-feira cheguei mais cedo do que o normal ao HCor, conversei muito com o bebê e, como havia rumores da alta para o quarto as técnicas, me aconselharam a ir para minha casa porque eu passaria a ficar internada com ele o tempo todo. Usei isso como pretexto para sair dali, com o coração na mão me despedi do meu filho, pedi muito a Deus e aos meus Orixás que aquilo não passasse de uma sensação ruim, sai de lá por volta das 10 horas da manhã, a técnica que estava com ele brincou e disse que eu fosse em paz que amanhã quando chegasse ele estaria ainda melhor...

Eu e meu marido passamos o dia angustiados e por volta das 18 horas recebi a ligação pedindo que eu voltasse, pois meu bebê havia tido uma parada respiratória. Apanhei minha bolsa, deixei meu marido para traz, mandei-o levar a nossa filha para alguém e ir para São Paulo na sequência, mas não disse o que havia ocorrido, fui rezando, pedindo para que ele ficasse bem, mas quando eu cheguei dei de cara com os aparelhos já desligados e alguns "mentores" ao lado do corpo físico dele. Não gritei, não chorei, não via e nem ouvia ninguém naquela hora além daquele rostinho sereno, peguei o 
corpinho dele no colo, senti as lágrimas rolarem no meu rosto, algumas pessoas falavam comigo, mas eu não respondia, lembro que fiquei calada por um bom tempo... Até que meu celular tocou, era meu marido dizendo que já estava descendo a serra com a minha sogra, eu disse que estava tudo bem, não queria assustá-lo no trânsito, mas minha sogra Yalorisà já sabia que eles não chegariam a tempo de vê-lo com vida, mas por sua vez se calou. Mantive a calma para poder acolher meu marido, fiquei com meu filho o tempo todo, as enfermeiras o batizaram durante à tarde, o que me deixou muito revoltada, porque se ele já apresentava maus sintomas durante o dia eu deveria ter sido comunicada. Eu estava lá todos os dias e quando saia avisava para onde ia, andava com todos os telefones ligados, eu deveria ter sido avisada, se pensaram em batizá-lo era porque o quadro se agravou mais do que o esperado... Fiquei com seu corpinho o tempo todo, cuidei de todos os detalhes enquanto meu marido voltou para Baixada para cuidar do velório, arrumei forças de onde nem sei que tinha, até o final do enterro, onde meu mundo desabou...

O tempo em que estive no HCor fui muito bem amparada pela equipe do HCor, as técnicas foram maravilhosas, o pessoal da ACTC foi excelente cuidou de todos os detalhes do traslado, a psicóloga do hospital foi maravilhosa, apesar de depois da partida do bebê não ter realizado nenhum contato comigo. Queria ter saído com meu filho do HCor e espero com a minha experiência poder ajudar outras mães!"

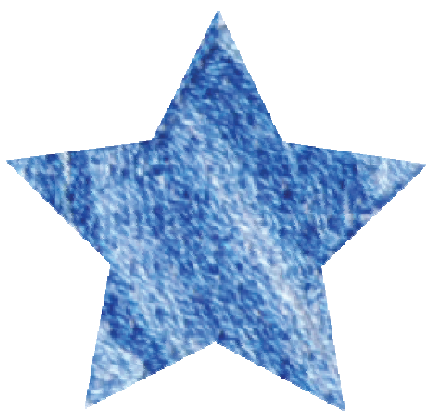

Bebê da E6 foi a óbito no dia 30 de maio de 2013, com 31 dias de vida... A equipe multidisciplinar apostava muito na alta deste bebê, pois sua evolução era muito boa, sua morte foi sentida por todos. 



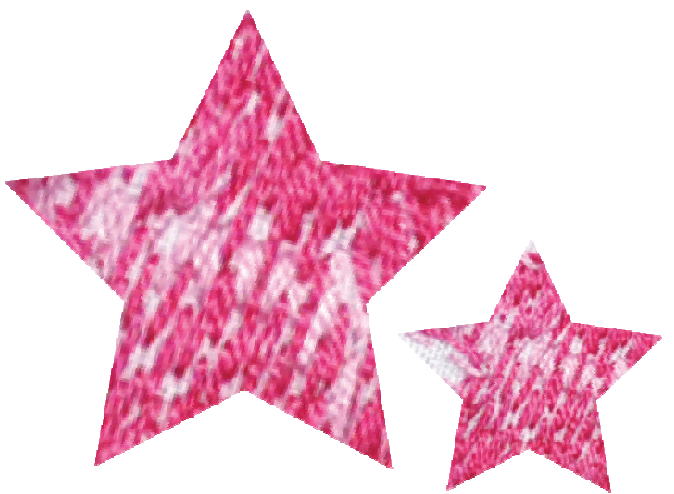

E7 tem 19 anos, ensino médio completo, é natural de Praia Grande (SP), é casada e é católica. Espera sua primeira filha, a qual foi planejada, porém a descoberta da cardiopatia tem sido motivo de muitas incertezas... 



\section{Data: $\mathbf{3 0 / 4 / 2 0 1 3}$}

\section{Horário: 15 horas}

"A minha gravidez foi planejada e desejada e saber que o bebê terá um problema no coração não está sendo fácil. É o meu primeiro filho, tive dificuldade para engravidar devido a um problema de cisto de ovário e endometriose, então quando fiquei grávida não imaginei que fosse ter um bebê com uma cardiopatia, ainda mais na primeira gestação.

Sou de Praia Grande, comecei a fazer meu pré-natal lá e no início foi tudo muito tranquilo. Comecei a ficar ansiosa quando descobri que tinha que vir para cá, porque não imaginava que ia mudar a minha rotina, achei que ia ganhar ela lá no hospital que tenho convênio. Descobri quando fiz um ultrassom morfológico lá mesmo, com 20 semanas, para saber tamanho, peso, e então descobri também o problema no coração e foi indicado um ultrassom ecofetal. O médico de ultrassom ecofetal de lá também viu a patologia e ele mesmo me indicou a vir para São Paulo. Fiquei perdida, não sabia como vir, mas tive a sorte de ter uma prima que trabalha no HCor e que me ajudou a chegar aqui.

A primeira vez que vim a São Paulo foi no dia 3 de março para encontrar a médica cardiologista no Dante Pazzanese. Fiz uma eco e ela me encaminhou para o HCor. Passei pela assistente social e teve toda a burocracia da documentação. Quando me ligaram avisando que tinha dado tudo certo, que estava autorizada a documentação, então comecei a passar por toda a equipe médica, e até pela psicóloga.

O nome da cardiopatia não sei, sempre me confundo, mas na verdade o coração dela não se formou totalmente. Tem uma parte que está menor que a outra, então o oxigênio e o sangue não estão passando onde deveriam, está bombeando tudo para o outro lado, só passa pouquinho de sangue. Eles me explicaram que na verdade a cirurgia vai ser para ela se adaptar ao próprio coração que ela mesma gerou. Estou conversando com os médicos para tentar 
entender, porque a ficha ainda não caiu, é difícil de entrar na cabeça, quando falam patologia grave, é difícil de aceitar, não aceitei totalmente não...

A familia está dando apoio, minha mãe, meu pai, meu marido, eles dão bastante apoio para eu tentar ficar calma. Sou muito ansiosa, quando lembro começo a chorar e desanimo, fico triste e eles tentam todos me colocar para cima. O meu marido é mais reservado, não é como eu que chora na frente de todo mundo, é de ficar no cantinho dele, chora sozinho, primeiro filho dele também, está preocupado.

No início da gravidez tive muito enjoo, agora nem tanto, mas no começo tive enjoo do que mais gostava que era tomar leite com achocolatado, então tomar café de manhã estava muito difícil. Agora desejos não tive nenhum, pensei que iria ter, mas não. Toda a minha família brinca, ela já comia naturalmente, grávida então vai comer por dois. Imagina tudo que é verdura, estou adorando comer, muita coisa que não comia aprendi a comer, detestava beterraba e hoje gosto por causa dela, porque faz bem para ela, tudo tranquilo com minha alimentação.

Ela mexe e me chuta muito, nossa senhora, tanto que já está quase encaixadinha. Já entrei no sétimo mês, então ela já está se encaixando e é engraçado porque a gente conversa e ela entende, a gente fala para mexer e mexe, para chutar e chuta, é muito gostoso, é o que me conforta. Mas saber que ela vai nascer e vai para uma sala de cirurgia não entra na cabeça, ainda é muito novo, acho que só vai entrar mesmo na hora que eu ver que ela foi.

Passei na consulta com a enfermeira e foi tranquilo, só que é muita informação para a minha cabeça. Pensar que vou vir para cá então, ainda não estou aceitando, mas é como meu marido falou, se é para o bem dela, para ver que ela vai voltar para casa com a gente, a gente vai ter que ser firme, ser forte. Provavelmente terei que voltar com 35 semanas para passar com obstetra, tudo direitinho, mas tem que ver a data porque na verdade vou ficar 
instalada na ONG Pequenos Corações perto do hospital, que ainda vou conhecer. Para mim, ficar subindo e descendo já está cansativo (referindo ao fato de vir da Baixada Santista), então vou saber quanto tempo terei que vir antes, mas passa rapidinho, daqui a oito semanas praticamente. A gente está ansioso para ver o rostinho dela, para saber como ela é, com quem se parece.

O apoio da família tem sido grande, ela ganha muita coisinha todo dia, roupa, fralda, sapatinho, todo mundo fala nela, liga para saber como estou e como ela está. Isso está me dando força, porque no começo foi difícil, fiquei com o psicológico muito abalado, não esperava, tanto que estou praticamente afastada do serviço. $\mathrm{Na}$ verdade vou passar com a minha obstetra com quem faço o prénatal e ela vai me dar o atestado para entrar em licença pois o trabalho no comércio é muito estressante. Ficava muito tempo em pé, não tinha cadeira para sentar, às vezes queriam que eu fizesse hora extra, passava do horário e sentia muita fome, saia de lá debilitada, cansada, nervosa, pois querendo ou não é cliente estressando a gente, funcionário estressando, era uma pressão psicológica muito grande. Em casa tinha o apoio da família, mas no serviço eles tratavam a gravidez como se fosse nada, falavam que eu não estava doente, estava apenas grávida. Se eu faltasse e passasse um atestado no dia seguinte era piada o dia inteiro, ficava aquela coisa de dó, não tinha apoio pelo problema da nenê, estava muito difícil trabalhar. Então ficava só afastando, de atestado, trabalhava um dia me afastava mais dez e então agora vou entrar definitivo em licença, ainda mais na reta final, sem condições de voltar a trabalhar.

Para a minha mãe no começo foi um susto, é a primeira neta dela, acho que não imagina porque é daquelas mães que ficavam sempre em cima. Quando morava com ela (faz dois anos que não moro mais com a minha mãe porque me casei), ela sabia certinho o dia que descia para mim, sabia o dia que acabava o anticoncepcional, se acaso atrasasse já perguntava se eu estava 
grávida. Mas dessa vez, como saí da casa dela, não tinha mais aquela rotina de me espionar, então foi uma surpresa, aí eu fiz o quê? Comprei duas roupas de recém-nascido com "sou da vovó" e "sou do vovô". Quando cheguei com a roupinha de bebê ela não entendeu, falei "mãe, olha o desenho", ela viu e falou "vou Ihe matar" porque eu estava com o casamento marcado. Descobri que estava grávida em novembro e ia casar em abril, e me disse "Mas o vestido nega?”, eu falei "mãe, eu já sabia, por isso que falei que o vestido era para casar com barriga", "sua safada, já sabia de tudo e não me contou nada", se eu contasse não era surpresa.

No começo ela e o meu pai ficaram meio assustados. Agora a minha mãe todo dia liga, todo dia comenta com as amigas dela, fala da bebê, compra presente, meu irmão e minha irmã também, está sendo a primeira vez que eles vão ser tios. A minha irmã é mais reservada, ela dá atenção, mas é reservada, tem 20 anos. O meu irmão de 11 anos é um grude, porque assim, a minha mãe sempre trabalhou, então criei os dois. Ajudei a alimentar, eu que ajudei nos estudos, porque a minha mãe vivia o dia inteiro fora de casa trabalhando, então eles cresceram comigo, sempre me chamavam de mãe dois, nunca me chamavam pelo nome. Agora que estou grávida no começo ele ficou com ciúme, achou que não ia gostar dele mais do mesmo jeito, aí falei "não, irmão, vou amar você do mesmo jeito que sempre amei, só que agora vou amar do mesmo jeito a bebê também, vão ser duas pessoas para eu dar atenção, você e ela”. Então chego à casa da minha mãe e ele começa a beijar a minha barriga, começa a conversar com ela, é bem legal, não fica uma hora sem falar com a minha barriga, ele vem e abraça, conversa.

Meu casamento foi no sábado agora. A gente foi tirar fotos com um fotógrafo e estava todo mundo entrando no carro quando meu irmão colocou a mão na minha barriga e começou a chorar, porque me viu chorando na igreja quando entrou com as alianças. Eu ficava falando "será que a minha nenê vai ver a minha fita de casamento"? 
E aí ele começou a chorar e falou "irmã, será que eu vou conhecer você", foi um momento muito forte, bonito, mas na hora chorou todo mundo, ninguém esperava, graças a Deus tenho o apoio de todo mundo. Casei na igreja católica, o civil foi de manhã e na igreja foi à noite. Só que não viajei porque a nenê não deixou, falo para a minha família que a lua de mel vai ser com ela, ela quer que vamos os três viajar juntos quando ela tiver maiorzinha.

O meu irmão tem sopro no coração, é cardíaco. A minha mãe explicou que a nenê poderia ter um problema por ser de família, porque realmente ele também tem um problema no coração, tanto que faz acompanhamento no Hospital das Clínicas, todo o ano ele vem para cá. No começo não entendia, ele me via chorando e queria saber o que estava acontecendo, foi realmente quando a minha mãe contou para ele, aí ele perguntou se a nenê tinha mesmo um problema no coração. Respondi que sim, aí ele chorava, parecia um bebê chorando, mas está dando força, é bem esperto, inteligente, não comenta o assunto, mas sabe o que está acontecendo, sabe se comentar eu fico nervosa, essas coisas assim. Agora mima muito a nenê, a barriguinha ele fica beijando, colocando o ouvido para tentar ouvir o coração, bem legal.

A minha prima falou para mim que vai ser uma experiência de amadurecimento porque por mais que eu tenha experiência, sou casada, tenho a minha casa, já tenho aquela vida fora dos pais, ainda tem aquela menininha por dentro, aquela coisa da menina... “Vai ser bom porque vai ser uma experiência de amadurecimento para você, vai se tornar mesmo mãe, deixar de ser aquela menininha, conhecer outras mães, vai saber, ter experiência, outras mães vão conversar com você sobre os bebês que estão internados, você vai conhecer, vai dividir a sua trajetória, onde vai crescer e amadurecer, isso vai ser o legal, vai ser uma experiência que vai levar para a vida." Aí é onde fico mais tranquila.

Eu converso muito com ela, com a barriga, se deixar fico o dia inteiro falando. Às vezes ela fica quietinha, tem dias que falo "Minha 
filha, não vai mexer não"? Falo que, se ela mexer, fico tranquila, se ficar quieta, acho que alguma coisa está acontecendo. Então, falo para ela ficar o dia inteiro mexendo. Às vezes é engraçado quando ela fica quietinha o dia inteiro e o meu marido chega em casa, ele abre a porta, fala que chegou e ela já começa, sente que ele chegou, ele beija a barriga, fala "neném, o papai chegou" e ela se mexe e não para, aí eu começo a conversar com ela e ela responde, acho muito engraçado, muito gostoso."

\section{Data: $19 / 7 / 2013$}

\section{Horário: $11 \mathrm{~h} 30$}

"O nascimento da minha filha foi uma coisa inesperada, porque ela nasceu antes da hora, era para nascer dia 3 de julho e nasceu no dia 18 de junho. No dia 16 de junho foi o chá de bebê dela, quando acabou fui para casa e falei "ah, devo estar com dor por causa da agitação", tinha me movimentado bastante e pensei "vou tomar um banho e relaxar", deitei um pouco na cama e então a dor começou a aumentar. Eu olhava no relógio e estava de dez em dez minutos, falei "não, não estou com contração, não pode ser", e tentei dormir mais um pouco. Quando foi $1 \mathrm{~h} 30$ da madrugada a dor começou a aumentar, fui para o chuveiro tentar jogar um pouco mais de água na coluna e chorava, chorava. Meu marido falou "vou ligar para sua mãe e a gente vai para o hospital", eu falei "não, mas não é nada"! Ele falou "você está chorando, como não é nada"?

Cheguei lá no hospital do meu convênio onde moro e o médico examinou e falou "mãe, você está com contração sim, só que você não vai dilatar". Fiquei a noite inteira na unidade, a madrugada inteira internada. Às 8 horas da manhã fiz um ultrassom, que acusou que estava perdendo líquido e ela estava ficando sem espaço. O médico perguntou "mãe, você vai ganhar ela aonde? Aqui ou tem que ser em São Paulo"? Falei "ela tem que nascer em São Paulo". Então meu pai foi fazer toda a burocracia da ambulância, mas 
cobraram três mil reais para me transferir de lá até aqui de ambulância, meu pai falou "três mil reais de ambulância? Não, pode deixar que eu carrego ela aqui no meu carro, eu mesmo levo ela”. Meu pai me colocou no carro dele mais a minha mãe e o meu marido. Quando chegou à entrada da Imigrantes tem um posto rodoviário, ele explicou para o policial o que estava acontecendo e o policial falou "me segue atrás da viatura porque vou sair correndo por esta Imigrantes". A viatura veio com a gente com aquela buzina e aquela sirene, a contração estava de cinco em cinco minutos, aí foi aumentando, a minha mãe estava gritando para o meu pai acelerar o carro e eu estava gritando para ele diminuir, porque estava morrendo de medo dele correndo com o carro.

Cheguei ao Hospital das Clínicas aqui em São Paulo às 14 horas da segunda-feira do dia 17, fiquei das 14 até as 21 horas da noite fazendo exame de toque para ver se eu ia dilatar e nada, nada de dilatar. Às 22 horas fui internada e fiquei a madrugada inteira na cardio para ver a frequência cardíaca dela. Às $14 h 30$ do dia 18 fui para o centro cirúrgico e ela nasceu às 15 horas, só que não a vi. Foi muito difícil porque no Hospital das Clínicas não deram muita informação para o meu marido sobre onde eu estava, o que eu estava fazendo, que horas que ia ser. Então o meu marido na hora da cesárea não estava comigo porque não conseguiram achar ele, tive a cesariana praticamente sem ninguém ao meu lado, meu marido não assistiu o nascimento da nossa filha, ficou aquela coisa assim só médicos do meu lado. Comecei a chorar porque o meu marido não estava junto comigo e já comecei a ficar mal porque pensei que estava acontecendo alguma coisa. Não tinha visto ela, mas ela já estava sendo transferida para o HCor e ninguém tinha falado nada. Nenhuma informação, bem difícil, foi bem complicado!

Fui conhecê-la três dias depois. Minha mãe ficou comigo no Hospital das Clínicas e meu marido ficou com a nenê no HCor. Ele ficou indo e vindo, eles falavam pelo telefone "ah, ela é parecida com você, tem sua cara, sua boca", só que eu falava "O que adianta 
vocês falarem se eu ainda não vi? Quando eu ver vocês podem falar, aí eu concordo se parece ou não". Quando tive alta, vim para cá conhecê-la, foi questão de minutos ela já desceu para a primeira cirurgia, que foi o cateterismo no dia 21 de junho.

A recuperação foi boa, mas o stent que colocaram não deu certo. O canal do coração dela é muito largo, estava indo muito sangue para o pulmão, quando tentaram extubar ela não tinha respiração suficiente e estava tendo parada respiratória. Então levaram para a cirurgia e tiraram o stent e colocaram o blalock taussing, que é um tubinho (com a função de direcionar o fluxo de sangue para os pulmões e aliviar a cianose, enquanto a criança está à espera de cirurgia corretiva ou paliativa). Ela já se recuperou, graças a Deus, operou na sexta-feira passada, foi cirurgia mesmo, de abrir o peito e tudo. Nessa cirurgia fiquei mais apreensiva, com medo, porque abre o peito, e ela tinha menos de um mês ainda, estava com 24 dias. Mas, graças a Deus, a recuperação foi boa, tirou o dreno, a cicatrização do curativo do peito já fechou, tudo certo. A única coisa que tentaram fazer foi extubar ela ontem, mas não conseguiram porque o médico falou que deu nos exames que ela está com infecção nos pulmões. Então está no antibiótico agora e vamos dar mais um tempo, só vão tentar extubar de novo quando estiver cem por cento.

Da equipe não tenho o que reclamar, a minha filha tem mais tratamento "vip" do que eu quando era pequena. Penteiam o cabelinho, colocam uma presilhinha, é xampu bom, hidratante no corpo, manteiga de cacau, tudo assim, chiquisinho para ela. Eles têm um cuidado, um amor, pelo menos todo enfermeiro ou enfermeira que conheci, que cuidaram da bebê, não tenho o que reclamar, o mesmo carinho com ela, a mesma atenção e cuidado, não tenho o que reclamar mesmo. Nem falo que é um hospital, até brinco que é um hotel, você não se sente num hospital, graças a Deus, a minha filha está em um lugar ótimo. 
Estou ficando na casa de apoio, a ACTC. Nos primeiros dias foi difícil porque não conhecia ninguém, até acostumar com a casa... E perceber que estava longe da minha família, foi difícil. Mas agora acostumei e até brinco que a ACTC é a minha segunda casa. Quando vou para a minha cidade falo "tchau, gente, estou indo para a minha segunda casa". Mas passo o dia inteiro no hospital, uso a casa de apoio mais para dormir mesmo, saio de manhã e chego à noite, só tomo banho, no outro dia de manhã já estou saindo de novo, minha rotina é toda aqui no hospital.

Entro nos horários de visita para vê-la. Depois vou almoçar dar uma volta na rua para não ficar o dia inteiro enfiada dentro do hospital, a gente fica doida... Vejo ela um pouquinho e depois fico na sala da internet, descontraindo a cabeça. Meus familiares ficam todos online, conversando por mensagem e é onde fico mais tranquila, mas agora eu estou bem, estou calma. Só estou meio triste porque ela está com infecção no pulmão, não gostei da notícia que recebi no boletim médico de hoje, mas ela vai ficar bem.

Meu marido tem vindo somente no final de semana porque trabalha. Só este final de semana que não vai conseguir vir porque vai ter que trabalhar no domingo. Mas todo sábado e domingo ele está aqui para vê-la. No dia 16 de julho às $2 h 30$ da madrugada, segunda para terça-feira, a mãe dele faleceu. Agora ele está um pouquinho mais para baixo, um pouco triste por ter perdido a mãe, já não é a mesma pessoa que antes. Aí quando eu ligo para falar que ela não está muito bem, ele fica mais murchinho. Então a gente estava feliz, empolgado com a extubação dela ontem, liguei para ele e falei "olha, ela vai ser extubada, vão tirar do tubo", mas não deu meia hora e voltou para o tubo de novo, não aguentou ficar sem. Tive que unir forças, ligar para ele e falar "ela voltou, não conseguiu". Então para ele é muita coisa, além de perder a mãe, ele era muito unido com a mãe, ainda a filha na UTI de hospital, a cabeça dele agora está bem mais difícil do que a minha. Sou eu que tenho que ser forte e dar força para todo mundo. 
Por conta disso o meu leite deu uma "sumida". Desde o dia que ela nasceu não sei o que é o choro dela, não ouvi o choro dela até hoje, não sei o que é pegar no colo... Ela está há um mês naquela UTI, nunca peguei no colo, não sei o que é amamentar, porque ela nunca estimulou, nunca conseguiu sair do tubo, então o leite dá aquelas variadas, tem hora que está muito, tem hora que não tem nada. Estou tendo que tomar remédio para conciliar para o leite não parar, vou para a sala do banco de leite de três em três horas, embora às vezes não saia muito, vou porque estimula, bem pouco, mas estimula para não secar, para quando ela for vir a amamentar eu ter leite para ela.

Estou me alimentando bem, tomo café e meio dia em ponto vou almoçar, se passa cinco minutos já começa a doer o estômago porque já estou acostumada com a rotina. Almoço no restaurante Cubatão com as outras mães que são da ACTC e à noite a gente janta cedo no refeitório do hospital, entre $18 \mathrm{~h} 30$ e 19h. Convivo com outras mães, pena que não conseguimos participar da reunião da UTI pediátrica, o táxi atrasou e quando chegamos aqui já tinha acabado, estamos tentando ver quando será o próximo dia.

É bom conviver com outras mães, é bem diferente, é legal porque às vezes tem o mesmo problema, às vezes conhecemos outros problemas que nem sabíamos que existiam, são vários diagnósticos, nem todo bebê tem o mesmo diagnóstico, então você vai conhecendo cada tipo de cardiopatia... Na sala de espera da UTI do quinto andar é bom porque você nunca fica sem conhecer ninguém, todo mundo que chega começa um a conversar com o outro, não tem aquela coisa de isolamento, ali todo mundo chega, se conhece, pergunta de onde veio, porque está aqui, qual problema tem, qual leito está, a gente já conhece o nome de todo mundo. É bem diferente lá, principalmente na neonatal, onde a minha filha está, já conheço todas as mães e os bebezinhos que estão ali, quem é mãe e quem é pai de um por um. 
A cardiopatia dela é isso aí, ela já fez a primeira cirurgia e agora daqui a seis meses vai fazer outra. A segunda cirurgia é de quatro a seis meses, mas ainda não disseram o mês exato, e a terceira e última cirurgia, porque no caso dela são três mesmo, é com dois anos. Como ela teve má formação no coração, vão fazer esses três procedimentos para ela se adaptar ao próprio coraçãozinho, e não precisar necessariamente de um transplante. Então vão tentar reabilitar ela a seu coração e ela continua seguindo a vida normal como todo mundo."

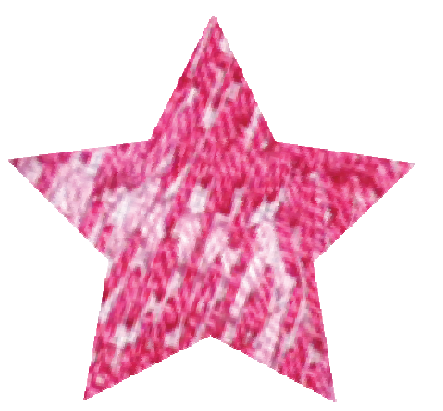

Bebê da E7 recebeu alta no dia 24 de agosto de 2013, com dois meses e seis dias de vida, com boa evolução. Com retornos ambulatoriais quinzenais ao HCor. 



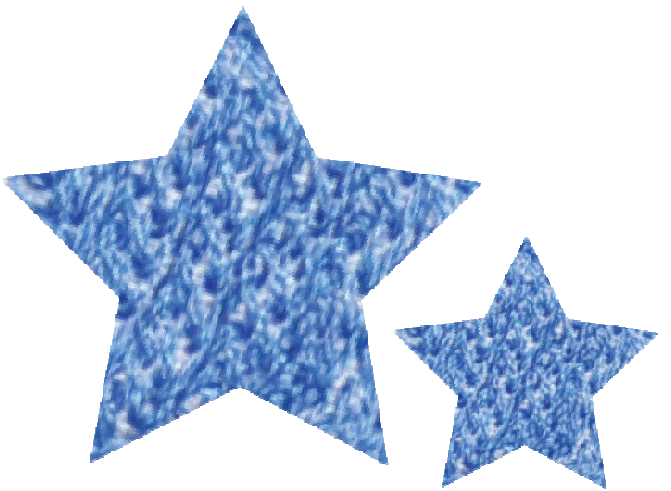

E8 tem 35 anos, ensino médio completo, é natural de São Paulo (SP), é divorciada e é evangélica. Esta é a quarta gravidez, não queria ter mais filhos e agora espera um menino. 



\section{Data: $18 / 6 / 2013$}

\section{Horário: 11 horas}

"Há doze anos casei grávida, mas perdi o bebê que nasceu de seis meses e não sobreviveu... Hoje tenho duas filhas, uma de 11 e uma de seis anos. No pré-natal do primeiro bebê não tinha nada. Fazia o pré-natal no posto, nunca tinha médico, ultrassom nunca tinham pedido. Depois de sete meses que ele faleceu, fiquei grávida de novo e foi só apreensão, medo de tudo, sentia dor, mas, graças a Deus, não tinha nada, foi tudo psicológico.

A segunda filha eu tive quase cinco anos depois da primeira, também de parto normal, a gestação foi mais tranquila. Fiz o prénatal direitinho, acompanhei, foi em outro posto de saúde e a médica me deu bastante atenção, graças a Deus, não tive nada. Ela também nasceu no Hospital da Vila Penteado, os três nasceram no mesmo hospital. Amamentei as meninas, a primeira mamou até 11 meses e a segunda até uns três, quatro meses, mamou pouquinho porque já tive que trabalhar logo, na época era manicure, hoje além de manicure, trabalho com telemarketing.

Agora estou esperando um menino, esta gravidez não foi planejada. Tenho esclerose múltipla e tomo medicamentos e acredito que me atrapalhei com o anticoncepcional. Descobri que estava grávida no começo de dezembro, em janeiro fiz o ultrassom, descobri que tinha alguma coisa errada. A princípio achava que era algum tipo de síndrome, fiz biopsia da vilo corial e não deu nenhuma síndrome, graças a Deus! Nenhuma alteração cromossômica, foi descoberto que era SHCE. Como tenho convênio, foi tudo pelo convênio, fiz o primeiro morfológico no primeiro trimestre e deu essa alteração. Foi na mesma semana que fiz a biopsia e vi que não era síndrome, fiz outro ultrassom e descobri que era um problema no coração.

A minha prima teve um bebê que também era cardiopata, só que o dela não sobreviveu. Ela me apresentou a ONG Pequenos 
Corações e pelos Pequenos Corações consegui fazer uma eco no Instituto Dante Pazzanese com a médica cardiologista aqui do HCor, que me encaminhou para cá. Faço pré-natal pelo convênio, pelo posto e agora ela me encaminhou para cá, fiz tanto ultrassom que quando ele nascer já vai sair fazendo pose para foto (risos). A cardiologista me explicou como iria ser tudo, falou sobre o problema da cirurgia que ele terá que fazer quando nascer. Juntei os documentos, trouxe e fiquei aguardando ser chamada e nisso acompanhando o pré-natal, fazendo outros ultrassons, fiz o eco também pelo convênio e tudo confirmou, nada diferente.

Já tinha escutado falar sobre cardiopatia porque a minha prima, como Ihe falei, teve um bebê cardiopata não tem muito tempo. Ela não seguiu direito o pré-natal, apesar de ter convênio e também acesso ao posto de saúde, não seguia direito as consultas e não conseguiu fazer o morfológico, só fez o ultrassom obstétrico que não consegue ver nada, não aparece nada, então ela não descobriu, só descobriu mesmo quando ele nasceu. Ele nasceu no Hospital Metropolitano pelo convênio e, 24 horas depois que tinha nascido, a médica examinando descobriu que tinha essa SHCE e outras coisas também, outras malformações. Foi transferido para o Hospital da Luz, que a princípio é onde eu faço o pré-natal também, e na cirurgia ele não sobreviveu. Então por ela eu já sabia que existia esse tipo de coisa, até então na família ninguém tinha escutado falar e quando descobri a cardiopatia do meu filho fiquei maluca, falei "meu filho vai morrer! Ai meu Deus"!

Hoje estou mais conformada, mais otimista. Até pouco tempo atrás não estava não, para mim ele não iria sobreviver, por causa do dela, mas são doenças diferentes, cardiopatias diferentes, grave, mas histórias diferentes. Agora é pensar em fazer acompanhamento no HCor, aliás, outro dia a médica que me atende saiu na capa da Veja São Paulo, como assino, chegou a Veja para mim, dei uma olhada e já mostrei "olha gente, ela vai me ajudar a ter o meu filho", fiz a maior propaganda. Quando conheci essa médica me senti mais 
segura, no dia do eco, ela me explicou o que era a doença dele, como seria feita a cirurgia, quantas cirurgias seriam preciso se desse tudo certo, talvez precisasse mais, e me encaminhou para cá, já fiz duas eco com ela e vou fazer outra aqui.

Aqui fui recebida pela equipe da hospitalidade, conheci a UTI (fiquei bem triste), conheci a psicóloga, a enfermeira, na verdade não conheci muita coisa, foi mesmo a UTI e os quartos. Ainda não passei com o obstetra daqui para marcar o parto, se fosse normal nasceria até 12 de agosto de 2013, mas vai ter que adiantar um pouco, estou com oito meses e já estou com um pouco de dilatação, por isso estou de repouso.

Falo com o bebê todo dia para ele ficar aqui quietinho, sossegado, porque aqui ele está bem, depois que nascer é outra coisa. Mas ele também não pode nascer antes, tem que nascer no dia certo. Ele mexe bastante, mas quando está quietinho já me preocupo. Hoje mesmo não mexeu muito, comentei com a psicóloga "hoje ele estava quietinho, mas estou assim, se parar de mexer de vez, já sei que tenho que correr".

Não moro com o pai do bebê, ele é meu namorado, mora em Santos e vem para cá no final de semana. Está apreensivo e ansioso também por ele nascer. Também estou ansiosa e ao mesmo tempo com medo dele nascer muito antes. Não pretendo morar junto com o pai do bebê, está bem assim, ele fica lá e eu aqui e tudo bem, é melhor assim. Já fui casada, sei que não é uma coisa boa forçar um relacionamento por causa de um filho. Casei grávida do primeiro e em um mês de casada perdi o neném, então não valeu muito a pena ter casado. Depois vieram as meninas e não deu certo, segui a minha vida e ele a dele. Então não quero cometer o mesmo erro de novo, deixa do jeito que está que está muito bem, se um dia a gente casar, morar junto, sei lá o que vai acontecer, mas não agora por causa do bebê. As meninas estão felizes com a chegada do irmão, principalmente a pequena que fala mais, a meu irmãozinho isso, 
meu irmãozinho aquilo. A mais velha puxou o pai dela, é mais seca, já a pequena é mais amorosa.

Não tenho pensado muito no futuro do meu filho, depois que descobri a cardiopatia fiquei preocupada. Até pouco tempo atrás estava muito pessimista, completamente pessimista, pensava "meu filho não vai viver, tenho que me preparar, já enterrei um e vou ter que enterrar outro"... Agora não! Agora já estou um pouquinho mais otimista, com medo, mas otimista. Não estou fazendo muito plano para depois que ele nascer, vou deixar porque de repente imagino uma coisa e é outra, então não quero sofrer, vou deixar para sofrer na hora que tiver, já sofri bastante antes, por enquanto vou deixar "dançar conforme a música" e é isso por enquanto.

Já fui católica, espírita e evangélica. Falo que hoje não vou para lugar nenhum e não sigo religião nenhuma. Acredito em Deus e é com ele que converso sempre em relação ao meu filho para me ajudar a aguentar o baque, aguentar quando ele nascer o que tiver que acontecer e vou me fortalecendo nisso. Deus está me ajudando bastante, falo que se não fosse ele, de tanta coisa que me aconteceu, não teria aguentado. Acho que Deus me testa bastante, já tem 13 anos e desde então nunca fui normal, nunca mais fui a mesma, foi isso que aconteceu. Quando foi 2011 descobri que tenho esclerose múltipla e de novo Deus está me testando, e agora é isso... (choro)."

\section{Data: 8/8/2013}

\section{Horário: 16 horas}

"O bebê nasceu aqui no HCor no dia 29 de julho às $8 h 47$ da manhã e foi muito legal, a recepção do pessoal do hospital, a hospitalidade da equipe da enfermagem. Eu esperava por um tipo de anestesia e foi dado outro por conta da minha doença, na verdade a médica anestesista ficou preocupada que depois que ela me desse à anestesia demorasse muito para voltar meus movimentos ou não 
voltassem por causa da esclerose, por isso optaram pela anestesia geral. Fiquei desesperada na hora que ela colocou o aparelhinho, falou que era oxigênio já comecei a sentir falta de ar, pensei "vou morrer" (risos), e apaguei. Quando acordei o meu filho já tinha nascido, não o vi de imediato, tive muita dor, fiquei na UTI em observação. Eu sempre falava que parto normal doía demais, não queria ter parto normal, achava que cesárea não sentiria dor, mas pelo fato de ter tomado a anestesia geral senti muita dor, dor na barriga, não podia me encostar na cama que já sentia dor. Receitaram um remédio mais forte, mas mesmo assim demorou ainda para melhorar, como fui entubada por causa da anestesia, irritou a minha garganta, comecei a tossir, olha, foi um caos... Ainda sinto dor, mas bem menos, falo que não posso sentir dor, não posso sentir nada porque tenho que cuidar dele... Então, vou me segurando.

Quando fui para o quarto, chegando lá já vi as fotos que foram tiradas na hora do parto, que o pai tirou, a psicóloga também tirou. O pai do bebê me contou como foi, desde a hora que ele entrou na sala até a hora em que o nenê foi levado para a UTI, ele entrou um pouquinho com o nosso filho, mais depois foi me procurar porque até então não tinha notícias minhas. Só conheci meu filho no dia seguinte que ele nasceu, me apaixonei, lógico (risos). A gente esperava que ele tivesse ruim, mas não, estava ótimo, para o tipo da cardiopatia, estava melhor do que o esperado, conseguiu ainda ficar um tempinho sem oxigênio depois que nasceu. O meu companheiro conseguiu entrar para vê-lo junto com meu pai e as minhas irmãs, conseguiram vê-lo sem aparelho nenhum, sem oxigênio, sem nada, demorou ainda para colocar e quando eu vi, ele já estava com oxigênio, mas perfeito, um bebê perfeito.

O pai do bebê está todo bobo, feliz, fica falando "ah, meu filho, você é bonito! Oh, menino bonito!" (risos) e aí o avô (meu pai) fala "ih, já está chocando o ovo" e ele repete "meu filho é lindo! meu filho é lindo"! Eu falo "calma, calma" e ele reforça "o meu filho é lindo"! Na 
verdade está todo mundo bobo, que é como falei, a gente esperava uma criança doente e ele não parece. A cardiopatia dele é SHCE com atresia pulmonar e foi feita a cirurgia no dia 31, no dia da minha alta. Foi aquela tensão, mensagem para um, mensagem para outro e todo mundo em oração, até falo que tenho que levá-lo em quatro igrejas para apresentá-lo de tanta oração que foi feita. Graças a Deus, deu tudo certo, a cirurgia, o pós-operatório, ele ficou pouco tempo na UTI, já está aqui no quarto e já vai embora, então é só alegria.

Ele é um guerreiro, agora tudo depende dele, tenho todos os cuidados do pessoal daqui, mas depende dele a recuperação, ele ficar bem também. Ele vai fazer o segundo estágio (referindo-se a segunda cirurgia) entre seis e nove meses, o médico explicou, mas como na hora que ele veio dar a notícia eu estava tão emocionada, porque a cirurgia estava terminando e até então tinha sido um sucesso, não entendi muito bem, mas ele vai fazer outra cirurgia que não sei lhe dizer e pode ser que depois dessa ainda tenha outra, quando ele estiver maiorzinho, mas uma cirurgia depende da outra, do sucesso da outra.

Aqui no hospital está sendo tudo tranquilo, estou amamentando, no início fui até a sala de coleta de leite materno e tentei tirar leite, mas não tive leite no dia. No dia seguinte o meu peito começou a encher, depois da cirurgia dele comecei a sentir que já saia leite, isso foi no dia 31. No dia $1^{\circ}$ vim aqui visitá-lo na UTI, ver como ele estava e já comecei a tirar o leite. Desde esse dia estava tirando até que ele mamou a primeira vez. Cheguei ainda a tirar aqui, esvaziar um pouco, senão ele podia engasgar, tirei um pouco de manhã e de tarde ele mamou no peito, normal, então parei de tirar. Foi emocionante quando ele começou a mamar, lógico, com todos os filhos a gente tem aquela emoção de amamentar, mas com ele foi diferente porque imaginava que não ia mamar tão cedo. Ficava pensando que quando ele pegasse o peito já nem teria leite, porque mesmo tirando na bombinha não é a mesma coisa. Quando 
a fonoaudióloga falou que ele podia mamar, falei "nossa, que bom!" e já me preparei. Rapidinho ele pegou, mamou bastante, mas também recebe mamadeira porque não estou vencendo e o meu seio já está machucado, dói bastante na hora que ele pega. Estou passando leite no seio, na verdade um deu uma rachadinha minúscula, doem os dois, mas foi só um machucadinho de nada, essa dor sei que vai passar, com as meninas doeu também, fazia careta, mas passava.

As meninas estão ansiosas, não veem a hora de conhecê-lo. Queriam vir, mas como tem previsão de alta não vou nem trazer, melhor é esperar em casa que aí já pega, já fica um pouquinho, aqui tem que ver bem rapidinho, e em casa é melhor. Elas só viram as fotos de quando ele nasceu e ele já está muito diferente, vou lhe mostrar depois, está muito diferente do dia que nasceu elas não conhecem ainda!

Ele também toma mamadeira porque mama, mama, e não está satisfeito, então tem que apelar para a mamadeira por enquanto. Vou ver se em casa consigo controlar porque em casa a gente fica mais a vontade. Posso deitar com ele na minha cama, aqui não dá, o coloco ali, fico sentada e ele dorme, se eu deitar ele acorda, em casa ele vai deitar junto comigo. Há dois dias não durmo, chega a noite, fico só o pozinho, porque quando ele dorme e o coloco lá se eu deitar ele acorda, parece que sente, então não posso deixar. A fisioterapeuta falou que posso colocá-lo de bruços em cima de mim e hoje vou fazer o teste para ver se ele fica quietinho e se consigo dar um cochilo pelo menos, se o meu companheiro pudesse ficar aqui, talvez eu descansasse mais... Mas se Deus quiser amanhã estou em casa, espero mais um dia, fiquei a gravidez inteira sem dormir, posso esperar mais um dia.

Não tenho nada, nada mesmo para reclamar daqui. O pessoal é muito bom, muito atencioso, todo mundo, a fisioterapia, a nutrição, a enfermagem, os médicos, todos, não tenho o que falar. Estou feliz que ele vai para casa, então qualquer dor compensa." 


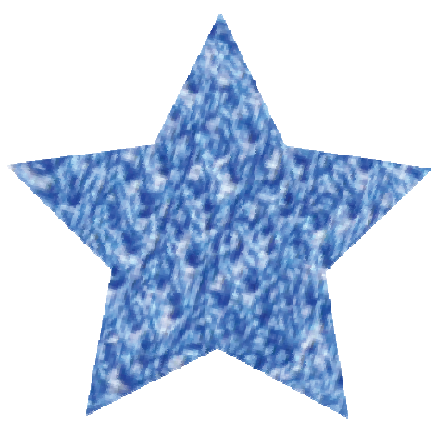

Bebê da E8 recebeu alta no dia 9 de agosto de 2013, com 11 dias de vida, com excelente evolução, com boa sucção do leite materno e com agendamento de retornos ambulatoriais quinzenais ao HCor. 
CAPÍTULO 6 AS CATEGORIAS CULTURAIS ORIUNDAS DAS NARRATIVAS

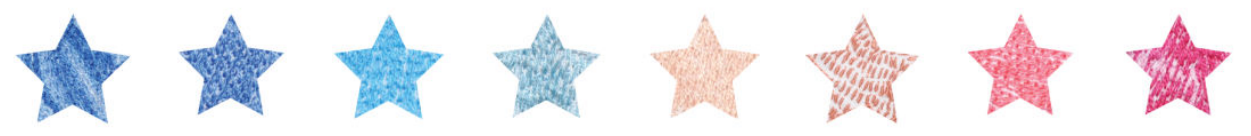



As categorias culturais são resultantes dos conceitos identificados nas narrativas das participantes. Em termos clássicos antropólogos e sociólogos referem que encontrar relações e padrões entre duas ou mais categorias conduz a totalidade da narrativa ${ }^{30}$.

A categorização de narrativas pode ser definida como uma operação que classifica elementos constitutivos de um conjunto, por diferenciação e, seguidamente, por reagrupamento segundo o gênero, com critérios previamente definidos. As categorias são rubricas ou classe, as quais reúnem um grupo de elementos (unidades de registro) sob um título genérico ${ }^{30}$.

No processo de categorização, o pesquisador tem a oportunidade de tratar os dados em todas as suas formas igualmente, podendo categorizar e agrupar os dados de forma a interpretá-los. Para tanto utiliza constantemente a análise comparativa para procurar afirmativas e índices do comportamento que ocorrem por meio do tempo e na variedade dos períodos durante o estudo ${ }^{62}$.

No processo de construção das categorias, é imperativo que as seguintes etapas sejam observadas:

$\checkmark$ Localizar dentro da experiência pessoal relatada frases chaves ou afirmações que se relacionem diretamente ao fenômeno em questão;

$\checkmark$ Interpretar os significados dessas frases como um leitor informado;

$\checkmark$ Obter a interpretação dos participantes acerca desses achados, se possível;

$\checkmark$ Investigar esses significados para verificar o que eles revelam sobre as características essenciais e recorrentes do fenômeno que está sendo estudado;

$\checkmark$ Elaborar prováveis definições ou afirmativas sobre o fenômeno com base nas características essenciais e recorrentes identificadas na etapa anterior ${ }^{56}$. 
O processo de categorização possibilita a oportunidade de tratar os dados com igualdade, permitindo, ainda, encontrar pontos de tensão e conflito e identificar os que não se aplicam ao estudo ${ }^{62}$.

Para desvendar os significados na vida dos participantes de uma investigação, o pesquisador deve submeter-se ao processo de indução, que se inicia com a imersão no texto ao processo de incubação, que permite refletir e estar alerta para as nuances do significado no contexto; à iluminação, que permite a expansão da percepção; à explicação, que inclui a descrição para que se possa captar a experiência das pessoas e, finalmente, a elaboração da síntese criativa que inclui o significado e a experiência vivida ${ }^{62}$.

Com base nas concepções acima, e, por meio da construção de diferentes categorias, foi possível explorar e compreender os significados atribuídos pelas participantes pesquisa.

Assim, nesse estudo foram elencadas 12 categorias culturais:

1 A descoberta da gravidez não planejada;

2 O enfrentamento do diagnóstico de cardiopatia congênita;

2.10 sobressalto com a notícia da cardiopatia congênita

2.2 A conscientização da gravidade da cardiopatia congênita

3 A esperança na sobrevivência do bebê - Mudança no estilo de vida;

4 O apoio de familiares e de amigos;

5 O acesso à alta complexidade: para onde ir?

6 A chegada a São Paulo: medo do desconhecido;

7 Os avanços tecnológicos $x$ maternidade;

$8 \mathrm{O}$ apego à religiosidade/espiritualidade;

9 O apoio recebido pelo terceiro setor/rede social;

100 fortalecimento do vínculo familiar frente às dificuldades advindas com a trajetória da doença;

11 A luta, o luto e as conquistas;

12 A avaliação da Unidade de Cardiologia Fetal. 


\subsection{A descoberta da gravidez não planejada}

Nesta primeira categoria foi possível constatar que a descoberta da gravidez não planejada é o início de uma trajetória de inesperados e impactantes acontecimentos para as participantes, porque a gestação é o ponto de partida para a vivência de inúmeros sentimentos e emoções aos quais as mulheres nunca foram apresentadas, os períodos de pré e pós- parto são um marco, e enfrentá-los, um desafio repleto de incertezas e pequenas vitórias ${ }^{63}$.

As falas a seguir demonstram que as participantes encontramse vivenciando a emoção da descoberta da gestação, sem contudo ter, ainda, ciência do que estava por vir.

“Esta gravidez, na verdade, não era esperada. Fiquei grávida de gêmeos há 11 anos, mas perdi os bebês e não consegui mais engravidar. Fiz tratamento para engravidar, mas não era o que Deus havia preparado para mim. Ele preparou um menininho que eu adotei e que hoje tem sete anos. Mas agora aconteceu e estou esperando uma menina."

"Este dom lindo que Deus me deu! Tantas mulheres neste Brasil com vontade de ter filho e não podem, e eu com este dom maravilhoso, nunca que vou me desfazer. Tenho quatro meninas e um menino, e agora estou esperando este menino."

O impacto causado pela gravidez não planejada dá origem a inúmeras manifestações que vão desde a euforia a sentimentos como: frustração, temor da censura, preocupação com o corpo, rejeição familiar, bem como da sociedade, do marido ou do namorado. Em relação ao contexto biopsicossocial, a necessária 
mudança de papel leva a incerteza e o medo do futuro ${ }^{64}$.

"Depois de três meses do nascimento do meu filho engravidei novamente, foi no resguardo, quando meu marido ficou sabendo que estava grávida não queria aceitar. Por isso com esse filho passei mais necessidade."

“Tínhamos planejado outra gestação para daqui um ano, mas nesse meio tempo teve a troca do anticoncepcional, estava parando a amamentação dela e engravidei".

..."Esta gravidez não foi planejada. Tenho esclerose múltipla e tomo medicamentos e acredito que me atrapalhei com o anticoncepcional".

[E8]

\subsection{O enfrentamento do diagnóstico de cardiopatia congênita}

A categoria $O$ enfrentamento do diagnóstico de cardiopatia congênita é o desvelar de um longo e árduo caminho, que será constituído de inúmeros eventos significativos. Subdivide-se em duas subcategorias:

O sobressalto com a notícia da cardiopatia congênita; A conscientização da gravidade da cardiopatia.

Essas duas subcategorias dizem respeito à surpresa e consequente conscientização da gravidade da cardiopatia do bebê. Começam a emergir sentimentos de medo, insegurança e ansiedade. 


\subsubsection{O sobressalto com a notícia da cardiopatia congênita}

A descoberta da cardiopatia dos bebês, em um primeiro momento, tende a ser minimizada pelas mães na tentativa de entender ou até negar esse acontecimento.

A negação é um mecanismo de proteção, amplamente discutida na literatura. Apresenta-se quase sempre de duas formas: a negação escolhida caracterizada por um pensamento simples "se eu ignorá-la, talvez vá embora" e a segunda forma é a negação inconsciente "realmente se olha para os fatos e não consegue percebê-los como verdadeiros"65.

..."Quando chegou a hora de fazer o ultrassom morfológico, o médico achou que havia uma alteraçãozinha no coração do nenê, ele achou que o coração estava muito grande. Fui para o ginecologista e ele me encaminhou para um médico em Campo Grande.”

"Fiz outro ultrassom e descobri o probleminha dele, aí pronto, tudo mudou, porque a minha dedicação maior agora é para ele, e tem de ser assim, só pensar nele".

"Fiz meu pré-natal em Carapicuíba. O primeiro ultrassom morfológico fiz pelo convênio no Hospital da Luz, na Vila Mariana, quando detectaram a cardiopatia na nenê. Fui encaminhada direto para o Hospital São Paulo, no Ibirapuera, perto da estação de metrô Santa Cruz, porque há estrutura para receber uma criança com este quadro. Fiz novamente o exame para ter certeza, outro exame de ecocardiograma, e confirmaram o diagnóstico." 
... "O resultado da ultrassonografia deu que o neném tinha um probleminha no coração" [...] "O nenê está com esse probleminha, vai ter que ir para São Paulo ou para Campinas para tratar e fazer um ultrassom do coraçãozinho para ver se é isso mesmo".

No livro intitulado "Mãe de UTI amor incondicional" destaca-se a fala da autora, que teve sua filha com o diagnóstico de cardiopatia congênita. “... com uma ultra-sonografia de rotina, chegou o primeiro susto: o médico responsável pelo exame me perguntou se eu já sabia que o bebê tinha um problema no coração. Assustada e descrente saí da sala dele com um cartão nas mãos: eu deveria procurar uma especialista".Eu repetia mentalmente: "Não, não é verdade, não é. ${ }^{\prime 66}$. Esse discurso vai ao encontro das falas das participantes deste estudo, ratificando a dificuldade em acreditar no diagnóstico estabelecido.

“Com 21 semanas de gestação, fiz um ultrassom morfológico e a minha médica me deu um diagnóstico não muito agradável, ela me deu um laudo de que ele poderia ter alguma doença cardíaca muito grave."

“... Fiz um ultrassom morfológico lá mesmo (Praia GrandeSP), com 20 semanas, para saber tamanho, peso, e então descobri também o problema no coração." 


\subsubsection{A conscientização da gravidade da cardiopatia congênita}

A gestante/família que se encontra na situação de ter recebido o diagnóstico de cardiopatia de seu bebê, geralmente, encontra-se em um sofrimento profundo ${ }^{67}$.

A conscientização do diagnostico faz com que as gestantes passem a fazer projeções de como será o seu futuro.

"...Fiquei bastante preocupada, porque eu havia levado a gestação normal até aquele dia e ele falou que podia ser que não fosse mais para frente, podia ser que o bebê falecesse dentro da minha barriga, antes de conseguir o socorro."

“... Foi falado que a doença que ele tinha era muito séria, e que poderia a qualquer momento falecer na minha barriga, um desespero muito grande."

A gestação por si só já é um período de crise emocional, uma vez que traz a mulher e/ou casal mudanças significativas em suas vidas. É preciso intensa disponibilidade emocional para lidar com as necessidades desse bebê desde o momento em que se tem a notícia da gravidez. Imagina quando é detectado um problema de fato $^{67}$

"...Os médicos já chegavam falando que havia o risco de ela não suportar a cirurgia". 
"O susto veio quando passei no cardiologista fetal e com o ecocardiograma fetal foi diagnosticada a cardiopatia Síndrome de Hipoplasia do Coração Esquerdo. Ele explicou a gravidade da doença e do tratamento, um lado do coração da menina não havia se desenvolvido."

“... A cardiologista do HCor falou: "vou ser sincera com você, o que o nenê tem é grave."

“...O chefe da obstetrícia do hospital, que foi bem categórico e falou com todas as letras: "Seu bebê não tem metade do coração, seu bebê vai morrer."

É fato que o medo é um sentimento penoso e difícil de lidar, somando-se a isso, o medo de perder um filho exacerba essas emoções, levando muitas vezes, a uma desestabilização emocional $^{67}$.

"Estou conversando com os médicos para tentar entender, porque a ficha ainda não caiu, é difícil de entrar na cabeça, quando falam patologia grave, é difícil de aceitar, não aceitei totalmente não".

“...Então por ela (referindo-se a prima) eu já sabia que existia esse tipo de coisa, até então na família ninguém tinha escutado falar e quando descobri a cardiopatia do meu filho fiquei maluca, falei "meu filho vai morrer"! Ai meu Deus"! 
O sofrimento diante da notícia da malformação cardíaca do bebê faz com que os pais sintam-se impotentes frente ao desejo de proteger o filho. A continuidade de sua existência está ameaçada. $E$ falar sobre isso pode significar admitir a falha ou o fracasso sentido por não gerar uma criança perfeita ${ }^{67}$.

\subsection{A esperança na sobrevivência do bebê - Mudança no estilo de vida}

Tendo se defrontado com a gravidade da doença e com o medo da perda dos bebês, as participantes passam a enfrentar o desafio da busca do tratamento, visando a sobrevivência de seus filhos. Para tanto faz-se necessário a mudança em seus estilos de vida - deixar sua cidade, sua casa, sua família...

“... Minha mãe não pôde vir comigo. Ela ficou cuidando do nosso filho, de um irmãozinho meu de seis anos". [...] "Minha sogra veio comigo, conseguimos uma ambulância para vir e viajamos 1.000 km até chegar a São Paulo"

"Fiquei com saudades dos filhos e do marido, mas em primeiro lugar estava este bebê".[..] "Foi uma emoção muito grande, mas também foi desespero deixar o lugar onde moro para vir para um lugar deste, sem ter ninguém; não vejo a hora de retornar para minha cidade."

A internação de uma criança com o diagnóstico de cardiopatia congênita para a realização de cirurgia é um momento de crise para o sistema familiar, de sentimentos ambivalentes mas também representa uma perspectiva de cura e de melhora na qualidade de vida $^{68}$. 
“...Fui ver minha filha, já estava há sete dias longe dela, nunca tínhamos ficado tanto tempo longe uma da outra, mas era por um motivo justo".

"Foi difícil, fiquei com o psicológico muito abalado, não esperava, tanto que estou praticamente afastada do serviço". [...] "no serviço eles tratavam a gravidez como se fosse nada, falavam que eu não estava doente, estava apenas grávida. Se eu faltasse e passasse um atestado no dia seguinte era piada o dia inteiro, ficava aquela coisa de dó, não tinha apoio pelo problema da nenê, estava muito difícil trabalhar. Então ficava só afastando, de atestado, trabalhava um dia me afastava mais dez e então agora vou entrar em licença em definitivo".

As falas supracitadas revelam o impacto que essa gravidez acarretou no cotidiano dessas mulheres. Todavia, a categoria a seguir demonstra que elas tiveram apoio para suportar as adversidades.

\section{4 $O$ apoio de familiares e de amigos}

O ser humano é capaz de construir uma trajetória positiva, apesar da adversidade; os familiares e os amigos que se relacionam com as participantes o fazem de maneira envolvente e significativa com muita consideração, uma vez que elas estão em um momento de vulnerabilidade de suas vidas.

“...Foi assim, ele que nunca teve responsabilidade, vivia à toa, eu era pai e mãe, e de repente uma coisa dessas, ele fica em casa tomando conta das minhas filhas, tomando conta do menino, da casa. Este bebê deu uma virada em nossas vidas”. [...] 
"Casamos, antes ele sempre dizia que não queria casar, agora está uma maravilha, saí do hospital e fomos para o cartório e casamos". Este menino nos deu muita coisa, virou a vida de cabeça para baixo, não tanto para mim, mas para o pai dele".

"O meu namorado vai assistir ao parto e ficar como meu acompanhante nos cinco dias de licença-paternidade, e eu ficarei como acompanhante dela; mas no dia do nascimento vem todo mundo, minha mãe, meu pai, meus irmãos e também a família dele e depois vamos nos revezando."

Numerosas pesquisas apontam a diferença que faz quando a mãe pode contar no ambiente familiar com a presença de um companheiro, a quem ela destina seus interesses para além dos cuidados com o filho e com cuja ajuda pode contar na complexa fase do pós-parto ${ }^{69}$.

"Não tínhamos nenhuma referência, mas a dona de um supermercado onde moro falou que eu poderia ficar na casa da filha dela, que também tinha um bebê com problema, nasceu de seis meses e ficou 78 dias na UTI. Isso foi um alívio porque o custo de vida é muito alto. Estou na casa dela há 20 dias, quis ir para a ACTC, mas não deixaram, graças a Deus são pessoas boas." 
"Voltei para a minha cidade, Pouso Alegre, fiquei lá um tempo com meu menino, meu outro filho, que estava com anemia, anemia não, pneumonia”. Ele tem um ano e sete meses. Agora está bem, passei um tempo com ele e matei a saudade. Mas estando aqui sente saudade de lá, estando lá sente saudade daqui... Sentia falta demais do bebê, aquele medo de ter deixado ele sozinho, preocupada... "A minha mãe acabou vindo, porque eu ainda estava com medo e fiquei mais uma semana com meu menino".

Um dos recursos de enfrentamento utilizados por mães de bebês cardiopatas é o apoio da família ao cuidado, sendo o espaço social onde seus membros interagem, trocam informações, apoiamse mutuamente, buscam e medeiam esforços para minimizar ou solucionar problemas ${ }^{68}$.

\subsection{O acesso à alta complexidade: para onde ir?}

A angústia pelo acesso a um serviço de alta complexidade é um dos primeiros sentimentos que as participantes demonstram ao se conscientizarem da necessidade do tratamento dos seus filhos.

Embora a regulação do acesso esteja bem estabelecida pelo SUS, a especificidade desses serviços são restritas gerando incertezas nas participantes quanto aos serviços, bem como profissionais de saúde com competência para atender às demandas da cardiopatia congênita. 
“... Em Campo Grande fiz eco e ele achou que era um caso que preocupava e que precisava de mais cuidado. [...] era um tratamento muito caro, era um tratamento de risco, havia duas equipes no Brasil que podiam cuidar do meu nenê, uma em Curitiba e outra em São Paulo."

“... Eles disseram que havia tratamento apenas em São Paulo. Então eu pensei "vou deixar meus filhos pequenininhos todos para trás e o que tiver que fazer para a vidinha deste bebê vou fazer".

“Em Mato Grosso não há tratamento, o parto seria em outro hospital, o risco não era baixo, seriam três cirurgias, a primeira mais simples e as outras duas mais complicadas". [...] "primeiro tentou o atendimento onde tínhamos parentes, porque sabia que seria demorado, mas somente temos parentes em São José do Rio Preto e lá não há tratamento". [...] "Então me encaminhou para o HCor em São Paulo e explicou o básico para eu vir sabendo o que me esperava".

Evidencia-se que é grande o desafio de garantir a oferta de serviços de média e alta complexidade a todos os Municípios brasileiros, de forma que haja adequação planejada entre a oferta de saúde ao perfil das necessidades e prioridades da população, pois estas demandas geralmente ultrapassam a esfera municipal ou microrregional, principalmente nos Municípios de pequeno e médio porte ${ }^{24}$. 
“...Fiz uma seleção na internet e mandei um e-mail para todos os hospitais: Hospital das Clínicas, Alberto Einstein, HCor, não lembro o que escrevi, lembro que perguntei o que deveria fazer. No outro dia, a equipe do HCor entrou em contato, ligou e perguntou se tinha os exames e poderia escaneá-los, pois tinha falado com o cardiologista e estava aguardando os exames para ver uma melhor data para minha consulta"

“...O médico de ultrassom ecofetal de lá (referindo-se a Praia Grande) também viu a patologia e ele mesmo me indicou a vir para São Paulo. Fiquei perdida, não sabia como vir, mas tive a sorte de ter uma prima que trabalha no Hospital do Coração e que me ajudou a chegar aqui."

Estudos demonstram que o acesso ao serviço é destacado como definidor da qualidade da atenção à saúde materno infantil ${ }^{70}$.

\subsection{A chegada a São Paulo: medo do desconhecido}

A chegada a São Paulo para algumas das participantes do estudo significou o enfrentamento do novo, a descoberta da metrópole antes vista apenas pela televisão, agora a mudança do viver é inevitável, afastar-se da sua cidade, da sua família, exige uma superação, uma transformação no modo de encarar a própria vida.

A cidade de São Paulo, para essas mulheres, torna-se paradoxal, pois é, a um só tempo, atemorizante pelo impacto provocado pelos seus excessos e fonte possibilitadora da realização do desejo maior- a cura do filho. O momento seguinte pressupõe a sua inserção nesta nova ordem social, exigindo um processo de 
reconstrução não apenas do seu cotidiano, outrossim de sua constituição, e da sua subjetividade ${ }^{71}$.

“... A gente não conhecia nada aqui em São Paulo, não tinha família, não sabia de nada, daí fiquei preocupada. Como vou fazer lá, não conheço nada, vou chegar lá e vou ficar perdida, eu pensava. E todo mundo me falava que São Paulo era uma cidade perigosa, que ninguém ia me ajudar, que ninguém me conhecia.”

“...Foi uma emoção muito grande, mas também foi desespero deixar o lugar onde moro para vir para um lugar deste, sem ter ninguém; não vejo a hora de retornar para minha cidade." [...] Cheguei aqui sem noção de nada, o pessoal falava, "mãe, tu não imagina como é São Paulo, é muita gente, é muita gente que não é brincadeira".

“...No início me assustei muito, porque sou de uma cidade pequena onde o trânsito é calmo e as pessoas conversam. Aqui não, ninguém conversa com ninguém. É tudo muito louco, o trânsito, gente o tempo inteiro, não se vê essa cidade num final de semana com poucas pessoas, ônibus lotado, metrô lotado, muito diferente de onde moro. [..] Então os primeiros dias me impactaram, tinha medo de sair, de andar, até quando vinha às 6 horas da manhã (em meia hora estava aqui), vinha andando segurando a bolsa, a mão até doía de tanto que segurava por medo, porque a gente mora fora e ouve muito coisa de São Paulo. Hoje ando mais tranquila, ainda cuido da bolsa, mas não vejo a hora de ir embora." 
... "Não conhecia São Paulo, é a primeira vez que vim para cá, nossa, é grandão, nunca imaginei que iria ver assim de perto, gostei, só via pela TV".

Chegar a São Paulo em busca do tratamento dos seus filhos cardiopatas significa falar em mudança, deslocamento e, consequentemente, afastamento do familiar, do que era próximo e conhecido, como: valores, hábitos, costumes e visão de mundo. Nesse sentido, exige flexibilidade, adaptação, aquisição de novos conhecimentos e transformação ${ }^{71}$.

\subsection{Os avanços da tecnológicos versus gestação de alto risco}

A gestação de alto risco requer assistência mais especializada nos níveis secundário e terciário, com equipe de saúde e tecnologias sofisticadas. A vivência da gestação de alto risco caracteriza-se por um processo extremamente complexo, dinâmico, subjetivo, diversificado, individual e social. É uma experiência única, que se estende ao companheiro, à família e à sociedade, não é apenas um evento biológico, podendo gerar situações de crise que envolvem transformações fisiológicas, psicológicas, sociais, econômicas, culturais, espirituais ${ }^{72}$.

Referente à neonatologia moderna, por meio da sofisticação de técnicas e equipamentos que passou-se a tornar viável a sobrevida de bebês prematuros e/ou com agravos à saúde.

Embora necessário, o uso da tecnologia deve considerar os potenciais riscos e benefícios. Nesse contexto, a tecnologia não é boa nem ruim, mas a aplicação humana é que determina a sua natureza. Assim, o limite entre a ciência e a tecnologia não é bem 
definido, perdendo a sua importância, se não estiver vinculado aos valores éticos ${ }^{73}$, conforme discutimos no capítulo 1.

"Quando chegou a hora de fazer o ultrassom morfológico, o médico achou que havia uma alteraçãozinha no coração do nenê, ele achou que o coração estava muito grande."

“... O primeiro exame de ultrassom não acusou nada. Depois de 15 dias fui a João Pessoa, fiz outro ultrassom e descobri" [...]”A primeira vez que fiquei sabendo do problema do bebê foi desespero..." [...] "Quando marquei a eco, estavam os cardiologistas de João Pessoa e a médica do Recife. Eles conversavam e tiravam as dúvidas, falavam bem baixinho para eu não ouvir, mas a cardiologista do Recife falava alto e eu entendia”...

“...Queria ter uma menina, mas se viesse menino, tudo bem. No primeiro ultrassom a nenê estava muito pequena, mas nos demais pude ver que era uma menina mesmo, então não tive mais dúvida, quando é o que a gente quer, melhor ainda."

“...Comecei a fazer o pré-natal, com cinco meses fiz o ultrassom morfológico e descobri que era uma menina”...

A ultra-sonografia leva ao limite máximo a possibilidade de vigilância na gestação, na medida em que as próprias gestantes passam ativamente a solicitar poderem 'ver' os seus fetos. A tecnologia de ultrassom pode ser compreendida como personificação do poder disciplinar, normatizador, subjetivante e, portanto, constitutivo de novos sujeitos: gestantes e fetos. 
"A tecnologia da parturição muda de "ganhar o controle sobre o parto" para "monitoramento e vigilância"21.

"[...] Então a minha mãe pegou o ultrassom e a gente viu tudo certinho e foi assim que aconteceu".

"Fizeram um exame que tira sangue do cordão umbilical e um ecocardiograma."

“Descobri quando fiz um ultrassom morfológico lá mesmo, com 20 semanas, para saber tamanho, peso..."

"Faço pré-natal pelo convênio, pelo posto e agora ela me encaminhou para cá, fiz tanto ultrassom que quando ele nascer já vai sair fazendo pose para foto". (risos)

Muitos estudos demonstram que o exame da ultrassonografia vem sendo requisitado pelos profissionais de saúde e pelas gestantes de modo excessivo, levando ao uso abusivo. O desejo de ver o feto ganha força na busca de readquirir uma tranquilidade constante. Nesse sentido, observamos que, as mulheres passaram a depender, emocionalmente, da tecnologia de ultrassom para sentirem-se confiantes e próximas de seus bebês ${ }^{73}$.

No que se refere à medicina fetal, novos questionamentos surgiram: o primeiro deles coloca o feto no lugar de paciente a ser tratado, promovendo uma reconfiguração sobre o corpo da mulher e a gravidez; e o segundo ponto de análise é a suposta independência do feto ao corpo da mãe, levando a diversos dilemas éticos. Essa conjunção tem como pressuposto a sobreposição da vida do feto 
sobre a vida, saúde e vontade da mulher, que fica em segundo plano frente a gravidez ${ }^{73}$.

Tal fato é analisado como uma influência da inserção desmedida da ultrassonografia no pré-natal $^{73}$.

\section{8 $O$ apego à religiosidade/espiritualidade}

A espiritualidade ao ser definida como uma propensão humana a buscar o significado para a vida, por meio de conceitos que transcendem o tangível, remete a um sentido de conexão com algo maior que si próprio, que pode ou não incluir uma participação religiosa formal ${ }^{74}$.

"O que define o sagrado é o fato de ser acrescentado ao real" [...] Neste espaço "as energias vitais estão superexcitadas, as paixões mais vivas as sensações mais fortes; existem mesmo algumas que só se produzem senão neste momento. $O$ homem não se reconhece; sente-se como que transformado e, por conseguinte, transforma o meio que rodeia. Para explicar-se as impressões muito particulares que experimenta, ele atribui as coisas com as quais está em relação, poderes excepcionais, virtudes que não possuem os objetos da experiência vulgar"39.

Nesta categoria as participantes expressam sua espiritualidade, atribuindo muitas vezes à vontade de Deus o desfecho do tratamento dos seus bebês. 
..."Confio muito em Deus, e tinha certeza de que Ele estava do meu lado, estava comigo e pedi muito: Senhor, coloca tuas mãos em cada pessoa que está me atendendo, cada pessoa que está cuidando da bebê, guia a vida de cada um, as mãos, a inteligência, a mente de cada pessoa, para que corra tudo bem [...] Sabe a gente não pode desistir, tem de entregar na mão de Deus, porque se Ele preparou tudo é para a gente."

[...] Queria muito que ele tivesse vindo para cá vivo (referindose a Rio Tinto- Paraíba), mas foi a vontade de Deus e foi feita a Sua vontade, mas agradeço ter ficado esses trinta dias com meu filho, aproveitei muito, "esse tempo valeu por uma eternidade."

“... Sou católica e acredito que a minha religião é à base de tudo. Lógico que não vou deixar de estar aqui no hospital, mas a religião ajuda muito, para mim pelo menos, me dá apoio.”

"Não vou dizer que tenho uma religião porque estaria mentindo, frequento a igreja evangélica, não sou muito de igreja católica, mas não sou assídua. Meu pai é pastor da Igreja Tradicional da Graça, então eu vou. Mas a fé é muita".

A importância da religião na interpretação e tratamento da doença tem sido amplamente reconhecida na antropologia. Vários estudos sobre o tema observam que os sistemas religiosos de cura oferecem uma interpretação da doença que a insere no contexto sociocultural mais amplo dos indivíduos ${ }^{38}$. 
“... E todas nós sabemos que agora está na mão de Deus, é o que a minha mãe conversa sempre comigo, entrega nas mãos de Deus, porque a gente não pode fazer nada. Sou evangélica, a única solução é orar, pedir para Deus que ele tenha cura". "Que venha saudável e forte."

[...] Com o coração na mão me despedi do meu filho, pedi muito a Deus e aos meus Orixás que aquilo não passasse de uma sensação ruim [...] fui rezando, pedindo para que ele ficasse bem, mas quando eu cheguei dei de cara com os aparelhos já desligados e alguns "mentores" ao lado do corpo físico dele..."

“... Tenho que levá-lo em quatro igrejas para apresentá-lo de tanta oração que foi feita. Graças a Deus, deu tudo certo, a cirurgia, o pós-operatório, ele ficou pouco tempo na UTI, já está aqui no quarto e já vai embora, então é só alegria."

Frente a essas falas, percebemos o quanto a religião diante da situação de doença de um filho é um recurso de enfrentamento dessa vivência.

\subsection{O apoio recebido pelo terceiro setor/ rede Social}

Esta categoria é percebida pelas participantes como essencial devido ao fato de serem acolhidas, junto com suas famílias, por ocasião do tratamento cardíaco em São Paulo. Serem acolhidas e poder contar com a solidariedade e a organização do terceiro setor foram essenciais nesta etapa. 
Nas narrativas observamos a citação de duas instituições, que marcam a vida dessas mulheres, pois tais instituições mantêm-se no foco da atenção às famílias de crianças cardiopatas. São elas: ACTC e ONG Pequenos Corações, descritas no capítulo 4.

As mães que são acolhidas na ACTC incorporam a palavra "casa", sendo comum ouvir "a casa está cheia", a "casa está vazia", a "casa está triste". A casa pulsa a vida e a morte, a dor e a esperança. Ela emudece, é alegre, reflete os sentimentos, o estado de espírito. A solidariedade, o compartilhar de coração para coração, tudo isso reequilibra as emoções e sentimentos dessas mulheres, que passam por experiências tão similares ${ }^{71}$.

“... O pessoal da ONG Pequenos Corações ligou para mim perguntando como eu estava, contei que estava arrasada, queria levar meu bebê comigo e a funerária não arcaria com as despesas e não sabia o que fazer [...] Então a moça da ONG Pequenos Corações ligou para outra funerária de Carapicuíba e com menos de cinco minutos me ligou e disse para não me preocupar que eu voltaria com meu filho para a Paraíba. Foi um alívio muito grande."

“... Vou tentar vir para a ONG Pequenos Corações, perto do hospital, porque é um gasto muito alto vir todos os dias de ônibus e metrô. Também vou ficar mais tempo com a minha filha por não precisar sair mais cedo [...] Na ONG fica tudo mais fácil e também estão outras mães."

“... Na ACTC têm pessoas com sotaques diferentes, cada uma veio de uma cidade, falam engraçado, gosto de falar com elas, fico rindo dos sotaques" [...] "Depois da nossa última entrevista voltei para a ACTC, onde sempre havia alguma atividade para fazer e é onde fico com outras mães que têm os filhos com outros problemas 
também". [...] "Lá é legal, a gente tem amizade, sempre saindo e chegando gente. Quando voltei várias mães já tinham ido embora, depois de eu ter feito muitas amizades."

As participantes diante da situação desestabilizadora que vivem, provocada pelo deslocamento geográfico, pela possibilidade de perda e pelas dificuldades financeiras, encontram na casa da ACTC apoio e, momentaneamente, um polo de organização do caos em que elas se encontram ${ }^{71}$.

“... Fui para a ACTC, onde fiquei hospedada o tempo em que ele ficou internado. Fui muito bem acolhida pelas mães, estava recém-operada, todas foram muito prestativas. Conheci uma senhora que foi muito especial naquele momento, que estava lá acompanhando sua filha, como ela disse estávamos todas no mesmo barco, todas acompanhando nossos filhos cardiopatas."

[E6]

“... Na verdade vou ficar instalada na ONG Pequenos Corações perto do hospital, que ainda vou conhecer. Para mim, ficar subindo e descendo já está cansativo" (referindo ao fato de vir da Baixada Santista).[...]"Estou ficando na casa de apoio, a ACTC. Nos primeiros dias foi difícil porque não conhecia ninguém, até acostumar com a casa... E perceber que estava longe da minha família, foi difícil. Mas agora acostumei e até brinco que a ACTC é a minha segunda "casa". "Quando vou para a minha cidade falo "tchau, gente, estou indo para a minha segunda casa". 


\subsection{0 fortalecimento do vínculo familiar frente as dificuldade advindas com a trajetória da doença}

Nas narrativas e na observação participante constatamos que todas as participantes desta pesquisa contavam com o apoio de seus companheiros, compartilhando angústias e preocupações e também, com seus núcleos familiares e rede amigos envolvidos no cuidado ao binômio mãe e filho.

"O apoio da família é grande, todos preocupados, vindo vê-la; sempre que preciso de algo, sou ajudada em tudo. Estão todos torcendo para ela ir para casa logo".

“...O meu marido assistiu ao parto e me deixou mais tranquila, ficou o tempo todo segurando a minha mão, conversando comigo, pois é meio traumático porque nunca se sabe sobre o parto, minha mãe sempre diz "quando a gente engravida é um pé no chão e o outro na cova". [...] "O meu filho veio junto com o pai quando ela nasceu, ficaram dez dias, me ajudaram muito. Quando foram embora, o meu leite até secou, por mais que estivesse com a minha sogra, me senti só. "Agora à distância conversamos todos os dias, mas não é a mesma coisa."

A família é considerada parte essencial inquestionável para o cuidado humano e sua atuação funciona como fonte de acolhimento determinante do tipo de vivência dos pais frente a doenças de seus filhos ${ }^{69}$. 
“... O meu marido sempre me acompanhou nas consultas. Na época trabalhava como mestre de obras, mas mesmo que se atrasasse, chegava a tempo para me acompanhar, estava presente em todos os momentos... Mas me mantive muito calma, estava falando com meu marido e minha família o tempo todo pelo telefone".

“... A família está dando apoio, minha mãe, meu pai, meu marido, eles dão bastante apoio para eu tentar ficar calma. Sou muito ansiosa, quando lembro começo a chorar e desanimo, fico triste e eles tentam todos me colocar para cima". [...] "O meu marido é mais reservado, não é como eu que chora na frente de todo mundo, é de ficar no cantinho dele, chora sozinho, primeiro filho dele também, está preocupado".

“... O meu companheiro conseguiu entrar para vê-lo junto com meu pai e as minhas irmãs, conseguiram vê-lo sem aparelho nenhum, sem oxigênio, sem nada, demorou ainda para colocar e quando eu vi, ele já estava com oxigênio, mas perfeito, um bebê perfeito".

De acordo com as falas percebemos que o vínculo é imprescindível para que os casais encontrem apoio mútuo como ressalta a citação a seguir.

Apertávamos as mãos um do outro- era preciso sentir, sem dizer, que estávamos juntos. Numa linguagem antiga, nossas mãos diziam por nós que tudo daria certo, que uma ia apoiar a outra e, juntas, elas se amparariam ${ }^{66}$. 


\subsection{A luta, o luto e as conquistas}

Reconhecidamente destacam-se quatro modos de enfrentamento da doença, com diferentes graus de adaptação: o espírito de luta, em que ocorre uma busca intensa por diversos tipos de tratamento; o estoicismo, no qual a pessoa aceita e suporta tudo com resignação e conformismo; a negação e o evitamento do contato com a doença e com a desesperança, em que a pessoa entrega-se ao desespero e desiste de lutar, na maioria das vezes, apressando a morte ${ }^{75}$

Diante do sofrimento vivido, especialmente, no período de internação das crianças na Unidade de Terapia Intensiva Neonatal, os pais tornaram-se capazes de reorganizar suas vidas, por meio do crescimento pessoal e da luta constante empregada no cuidado do filho ${ }^{76}$

As narrativas abaixo mostram os diferentes destinos dos bebês deste estudo.

“... Quando acabou o procedimento a doutora me disse que estava tudo bem, que a bebê estava bem, que era para aguardar amanhã, para ver como ela ia reagir, como ela ia se recuperar. $E$ quando eu vim para o quarto, acho que às 5 horas da manhã, ela já se mexeu dentro da minha barriga e eu fiquei bem mais tranquila."

[E1]

“... Quando cheguei, sofri muito, chorava pelos cantos quando via as coisinhas dele, as fotos, as roupinhas... Mas o tempo foi passando, foi diminuindo, porque passar não passa nunca, mas estou indo". 
O luto assemelha-se a uma ferida física mais do que qualquer outra doença. Como no caso do machucado físico, o "ferimento" aos poucos "cicatriza". Em algumas situações, a cura é mais lenta ou um ou outro ferimento se abre novamente ${ }^{75}$.

“... Tive muitas surpresas, pois acreditava que era só fazer a cirurgia e ir para casa, não sabia de toda essa recuperação, todo este procedimento, mas está muito bom. Ela já abre os olhos, entende tudo, eu a deito ali e ela entende, mas dá dó, o olho dela enche de lágrima, parece que quer chorar, mas é muito bom ficar ao lado dela, nem tem como explicar."

“... Difícil escutar que a cirurgia deu certo, mas houve intercorrências e foi preciso fazer transfusão de sangue, pois a pressão dela baixou muito. Houve essas dificuldades, a despedida, eu me despedi antes de a nenê entrar na sala de cirurgia, a angústia dessas três horas e depois esperar mais duas horas para vê-la, e então encontrá-la intubada, sedada, toda molinha, dá uma sensação ruim, mas está aí, está lutando!”

Tentamos nos defender de vários modos contra o medo da morte e contra a incapacidade de prevê-la, dominá-la e evitá-la ${ }^{75}$. A morte está presente desde o início do desenvolvimento humano. Ela é experienciada e experimentada a partir do nascimento até os últimos dias, porém apesar de "certa", em algum momento da vida, ela parece não fazer parte de um processo natural, principalmente, quando refere-se a morte do próprio filho ${ }^{75}$. 
“... Perguntei se o coração dele tinha cura e ela (referindo-se a médica) falou que não, só não chorei porque senti muita vergonha, mas bateu uma tristeza, fiquei angustiada. Falaram que não tinha cura, mas tinha tratamento para mantê-lo vivo, então fiquei mais tranquila. Graças a Deus, pelo menos ele está firme e forte e os boletins médicos sempre falam que está tudo bem com os procedimentos."

“... Me acabei em lágrimas, achei que tudo estava perdido, meu coração sangrou. Não esperava ver meu filho daquele jeito, criei uma fantasia na minha cabeça, o cirurgião foi tão confiante e positivo, ele ficou tão bem antes da cirurgia, coisa de mãe, me deu choque, uma sensação terrível e a partir daquele momento meu alarme de mãe começou a falar mais alto."

“... Até pouco tempo atrás estava muito pessimista, completamente pessimista, pensava "meu filho não vai viver, tenho que me preparar, já enterrei um e vou ter que enterrar outro”... Agora não! Agora já estou um pouquinho mais otimista, com medo, mas otimista.

As participantes desta pesquisa demonstraram, ainda, a capacidade em enfrentar e responder de forma positiva às experiências sendo que ao se defrontarem com as situações de risco, passaram a ter esperança nos desafios que se apresentavam. 


\subsection{A avaliação da Unidade de Cardiologia Fetal}

As participantes do estudo consideram-se privilegiadas por conseguirem o acesso à Unidade de Cardiologia Fetal. Alegaram terem se surpreendido com o fato de terem sido tão bem atendidas em um projeto de filantropia e referiam igualdade de tratamento com os demais pacientes.

“... Eles são muito dedicados e muito cuidadosos [...] A equipe atende a gente muito bem, não há diferença entre ela, que é da filantropia, e particular ou pelo plano, todo mundo é igual, passou aquela portinha ali (aponta a porta da UTI) é todo mundo igual. A gente vê criança que ficou na UTI muito tempo e que depois volta para visitar a equipe e a gente vê a felicidade dos médicos e dos enfermeiros, e sai todo mundo lá da UTI para ir à recepção para ver as crianças que eles cuidaram".

..."Da equipe do HCor não tenho nada para me queixar, meu marido tem a mesma opinião, ele passou quinze dias no HCor, o atendimento foi muito bom, a equipe é excelente".

“... A psicóloga me ajuda bastante. Antes era outra, mas como no dia do parto era carnaval e ela estava viajando fiquei com esta psicóloga, que é muito legal, ela é uma amiga, conversamos, ela me explica, eu entendo. É muito bom esse procedimento, pensei que somente a criança recebia o tratamento, mas nós também somos tratados". [...] "Acho que não tenho nada de negativo para falar do serviço, não tenho mesmo, agora meu desejo é levá-la para casa.” 
... "Estou sendo bem tratada aqui, as enfermeiras são excelentes, não têm aquele padrão frio. Elas têm uma preocupação com a mãe também, procuram nos tranquilizar. [...] "Não há uma enfermeira que possa falar que não gostei. Se reclamo de alguma coisa, logo agradeço, é uma situação complicada e o tratamento que a minha filha está recebendo é muito bom. As mães estão sempre observando e se há alguma alteração as enfermeiras correm para verificar, há um interesse de todas de realmente cuidar e de fazer o melhor."

Estudos demonstram que ações de acolhimento e vínculo são fundamentais para a qualidade e a continuidade no cuidado ${ }^{77}$.

... "Mas está bom porque estou sendo muito bem atendida, aqui está acontecendo tudo do jeito que vocês falaram mesmo."

"Fui muito bem amparada pela equipe do HCor, as técnicas foram maravilhosas, a psicóloga do hospital foi maravilhosa, apesar de depois da partida do bebê não ter realizado nenhum contato comigo. [...] "Queria ter saído com meu filho daí e espero com a minha experiência poder ajudar outras mães”. 
“... Da equipe não tenho o que reclamar, a minha filha tem mais tratamento "vip" do que eu quando era pequena. Penteiam o cabelinho, colocam uma presilhinha, é xampu bom, hidratante no corpo, manteiga de cacau, tudo assim, chiquisinho para ela. Eles têm um cuidado, um amor, pelo menos todo enfermeiro ou enfermeira que conheci, que cuidaram da bebê." [...] "Nem falo que é um hospital, até brinco que é um hotel, você não se sente num hospital, graças a Deus, a minha filha está em um lugar ótimo."

“... Foi muito legal, a recepção do pessoal do hospital, a hospitalidade da equipe da enfermagem [...] Não tenho nada, nada mesmo para reclamar daqui. O pessoal é muito bom, muito atencioso, todo mundo, a fisioterapia, a nutrição, a enfermagem, os médicos, todos, não tenho o que falar. Estou feliz que ele vai para casa, então qualquer dor compensa."

As falas mostram que os processos interpessoais, atitude respeitosa, atenção, apoio emocional, estilo de interação acessível e tempo dedicado estiveram presentes. Um tema recorrente tecido ao longo dos dados reflete a importância de uma relação significativa entre uma mulher e o prestador de cuidados, que se caracteriza pela confiança $^{78}$.

Entretanto, surgiram pontos que merecem atenção tais como: o local onde o parto seria realizado. As participantes demonstraram, claramente, preocupação com o fato da possibilidade de ocorrência do parto em outra instituição; dúvidas sobre a obrigatoriedade do parto cesáreo; demora no pós-parto em conhecer o recém-nascido, impossibilitando o contato precoce; dificuldades com a amamentação; necessidade de adequação dos fluxos de atendimento da equipe multidisciplinar e dos agendamentos dos retornos em nível ambulatorial. 
“... Como as médicas falaram, se eu entrasse em trabalho de parto antes da data marcada no HCor era para ir para o Hospital das Clínicas. Era final de semana de carnaval, foi de domingo para segunda. Falei para as médicas que o nenê tinha um problema no coração e que não podia ser parto normal, que era difícil o caso dele. Falaram que não tinha problema, que eu que tinha que fazer força. Como ele não queria descer de jeito nenhum acabou fazendo cesariana" [...] "foi ruim, porque queria ter ganhado ele aqui, mas ele não esperou. Estava tudo combinado, na quarta-feira era para vir cedo, já tinha vindo conhecer o hospital, até a psicóloga iria me acompanhar..."

“...Apesar de os protocolos não terem nenhuma confirmação de que os bebês com hipoplasias não podem nascer de parto normal, é conveniente que nasçam de cesariana. [...] Se o meu bebê resolver nascer hoje vou para o HC (Hospital das Clínicas), vou ficar na fila, não têm prontuário, então é de praxe que tentem fazer parto normal...

[...] Meu contato com ele nesse primeiro momento não foi bom porque eu estava recém-operada, para vê-lo precisava do acompanhamento de uma enfermeira, o que dificultava um pouco algumas vezes pela demora".

"Na quinta feira à noite, bem tarde, fui avisada que a cirurgia do meu bebê seria na sexta-feira, dia 3, pela manhã. Achei um pouco falho isto, pois o contato com a equipe foi muito próximo... ficamos todos apreensivos." [...] "As enfermeiras o batizaram durante à tarde, o que me deixou muito revoltada, porque se ele já apresentava maus sintomas durante o dia eu deveria ter sido comunicada." 
“... À noite fui conhecer a minha filha, não via a hora, o parto foi de manhã e só fui vê-la à noite por causa da cesariana. Ela nasceu na quarta-feira e na manhã seguinte já fez a cirurgia.” [...]

“... Ela nasceu às 9h30 e fui conhecê-la por volta das 21 horas, porque precisava esperar a anestesia passar e ter uma pessoa me acompanhando. Na hora que nasceu me deixaram dar um cheirinho, mas olhar mesmo, tocar, só à noite depois que passou a anestesia e que conseguia ficar em pé.

"O retorno no HCor seria no dia 8 de janeiro de 2013, mas ligaram e remarcaram primeiro para o dia 15 de janeiro, e depois mudaram de novo para o dia 22. [...] "fazia 12 dias que a gente estava em Carapicuíba. E eu estava esperando este retorno no HCor para eu saber quando poderia voltar para Paraíba." [...] "Tentei ligar para o HCor, mas não consegui.

A avaliação dos serviços de saúde, na pesquisa qualitativa, valoriza as relações interpessoais e proporciona expandir o conceito, pois ao escutar as participantes temos a oportunidade de avaliar o serviço não meramente na interpretação objetiva de satisfação dos usuários e sim interpretando em uma visão mais ampla, proporcionada pela escuta e pela observação atenta daqueles que assistimos.

Dessa forma, acreditamos que a escuta dessas participantes permitiram o alcance dessa premissa, a fim de proporcionar a reorganização dos processos no cenário deste estudo que serão apresentadas no capítulo 8. 



\section{CAPÍTULO 7}

ANÁLISE INTERPRETATIVA À LUZ

REFERENCIAL TEÓRICO

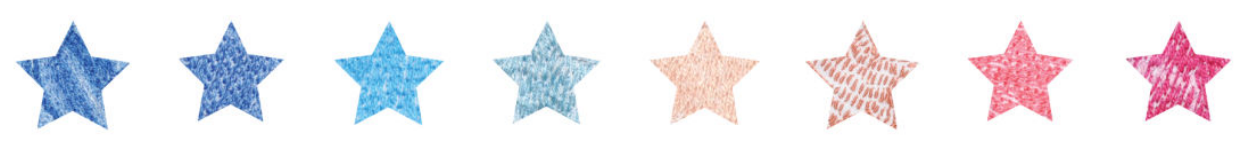



O referencial teórico adotado para a análise interpretativa dos achados desta investigação foi o referente à Trajetória da Doença Crônica proposto por Michael Bury, no intuito de evidenciar e compreender a experiência das participantes - mães de crianças com diagnóstico de cardiopatia congênita.

De acordo com esse referencial, embora a doença possa acontecer em qualquer fase da vida, a expectativa da sociedade é de uma vida longa e saudável. Dessa maneira, quando há o surgimento da doença há, também, o rompimento da estrutura social e cultural do indivíduo, expondo-o, consequentemente, às ameaças a sua auto-identidade ${ }^{79}$.

Nesse pressuposto, três aspectos da resposta à experiência da doença crônica podem ser distinguidos. O primeiro seria a ruptura biográfica, causada pela enfermidade e as tentativas iniciais em lidar com incerteza que ela traz; o segundo é o impacto do tratamento na vida diária e no cuidado à saúde; e o terceiro é a adaptação e o manejo da doença, como os indivíduos e a família respondem a vivência da doença e tentam reconstruir suas vidas ${ }^{80}$.

Em relação a ruptura de pressuposições e comportamentos dados como certos; a quebra das fronteiras do senso comum, que sugere uma abordagem "disruptiva" à doença. Esse estágio caracterizado pelo questionamento "O que está acontecendo"?, envolve atenção aos estados corporais que nem sempre são trazidos à consciência e decisões sobre procurar ajuda. Em segundo lugar, há rupturas mais profundas nos sistemas explanatórios que são normalmente usados pelas pessoas, de tal maneira que uma revisão fundamental da biografia e do autoconceito da pessoa está envolvida. Em terceiro lugar, há a reação à ruptura envolvendo a mobilização de recursos, no enfrentamento de uma situação alterada $^{81}$.

A Figura 2 esquematiza a Trajetória da Doença Crônica proposta por Michael Bury. 
Figura 2 - Esquema demonstrativo da trajetória da doença crônica proposta por Michael Bury (1997).

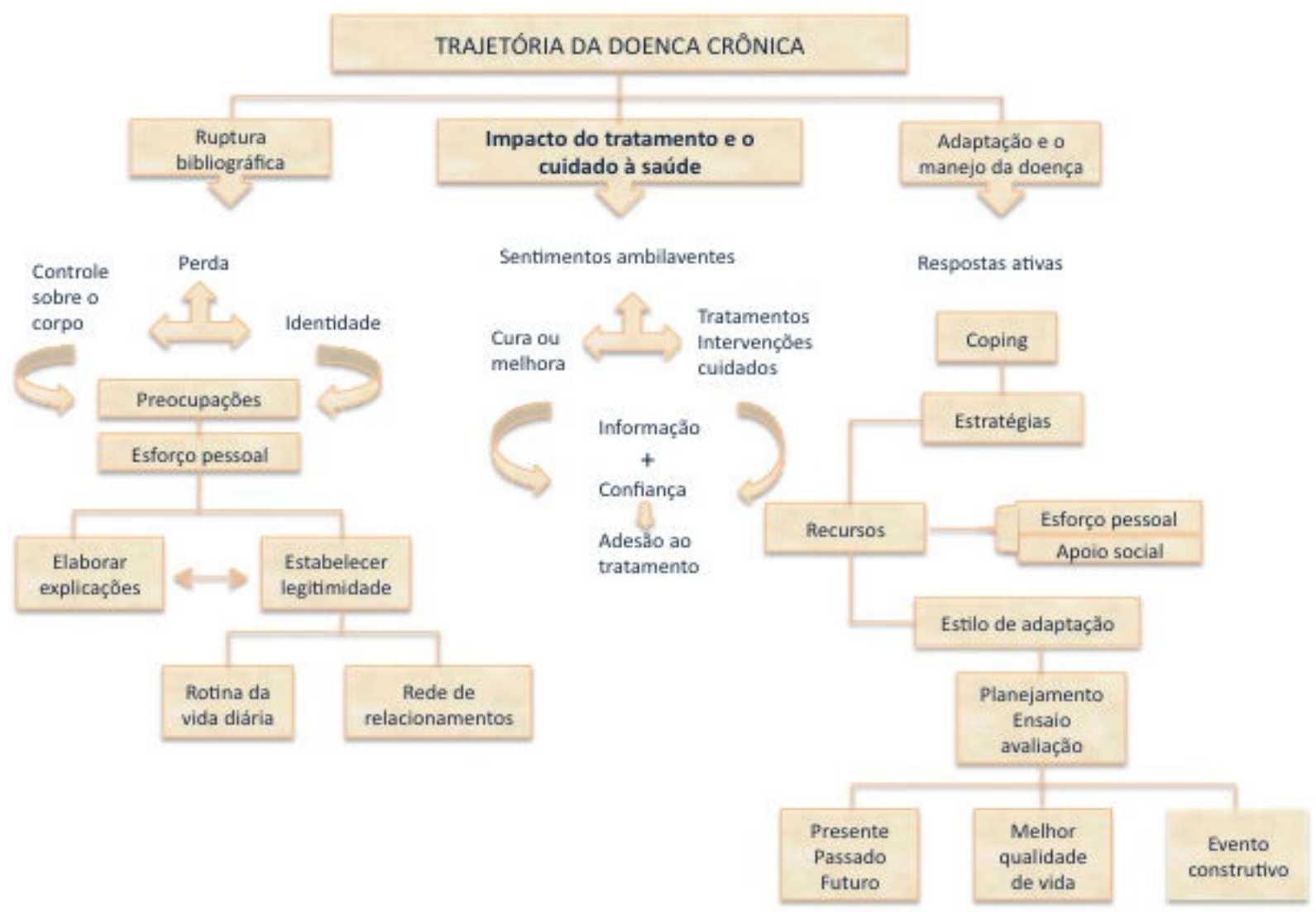

Fonte: Bury M. Health and IIIness in a changing society.New York: 1997.

A Ruptura biográfica é caracterizada pela perda potencial da identidade e pela perda do controle sobre o corpo resultantes das alterações corporais, do aparecimento dos sintomas e do estabelecimento do diagnóstico, há uma quebra das crenças e comportamentos cotidianos. Esse estágio, traduzido pelas perguntas O que esta acontecendo? Porque eu? Porque agora? Envolve atenção para aspectos não conscientes e decisões sobre a procura de ajuda $^{79}$. Neste estudo, as participantes deparam-se com esse estágio quando da descoberta da gravidez e, sobretudo, com o diagnóstico da cardiopatia congênita. 
“Em Campo Grande fiz eco e ele achou que era um caso que preocupava e que precisava de mais cuidado. Pediu quatro semanas para conseguir um encaminhamento para algum lugar onde houvesse recurso, porque era um tratamento muito caro, era um tratamento de risco".

"Com três meses e duas semanas de gestação, descobri que o meu bebê tinha um problema no coração. Foi uma notícia muito ruim. Minhas criancinhas são sadias, quando descobri esta gravidez sofri muito no início, foi uma surpresa muito grande, principalmente para o pai. Os médicos falaram que era uma doença muito grave e que o nenê não teria chance de sobreviver".

"O susto veio quando passei no cardiologista fetal e com o ecocardiograma fetal foi diagnosticada a cardiopatia SHCE. Ele explicou a gravidade da doença e do tratamento: um lado do coração da menina não havia se desenvolvido. Em Mato Grosso não há tratamento, o parto seria em outro hospital, o risco não era baixo, seriam três cirurgias, a primeira mais simples e as outras duas mais complicadas".

Quando a condição de risco é diagnosticada durante a gestação a grávida experimenta, então, todas as reações associadas à vivência do luto, pela "morte da gravidez idealizada". Surgem sentimentos de culpa, raiva, censura. Sentimentos de incerteza, de não saber o que está acontecendo e sentimentos de impotência emergem nesse momento da descoberta ${ }^{68}$. 
"No início pensava "meu Deus, se o pecado foi meu porque a minha filha vai pagar", dizem que os filhos sofrem por causa dos pais e eu pensava dessa forma. Depois fui pensando, tanta mulher grávida que entrega o filho para os outros, porque isso aconteceu com a minha filha? Sou uma mãe ruim? Será que não iria cuidar bem?"

No caso de patologias associadas à gestação esse fator exacerba-se, uma vez que já não são somente as alterações fisiológicas do ciclo gravídico-puerperal que necessitam de atenção. Trata-se, agora, de dar conta de uma patologia complexa, que necessitará, na maioria das vezes, de um longo e invasivo tratamento, o qual nem sempre garantirá a sobrevida desse filho ${ }^{68}$.

A necessidade de após o nascimento dos bebês da hospitalização pode configurar-se como uma experiência potencialmente traumática, porque afasta a criança das mães, do ambiente familiar e promove um confronto com a dor, a limitação física e a passividade, aflorando sentimentos de culpa, punição e medo da morte ${ }^{68}$.

Na segunda fase da Trajetória da Doença Crônica identificada como o Impacto do tratamento e o cuidado à saúde, os serviços de saúde surgem como parte dos recursos disponíveis para se enfrentar os efeitos perturbadores da doença e podendo proporcionar segurança às pessoas, mas também momentos de apreensão e ansiedade, uma vez que elas estão chegando até eles com sentimentos ambivalentes. Se, por um lado, vislumbram a possibilidade de cura ou melhora, por outro, tomam consciência da necessidade da convivência com tratamentos, intervenções e cuidados que, geralmente, são obrigatórios, de longa duração e, em alguns casos, dolorosos ${ }^{79}$. 
"A médica do HCor me explicou que ela tem SHCE, que ela já fez a valvuloplastia, ela fez outro procedimento chamado cateterismo e outro que eu não lembro o nome. E na semana passada ela colocou um stent".

Com o passar do tempo à pessoa começa a ter um maior conhecimento sobre a sua doença, sobre a forma de tratamento e inicia um processo de compreensão das informações recebidas dos profissionais, de outros pacientes e dos meios de comunicação. Dessa maneira, tornam-se mais confiantes e estabelecem critérios para avaliar a evolução do tratamento adotado ${ }^{80}$.

“... A recuperação foi boa, mas o stent que colocaram não deu certo. O canal do coração dela é muito largo, estava indo muito sangue para o pulmão, quando tentaram extubar ela não tinha respiração suficiente e estava tendo parada respiratória". "Então levaram para a cirurgia e tiraram o stent e colocaram o blalock taussing, que é um tubinho (com a função de direcionar o fluxo de sangue para os pulmões e aliviar a cianose, enquanto a criança está à espera de cirurgia corretiva ou paliativa)".

Por vezes as gestantes necessitam de internação, para tratamento dos bebês intra-útero ou para seu próprio tratamento. A hospitalização, tão comum no seguimento da gravidez de alto risco, deve ser considerada como outro fator estressante adicional. Conscientizasse a grávida da sua doença; é afastada do suporte familiar; vive conflito entre a dependência imposta e a perda de autonomia (perda do controle sobre si e sobre a gravidez) ${ }^{82}$. 
“...Quando ela viu meus exames de diabetes falou que estavam muito alterados. Então, precisei ser internada, passei 30 dias internada, sem nem ir para casa porque eles não me liberavam, tinham que cuidar de mim por causa do bebê".

Os principais impactos vividos pelas participantes foram a mudança no seu cotidiano, o enfretamento da cidade de São Paulo, a convivência com o tratamentos, intervenções e profissionais de saúde.

"Fiquei algumas horas com ele, recebi o boletim médico e fui para a ACTC... Tinha sempre que me manter firme, meu marido estava cuidando da nossa filha e trabalhando, não podia passar o tempo todo em São Paulo comigo".

..."Os médicos iam colocar uma válvula que precisava passar pelo furinho da barriga. Essa válvula ia passar pelo cordão umbilical e ia até a veinha da nenê, que estava entupida e ia encher um balãozinho. Quando o balãozinho enchesse, a veia ia desentupir e eles iam tirar o balãozinho para que o coração voltasse a bater normal, porque um lado, como estava muito forçado, estava grande, mas ele já tinha musculatura para voltar ao tamanho normal. 
“... Fizeram a dilatação e a saturação dela está bem, entraram com corticóide, ela vai ficar intubada até a cicatrização, depois volta todo o processo de novo, CPAP, oxigênio, pensar em mandar para o quarto. Assim fico mais aliviada, porque até então não sabíamos o que estava acontecendo. Agora é só tratar e se Deus quiser vamos embora, porque o coração que é o motivo de estarmos aqui está bom."

A adaptação e o manejo da doença ocorrem quando há respostas ativas dos indivíduos aos desafios em relação a identidade e estilo de vida ${ }^{79}$.

Devem ser levadas em conta, ainda nesse contexto emocional, as reações da família, muito semelhantes às das participantes (ambivalência, culpa, raiva e luto). No grupo familiar, o parceiro desempenha papel importante, por reações que podem manifestarse por meio de apoio e companheirismo ou sentimentos de exclusão, ressentimento, agressividade, culpa e outros ${ }^{68}$.

“... Mudou tudo agora! Quem era e quem é ele agora! Quando ficou sabendo do problema do bebê, se entregou à igreja, agora só vai da igreja para casa e da casa para a igreja"

Uma das estratégias para o enfrentamento dessa vivência, que as participantes utilizam diante da situação da doença de seus filhos é a religião e o apoio da rede social, determinando um comportamento resiliente ${ }^{68}$. 
“... A gente pediu bastante oração para o pessoal lá da cidade, todas as igrejas fizeram corrente de orações. As pessoas ligavam perguntando que dia seria o procedimento para rezar. Claro que isso me passou uma segurança maior, porque confio muito em Deus".

O fortalecimento do vínculo familiar frente às dificuldades advindas com a trajetória da doença é estruturalmente regida por uma série de mitos que servem no processo de constituição subjetiva, como ponto de ancoragem simbólica e imaginária que situa o sujeito em determinado lugar naquele grupo familiar. Seria uma espécie de berço simbólico que transmite como herança a possibilidade de inserção no mundo humano e de viver em uma cultura. Nesse sentido, a cultura é considerada uma espécie de placenta psicossocial, onde se dão as relações familiares de modo ampliado ${ }^{69}$.

A família, por constituir-se complexa em sua estrutura, composição e função, não escapa em vivenciar conflitos múltiplos ao longo do ciclo vital. Enquanto existe está sujeita às transformações, necessitando, muitas vezes, redimensionar-se em suas posturas diante de diversas realidades e adversidades, as quais são submetidas na busca de superação e equilíbrio. Assim como as crises acontecem dentro da família é com ela, que devem ser buscadas as soluções para a nova realidade, que se projeta no viver cotidiano com a doença do filho ${ }^{83}$. 
“... Eu e o meu namorado estamos bem, ele está vendo a nossa casa, vamos morar juntos. Ele está trabalhando, trabalha de manhã e vem à tarde para cá, chega por volta das 17 horas, fica com ela. No começo foi mais difícil, ele voltou a trabalhar, ainda não se acostumou com tudo que está acontecendo, mas se adaptou com a rotina de trabalhar e ter de vir para cá, porque não tem como se acostumar com um filho doente. Quando ela faz cirurgia, ele não vai trabalhar, pega atestado".

“... A gente que é mãe sente quando a criança está bem, e eu vi que ele estava bem melhor e conversei com a minha mãe, com a minha sogra, com o meu marido, dessa vez quis subir para o quarto com ele, me enchi de coragem porque vi que estava bem melhor, agora eu vou".

Outro fator apontado nessa terceira fase diz respeito a desistência de manter relacionamentos sociais. Uma das áreas mais difíceis para se manter relacionamentos normais e mobilizar recursos é o trabalho.

“... No serviço eles tratavam a gravidez como se fosse nada, falavam que eu não estava doente, estava apenas grávida. Se eu faltasse e passasse um atestado no dia seguinte era piada o dia inteiro, ficava aquela coisa de dó, não tinha apoio pelo problema da nenê, estava muito difícil trabalhar. Então ficava só afastando, de atestado, trabalhava um dia me afastava mais dez e então agora vou entrar definitivo em licença, ainda mais na reta final, sem condições de voltar a trabalhar." 
Nessa fala a participante demonstra que seus colegas não são compreensivos e com isso ela prefere o afastamento a continuar neste ambiente que lhe é hostil.

Diante dessas considerações acreditamos que a complexidade do tratamento das crianças com SHCE, exigiu dessas famílias a ruptura da vida diária, enfrentando preocupações e sentimentos ambivalentes em busca de tratamentos e informações que acarretassem a melhora/cura de seus filhos. Mostraram-se adaptadas aos procedimentos propostos e a muitos manejos desconhecidos; gradualmente foram adaptando-se à necessidade de compreender protocolos, exames e internações, que passaram a fazer parte de suas vidas.

Frente ao exposto, apresentamos a seguir a Figura 3 com a representação da trajetória das participantes, seguindo o referencial teórico escolhido nesta investigação.

Figura 3 - Esquema demonstrativo da trajetória de gestantes/puérperas de bebês cardiopatas segundo o referencial de Michael Bury. (São Paulo, 2014).

\section{TRAJETÓRIA DE GESTANTES/PUÉRPERAS DE BEBÊS CARDIOPATAS}

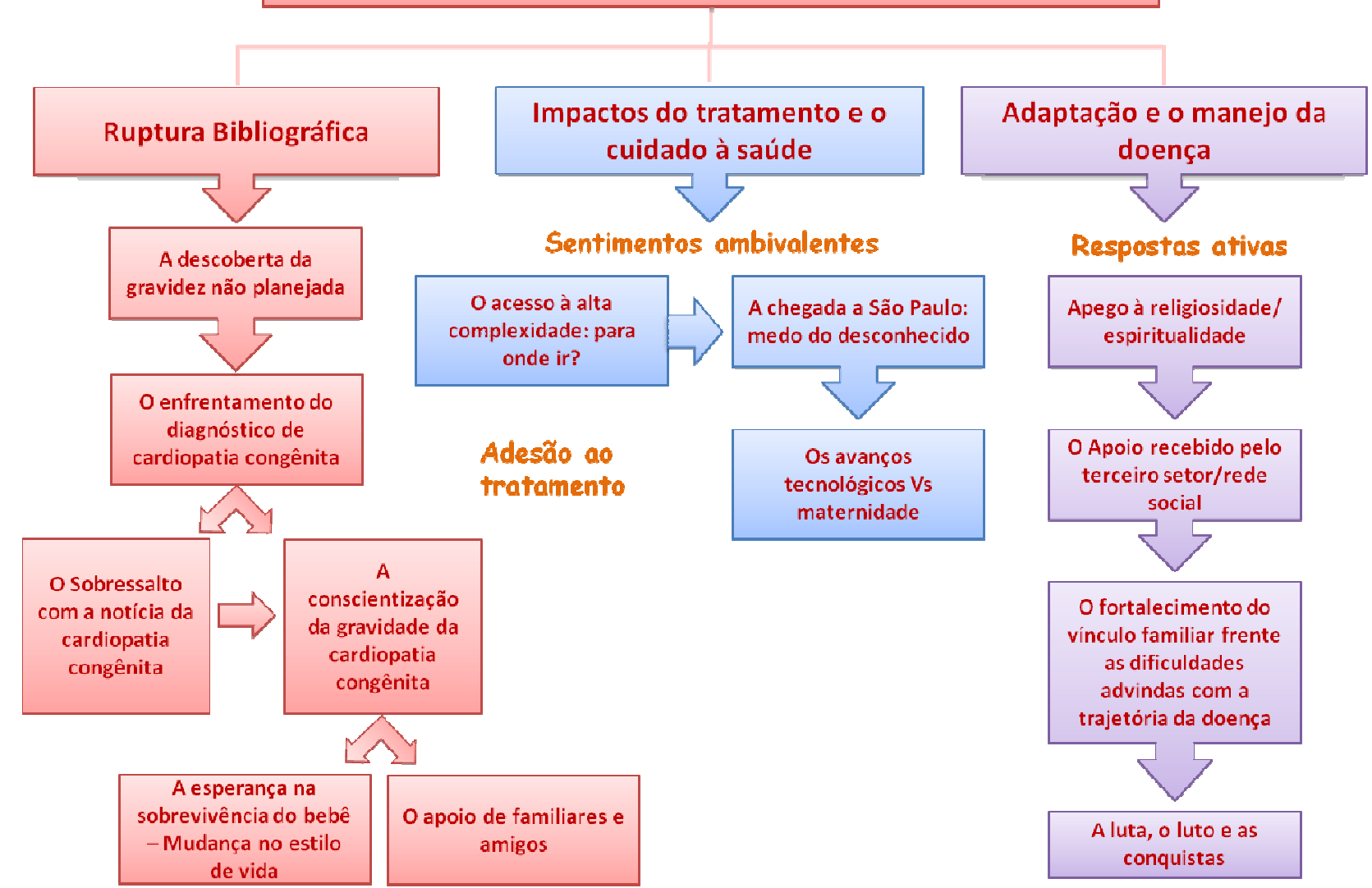


CAPÍTULO 8

AS INTERVENÇÕES PROPOSTAS À UNIDADE DE

CARDIOLOGIA FETAL

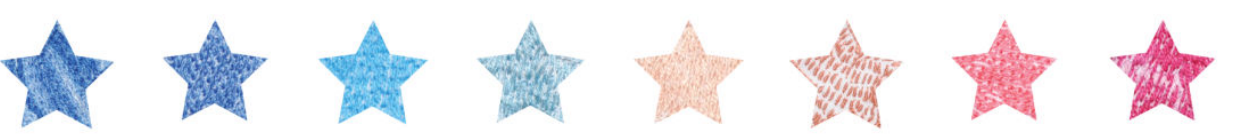



Para que serve a ciência se não for para diminuir a dor da humanidade?

[Minayo, 2013].

O desenvolvimento desta pesquisa permitiu-nos desvelar a lógica das participantes acerca da assistência recebida na Unidade de Cardiologia Fetal, compreender e interpretar suas experiências e, com isso, procurar encontrar o significado atribuído a esse serviço.

Assim, ao descortinar as verdades das falas dessas participantes, além de apreendê-las e compreendê-las, era, agora, preciso relacioná-las às possibilidades de integração ao cenário deste estudo.

O grande desafio foi o de capturar, em meio a períodos de sofrimento e a outros de conquistas pela evolução do estado de saúde de seus filhos, a percepção das gestantes/puérperas com relação ao serviço. Nesse momento, seria, realmente, possível para elas agregar valor e significado a essa Unidade? Contudo, o objetivo desta investigação levava-nos à necessidade desse desdobramento - incorporar a experiência dessas mulheres ao serviço.

Além de ser finalidade desta pesquisa, conhecer a percepção das participantes acerca do serviço prestado era, também, a expectativa da equipe multidisciplinar da Unidade de Cardiologia Fetal; dessa maneira, como abster-nos de integrar essa experiência, propor e implantar melhorias nesse serviço, a partir da visão dessas usuárias?

Sob essa ótica, voltamos novamente às narrativas e às categorias culturais, sobretudo à categoria relativa à avaliação do serviço, ficando, a princípio, evidente a necessidade da realização de uma auto-avaliação por parte da Unidade de Cardiologia Fetal.

Em reunião com as coordenações das equipes médicas e de enfermagem, optamos por reunir a equipe multidisciplinar e desenvolver essa avaliação. Para tanto, propusemos o emprego de uma ferramenta de qualidade, entendendo que esse instrumento permitiria identificar, nos processos de trabalho, os pontos 
apontados como frágeis pelas participantes e o aprimoramento da assistência prestada.

A ferramenta escolhida foi a "Análise SWOT" (sigla inglesa, acrônimo de Strengths/Força, Weaknesses/Fraquezas, Opportunities/Oportunidades e Threats/Ameaças), utilizada para analisar um determinado cenário/ambiente, facilitando a visualização e o entendimento dos problemas; permitindo o conhecimento, a variabilidade e o monitoramento dos processos.

A participação da equipe multiprofissional foi fundamental e todos tiveram oportunidade de refletir sobre a assistência em suas áreas e compartilhar propostas de melhorias; o meu papel, nessa primeira etapa, foi o de apresentar as inquietações demonstradas pelas participantes ou por mim percebidas durante a observação participante.

Trabalhamos com a Análise SWOT nos seus quatro eixos: forças, oportunidades, fraquezas e ameaças. Para evidenciar a incorporação das melhorias, a partir dos pontos fracos levantados, foram estabelecidas três categorias: assistência, recursos humanos e infraestrutura.

As categorias referente à assistência e aos recursos humanos foram as mais trabalhadas e incorporadas a curto prazo, estando os planos de ação relativos a infraestrutura em desenvolvimento.

Desse modo, sob a coordenação da Gerência de Enfermagem, iniciou-se a revisão dos protocolos da Neonatologia, para o aprimoramento do cuidado ao recém-nascido, em conjunto com a equipe multidisciplinar. Nessa oportunidade, foi realizada uma revisão do dimensionamento de pessoal de enfermagem da UTI, e a previsão de uma escala de plantões consecutivos em cada leito, com os mesmos profissionais, a fim de fortalecer o vínculo profissional/paciente/família, podendo ser revisto pela enfermeira sempre que necessário.

Adequações nas orientações às gestantes no atendimento pré-parto, pela equipe de enfermagem, também, foram atualizadas, 
uma vez que tomamos conhecimento que as gestantes ao receber orientações sobre o parto entendiam ser obrigatório o parto cesárea; dessa forma, passamos a orientar que em outras Instituições há a possibilidade da realização do parto normal e que isso não acarretaria quaisquer prejuízos à saúde do bebê. Ademais, a equipe passou a dar mais ênfase aos retornos ambulatoriais, adequando as datas e os horários, bem como estabelecendo uma melhor comunicação institucional.

Outro aspecto a ser destacado diz respeito às reuniões semanais que passaram a ser realizadas com os pais dos recémnascidos internados no setor, para alinhar suas necessidades em conjunto com a equipe multidisciplinar, que presta o cuidado, bem como uma reunião reservada com a participação dos pais, enfermagem, médico responsável e psicologia, para os pacientes que permanecem por um período maior que 15 dias, no intuito de tranquilizar acerca do tratamento do bebê.

Nessa direção, a Supervisão de Enfermagem passou a atender a todos os pais semanalmente para conhecer o nível de satisfação quanto ao atendimento de enfermagem e as necessidades de ajustes que, eventualmente, possam surgir.

Essas alterações culminaram na atualização do Regimento Interno da Unidade de Cardiologia Fetal, conforme citações a seguir.

\section{Art. $12^{\circ}$ Compete à Equipe de Enfermagem:}

X. Acolher a puérpera durante o período de internação, auxiliando nas necessidades por eles apresentadas.

XI. Proporcionar o aumento do vínculo na UTI neonatal da equipe com a puérpera a fim de transmitirmos mais confiança ao cuidado prestado.

XII. Estar sempre disponível para discutirmos melhorias do cuidado ao recém-nascido junto as puérperas.

Foram incorporadas também no Regimento Interno da Unidade de Cardiologia Fetal orientações nutricionais para as gestantes no pré-natal e desenvolvidos e implantados protocolos de terapia nutricional, para otimizar aporte calórico e protêico dos 
pacientes, buscando parceria com a Equipe Multiprofissional de Terapia Nutricional (EMTN) do HCor.

\section{Capítulo V - Do pessoal e suas atribuições}

\section{Art. $4^{\circ}$ Compete à Equipe de Nutrição:}

I. Identificar as gestantes sob risco nutricional e que necessitam de avaliação e acompanhamento nutricional (baixo peso, sobrepeso, obesidade, inapetência persistente, diabetes e/ou hipertensão pregressa à gestação ou diabetes gestacional e/ou doença hipertensiva específica da gestação;

II. Avaliar as gestantes quanto às suas necessidades nutricionais, corrigir possíveis deficiências e propiciar adequado ganho ponderal de acordo com a idade gestacional;

III. Realizar a orientação nutricional adequada para cada caso;

IV. Acompanhar a evolução do estado nutricional e reavaliar de acordo com os critérios estabelecidos;

V. Proporcionar evolução adequada do estado nutricional da gestante, garantindo melhores resultados e qualidade de vida para a mãe e o recém-nascido;

VI. Registrar todos os atendimentos prestados em ficha específica e arquivar na Nutrição Clínica.

Outrossim, a equipe de fisioterapia que até então não participava efetivamente dos processos de trabalho da equipe multidisciplinar, foi incorporada à Unidade de Cardiologia Fetal.

\section{Art. $14^{\circ}$ Compete à Equipe de Fisioterapia:}

I. Prestar assistência fisioterapêutica da UTI à Unidade de Internação aos neonatos nascidos no HCor e às respectivas mães (puérperas) de acordo com prescrição médica;

II. Prestar assistência respiratória de acordo com a avaliação do diagnóstico fisioterapêutico;

III. Desenvolver o plano fisioterapêutico condizente com a avaliação de perda funcional e respiratória, traçar metas terapêuticas e registrar nos impressos de avaliação de Capacidade Funcional;

IV. Registrar em prontuário a conduta realizada e o planejamento terapêutico.

Além das medidas supra citadas, cabe salientar, que os achados desse estudo forneceram subsídios para as discussões 
entre as diferentes categorias profissionais, procurando a integralidade do cuidado na área neonatal.

Para o alcance dessa integralidade, muito projetos ainda necessitam ser desenvolvidos. Como dissemos faltam os projetos de infraestrutura e outros destinados a continuidade do atendimento em nível ambulatorial. Ressalta-se, assim, projeto que vem sendo articulado pela equipe de enfermagem, visando sua efetiva inserção no âmbito ambulatorial.

Assim, conhecer como as gestantes/puérperas perceberam e avaliaram o atendimento prestado foi de suma relevância para repensar a forma de organização do serviço, evidenciando o papel do usuário como protagonista do sistema de saúde, cujas contribuições podem ter um impacto direto na melhoria do serviço.

O olhar para a Unidade de Cardiologia Fetal inspira a busca de melhorias que possam ser significativas a ponto de usar o passado como referência, fazer o presente melhor, avaliando continuamente o desempenho da equipe, para sonhar com o futuro, onde comprometidos e fortalecidos pelo apoio mútuo, possamos assistir cada vez com mais qualidade e segurança. 

CAPÍTULO 9

AS PERSPECTIVAS E OS DESAFIOS FRENTE ÀS POLÍTICAS DE SAÚDE

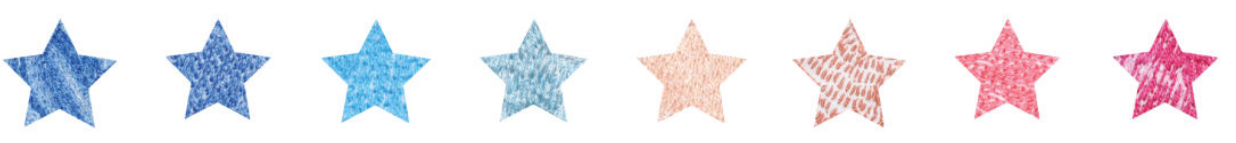



As ciências sociais, nos espaços institucionais, enriqueceram as reflexões sobre a saúde e doença, como fenômenos existenciais e societários, individuais e coletivos, e como objetos das intervenções políticas, dos saberes, tecnologias e terapêuticas das equipes de saúde.

Assim, a pesquisa qualitativa proporciona uma extrapolação do locus institucional da área da saúde, pois a saúde e doença transformam-se e influenciam-se pelos novos objetos, simultaneamente, pertencentes à natureza e à cultura.

A saúde pública no Brasil vem progredindo nas últimas décadas em especial com a consolidação do SUS, contudo muitos são os desafios para que os objetivos sejam atingidos, como consta na Constituição Federal. A desigualdade no Brasil figura entre nossos piores indicadores e os recursos financeiros insuficientes e a ineficiência dos serviços de saúde são exemplos das dificuldades que precisam ser enfrentadas e superadas ${ }^{84}$.

$\mathrm{Na}$ área materno-infantil, também, foram evidenciados avanços, observados pela melhoria da atenção ao parto e ao nascimento, fruto de uma série de esforços e iniciativas governamentais e da sociedade. Todavia a redução da morbimortalidade materna permanece, ainda, como uma meta a ser atingida em nosso País.

Como vimos anteriormente, no que tange aos indicadores de mortalidade neonatal, são ainda preocupantes e, de acordo com o descrito neste estudo, as cardiopatias congênitas são uma das grandes responsáveis por esses índices.

A mortalidade decorrente das cardiopatias congênitas seria drasticamente reduzida se todos os cuidados pré e pós-natais fossem devidamente instituídos. No entanto, o rastreamento não garante que o acesso ao cuidado seja atingido, principalmente, as cardiopatias mais graves, como a SHCE.

$\mathrm{O}$ HCor tem mantido persistente solidariedade com crianças com diagnóstico de doenças cardíacas, chegando ao momento atual 
de hospital participante do PROADI-SUS.

Hoje o HCor apoia a criação de um centro de referência em cirurgia cardiopediátrica e neonatal para a Região Amazônica e serve de referência nacional para o SUS, nos casos de cirurgias fetais e neonatais complexas.

Os principais desafios do HCor perpassam pela busca contínua de um serviço que tenha como pressuposto análises críticas e diagnósticas, onde seja possível analisar e avaliar o desempenho em busca de transformações, cujos pilares sejam o cuidado integral e a segurança do paciente, cimentados em assistência qualificada, que só será alcançada se houver interlocução interdisciplinar ${ }^{85}$.

Nessa direção, acreditamos que a capacitação, a transferência de tecnologia associada a uma saúde baseada em evidências e a contínua parceria com a academia, lugar em que a pesquisa em saúde seja um componente para fortalecer as políticas nacionais em saúde, são elementos indispensáveis para a assistência qualificada.

Para tanto, a parceria entre o HCor e o PROADI-SUS poderia ser expandida para outras macrorregiões do Brasil, para os centros referenciados na área da cardiologia neonatal e pediátrica, com potencial para desenvolver habilidades para $\circ$ atendimento de crianças com diagnóstico de cardiopatias graves, minimizando as desigualdades regionais. Seria a possibilidade de que mais crianças cardiopatas tivessem a oportunidade de assistência, e alcançassem todo seu potencial cognitivo e motor, em especial nos seus primeiros 24 meses de vida.

Corroborando, assim, com um dos aspectos que vem sendo preconizado pelo diretor geral desta instituição - Dr. Adib Jatene, conhecido e respeitado internacionalmente, como inventor de uma cirurgia do coração, para o tratamento das grandes artérias em recém-nascidos, ao longo de sua incansável luta pela saúde pública no Brasil. 
REFERÊNCIAS

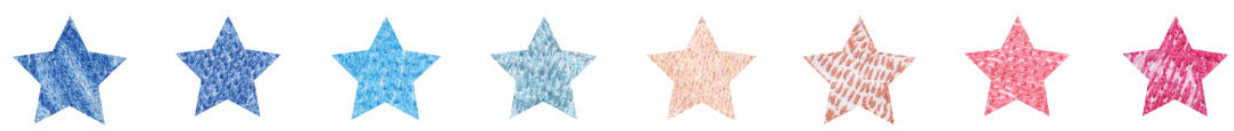



1. Organização das Nações Unidas . Oito jeitos de mudar o mundo[internet]. [citado 2013 out. 05]. Disponível em: http://www.objetivosdomilenio.org.br/

2. Victora CG, Aquino EM, Leal MC, Monteiro CA, Barros FC, Szwarcwald CL. Saúde de mães e crianças no Brasil: progressos e desafios. The Lancet. 2011; 32-46.

3. Brasil. Ministério da Saúde.DATASUS. Informações de Saúde. Informações de Mortalidade. Painel de monitoramento da mortalidade materna. [Internet] . Brasília; 2013. [citado 2013 nov. 15]. Disponível em: http://svs.aids.gov.br/dashboard/mor talidade/materna.show.mtw

4. Brasil.Ministério da Saúde. Portaria $n^{\circ} 1020$ de 29 de maio de 2013. Institui as diretrizes para a organização da Atenção à Saúde na Gestação de Alto Risco e define os critérios para a implantação dos serviços de referência à Atenção à Saúde na Gestação de Alto Risco, incluída a Casa de Gestante, Bebê e Puérpera (CGBP), em conformidade com a Rede Cegonha. [Internet]. Brasília; Ed. Ministério da Saúde; 2013. [citado 2013 nov. 18] Disponível em: http://bvsms.saude.gov. br/bvs/saudelegis/gm/2013/prt1020_29_05_2013.html

5. Dornfeld D, Pedro ENR. A comunicação como fator de segurança e proteção ao parto. Rev Eletr Enf. 2011; 13(2):190-198.

6. Brasil. Ministério da Saúde. Portaria 1459 de 24 de junho de 2011. Institui, no âmbito do Sistema Único de Saúde - SUS - a Rede Cegonha. [Internet] .Brasília; 2011. [citado 2013 nov 18]. Disponível em: http://bvsms.saude.gov.br/bvs/saudelegis/gm/2011/prt1459_24 _06_2011.html

7. Melleiro MM. Análise das dimensões de qualidade oriundas de modelos avaliativos em saúde [tese]. São Paulo: Escola de Enfermagem, Universidade de São Paulo, 2010.

8. The Health Foundation. Medição e monitoramento da segurança. Rio de Janeiro:Proqualis/Instituto de Comunicação Científica e Tecnológica em Saúde/Fiocruz; 2013.

9. Viñals F. Cardiopatias congenitas incidencia antenatal. Rev Chilen Obst Ginecol. 2002; 67(3):203-206.

10 Zielinsky P. Malformações cardíacas fetais: diagnóstico e conduta. Arq Bras Cardiol. 1997; 69(3):209-211.

11. Barber-Marcial M, Tanamati C. Síndrome da hipoplasia do coração esquerdo. In: Santana MVT. Cardiopatias do recém- 
nascido: diagnostico e tratamento. São Paulo: Atheneu; 2005. p. 126-135.

12. Hospital do Coração. Protocolos assistenciais da cardiopediatria - Filantropia do HCor [internet]. São Paulo: HCor; 2012. Disponível em: http://www.hcor.com.br

13. Flyer DC. Report of the New England Regional Infant Cardiac program. Pediatrics. 1980; 65:436-439.

14. Brenner JI, Kuehl K. Hypoplastic left heart syndrome and other left heart disease. Cardiology in the young. 2011; 21(suppl2):23-27.

15. Nguyen T, Miller M, Gonzalez J, Naedell K, Galas J, et al. Echocardiography of hypoplastic left heart syndrome. Cardiology in the young. 2011; 21(suppl2):28-37.

16. Gordon BM, Rodriguez S, Lee M, Chang RK. Decreasing Number of Deaths of Infants with Hypoplastic Left Heart Syndrome. J Pediatr. 2008; 153:354-358.

17. Andrews R, Tulloh R, Sharland G, Simpson j, Rollings S, Baker $E$. Outcome of staged reconstrutive surgery of hypoplastic left heart syndrome following antenatal diagnosis. Arch Dis Child. 2001; 85:474-477.

18. Tworetzky WMD, Reddy M, Brook NM, Hanley F, Silvermann $\mathrm{NH}$. Improved surgical outcome after fetal diagnosis of hypoplastic left heart syndrome. Circulation. 2001; 103:12691273.

19. Pequenos corações. O que é a síndrome de hipoplasia do coração Esquerdo? [internet] [citado 2013 dez. 18]. Disponível em: http://www.pequenoscoracoes.com/shce.html

20. Sá Neto JA. Tecnologia como fundamento do cuidar em neonatologia. Texto contexto - Enferm. 2010; 19(2):372-377.

21. Chazan L K. As imagens fetais e a produção do prazer de ver. Mnemosine. 2005; 1(1):347-363.

22. Bacaltchuk T. Rastreamento Pré-natal de Anormalidades Cardíacas: Papel da Ultra-sonografia Obstétrica de Rotina. Rev Bras Ginecol Obstr. 2001; 23(9):553-558.

23. Brasil.Presidência da República.Casa Civil. Decreto 7508 de 28 de junho de 2011. Regulamenta a Lei no 8.080, de 19 de setembro de 1990, para dispor sobre a organização do Sistema Único de Saúde - SUS, o planejamento da saúde, a assistência à saúde e a articulação interfederativa, e dá 
outras providências. [internet]. Brasília: 2011.[citado 2013 dez. 01] Disponível em: http://www.planalto.gov.br/ccivil_03/_ato 2011-2014/2011/decreto/D7508.htm.

24. Santos TVC. Acesso aos serviços de saúde: perspectiva de profissionais e usuários [Internet]. Minas Gerais: Escola de Enfermagem, Universidade Federal de Minas Gerais; 2001. [citado 2013 dez.14]. Disponível em: http://www.biblioteca digital.ufmg.br/dspace/handle/1843/GCPA-93ZLJZ.

25. Reis DC. Acesso da população ao diagnóstico e tratamento da esquistossomose em área endêmica do município de Jequitinhonha, Minas Gerais [Internet]. Minas Gerais: Escola de Enfermagem, Universidade Federal de Minas Gerais; 2009 [citado dez.15]. Disponível em: http://www.bibliotecadigital. ufmg.br/dspace/handle/1843/GCPA-7QWJCU.

26. Brasil. Ministério da Saúde.Secretaria de Atenção à saúde. Departamento de Ações Programáticas Estratégicas. Ações programáticas estratégicas. $5^{\mathrm{a}}$ ed. Brasília: Editora do Ministério da Saúde; 2012.

27. Pires D, Fertonani HP, Conill EM, Matos TA, Cordova FP, Mazur CS. A influência da assistência profissional em saúde na escolha do tipo de parto: um olhar sócio antropológico na saúde suplementar brasileira. Rev Bras Saúde Mater Infant. 2010; 10(2):191-197.

28. Penna CMM, Brito MJ, Porto F. Equity and resolution: of theory to construction in daily of health professionals. [Internet]. Online Brazilian Journal of Nursing. 2007; 6(3):1091. [cited 2013 dec. 18]. Available from: http://www.objnursing.uff.br/index.php/nursing/ issue/view/8

29. Brasil. Ministério da Saúde. Datasus. Central Nacional de Regulação da Alta Complexidade. CNRAC.[Internet]. Brasília.[citado 2013 nov 18]. Disponível em http://cnrac.datasus.gov.br/cnrac/app/publica.jspx

30. Minayo MCS. Pesquisa social: teoria,método e criatividade. $25^{\mathrm{a}}$ ed. Rio de Janeiro: Vozes; 2007.

31. Victora CG, Knauth, DHM. Pesquisa qualitativa em saúde; uma introdução ao tema. Porto Alegre: Tomo; 2000.

32. Chizzotti AA. A pesquisa qualitativa em ciências humanas e sociais: evolução e desafios. Rev Port Ed. 2003; 16(2):221236.

33. Melleiro MM, Gualda DMR. Experiências e Expressões de Gestantes na Interação com Sistema de Saúde: um enfoque 
fotoetnográfico. Rev Latino-Am Enfermagem. 2004; 12(3):503-510.

34. Benjumea CC. Características de La investigación cualitativa y su relacion com La enfermeria. Invest Educ Enferm. 1997; 25(2):13-24.

35. Minayo MCS. O desafio do conhecimento. $14^{\mathrm{a}}$ ed. São Paulo: Hucitec; 2010.

36. Denzin N. Planejamento da pesquisa qualitativa: teorias e abordagens. Porto Alegre: Artmed; 2006.

37. Couto MT, Pinheiro TF, Valencia O, Machin R, Silva GSN, Gomes, R, Schraiber LB, Figueiredo WS. O homem na atenção primária à saúde: discutindo (in) visibilidade a partir da perspectiva de gênero. Interface. 2010;14(33): 257-270.

38. Rabelo, MC. Experiência de doença e narrativa. Rio de Janeiro: Fiocruz; 1999.

39. Alves PC. Saúde e doenças: um olhar antropológico. Rio de Janeiro: Fiocruz; 1994.

40. Geertz C. A Interpretação das Culturas. Rio de Janeiro: Zahar;1989.

41. Laraia R. Cultura: um conceito antropológico. Rio de Janeiro: Zahar; 2009.

42. Gualda DMR. Eu conheço minha natureza: um estudo etnográfico da vivência do parto. Paraná: Ed Maio; 2002.

43. Uchôa E, Vidal JM. Antropologia médica: elementos conceituais e metodológicos para uma abordagem da saúde e da doença. Cad Saúde Publ. 1994; 10(4):497-504.

44. Gualda DMR. A experiência, o significado e a realidade da enfermeira obstetra: um estudo de caso [tese]. São Paulo: Escola de enfermagem: Universidade de São Paulo; 1998.

45. Strauss C, Quinn N. A cognitive theory of cultural meaning. Cambridge: Cambridge University Press; 1997.

46. Nakamura E. O lugar do método etnográfico em pesquisas sobre saúde doenças e cuidado. A Antropologia para enfermagem. São Paulo: Manole; 2009.

47 Meihy JCSB, Holanda F. História oral: como fazer como pensar. São Paulo: Contexto; 2007. 
48. Haguete TMF. Metodologias qualitativas na sociologia. Petrópolis: Manole; 2001.

49. Meihy JCSB. Manual de história oral. São Paulo: Loyola; 1998.

50. Heyl BS. Ethnographic interviewing. Handbook of ethnography. London: Sage; 2001. p. 369-383.

51. Hospital do Coração. [internet]. [citado 2013 dez 06] Disponível : http://www.hcor.com.br/

52. Brasil. Ministério da saúde.Conselho Nacional de Saúde. Comitê Nacional de Ética em Pesquisa. Resolução 196/96.[internet]. Brasília: Ed. Ministério da Saúde; 1996. [citado 2013 nov. 02]. Disponível em: http://conselho.saude.gov.br/resolucoes/reso_96.htm.

53. Rocha AA, Macedo C. Bordar a vida: histórias das mulheres da ACTC. São Paulo: ACTC; 2012.

54. Cabtree B, Miller WL. Doing qualitative research. Newbury: Sage; 1992.

55. Mattingly C, Garro LC. Narrative representations of illness and healing. Soc Sci Med. 1994; 38(6):771-774.

56. Denzin N. Intrepretative interactionism. London: Sage; 1989.

57. Garro LC. Narrative representations of chronic illness experiencie: cultural models of illness, mind and body in stories concerning the temporomandibular joint. Soc Sci Med. 1994; 38(6):775-788.

58. Atikinson P. The ethnographic imagination: textual constructions of reality. New York: Routledge; 1990.

59. Riessman CK. Narrative analysis: qualitative research methods. Newbury: Sage; 1993.

60. Rosaldo R. Culture and truth: the remaking od social analysis. London: Routledge; 1993.

61. Sarbin TR. Narrative psychology. New York: Praeger; 1986.

62. Janesick VJ. The choreography of qualitative research design. Handbook of qualitive research. London: Sage; 1995.

63. Gutman L. A Maternidade e o encontro com a própria sombra. Rio de Janeiro: Record; 2010. 
64. Sanches NC, Mamede FV, Vivancos RBZ. Perfil das mulheres submetidas à cesariana. Texto e Contexto - Enferm. 2013; 21(2):418-426.

65. Patricio SF. Construindo mecanismos mais resilientes de enfrentamento em pais de crianças deficientes um caminho possível para intervenções mais eficazes.[Internet] [citado 2014 jan 06]. Disponível: http://www.institutogerar. com.br/artigos/51_Construindo_mecanismos_mais_resilientes 2011[1].pdf

66. Miele MJ. Mãe de UTI: amor incondicional. São Paulo: Terceiro Nome; 2000.

67. Ismael SMC. Psicologia Hospitalar: Sobre o Adoecimento, Articulando conceito com a prática clínica. São Paulo: Atheneu; 2013.

68. Salgado CL, Lamy ZC, Nina RVAH, Melo LA, Lamy Filho F et al. A cirurgia cardíaca pediátrica sob o olhar dos pais: um estudo qualitativo. Rev Bras Cir Cardiovasc. 2011; 26(1):3642.

69. Barros IPM. Movimentos do desejo materno antes e após o nascimento do filho: um estudo longitudinal [tese]. São Paulo: Escola de Enfermagem, Universidade Federal de São Paulo; 2010.

70. Cabral FB, Hirt LM, Van der Sand ICP. Atendimento pré-natal na ótica de puérperas: da medicalização à fragmentação do cuidado. Rev Esc Enferm USP. 2013;47(2):281-287.

71. Tomaz CMM. Memória de mulheres: lembranças e identidades de mulheres brasileiras da ACTC. [internet]. São Paulo: Ciências Socias, Pontifícia Universidade Católica de São Paulo; 2010.[citado 2013 dez. 18]. Disponível em: http://www.dominiopublico.gov.br/pesquisa/DetalheObraForm. do?select_action\&co_obra=140537

72. Dourado VG, Pelloso SM. Gravidez de alto risco: o desejo e a programação de uma gestação. Rev Paul Enf. 2007; 20(1):6974.

73. Geocze C. Desvelando os segredos do feto: experiências de mulheres grávidas submetidas ao ultra-som obstétrico [tese]. São Paulo: Escola de Enfermagem, USP; 2009.

74. Guimarães HP, Avezum A. O impacto da espiritualidade na saúde física. Rev. Psiq Clín. 2007;34(supl 1):88-94. 
75. Souza AL, Wottrich SH, Seelig C, Vigueras ESR, Ruschel PP. O acompanhamento psicológico a óbitos em unidade pediátrica. Rev da SBPH. 2007; 10(1):151-160.

76. Tronchin DMR, Melleiro MM, Tsunechiro MA, Gualda D M R. O olhar dos usuários de um Hospital de Ensino: uma análise da qualidade assistencial às gestantes e aos recém-nascidos. Texto Contexto - Enferm. 2006; 15:401-408.

77. Corrêa CRH, Bonadio IC, Tsunechiro MA. Avaliação normativa do pré-natal em uma maternidade filantrópica de São Paulo.

Rev Esc Enferm USP. 2011;45(6):1293-1300.

78. Vieira SM, Bock LF, Zocche DA, Pessota CU. Percepção das puérperas sobre assistência prestada pela equipe de saúde no pré-natal. Texto Contexto - Enferm. 2011; 20:255-262.

79. Bury M. Health and illness in a changing society. London: Routledge; 1997.

80. Lima AFC, Gualda DMR. O significado da hemodiálise para o paciente renal crônico: utilização de um modelo para interpretação de dados de pesquisa qualitativa. Rev Paul Enf. 2001;20;44-51.

81. Bury M. Doença crônica como ruptura biográfica. Tempus. Actas de Saúde Coletiva. 2011;5(2);41-55.

82. Assis ILR, Cadete MM, Rios RR. Gravidez de alto risco: percepção das gestantes. In: VI Congresso Brasileiro de Enfermagem Obstétrica; 2009 jun. 1-39; Teresina, PI.

83. Brandilize DL. Um marco conceitual para o cuidado ao familiar da criança com cardiopatia congênita à luz da teoria de Roy. Congitare Enferm. 2006;11(3):264-70.

84. Carvalho G. A saúde pública no Brasil. Estudos avançados. 2013; 27(78):7-26.

85. Weber B, Demeneghi L. Assistência Integral. Porto Alegre: Age; 1997. 

APÊNDICES

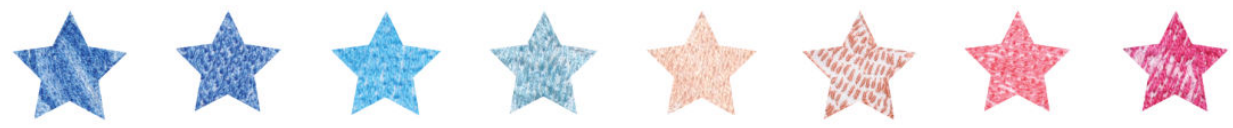





\section{APÊNDICE A - TERMO DE CONSENTIMENTO LIVRE E ESCLARECIDO}

\section{“PERCEPÇÃO DE GESTANTES USUÁRIAS DE UM SERVIÇO DE \\ CARDIOLOGIA E MEDICINA FETAL EM UM HOSPITAL FILANTRÓPICO: UMA ABORDAGEM ETNOGRÁFICA”.}

Este estudo tem como objetivo compreender a experiência das gestantes que recebem o diagnóstico de malformações cardíacas de seus bebês. Esses dados irão ajudar a perceber se o trabalho assistencial de acolhimento, prestado pela equipe que atende as gestantes da Unidade de Medicina Fetal, desse Hospital de Filantropia é efetivo ou não.

Se você quiser participar desta pesquisa, os encontros acontecerão no HCor e a entrevista poderá ser feita no local onde você escolher e o horário será combinado entre você e a pesquisadora, conforme o que melhor lhe convier.

Essa pesquisa é composta por alguns dados gerais de identificação em relação a você mesma, a sua história e sua experiência com relação a ser gestante de um bebê com malformação cardíaca. Alem disso você será solicitada a responder quatro questões abertas. Esta pesquisa não apresenta nenhum tipo de risco. A sua entrevista será gravada, para que possam ser aproveitadas todas as coisas que você falar, mas você tem a garantia que esta conversa é sigilosa, utilizada apenas para o uso de trabalhos científicos e se você quiser retirar alguma coisa da entrevista, mesmo depois de gravada, pode fazê-lo sem nenhuma preocupação.

Caso você concorde em participar, leia atentamente a próxima página, pergunte sobre qualquer detalhe que não entender e assine o documento, autorizando desta forma que os dados colhidos na sua entrevista sejam utilizados nessa pesquisa.

$\mathrm{EU}$, declaro que

concordo em participar da pesquisa intitulada "A experiência de gestantes atendidas em unidade de cardiologia e Medicina Fetal- abordagem etnográfica" que tem como finalidade desenvolver uma pesquisa qualitativa, com o objetivo de compreender a experiência das gestantes que recebem o diagnóstico de malformações cardíacas de seus bebês. 
Declaro ainda, que fui esclarecida sob os seguintes aspectos:

1. Estou participando por minha livre vontade e concordo que a minha entrevista seja gravada e os dados colhidos sejam usados para fins de pesquisa, podendo ser publicados em revistas científicas, divulgados nos meios acadêmicos (universidades, escolas) e/ou apresentados em eventos (congresso, seminários e outros);

2. Minha participação é espontânea, e estou ciente que posso desistir a qualquer hora de participar da pesquisa e que, se isso acontecer, não terei qualquer tipo de punição, prejuízo ou conseqüência;

3. Tenho a garantia da pesquisadora que as informações que darei durante a entrevista não serão divulgadas para outro fim, a não ser para o sua pesquisa, e que a minha identidade será preservada. Que a pesquisadora estará disponível para quaisquer esclarecimentos que se fizerem necessários sobre esse trabalho, durante o tempo que essa pesquisa demorar e que posso encontrá-la no endereço e telefone que estão escritos logo abaixo;

4. Que vou ficar com uma cópia deste termo de consentimento, permanecendo a outra cópia com a pesquisadora.

São Paulo, de de

Participante

Pesquisadora Enilda Maria de Sousa Lara

Tel. 11 8126-0238 / 3053-6611 r. 8451

e-mail: elara@hcor.com.br

Comitê de Ética EEUSP:

Telefone: (11) 3061-7548

Av. Dr. Enéas de Carvalho Aguiar, 419, São Paulo, SP

CEP: 05403-000

e-mail: edipesq@usp.br

Comitê de Ética HCor:

Telefone: (11) 3886-4688

Rua Abrão Dib, 50 - Térreo, Paraíso, São Paulo, SP

CEP: 04004-030

e-mail: etica.pesquisa@hcor.com.br 


\section{APÊNDICE B - Roteiro da Entrevista}

Entrevista $n^{\circ}$

Data I I _ Horário: $:$

\section{DADOS COMPLEMENTARES}

Nome: Idade:

Naturalidade:

Estado Civil:

Religião:

Companheiro Idade:

Endereço: Telefone:

Pré-natal: $\mathrm{N}^{\mathrm{o}}$ de consultas no HCor

Data do nascimento do bebê:

\section{QUESTÕES NORTEADORAS}

\section{Primeira entrevista}

$\checkmark$ Como foi para você ter recebido o diagnóstico de cardiopatia de seu filho?

$\checkmark$ Como foi a sua vinda ao HCor?

\section{Segunda entrevista}

$\checkmark$ Como você foi recebida pela equipe de saúde do HCor?

$\checkmark$ Como foi sua experiência no HCor?

\section{IMPRESSÕES DA PESQUISADORA}



ANEXOS

\section{ANEXOS}





\section{ANEXO 1 - Regimento da Unidade Fetal}

\section{Regimento da Unidade Fetal \\ Parte Geral}

Título I- Da Formação da Equipe

- Cinco ecocardiografistas fetais

- Dois obstetras

- Especialista em cirurgia e medicina fetal

- Dois Neonatologista para sala de parto

- Enfermagem especializada em obstetrícia.

- Duas Assistentes sociais,

- Duas Psicólogas

- Duas Nutricionistas

- Equipe de fisioterapia com especialização em cardiologia ou pediatria

- Fisioterapeutas

- Toda equipe clínica, cirúrgica, intervencionista e diagnóstica da Cardiologia Pediátrica

\section{Capítulo I - Da finalidade do serviço}

Art. $1^{\circ}$

Objetivo principal:

I. Diagnóstico pré-natal de malformações cardíacas

II. Diagnóstico pré-natal de malformações extracardíacas e cromossomopatias.

III. Terapêutica pré-natal quando necessária

$$
\text { - } \quad \text { intervencionista }
$$

IV. Atendimento ao parto de fetos que necessitam atendimento neonatal imediato em cardiologia e cirurgia pediátrica.

\section{Capítulo II - Da organização}

\section{Art. $2^{\circ}$}

- Coordenador do serviço;

- Médicos assistentes das diferentes Especialidades;

- Equipe Multidisciplinar: Enfermagem, Psicologia, Serviço Social, Nutrição e Fisioterapia.

\section{Capítulo III - Das competências}

Art. $3^{\circ}-\mathrm{O}$ atendimento ao parto fica restrito a fetos portadores de cardiopatias ou malformações congênitas que necessitam atendimento cardiológico ou cirúrgico logo após o nascimento, conforme relação abaixo:

\section{CARDIOPATIAS}

I. Cardiopatias com fluxo pulmonar dependente do canal arterial patente: 
- Estenose Pulmonar Crítica

- Atresia pulmonar com septo íntegro

- Atresia pulmonar com CIV

- CC complexas com estenose pulmonar ou atresia pulmonar

- Anomalia de Ebstein com atresia pulmonar funcional

II. Cardiopatias com fluxo sistêmico dependente do canal arterial patente:

- Estenose Valvar Aórtica Crítica

- Atresia aórtica

- Síndrome de Hipoplasia do Coração Esquerdo

- Interrupção do Arco Aórtico

- Coarctação Aórtica isolada ou como parte de outras cardiopatias

III. Cardiopatias que dependem de mistura intracardíaca:

- Transposição das grandes artérias

- Drenagem anômala total de veias pulmonares

- Atresia mitral

IV. Outras anomalias:

- Tronco arterioso comum

- Tumores obstrutivos

- Miocardiopatias com repercussão hemodinâmica

- Bloqueio atrioventricular total

- Taquiarritmias

- Hidropisia fetal de origem cardíaca

\section{MALFORMAÇÕES EXTRACARDÍACAS DIAGNOSTICADAS INTRA-ÚTERO}

- Hérnia diafragmática

- Atresia ou outras anomalias de traqueia

- Atresia de esôfago

- Obstruções intestinais

- Uropatias obstrutivas graves

- Malformações do SNC que necessitem de atendimento neonatal imediato

Art. $4^{\circ}$

Em casos de malformações que não se encontrem na lista acima, a decisão de realizar ou não o parto na Instituição fica a cargo do Coordenador e dos médicos assistentes da Unidade Fetal, que irão avaliar os benefícios do nascimento na Instituição para mãe e bebê.

Art. $5^{\circ}$

Não haverá atendimento obstétrico de urgência no Pronto Socorro da Instituição. Gestantes com suspeita de trabalho de parto antes da data programada deverão entrar em contato com as equipes de enfermagem e médica que farão as orientações pertinentes a cada caso:

- Gestantes do programa de filantropia serão orientadas a procurar o pronto socorro da Maternidade de Referência da rede pública já designada durante $o$ atendimento pelo serviço social.

- Gestantes cujo atendimento será coberto por planos de saúde ou pela família deverão se comunicar com a equipe de obstetrícia que irá definir se o parto poderá ou não ser realizado naquele 
momento no HCor, levando em consideração disponibilidade dos médicos obstetras e neonatologistas, da sala cirúrgica, da vaga na UTI neonatal e Unidade de Internação.

- Gestantes com suspeita clínica de descolamento prematuro de placenta, eclampsia, pré-eclampsia ou qualquer outra emergência médica que ponha em risco a vida da gestante deverão ser orientadas a procurar a maternidade mais próxima da sua residência mantendo a equipe do HCor informada sobre a evolução do caso.

- A equipe da Unidade Fetal irá então verificar a possibilidade de transferência do recém-nascido assim que haja condições clínicas para tal.

Art. $6^{\circ}$

Os partos serão realizados pela equipe de obstetrícia do HCor ou pelo obstetra da paciente. Este último deverá receber autorização do setor de cadastramento médico após apresentação de documentos pertinentes solicitados pelo setor. A equipe de obstetrícia do HCor ficará disponível para auxiliar este médico caso ele necessite, garantindo o bom atendimento da gestante.

Art. $7^{\circ}$

$\mathrm{O}$ atendimento do neonato na sala de parto será realizado pela equipe de Neonatologia e da UTI pediátrica do HCor.

\section{Capítulo IV - Do pessoal e suas atribuições}

Art. $8^{\circ}$ - Compete ao Coordenador do Serviço:

I. Coordenar as atividades da Unidade Fetal de modo que todos os profissionais envolvidos no atendimento da gestante e do recém-nascido sigam as normas, cronogramas e a rotina estabelecidos pelo grupo, permitindo o bom andamento do serviço;

II. Reportar à diretoria do Hospital os resultados, as necessidades, demandas e o andamento do serviço.

III. Decidir junto com o médico de referência se há benefícios em realizar o parto dentro do HCor a depender da malformação fetal.

IV. Participar do diagnóstico, da consulta de aconselhamento e das decisões terapêuticas pré e pós-natais dos pacientes que fazem parte do Projeto de Filantropia.

V. Manter bom relacionamento e interação com a equipe multidisciplinar para que as atribuições referentes a cada grupo sejam desenvolvidas dentro das melhores condições e expectativas do serviço.

\section{Art. $9^{\circ}$ Compete à Equipe de Obstetrícia:}

I. Fazer o atendimento obstétrico antes do parto para avaliar as condições clínicas, laboratoriais, preparando a gestante para o parto no HCor.

II. Agendar e comunicar a data do parto.

III. Fazer o puerpério imediato e resolver as possíveis complicações pósparto.

IV. Participar das reuniões mensais da equipe multidisciplinar da Unidade Fetal,

V. Fazer pelo menos uma consulta após a alta hospitalar para retirada de pontos e reavaliação médica pós-parto.

VI. Acompanhar os procedimentos fetais junto com a equipe de medicina fetal e fazer a avaliação obstétrica após o procedimento até a alta hospitalar. 
VII. Ficar de plantão à distância toda vez que houver uma gestante internada no Hospital.

VIII. Solicitar ao coordenador do serviço melhorias, equipamentos e recursos para que o atendimento oferecido seja sempre atualizado e seguro.

IX. Registrar em prontuário todo e qualquer atendimento realizado.

\section{Art. $10^{\circ}$ Compete à Equipe de Neonatologia:}

I. Preparar o material necessário para o atendimento ao $\mathrm{RN}$ em sala de parto.

II. Discutir com o Obstetra os fatores de risco preexistentes em relação à cardiopatia congênita e a outros fatores pré-natais existentes.

III. Fazer o atendimento da sala de parto.

\section{Art. $4^{\circ}$ Compete à Equipe de Nutrição:}

I. Identificar as gestantes sob risco nutricional e que necessitam de avaliação e acompanhamento nutricional (baixo peso, sobrepeso, obesidade, inapetência persistente, diabetes e/ou hipertensão pregressa à gestação ou diabetes gestacional e/ou doença hipertensiva específica da gestação).

II. Avaliar as gestantes quanto às suas necessidades nutricionais, corrigir possíveis deficiências e propiciar adequado ganho ponderal de acordo com a idade gestacional.

III. Realizar a orientação nutricional adequada para cada caso;

IV. Acompanhar a evolução do estado nutricional e reavaliar de acordo com os critérios estabelecidos;

V. Proporcionar evolução adequada do estado nutricional da gestante, garantindo melhores resultados e qualidade de vida para a mãe e o recém-nascido;

VI. Registrar todos os atendimentos prestados em ficha específica e arquivar no serviço de Nutrição Clínica

VII. Realizar avaliação nutricional admissional do recém-nascido, estabelecer diagnóstico nutricional, nível de assistência e plano de cuidados nutricionais;

VIII. Realizar a prescrição dietoterápica baseada no estado nutricional e necessidades dos recém-nascidos;

IX. Garantir a oferta adequada de macro e micronutrientes;

X. Registrar em fichas de avaliação admissional específicas da Nutrição Clínica;

XI. Indicar terapia nutricional quando houver risco nutricional ou déficit nutricional

XII. Monitorar a resposta à terapia nutricional;

XIII. Acompanhar a evolução do estado nutricional e reavaliar de acordo com os critérios estabelecidos, proporcionando evolução adequada;

XIV. Registrar em ficha de evolução multiprofissional os atendimentos realizados

XV. Participar das visitas médicas, de grupos de discussão multidisciplinar, auditorias internas e desenvolver artigos e trabalhos científicos; 
XVI. Participar das reuniões mensais da equipe multidisciplinar da Unidade Fetal, contribuindo para o melhor entendimento das necessidades da Unidade;

XVII. Informar à equipe da Unidade Fetal as condições nutricionais percebidas na gestante.

\section{Art. $12^{\circ}$ Compete à Equipe de Enfermagem:}

I. Realizar a entrevista pré-internação para esclarecimento de dúvidas e orientações da internação;

II. Prestar assistência de enfermagem à gestante, parturiente, puérpera e ao recém-nascido;

III. Capacitar a equipe de enfermagem para o atendimento à gestante, parturiente e puérpera;

IV. Manter adequada estrutura física, recursos humanos e materiais, para que assistência de enfermagem no centro cirúrgico seja integral e o processo anestésico e cirúrgico sejam realizados em condições ideais;

V. Preparar as salas para procedimentos cirúrgicos, observando rigorosamente os princípios de assepsia;

VI. Zelar pelas condições adequadas de funcionamento dos equipamentos e aparelhos das salas cirúrgicas;

VII. Receber a paciente e prestar os cuidados necessários até a recuperação da consciência e estabilização dos sinais vitais.

VIII. Encaminhar paciente para RPA ou unidade de origem após avaliação e alta assinada pelo anestesista;

IX. Proporcionar serviço de qualidade acessível e rápido atendendo em tempo hábil as necessidades das equipes cirúrgicas e na recepção do neonato.

$X$. Acolher a puérpera durante o período de internação, auxiliando nas necessidades por eles apresentadas.

XI. Proporcionar o aumento do vinculo na UTI neonatal da equipe com a puérpera a fim de transmitirmos mais confiança ao cuidado prestado.

XII. Estar sempre disponível para discutirmos melhorias do cuidado ao recém nascido junto as puérperas.

\section{Art. $13^{\circ}$ Compete à Equipe de Psicologia:}

I. Realizar a avaliação psicológica da gestante/casal, considerando as condições emocionais destes, no que diz respeito ao enfrentamento psíquico diante do diagnóstico de cardiopatia do feto;

II. Identificar histórico e/ou presença atual de transtornos emocionais que possam dificultar o enfrentamento da gestante, ou ainda necessitar de intervenções de outros profissionais da saúde mental;

III. Realizar o acompanhamento psicológico ambulatorial da gestante/casal, conforme necessidade e demanda percebidas na avaliação, até a data do parto, sendo definido com os pacientes a frequência dos atendimentos psicológicos, bem como data e horário;

IV. Registrar os atendimentos psicológicos e arquivar em prontuário ambulatorial;

V. Informar à equipe da Unidade Fetal as condições emocionais percebidas na gestante/casal; 
VI. Acompanhar a gestante durante o procedimento do parto, sendo tal conduta previamente acordada entre profissional e paciente, salvo as seguintes exceções: ausência de vínculo terapêutico, ausência de demanda e/ou recusa da paciente para tal acompanhamento;

VII. Prestar assistência psicológica à gestante/casal quando da internação para o parto, até sua alta.

VIII. Participar das reuniões mensais da equipe multidisciplinar da Unidade Fetal, contribuindo para o melhor entendimento das condições emocionais de cada gestante em acompanhamento, bem como outras necessidades da Unidade.

IX. Diante da alta do bebê em que se percebam dificuldades emocionais relacionadas aos cuidados maternos que deverão ser oferecidos no período pós-alta hospitalar, o psicólogo deverá oferecer/encaminhar para o ambulatório pós-alta.

X. Diante do óbito do bebê, oferecer/encaminhar para o ambulatório pósóbito.

XI. Os ambulatórios pós-alta e pós-óbito funcionarão da seguinte forma: atendimentos semanais, nos moldes de psicoterapia breve, ou seja, será escolhido um foco para o tratamento juntamente ao paciente, de acordo com a demanda e necessidade do caso e serão oferecidas de 12 a 16 sessões de psicoterapia. $\mathrm{Na}$ finalização deste período, havendo a necessidade de serem trabalhadas outras questões emocionais, o paciente será encaminhado para Serviço Externo.

\section{Art. $14^{\circ}$ Compete à Equipe de Fisioterapia:}

I. Prestar assistência fisioterapêutica da UTI à Unidade de Internação aos neonatos nascidos no Hcor e às respectivas mães (puérperas) de acordo com prescrição médica;

II. Prestar assistência respiratória de acordo com a avaliação do diagnostico fisioterapêutico;

III. Desenvolver o plano fisioterapêutico condizentes com a avaliação de perda funcional e respiratória, traçar metas terapêuticas e registrar nos impressos de avaliação de Capacidade Funcional;

IV. Registrar em prontuário a conduta realizada e o planejamento terapêutico;

V. Planejar e monitorar a compreensão das orientações dadas referentes aos cuidados prestados e/ou orientações durante todo o período de internação até a alta hospitalar;

VI. Desenvolver o plano fisioterapêutico para prevenção do ADNPM às crianças recém-nascidas no Hcor, de acordo com a avaliação do diagnostico fisioterapêutico e ou das necessidades clínicas da criança, respeitando as limitações impostas pela cardiopatia;

VII. Garantir a execução dos protocolos assistenciais destinados a esta população;

VIII. Planejar a terapia buscando o resultado com foco nas metas dos indicadores assistenciais específicos para esta população;

IX. Participar da visita médica, alinhando com o médico responsável pela unidade / plantão ou médico assistente as ações para o desenvolvimento do planejamento terapêutico condizentes com as necessidades identificadas; 
X. Garantir a execução do plano terapêutico proposto pelo médico responsável pala unidade e/ou plantão nas unidades fechadas e pelo médico assistente nas unidades abertas;

XI. Manter-se constantemente atualizado para garantia de assistência e da segurança dos pacientes.

XII. Participar das reuniões mensais da equipe multidisciplinar da Unidade Fetal;

\section{Art. $15^{\circ}$ Compete à Equipe de Serviço Social:}

I. Realizar avaliação social, instrumental utilizado pelo serviço social, que tem o objetivo de analisar os requisitos de acesso ao projeto pela filantropia, diagnosticar possíveis aspectos sociais, econômicos e culturais que possam vir a interferir no processo saúde-doença, e para desenvolvermos condutas de intervenção e/ou mediação que visem contribuir no período de internação da paciente e seu bebê.

II. Informar, por e-mail da Unidade Fetal, o parecer social, quanto a aprovação ou não do atendimento da gestante no Programa da Unidade Fetal.

III. Orientar a gestante e familiares sobre os trâmites de atendimento do Programa como: realização do parto com data pré-agendada, acompanhamento pela equipe multidisciplinar, além de orientar as rotinas do alojamento e alimentação para os acompanhantes das crianças internadas na UTI Pediátrica, uso da lavanderia, visitas, atividades ministradas pelo serviço social e reunião semanal com a equipe multidisciplinar.

IV. Orientar a paciente sobre seus direitos e deveres, capacitando-a para melhor utilizar os recursos disponíveis.

V. Entregar o Termo de Consentimento para que a gestante assine tomando ciência que caso ocorra antecipação do parto ela deverá procurar o seu Hospital de Referência, já de seu prévio conhecimento, conforme indicado pela Unidade Básica de Saúde a qual encontra-se vinculada através do Programa Mãe Paulistana.

VI. Acompanhar durante o período de internação a paciente de acordo com as suas necessidades sociais, por solicitação da equipe multiprofissional ou a critério do próprio profissional.

VII. Atender quando houver demanda as gestantes cadastradas no Programa pelo convênio médico e/ou particular.

VIII. Participar das reuniões mensais da equipe multidisciplinar da Unidade Fetal, contribuindo para o melhor entendimento das condições emocionais de cada gestante em acompanhamento, bem como outras necessidades da Unidade.

IX. Realizar os trâmites necessários em caso de óbito do bebê.

\section{Capítulo V - Do horário de funcionamento:}

\section{Art. $16^{\circ}$}

$\mathrm{O}$ atendimento ambulatorial funciona das $8 \mathrm{~h}$ às $18 \mathrm{~h}$ com agendamento prévio. 
Art. $17^{\circ}$

$O$ atendimento na unidade de internação segue normas, rotinas e procedimentos operacionais que orientam a admissão, avaliação préoperatória, prescrição, indicação cirúrgica, orientação para alta e continuidade do cuidado.

Art. $\mathbf{1 8}^{\circ}$

Sempre que houver uma gestante ou puérpera internada, haverá um obstetra de plantão à distância, acessível e disponível para o atendimento de intercorrências.

\section{Capitulo VI - Legislações que regem o exercício do Programa}

I. Lei 8.069, de 13 de Julho de 1990-Estatuto da Criança e do Adolescente Capítulo I - Do Direito a Vida e a Saúde. - Art. $8^{\circ}$ ao Art. $10^{\circ}$;

II. Lei 11.108 de sete de abril de 2005 - que garante às parturientes o direito à presença de acompanhante durante o trabalho de parto, parto e pósparto imediato, no âmbito do Sistema Único de Saúde - SUS, da rede própria ou conveniada e

III. Constituição Federal de 1988. 


\section{ANEXO 2 - PARECER CONSUBSTANCIADO DO CEP - HCor}

Plataforma Brasil - Ministério da Saúde

Hospital do Coração/ Associação do Sanatório Sírio - ASS

PROJETO DE PESQUISA

Título: A PERCEPÇÃO DE GESTANTES USUÁRIAS DE UM SERVIÇO DE CARDIOLOGIA E MEDICINA FETAL EM UM HOSPITAL FILANTRÓPICO: UMA ABORDAGEM ETNOGRÁFICA

Área Temática:

Pesquisador: Enilda Maria de Sousa Lara Versão: 2

Instituição: Hospital do Coração/ CAAE: 02298212.2.0000.0060

Associação do Sanatório Sírio

\section{PARECER CONSUBSTANCIADO DO CEP}

Número do Parecer: 27451

Data da Relatoria: 22/05/2012

\section{Apresentação do Projeto:}

Este é um projeto que visa estudar do ponto de vista qualitativo, a percepção que gestantes de bebês cardiopatas têm do atendimento que recebem da equipe multiprofissional.Verificar se 0 atendimento foi efetivo,se realmente trouxe acolhimento e configurou um atendimento baseado no cuidado integrado ao paciente.

\section{Objetivo da Pesquisa:}

O objetivo do estudo é compreender a experiência das gestantes usuárias de uma Unidade de Cardiologia Fetal acerca do atendimento recebido por ocasião do processo de nascimento de seus filhos.

\section{Avaliação dos Riscos e Benefícios:}

A priori não há nenhum risco envolvido neste trabalho uma vez que o foco será a percepção que a gestante teve da forma que recebeu o atendimento da equipe multiprofissional. Em relação ao benefício, poderse-a ter uma melhor noção da importância do atendimento focal destas pacientes e aquilo que é mais importante para elas no momento em questão. Com isto a qualidade do serviço prestado será aprimorado.

\section{Comentários e Considerações sobre a Pesquisa:}

Esta é uma pesquisa qualitativa, é um assunto inédito estudado aqui no nosso país até porque não existem muitos serviços que atendem gestantes de bebês com cardiopatia congênita. Pesquisas qualitativas fazem falta no contexto hospitalar.

\section{Considerações sobre os Termos de apresentação obrigatória:}

Projeto adequado. 
Situação do Parecer:

Aprovado

Necessita Apreciação da CONEP:

Não

SAO PAULO, 28 de Maio de 2012

Assinado por:

Alberto José da SIlva Duarte 
ANEXO 3 - PARECER CONSUBSTANCIADO DO CEP - USP

Plataforma Brasil - Ministério da Saúde

Escola de Enfermagem da Universidade de São Paulo - EEUSP

\section{PROJETO DE PESQUISA}

Título: A PERCEPÇÃO DE GESTANTES USUÁRIAS DE UM SERVIÇO DE CARDIOLOGIA E MEDICINA FETAL EM UM HOSPITAL FILANTRÓPICO: UMA ABORDAGEM ETNOGRÁFICA

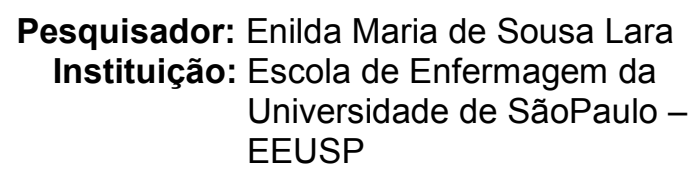

Versão: 1

CAAE: 01023812.5 .0000 .5392

PARECER CONSUBSTANCIADO DO CEP

\section{Número do Parecer: 5796}

Data da Relatoria: 13/03/2012

\section{Apresentação do Projeto:}

Trata-se de pesquisa qualitativa com abordagem na etnografia, para conhecer a percepção de participantes acerca de um serviço de saúde. O projeto apresenta a importância de se conhecer a satisfação dos usuários deserviços de saúde a partir de suas crenças, valores, necessidades e expectativas.

O projeto prevê a observação participante com a inserção da pesquisadora na instituição-cenário do estudo, o convívio e contato com as gestantes e mães da unidade cardiofetal e participação em reuniões da equipe interagindo com os atores envolvidos no atendimento prestado. Para o estudo qualitativo propõe quatro questões norteadoras.

\section{Objetivo da Pesquisa:}

Compreender a experiência das gestantes usuárias de uma unidade de Cardiologia Fetal acerca do atendimentorecebido por ocasião do processo de nascimento de seus filhos.

\section{Avaliação dos Riscos e Benefícios:}

Não são apresentados de forma clara quais são os riscos e benefícios das participantes na pesquisa.

\section{Comentários e Considerações sobre a Pesquisa:}

O projeto de pesquisa aborda tema relevante para a sociedade, pois propocionará conhecimento sobre $\mathrm{o}$ atendimento oferecido em determinada instituição de saúde.

Propõem uma abordagem etnográfica e qualitativa.

Algumas considerações necessitam de esclarecimentos:

1. como será realizada a análise qualitativa das entrevistas? Solicita-se aprofundamento do método proposto para análise de seus conteúdos.

2. A questão norteadora 2 sugere ambiguidade. $O$ que se espera avaliar com esta questão? 
3. serão coletados dados sociodemográficos e outras características dessas participantes?

isso seria interessante para melhor descrição do grupo estudado.

4. serão elegíveis como participantes da pesquisa qualquer gestante que procure atendimento na unidade de cardiologia fetal ou somente as que tiverem seus partos realizados nessa instituição? Considerar que o objetivo

inclui compreender o atendimento recebido por ocasião do nascimento, por isso entende-se que seriam somente as que tiverem o parto realizado nessa instituição. A sugestão é delinear melhor os critérios para convidar as participantes e esclarecer se somente as com diagnóstico de anormalidades serão entrevistadas ou se todas.

\section{Considerações sobre os Termos de apresentação obrigatória:}

Recomendações:

Solicita-se esclarecer as dúvidas apontadas nos comentários

\section{Conclusões ou Pendências e Lista de Inadequações:}

A pesquisadora respondeu a contento os questionamentos deste CEP.

\section{Situação do Parecer:}

Aprovado

Necessita Apreciação da CONEP:

Não

Considerações Finais a critério do CEP:

Este CEP considerou o projeto aprovado

, 09 de Março de 2012

Assinado por:

Celia Maria Sivalli Campos 